INTER NATIONAL MONETARY FUND
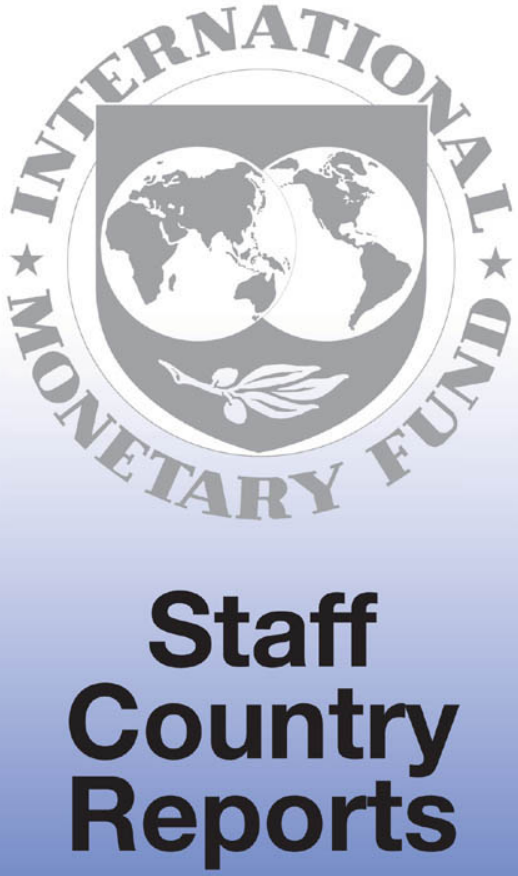
February 1996

IMF Staff Country Report No. 96/7

\section{Guinea-Background Paper}

This background paper on Guinea was prepared by a staff team of the International Monetary Fund as background documentation for the periodic consultation with this member country. As such, the views expressed in this document are those of the staff team and do not necessarily reflect the views of the Government of Guinea or the Executive Board of the IMF.

Copies of this report are available to the public from International Monetary Fund • Publication Services 700 19th Street, N.W. - Washington, D.C. 20431

Telephone: (202) 623-7430 - Telefax: (202) 623-7201

Telex (RCA): 248331 IMF UR

Internet: publications@imf.org

Price: $\$ 15.00$ \& copy

\section{International Monetary Fund \\ Washington, D.C.}


This page intentionally left blank

CInternational Monetary Fund. Not for Redistribution 


\section{INTERNATIONAL MONETARY FUND \\ GUINEA}

\section{Background Paper}

Prepared by a staff team consisting of Mr. M. Katz, Mr. A. Bessaha, Mrs. G. Devaux, Mr. T. Ehrbeck, and Mr. J. Ntamatungiro (all AFR)

\section{Approved by the African Department}

December 12, 1995

Contents

II. Output and Prices 2

1. Developments in output

2. Developments in inflation $\frac{2}{6}$

III. Fiscal Developments 6

1. Overview of recent fiscal developments

2. Revenue mobilization

3. Government expenditure

4. Debt service and financing operations 10

IV. Monetary and Financial Sector Developments

1. Introduction

2. Structure of the financial system

3. Recent monetary developments

4. The conduct of monetary policy 
V. External Sector Developments $\quad 22$

1. Developments in exports 24

2. Developments in imports, services, and private transfers

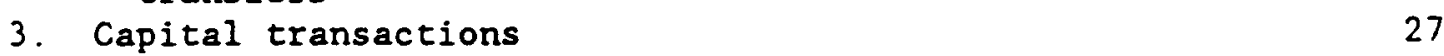

\begin{tabular}{ll}
4. Financing & 28 \\
\hline
\end{tabular}

5. Exchange rate developments 29

VI. Structural Reforms $\quad 30$

1. Public enterprises reform 30

2. Administrative reform 31

3. Reforms in the mining sector 31

4. Judicial reforms 32

\section{Text Tables}

1. Terms of Trade and Real Incomes, 1988-94 4

2. Gross Domestic Product at Constant Market Prices, $1988-94$

3. Government Revenue, 1987-94

4. Civil Service Wage Bill, $1987-94$

5. Current Expenditure on Other Goods and Services, 1989.94

6. Public Investment Program, 1988-94

7. Financing of Government Operations, 1988-94

8. Indicators of Financial Intermediation

9. Monetary Developments, $1988-94$

10. Nominal and Real Interest Rates, 1989-95

11. External Developments, 1988-94

12. Merchandise Exports, 1988-94

13. Merchandise Imports, 1988-94

1. Developments in Output 34

2. Developments in Prices

3. Fiscal Developments

4. Monetary Developments

\begin{tabular}{ll}
\hline 5. & Key Monetary Variables \\
\hline
\end{tabular}

6. External Developments 39

7 . horld Aluminum Prices and Bauxite and Alumina Export Prices

8. Exchange Rate Developments 
Annexes: Selected Topics

I. Government Revenue Diversification and Fiscal Adjustment 42

II. The Foreign Exchange Market $\quad 53$

III. External Debt Sustainability Analysis $r$

IV. The Public Enterprise Reform 65

Annex Tables

Annex I

1. Shares of Mining and Nonmining Revenue, 1986-94 43

2. Performance of the Customs Administration, 1989-94 47

3 . Domestic Taxation of the Nonmining Sector, 1989.94

Annex III

1. Key Indicators of External Indebtedness, 1995-2014

2. Analysis of the Sensitivity of the Balance

of Payments to Bawxite and Alumina Prices, Nonmining Exports, and Terms on New Borrowing, $1994-2014$

Annex IV

1. Overview of the Public Enterprise Sector

Before the Reform by Legal Statute

2. Results of the Divestiture Efforts, 1985-95 14

3. Legislation Adopted During 1990-95

4. Status of Public Enterprises Slated for

Reforms in the Context of the Second Phase, 1992-95

5. Overview of Public Enterprises Currently in 78 the State's Portfollo, July 1995

6. Sectoral Distribution of the Divestiture Efforts 80 by the Government, 1985-95

Charts

Al. Revenue and Fiscal Developments

B1. Exchange Rate Developments, 1994-September 95

Cl. Sensitivity of Debt Service Ratios to Bauxite, and Alumina Prices, Nonmining exports, and Terms of New Borrowing, 1994-2014 


\section{Appendices}

I. Summary of the Tax System

II. Statistical Tables

1. Gross Domestic Product at Current Market Prices, $1988-94$

2. Gross Domestic Product at Constant 1989 Market Prices, 1988-94

3. Savings and Investment Balances, 1988-94 90

4. Consumer Price Index, 1988-95

5. Consumer Price Index, 1988-95

6. Financial Operations of the Central Government, 1988-95

7. Central Government Revenue, 1988-94

8. Central Government Expenditure, 1988-94

9. Monetary Survey, 1990-95

10. Summary Account of the Central Bank, 1990-95

11. Summary Account of the Deposit Money Banks, 1990-95

12. Structure of Interest Rates, 1988-95

13. Balance of Payments, 1988-94

14. Composition of Exports, 1988-94

15. Composition of Imports, 1988-94

16. Balance of Payments of the Mining Companies, 1988-94 104

17. Direction of Trade--Exports, 1988-94

18. Direction of Trade--Imports, 1988-94

19. External Public Debt, 1988-94

20. External Debt Service, 1988-94

21. Debt Service Llabilities on Medium- and Long-Term External Public Debt, 1988-1998

22. Nominal Exchange Rates and Effective Exchange Rate Indices, 1988.95 
GUINEA - Basic Data $\underline{1} /$

Area, population, and GDP per capita

Area

Population (1994)

Total

Grownh rate

GDP per capila (1994)

Growh (change in percent)

Real GDP

Inflation (change in percent)

GDP dellator

Consumer prices (annual average)

Terms of trade (change in percent)

Central rovernment operations

Revenue and grants (change in percent)

Total expenditure (change in percent)

Overall budget balance, excluding

grants (in percent of GDP)

Net domeatic finabcing

(in percent of GDP)

Net exteroal finading

(in percent of GDP)

Money and credit (end-period; changes in percent)

Net foreign astets $2 y$

Net domeatic assets $2 /$

Public sector 2

Privale sector

Brosd money

External trensactions (in millions of U.S. dollars)

Exports 3/

Imports

Current accoust (excluding official transfers) $\underline{3}$ /

Overall balance

Current account (in percent of GDP) $3 /$

Includiag official transfer.

Excluding official transfers

Gross official reserves (end-period)

In millions of U.S. dollars

In months of total imports

External public debt (including IMF)

Debt outstanding (ead-period)

In millions of U.S. dollars

In percent of GDP

Scheduled debt service (in percent of export earnings) $\underline{3} /$

Of which: IMF

External artears outstanding (in millions of U.S. dollars; end-period)

Use of Fund resources (in millions of SDRs)

Guinean francs per U.S. dollar

(period average)

Effective exchange rates (period average,

changes in percent; depreciation -)

Nominal index

Real index
245.860 square kilometers

$\begin{aligned} 6.4 & \text { million } \\ 2.9 & \text { percent } \\ \$ 532 & \end{aligned}$

$1988 \quad \underline{1989} \quad \underline{1990} \quad \underline{1991} \quad \underline{1992} \quad \underline{1993} \quad \underline{1994}$

$\begin{array}{lllllll}6.3 & 4.0 & 4.3 & 2.4 & 3.0 & 4.7 & 4.0\end{array}$

$\begin{array}{lllllll}21.7 & 22.3 & 23.9 & 18.0 & 15.9 & 8.1 & 5.0\end{array}$

$\begin{array}{lllllll}27.4 & 28.3 & 19.4 & 19.6 & 16.6 & 7.1 & 4.1\end{array}$

$\begin{array}{lllllll}-10.9 & 10.3 & 1.7 & -6.0 & -12.2 & -6.1 & -4.9\end{array}$

$\begin{array}{lllllll}16.9 & 37.7 & 31.7 & 13.9 & 16.0 & -2.9 & -0.8\end{array}$

$\begin{array}{lllllll}34.4 & 25.7 & 31.9 & 12.4 & 10.9 & 1.4 & 0.2\end{array}$

$\begin{array}{lllllll}-10.0 & -8.7 & -8.8 & -8.2 & -7.8 & -7.5 & -7.2\end{array}$

$\begin{array}{lllllll}1.0 & -0.7 & -0.9 & 0.7 & -0.3 & -1.1 & 0.4\end{array}$

$\begin{array}{lllllll}5.2 & 5.8 & 4.1 & 3.3 & 7.4 & 4.9 & 2.6\end{array}$

$\begin{array}{lllllll}-15.0 & 13.9 & 37.6 & 14.4 & 15.1 & 19.0 & -12.7 \\ -33.8 & 1.9 & -10.3 & 20.4 & 8.3 & 3.9 & 9.3\end{array}$

$\begin{array}{rrrrrrr}33.8 & 1.9 & -10.3 & 20.4 & 8.3 & 3.9 & 9.3\end{array}$

$\begin{array}{lllllll}14.0 & -7.7 & -13.2 & 12.3 & 5.4 & -3.0 & 7.0\end{array}$

$\begin{array}{lllllll}78.4 & 19.1 & 34.8 & 11.7 & 30.6 & 10.5 & 25.0\end{array}$

$\begin{array}{lllllll}18.8 & 15.8 & 27.3 & 34.8 & 23.5 & 22.9 & -3.3\end{array}$

$\begin{array}{lllllll}609.1 & 731.1 & 816.7 & 790.2 & 656.8 & 665.0 & 625.9\end{array}$

$\begin{array}{lllllll}603.6 & 586.9 & 723.2 & 734.9 & 739.9 & 730.9 & 687.0\end{array}$

$\begin{array}{lllllll}-302.5 & -216.2 & -256.7 & -247.5 & -367.1 & -339.6 & -314.9\end{array}$

$\begin{array}{lllllll}-127.6 & -28.0 & -37.7 & -67.6 & -82.5 & -11.4 & -143.7\end{array}$

$\begin{array}{lllllll}-9.2 & -4.9 & -5.5 & -4.6 & -7.8 & -7.0 & -5.7\end{array}$

$\begin{array}{lllllll}-12.7 & -8.9 & -9.1 & -8.3 & -12.3 & -10.7 & -9.3\end{array}$

$\begin{array}{rrrrrrr}43.1 & 72.6 & 115.7 & 138.7 & 154.9 & 190.8 & 164.2\end{array}$

$\begin{array}{lllll}1.9 & 2.3 & 2.5 & 3.1 & 2.9\end{array}$

$\begin{array}{lllllll}2,074.7 & 2,024.5 & 2,123.5 & 2,400.5 & 2,474.7 & 2,593.5 & 2.809 .3\end{array}$

$\begin{array}{llllllll}87.0 & 832 & 75.3 & 80.5 & 832 & 81.7 & 82.8\end{array}$

$\begin{array}{lllllll}37.1 & 26.4 & 26.1 & 30.1 & 28.2 & 21.9 & 33.4\end{array}$

$\begin{array}{lllllll}(1.5) & (1.8) & (2.3) & (1.5) & (0.3) & (0.6) & (1.0)\end{array}$

$\begin{array}{lllllll}295.1 & 277.6 & 301.1 & 314.2 & - & 79.3 & 188.7\end{array}$

$\begin{array}{lllllll}474.4 & 591.6 & 660.2 & 753.9 & 902.0 & 955.9 & 976.7\end{array}$

$\begin{array}{lllllll}-5.7 & -6.7 & -3.5 & 0.6 & -7.7 & 11.9 & 11.0\end{array}$

$\begin{array}{lllllll}7.2 & 2.1 & -6.0 & 4.5 & -7.3 & 3.9 & -2.2\end{array}$

Exchange rate regime

1/ Including transactions with the former Soviet Union.

$2 /$ In percent of brosd money at the beginning of period.

3/ Exports were redefined to include expors of gold by the Central Bank, previousty recorded as "monetized gold" in the capital account. The current account deficit was revised accordingly. 
This page intentionally left blank

CInternational Monetary Fund. Not for Redistribution 


\section{Introduction}

Guinea is a relatively small, low-income sub-Saharan African country, situated on the west coast of Africa. It has a population estimated at 6.4 million, growing at an annual rate of 2.9 percent. Guinea has a tropical climate with heavy rainfalls during July-September, immense water resources that offer a major hydroelectric potential, large areas of arable land with vast agricultural potential, as well as a long sea coast that offers transportation facilities and a significant potential for a fishing industry. Besides agricultural resources, Guinea also has sizable gold and diamond deposits, high grade bauxite deposits that are among the largest in the world, as well as considerable--though so far unexploited--iron ore reserves. Guinea's bauxite reserves are estimated at 20 billion tons, or approximately one-third of world proven reserves, making Guinea the world leading exporter of bauxite, with a 40 percent share in world trade.

Following independence from France in 1958, for a quarter of a century, until 1984, Guinea was ruled under the centrally planned one-party regime of the First Republic. During this period, Guinea pursued policies under a command-economy system, with nearly all of the formal economy controlled by a large, and inefficient public sector, whose existence could only be sustained by the substantial royalties paid by foreign-operated mining companies in the bauxite subsector. The legacy of the First Republic had an adverse impact not only on economic performance and on the social infrastructure, but also changed the social culture profoundly and inhibited private sector initiative. $1 /$

Since 1985, Guinea has been undertaking an ambitious program of financial and structural reforms, designed to promote a sound development of its economic potential while reducing domestic and external imbalances, in the context of a market-oriented economic system. These reforms have included the liberalization of the exchange system; the overhauling of the public sector; the restructuring of the banking system and the introduction of market-based instruments of monetary control; the lifting of controls on prices and interest rates; the strengthening of government revenue from the nonmining sector; the enhancement of government expenditure control procedures; and the strengthening of the economic monitoring and management capacity. Guinea's adjustment and reform efforts have been supported by the Fund, and Guinea has received extensive financial and technical assistance from the World Bank and other donors, and substantial debt relief by Paris Club and other creditors.

Between 1986 and 1994, Guinea achieved sustained real GDP growth (averaging 4 percent per annum), a sharp reduction in annual average inflation from 65 percent to 4 percent, and notable progress in the area of structural reforms, but the country's performance in recent years has

1) For more details, see SM/93/129. 
been uneven, charecterized by repeated episodes of weaknesses in policy implementation. Guinea continues to be hampered by large domestic and external imbalances, as well as by structural, and Institutional constraints. The economy is highly dependent on the mining sector, which st11l accounts for about 80 percent of exports and about 30 percent of government revenue, making the country vilnerable to the vagaries of the world aluminum prices. Moreover, private sector development continues to be impeded by the legacy of the First Republic, namely a poor economic infrastructure, weak financial intermediation, an inadequate administrative and legal framework, and a high 1 lliteracy rate and limited entrepreneurial experience. Guinea's level of savings and investment remains extremely low, considering the daunting development needs of the country. I/ As a result, the level of unemployment remains high, particularly in urban areas, where ilving standards remain precarious for a significant portion of the population.

On the political front, a new constitution, based on a multiparty presidential system of government, was approved by referendum in December 1991. while the ban on the formation of political parties was lifted in April 1992. Free multiparty presidential elections were held on December 19, 1993 and the first multiparty parllamentary elections in Guinea's history were held on June 11, 1995. The Parliament was inaugurated on August 30, 1995.

\section{Qutput and Prices}

\section{Developments in output}

Guinea's relatively strong macroeconomic performance during 1987-94 allowed for an annual Increase in real per capita GDP of 1 percent. While Guinea's data base, particularly with regard to the real sector, remains weak, there are Indications that real GDP was boosted mainly by buoyant activity in trading activities, especially in the informal sector, and by a sustained recovery in agricultural production. On the basis of national

1 In Dhonte's Three Propositions on African Economic Growth (IMF Paper on Policy Analysis and Assessment, PPAA/95/9, June 1995), it is estimated that an investment ratio on the order of 29 percent would be necessary to accommodate the rapid labor force growth, relative to an actual ratio of 16 percent recorded by Guinea during 1986-94. 
account estimates, $1 /$ the growth of value added in the primary sector averaged about 3.7 percent annually during $1986-92$ before accelerating to. some 5 percent during 1993-94 (Table 1-2). The buoyancy in the primary sector reflected mainly a strong response of agriculture to economic liberalization and large investments in the agricultural sector. Marked increases in agricultural output generated higher incomes in rural areas, which in turn boosted activity in the rest of the economy, especially in the trade sector, which accounted for a large share of real GDP growth.

The large increase in agricultural output stemmed mainly from a strong rebound in the production of food grains (principally paddy rice), following a declining trend throughout most of the 1980s, and a sustained expansion in the production of vegetables (potatoes and onions) and fruits (pineapples). Guinea has also increased the production of exportable commodities, mainly coffee, cotton, and cocoa. At the same time, however, Guinea's food grain output is believed to be below potentlal, owing to inadequate technology utilized by farmers and a deficient transportation system; and rice imports remain high (over 280,000 tons in 1994). 2/ The performance of the mining sector as a whole was weak during 1988-94, with production increasing by only 1 percent a year on average, despite a marked expansion of small-scale mining activities in gold and diamonds during 1993-94. This poor performance reflects a low volume of production by bauxite mining companies in face of declining bauxite export prices and, to a lesser extent, the closure of the gold company (SAG) in 1992 and the diamond company (AREDOR) in 1994. Consequently, the share of large mining companies in real GDP declined substantially, from 22 percent in 1989 to 8 percent during 1994. However, reflecting the increasing role of small-scale mining activity, the decline in the share of the mining sector as a whole was less pronounced (from 22 percent in 1988 to 19 percent in 1994). Thus, the growth rate of nonmining real GDP averaged some 4.7 percent per annum during 1988-94 (Table 2 and Chart 1 ).

This growth performance was achieved despite a cumulative deterioration of 34 percent in the terms of trade during 1986-94, caused mainly by the sharp decline in bauxite and alumina export prices (Chart 2).

1 Extensive work was done in $1987-88$ to establish a solid base for national accounts, which resulted in the preparation of final data for 1986 and provisional data for 1987. Updated national accounts estimates for 1986-90 were provided to the staff in late 1993, covering mainly the sectoral composition of GDP, with limited information on expenditure aggregates. These data are subject to some methodological weaknesses, particularly with regard to the compilation of sectoral deflators and the estimates of activity in the informal sector. Provisional national accounts estimates for 1991-94 were also provided to the Fund by the Ministry of Planning and Cooperation in early 1995. Estimates should therefore be interpreted with caution.

2) Including imports for refugees from Liberia and Sierra Leone. 
These cumulative terms of trade losses are estimated to have lowered real national disposable income by about 6 percent in 1994 (Table 1 and Chart 2).

Iablo 1. Cuinea: Torne of Irade and Real Incomes, 1988-94

\begin{tabular}{|c|c|c|c|c|c|c|c|}
\hline & 1988 & 2989 & 1990 & 1991 & 1992 & 1993 & $\frac{2994}{\text { Est. }}$ \\
\hline & \multicolumn{7}{|c|}{ 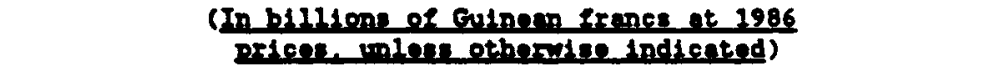 } \\
\hline 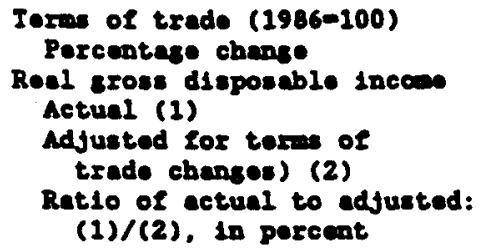 & $\begin{array}{c}79.8 \\
(-10.8) \\
694.2 \\
741.9 \\
93.6\end{array}$ & $\begin{array}{r}87.9 \\
(10.0) \\
713.0 \\
727.7 \\
98\end{array}$ & $\begin{array}{l}88.9 \\
(1.3) \\
747.3 \\
761.1 \\
98.2\end{array}$ & $\begin{array}{l}83.3 \\
(-6.3) \\
781.6 \\
804.9 \\
97.2\end{array}$ & $\begin{array}{c}73.7 \\
(-11.5) \\
815.4 \\
870.7 \\
93.6\end{array}$ & $\begin{array}{l}69.2 \\
(-6.1) \\
859.6 \\
929.4 \\
93.5\end{array}$ & $\begin{array}{l}65.9 \\
(-4.9) \\
899.4 \\
958.9 \\
93.8\end{array}$ \\
\hline
\end{tabular}

Source: Appeodlx II.

On the demand side, the real growth of both consumption and gross capital formation fluctuated sharply, reflecting shifts in government spending, as well as sizable changes in the mining companies' investment activity. During 1990, the Government increased its capital outlays; at the same time, mining companies undertook their rehabilitation investment program, which was completed in 1993. During 1993-94, to compensate for declining domestic revenue, the Government resorted to cuts both in current and investment spending. As a result, the growth of domestic demand slowed to about 3 percent in real terms.

The evolution of aggregate and sectoral savings-investment balances gives a qualitative indication of the performance achieved by the private sector and the Government in reducing domestic and external imbalances. Developments in savings were affected by declining terms of trade as well as the Government's fiscal stance. On average, gross national savings (excluding foreign grants) declined from about 8 percent of GDP during 1990-91 to less than 5 percent over the 1992-94 period. During 1990-92, gross investments were near 17 percent of GDP, reflecting mainly larger government and mining investments, before dropping to less than 14 percent in 1994. As a result, the net financlal balance (external current deficit) widened from a deficit of 9 percent in 1990 to 12 percent in 1992; the deficit improved gradually to an estimated 9 percent in 1994. Improvements in the net financlal deficits of the Government and the nonmining private sector only compensated for the reduction in the net financial surplus of mining companies. 
Iablo 2. Gulace: Gross Dowastic Froduct at Constant Market Prices, 1988-94

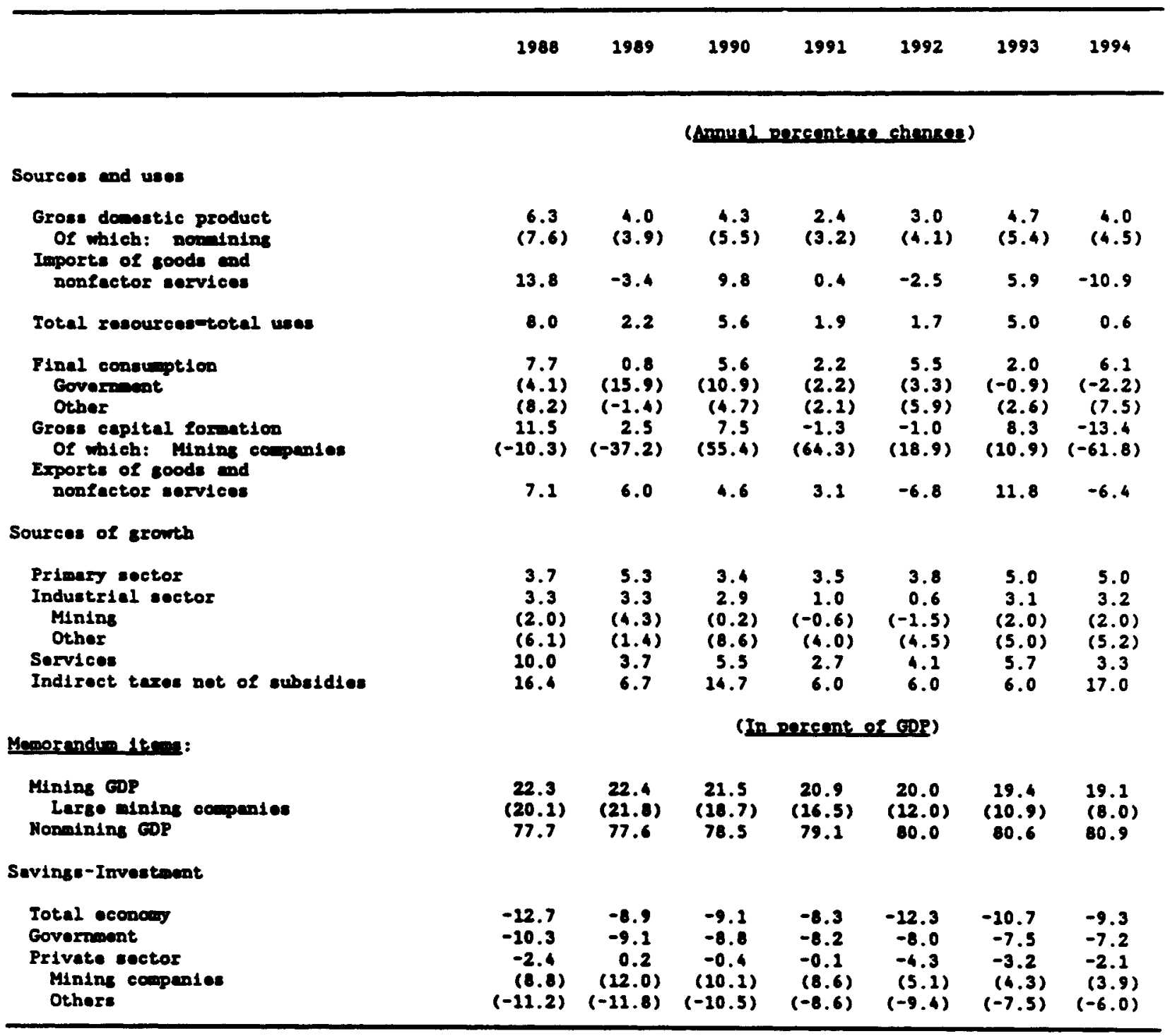

Source: Appeadix II.

During 1990-94, the Government recorded a negative financial balance; however, as ratio to GDP, this deficit was reduced progressively from 9 percent in 1990 to about 7 percent in 1994. The financial balance of mining companies was in surplus, although on a declining trend from 1989 (a reduction of 8 percentage points of GDP between 1989 and 1994), mirroring mainly declining bauxite and alumina export prices, as well as the increase in investments by large mining companies. Reflecting deep-rooted structural constraints, particularly in the formal sector, the rest of the private sector recorded deficits during 1990-94; however, a reduction in dissaving led to an improvement of its net financial balance by about 5 percentage points of GDP between 1990 and 1994. 


\section{Developments in inflation}

Guinea has made a significant steps in reducing inflation. The inflation rate, as measured by changes in the consumer price index for Conakry, came down from 65 percent in 1986 to 17 percent in 1992 and to 4 percent in 1994. The marked deceleration in inflation during 1986-1992 was largely the result of price and trade liberalization in the early stages of the reforms, the improvement in the supply of food and other consumer items that followed the initial surge prompted by the January 1986 devaluation, and the general tightening of the stance of macroeconomic policies. Inflation continued to decelerate during 1993-94, as a result of a tighter government fiscal stance, monetary policy reforms initiated in 1993 , as well as the stability of the exchange rate of the Guinean franc relative to the U.S. dollar. The 12 -monthly inflation rate declined from 16 percent at end-1992 to 2.2 percent by December 1994, despite a sharp rise in the price of imported rice during the last quarter of 1994. I Owing to expansionary fiscal and monetary policies during the first half of 1995, attributable in large part to the June parliamentary and municipal elections, the 12 -month Inflation accelerated to 5.9 percent through June, but decelerated to 3.7 percent in September 1995; a contributing factor was the sharp rise in the price of imported rice.

\section{Elscal Developments}

Significant progress has been made in recent years in the management of government finances. 2/ Since 1993, the central government budget has been comprehensive, as it covers transactions previously carried out by Kindia bauxite mining company (OBK/SBK), including defense outlays and expenditure related to road construction, in the context of a barter trade arrangement with the former Soviet Union (FSU). In addition, no more government transactions were financed directly by the mining companies. The occasional payments made directly by the bauxite company CBG on behalf of the Government during 1990-92, subject to subsequent servicing on marketrelated terms, were repaid during $1991-94$ through withholdings from tax payments due. To the extent that information was avallable or estimates could be made, extrabudgetary operations have been taken into account in the appendix tables on central government operations. $3 /$

\section{Overview of recent fiscal developments}

Recent fiscal developments have been marked by continued decline in mining sector revenue, and shortfalls in the collection of nonmining

1/. Rice, which is Guinea's staple food, has a weight of about 10 percent in the consumer price Index (CPI).

2) For further details, see SM/93/129.

3 In addition to the Central Government, there is the social security fund (CNSS), for which, however, no data are presently available. 
revenue, attributable mainly to recurrent weaknesses in tax and customs administration. Government revenue shortfalls were largely offset by persistent cuts in both current and capital expenditure (amounting to about 7 percent of GDP during 1990-94), to a degree that has often proved detrimental to the proper functioning of the administration and to long-term development. Moreover, notwlthstanding the progress made in recent years in strengthening expenditure control procedures, donestic government arrears were accumulated during 1991-94.

The overall budget deficit (on a comitment basis and excluding grants) narrowed gradually from 8.8 percent of GDP in 1990 to 7.2 percent in 1994. However, the continuous decline in government mining revenue from 10.6 percent of GDP in 1990 to a mere 3 percent in 1994 masks the positive results of the adjustment efforts undertaken by Guinea (Table 3 and Chart 3 ). The overall budget deficit, excluding mining sector revenue, fell from 19.5 percent of GDP in 1990 to an estimated 10.1 percent in 1994 , thus implying an adjustment effort equivalent to 9 percentage points of GDP, reflecting sharp cuts in government expenditure, and increases in nonmining revenue mobilization (from 5.2 percent of GDP in 1990 to 7.4 percent in 1994). I This performance, which was achieved while special provisions were required to cover the costs of the democratization process, corresponds to an adjustment performance in excess of 1 percentage point of GDP a year on average.

\section{Revenue mobilization $2 /$}

Reflecting the drop in mining revenue, total revenue declined in relation to GDP from about 16 percent in 1990 to slightly over 10 percent in 1994. Nonmining revenue grew steadily from 5.2 percent of GDP in 1990 to 7.4 percent in 1992, partially as a result of higher petroleum taxes and customs duties and improved revenue collection during 1991-92. The performance during 1993-94 was particularly poor, reflecting weaker tax and customs administration mainly during the run-up period to the presidential elections late in 1993; the shortfall in nonmining revenue during 1994 is attributable to a lower-than-expected level of taxable imports during 1994 , following the devaluation of the CFA franc in early 1994, as well as temporary lapses in tax administration owing to the long-awaited cabinet reshuffle of August 1994. This poor performance was exacerbated by a cumulative reduction by 3 percentage points in mining revenue during 1993-94.

1) Policies to increase nonmining revenue are discussed in greater detail in Annex $I$.

2/ Appendix I provides a summary of Guinea's tax system as of October 31 , 1995. 


\section{a. Mining sector revenue $1 /$}

Mining sector revenue declined considerably, from US\$251 million in 1987 ( 12.3 percent of GDP) to only US\$101 million in 1994 ( 3 percent of GDP), reflecting not only a worsening in the financial position of the major mining coupenies, but also OBK/SBK's dwindling surplus/taxes (Table 3). The drop in aining revenue was mainly a result of lower export prices for bauxite and alumine, following falling world prices for aluminum, to which they are linked. $2 /$

Tab10 3. Culnes: Covernaent Roverue, 1987-94

(In preant of ePR)

\begin{tabular}{|c|c|c|c|c|c|c|c|}
\hline & 1987 & 2989 & 1990 & 1991 & 1992 & 1993 & 2994 \\
\hline Totel revenue & 25.5 & 15.5 & 15.8 & 14.7 & 13.5 & 11.6 & 20.4 \\
\hline $\begin{array}{l}\text { Minins sector reveous } \\
\text { of which: abk/8tix }\end{array}$ & $\begin{array}{l}12.3 \\
(3.6)\end{array}$ & $\begin{array}{l}10.5 \\
(2.6)\end{array}$ & $\begin{array}{l}10.6 \\
(2.7)\end{array}$ & $\begin{array}{l}8.5 \\
(2.3)\end{array}$ & $\begin{array}{l}6.1 \\
(0.6)\end{array}$ & $\begin{array}{l}4.5 \\
(0.3)\end{array}$ & $\begin{array}{l}3.0 \\
(0.0)\end{array}$ \\
\hline Monminins sector revenue & 3.3 & 5.0 & 5.2 & 6.2 & 7.4 & 7.1 & 7.4 \\
\hline 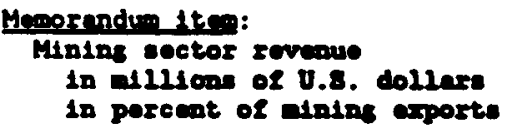 & $\begin{array}{r}250.5 \\
45.5\end{array}$ & $\begin{array}{r}254.7 \\
42.4\end{array}$ & $\begin{array}{r}299.3 \\
44.1\end{array}$ & $\begin{array}{r}252.0 \\
39.1\end{array}$ & $\begin{array}{r}200.4 \\
36.2\end{array}$ & $\begin{array}{r}143.8 \\
30.8\end{array}$ & $\begin{array}{r}100.8 \\
26.9\end{array}$ \\
\hline
\end{tabular}

Source: Appeadir II.

The fall in bauxite and alumina prices was compounded by declining prices for gold and dianonds, which also adversely affected the export taxes for these products, as well as the profitabllity of two other mixed mining companies (SAG, the gold company, and AREDOR, the diamond company, which closed down in mid-1992 and in early 1994. respectively). Moreover, FRIGUIA, the alumina company, underwent serious financial difficulties during 1993-94.

The diversification measures implemented since 1992 to promote diamond and gold exports have had a Iimited positive impact on Guinea's mining sector revenue; their contribution has remained relatively small, not only

1 For an overview of taxation arrangements in Guinea's mining sector until 1993, see SK/93/129. Appendix II.

2) Spot aluninu prices on the London Market Exchange reached a peak of over US\$3,500 per ton in June 1988, and remained generally above US\$2,000 throughout 1989, before declining to US\$1,640 per ton In 1990, US\$1,340 per ton In 1991, and US\$1,050 per ton by end-1993, before recovering to US\$1,476 per ton in 1994. 
because of veizeile conditions in goid and diamond markets but also becalise the nazure of these comnicdities makes tax evasion comparatively easy. Since 1994, the Government has inftiated a number of reforms that aim at raising over the medium term its tax receipts from bauxite and aluminum production. These reforms include (a) the renegotiation in 1994 with the foreign partners of the tax treatment (régime fiscal) of the largest bauxite mining company ( $C B G)$, allowing for a lower tax rate with a view to encouraging an expansion of output; $1 /$ and (b) the signing in early 1995 of a convention overhauling FRIGUIA's taxation. 2/ In addition, the restructuring plan for the Kindia Bauxite Company (SBK) was launched in April 1995 and is expected to be completed by end-June 1996, and renegotiation of a new convention with the Guinea Bauxite Company (CBG) is to be launched by end1995. At the same time, the Government has strengthened the control of exempted imports by major mining companies to avoid their diversion toward commercial uses.

\section{b. Nonmining revenue}

In view of the decline in mining revenue, and Guinea's narrow domestic tax base outside the mining sector, the Government intensified its efforts to mobilize revenue from the nonmining sector through a strengthening of tax and customs administration and a widening of the tax base. Nonmining sector revenue was multiplied by about four between 1988 and 1992 , implying an increase of about 3 percentage points of GDP, reflecting good performance in the collection of taxes on incomes and profits, domestic production and trade, and international trade. During 1993-94, a general worsening of this

1 The new tax system (1) implies an increase of production to $13.5 \mathrm{mil}$ lion tons by year 1999, entalling a new fiscal arrangement (from 1999 onward) whereby a uniform tax rate of 65 percent will be applied to the CBG's taxable income, under the assumption that the losses resulting from the modification of the tax system will be compensated by the projected increase in production; and (1i) establishes fiscal arrangements during the transitional perlod (1996-98), during which, other things being equal, tax losses will be smoothed over time (the Government will bear 50 percent of the losses in 1996; 75 percent in 1997-98; and 100 percent from 1999 onwards).

2) A new convention with FRIGUIA covering the period January 1995December 2009 was signed in February 1995. The Special Tax on Mining Products (TSPIS) previously paid by FRICUIA on exported alumina (US\$12.25 per metric ton) as an advance payment for the corporate tax and the dividend (65 percent) was replaced by a specific tax of US\$0.5 per ton on consumed bauxite (about US\$1.75 per ton of produced alumina) and by a corporate tax of 30 percent. FRIGUIA will also be subject to an annual lump-sum local tax. In addition, FRIGUIA is exempted from payment of the impot minimum forfaitaire, and imports related to the production of alumina are exempted (except for imports of fuel-oil, which are subject to a flat tariff of 5.6 percent). The convention will be reviewed every five years. 
performance was recorded, except in the collection of petroleum excise taxes (Appendix II, Table 7). I/

The increase in taxes on incomes and profits recorded during 1988-92 results mainly from higher withholding taxes on salaries and enhanced collection. The increase in corporate taxes recorded during 1994 reflects tax payment by a major commercial bank at the expiration of its concession, but also the increase in the minimum corporate tax impot minimum forfaitaire. Taxes on domestic production and trade increased at a rate almost twice that of GDP during 1988-94, as a result of measures to combat tax evasion and fraud related to petroleum products and increases in the excise tax rate on petroleum products (taxe spéciale sur les produits pétroliers--TSPP), as well as gradual upward adjustments in the turnover and sales tax rates.

Customs revenue (excluding TSPP) increased from GF 33 billion in 1989 to GF 112 billion in 1994, or more than 45 percent of nonmining revenue, reflecting developments in custow duties, which since 1988 have increased steadily on average by 34 percent per annum to about GF 51 billion in 1994. This performance reflects increases in customs duty rates during 1990-91, as well as major efforts directed at reducing exemptions, and strengthening customs administration to reduce tax evasion, through the imposition of severe penalties against customs agents found gullty of misappropriation, and the computerization of customs processing in Conakry in January 1993 and in Kamsar in April 1994. The increase in nontax and miscellaneous revenue recorded since 1990 has largely been accounted for by fishing rights and by the strengthening of the recovery of the debt service on credits on-lent to public enterprises. Dividends from public enterprises remain small, as none of these enterprises (outside the mining sector and the banking sector) enjoys significant profits and the collection of administrative receipts, including rental income from public properties, remains insignificant.

\section{Government expenditure}

In the context of Guinea's medium-term adjustment program, major emphasis has been placed on raising government development expenditure, both domestic- and foreign-financed, as well as on increasing budget allocations for priority social sectors, including health and education. This strategy was dictated by the need to rehabilitate and expand Guinea's basic economic infrastructure, which was largely neglected during the First Republic, to increase the provision of basic social services, particularly in the countryside, and to finance the denocratization process. In the event, while notable progress has been made in mobilizing external concessional assistance to finance the public investment program, the domestically financed development outlays (including the counterpart of externally financed investment projects) have often borne the brunt of expenditure cuts in the face of major revenue shortfalls. In addition, large increases in civil service salaries have necessitated cuts within other current spending,

1) For a detalls on developments in nonmining revenue, see Annex I. 
particularly in operating expenses and, to a lesser extent, in social expenditure as well.

\section{a. Wages and salaries}

Following the doubling of civil service salaries in 1991, no general salary increase was granted during 1992-94; across-the-board salary increases provided for under the budget were absorbed by new recruitment and promotions. During 1993, a number of new civil servants were hired irregularly, and unjustifled promotions were granted; the ratio of paid staff in higher grades ( $A$ and $B$ ) increased from 66 percent in 1992 to about 69 percent in 1993-94. After an abrupt increase in 1988; the total wage bill as a ratio to GDP remained relatively stable during 1988-94, representing on average 4.4 percent of GDP, though subject to a temporary upward fluctuation during 1991-92. Wages and salaries to the military are estimated to have represented on average 22-23 percent of the total wage bill (Table 4). 1/ Although wages and salaries declined in real terms during 1993-94, by 1994 the total wage bill had risen to the equivalent of 47 percent of current expenditure and 25 percent of total government expenditure, while absorbing 42 percent of total government revenue. In addition, this marked increase in the wage bill, at a moment when mining revenue was declining, accentuated the need to contain other expenditure categories, most notably outlays on goods and services and domestically financed investments, and led to inadequate allocations for the maintenance of public investments. However, civil service wages remained on average relatively low by regional standards (as evidenced by a low wage bill/GDP ratio, and a low ratio of average annual salary to per capita GDP).

\section{b. Subsidies and transfers}

Subsidies and transfers accounted for some 12 percent of current expenditure in 1994, and represented the equivalent of 1.1 percent of GDP (Appendix II, Table 8). Direct subsidies to enterprises were reduced in recent years to about 0.1 percent of GDP in 1994, reflecting measures to improve the financial position of enterprises such as the national airline (Air Guinee) and the restructuring of the public transportation company (SOGETRAG). However, this decline was broadly offset by increases in other transfer payments, including pensions and scholarships, and subsidies to hospitals, which were previously recorded under "other goods and services". Other transfer payments include increasing budget allocations to local entities, in the context of the decentralization policy, severance pay, as well as pensions. For many years, the annual growth in pensions has been lagging behind increases in civil service salaries. Although the financial impact of the rise in the pension rates in late 1991 and in 1992 was dampened by savings made by the computerization of pensions in 1992 , increases in pensions granted in late 1994 caused a major drain on public

1 Military wages represented about three fourths of total military expenditures during 1993-94 (Appendix II, Table 8). 
Ieblo 4. Culnea: Clvil service Wase 8111, 1987-94

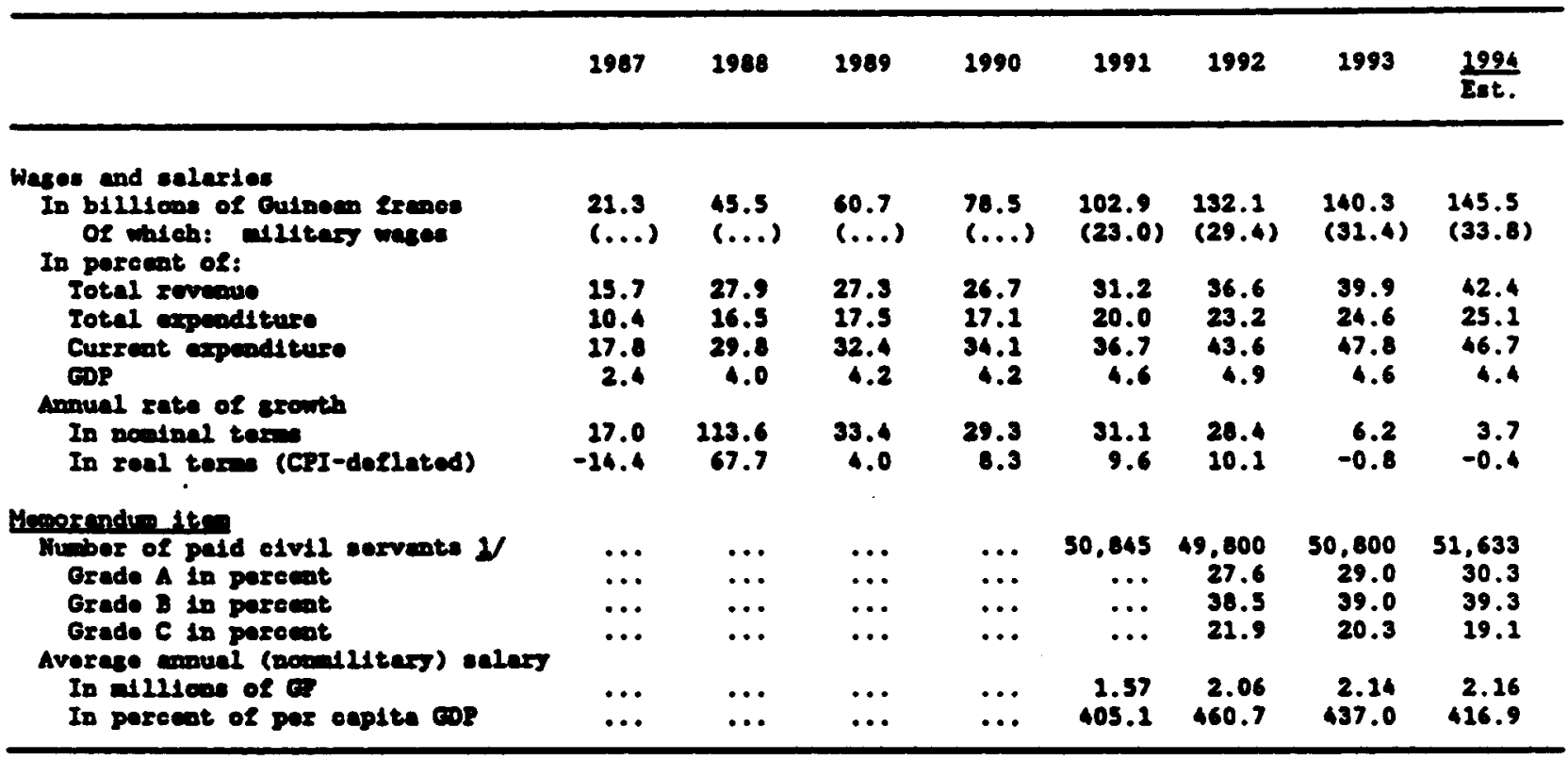

Sources: Appeodir II; and etafl estinates.

I Averese nuber of pald eiv1l servente, exeludins the alltery and temporers contractuel employees.

finances in 1994-95. Security problems in Liberia also increased pressures for Increases in Guinea's allitary operations during 1993-94. I However, military expenditure were reduced to below 2 percent of GDP during 1992-94.

\section{c. Other roods and services}

Expenditure on other goods and services accounted for some 25 percent of current expenditure In 1994, down fron 38 percent in 1990. Reflecting goverment difflculties, expendlture on other goods and services declined by the equivalent of 2.4 percentage points of GDP during 1991-94, or a cumulative 52 percent in real terms (Table 5). Th1s decline affected purchases of materials and supplies, including the consunption of petroleum products, but also to a lesser extent govermment expenditure on the social sectors (education, in particular). The persistent cuts in government expenditure became unsustainable and resulted in the accumulation of domestic arrears, including arrears to the water, electricity, and telecomminications companies; the reemergence of arrears had an adverse impact on econonic activity and on private sector confidence in the Government's ablilty to honor its financial comitments. These cuts were reinforced by the need to finance the democratization process, including

1 Contributions to the Military Force of Western African States in Liberia (ECOMOG) represented about 0.1 percent of GDP in 1994. 
provisions for the organization of elections, and new political bodies, such as the Supreme Court. 1/

Iab10 5. Buines: Current Exponditure on Other Coods and 8ervices, 1989-94

\begin{tabular}{|c|c|c|c|c|c|c|}
\hline & 1989 & 2990 & 1991 & 1992 & 1993 & $\frac{1994}{\text { Est. }}$ \\
\hline $\begin{array}{l}\text { Other soods and eervices } \\
\text { In billions of } G F \\
\text { In percent of GDP } \\
\text { In percent of total } \\
\text { current spondins }\end{array}$ & $\begin{array}{r}67.5 \\
4.7 \\
36.0\end{array}$ & $\begin{array}{r}06.7 \\
4.7 \\
37.7\end{array}$ & $\begin{array}{r}96.2 \\
4.3 \\
34.3\end{array}$ & $\begin{array}{r}89.4 \\
3.3 \\
29.5\end{array}$ & $\begin{array}{r}80.6 \\
2.7 \\
27.5\end{array}$ & $\begin{array}{r}76.5 \\
2.3 \\
24.5\end{array}$ \\
\hline $\begin{array}{l}\text { Annual rate of srowth in real } \\
\text { torme (CPI-dofleted) }\end{array}$ & 5.0 & 7.6 & -7.2 & -20.3 & -15.8 & -8.8 \\
\hline Mecorndy items & & & & & & \\
\hline $\begin{array}{l}\text { Nomwase ocial oxponditure (10 blllions of of ) } \\
\text { Educet1 on } \\
\text { Of wich: local investements }\end{array}$ & $(\ldots)$ & $\begin{array}{l}8.0 \\
(1.6)\end{array}$ & $\begin{array}{l}20.0 \\
(5.5)\end{array}$ & $\begin{array}{l}24.1 \\
(5.3)\end{array}$ & $\begin{array}{l}12.3 \\
(7.6)\end{array}$ & $\begin{array}{l}15.3 \\
(1.5)\end{array}$ \\
\hline $\begin{array}{l}\text { Bealth } \\
\text { Of which: locel inventenentes }\end{array}$ & $(\ldots)$ & $(1.6)$ & $\begin{array}{l}5.2 \\
(2.9)\end{array}$ & $\begin{array}{l}3.6 \\
(1.6)\end{array}$ & $\begin{array}{l}5.0 \\
(2.7)\end{array}$ & $\begin{array}{l}7.0 \\
(4.2)\end{array}$ \\
\hline
\end{tabular}

Source: Appendix II.

\section{d. Public investment program}

During 1990-94, the public investment program (PIP) declined by a total of over 4 percentage points of GDP, whlle the share of foreign assistance rose by 3.6 percentage points, to 85.6 percent of total PIP (Table 6). The share of forelgn grants in the PIP increased by 7 percentage points to 38 percent during this period. Most bllateral assistance is now provided in the form of project grants, and it also covers a large share of local costs (counterpart funds). Multilateral assistance is provided through long-term loans (over 75 percent of drawings) at highly concessional rates, but generally requires local contributions equivalent on average to about 15 percent of total project costs.

The share of the domestic development budget (BND) in government investment declined from 18 percent in 1990 to 14 percent on average during 1992-94, reflecting the sizable cuts in expenditure needed to contain the budget deficit in the face of declining revenues. This resulted in a

1 Domestically financed outlays for the organization of elections increased to GF 7.6 billion in 1993, up from GF 1.7 billion in 1992; in addition, direct assistance from donors, in the form of grants in kind, was estimated at GF 1.4 billion in 1992, and at GF 9 billion in 1993. 
shortage of adequate provisions for the local costs of many externally financed projects, which has delayed their implementation. Revenue shortfalls, together with administrative bottlenecks in project implementation, have contributed to the accumulation of domestic arrears. Moreover, adequate resources were not provided to cover recurrent costs. To address these issues, a joint ministerial order was signed in early 1995 by the Minister of Finance and the Minister of Planning and Cooperation, with a view to simplifying investment implementation.

Iablo 6. Gulnoa: Public Investment Procrea, 1988-94

\begin{tabular}{|c|c|c|c|c|c|c|c|}
\hline & 1988 & 1989 & 2990 & 1991 & 2992 & 1993 & $\frac{2924}{E x t .}$ \\
\hline $\begin{array}{l}\text { Totel FIF, in poroent of CDP } \\
\text { Dowestically Elnenced } \\
\text { Externally Elnenced }\end{array}$ & $\begin{array}{r}10.9 \\
9.1 \\
9.1\end{array}$ & $\begin{array}{r}11.1 \\
1.9 \\
9.2\end{array}$ & $\begin{array}{r}12.3 \\
2.2 \\
10.1\end{array}$ & $\begin{array}{r}10.4 \\
1.7 \\
8.7\end{array}$ & $\begin{array}{l}9.9 \\
3.2 \\
8.7\end{array}$ & $\begin{array}{l}9.4 \\
1.5 \\
7.9\end{array}$ & $\begin{array}{l}8.1 \\
1.2 \\
6.9\end{array}$ \\
\hline 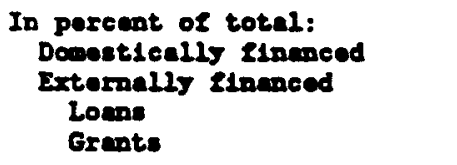 & $\begin{array}{c}17.1 \\
82.9 \\
(58.4) \\
(24.5)\end{array}$ & $\begin{array}{l}17.2 \\
82.8 \\
(54.3) \\
(28.5)\end{array}$ & $\begin{array}{c}18.0 \\
82.0 \\
(51.4) \\
(30.6)\end{array}$ & $\begin{array}{l}17.0 \\
83.0 \\
(32.1) \\
(30.9)\end{array}$ & $\begin{array}{c}11.9 \\
88.1 \\
(50.4) \\
(37.7)\end{array}$ & $\begin{array}{r}15.9 \\
84.1 \\
(50.3) \\
(33.8)\end{array}$ & $\begin{array}{l}14.4 \\
85.6 \\
(47.8) \\
(37.8)\end{array}$ \\
\hline
\end{tabular}

\section{Debt service and financine operations}

The debt service payments of the Central Govermment relate primarily to the servicing of Guinea's external public debt, as domestic public debt was virtually insignificant before 1993; it represented about 8 percent of the total in 1994. 1 Debt service obligetions increased by about 60 percent in nominal terms between 1990 and 1994, to GF 205 billion. However, as a ratio to GDP, the debt service burden declined from 7 percent in 1990 to 5 percent of GDP during 1993-94, mostly as a result of debt cancellations by bilateral creditors since the mid-1980s. 2/ The widening external imbalances and lower-than-expected Inflows of nonproject external assistance (related largely to delays in the implenentation of envisaged structural

1) The donestic debt service includes anortization on bonds issued in 1985, In the context of the Iiquidation of formerly state-owned banks, the amortization of other domestic supply credits, interest payments on treasury bills since 1993, and the anortization in Guinean francs of a debt buy-back operation concluded in 1992-93.

2. The increase in the external debt service and the accumulation of external payments arrears that occurred in 1994 reflect in part the takeover by the Government of the postal debt (US\$32.4 milifon) in the context of the privatization process of the telecommunications company, SOTELGUI. 
reforms) have generally inhiblted Gulnea from discharging its debt service obligations on schedule. I

The buildup of external payments arrears has permitted the Government to reduce its net borrowing from the domestic banking system. Since 1991, fiscal policy has been aimed at generating net repayments by the Government to the banking system, so as to allow for an adequate expansion in private sector credit, within a restrictive overall credit policy. The full attainment of this objective, however, has been frustrated by persistent fiscal slippages. Nonetheless, with the exception of 1991 and 1994 , government operations yielded net surpluses in domestic financing, even though at times there was a nonnegligible accumulation of domestic arrears. 2f The Government's overall surplus in terms of net domestic financing, however, was small relative to Guinea's recourse to exceptional external financing (Table 7). In addition to sizable disbursements of program assistance, external financing included substantial debt relief averaging about 3 percent of GDP during 1990-94, $3 /$ and a net accumulation of payments arrears.

Nonbank financing operations in 1992 and 1993 recorded large net payments of GF 20 billion and GF 16 billion, reflecting mainly the cost of liquidating the national petroleum company (ONAH/ASP) in 1992 (GF 21 billion) and the restructuring cost of the banking system in 1993 (GF 11 billion). Receipts from the sale of government assets were below GF 1 billion (Appendix II, Table 6).

\section{Monetary and Financial Sector Developments}

\section{Introduction}

Guinea's improved monetary management in recent years has brought about a substantial reduction in inflation, while real interest rates have become positive and the exchange rate of the Guinean franc has been stabilized at a broadly adequate level. However, progress in improving financial intermediation and banking efficiency has been considerably slower.

1 The accumulation of external debt service payments arrears on reschedulable debt in 1994 resulted from the postponement to January 25, 1995 of the Paris Club meeting on Guinea, originally scheduled for the last quarter of 1994.

2) The increase in net government bank financing during 1994 reflects a US\$12 million shortfall in external financing.

3/ Following the Paris Club rescheduling meetings of 1986, 1989, and 1992. 
Table 7. Gutbes: Plnenelns of Coverwent Oposations, 2988-94 $\mathcal{X}$

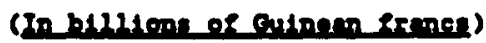

\begin{tabular}{|c|c|c|c|c|c|c|c|}
\hline & 1988 & 1989 & 2990 & 1991 & 1992 & 1993 & $\frac{1994}{\text { Eot. }}$ \\
\hline $\begin{array}{l}\text { Primery budset belmes } \\
\text { Less: debt eervice due } \\
\text { of which: donotic } \\
\text { overall belenes }\end{array}$ & $\begin{array}{r}24.6 \\
104.5 \\
-2 . .2)\end{array}$ & $\begin{array}{r}42.2 \\
108.7 \\
(\ldots . .3) \\
-16.5\end{array}$ & $\begin{array}{r}70.4 \\
130.2 \\
(\ldots . .2) \\
-52.1\end{array}$ & $\begin{array}{r}63.0 \\
170.5 \\
(\ldots 2.5) \\
-102.5\end{array}$ & $\begin{array}{r}72.4 \\
165.0 \\
(0.5) \\
-97.6\end{array}$ & $\begin{array}{l}54.0 \\
146.6 \\
(12.7) \\
-92.6\end{array}$ & $\begin{array}{r}45.2 \\
204.8 \\
(15.6) \\
-159.6 \\
\end{array}$ \\
\hline 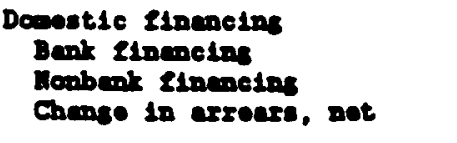 & $\begin{array}{r}11.8 \\
12.3 \\
-1.4 \\
1.0\end{array}$ & $\begin{array}{r}-4.7 \\
-8.0 \\
-1.5 \\
4.9\end{array}$ & $\begin{array}{r}-\frac{-8.9}{-16.2} \\
-0.9 \\
0.2\end{array}$ & $\begin{array}{l}15.6 \\
26.8 \\
-0.8 \\
-0.4\end{array}$ & $\begin{array}{l}\frac{-28.2}{12.0} \\
-20.2 \\
-20.0\end{array}$ & $\begin{array}{r}\frac{-27.4}{-7.6} \\
-15.6 \\
-4.2\end{array}$ & $\begin{array}{r}35.1 \\
21.4 \\
5.8 \\
7.9\end{array}$ \\
\hline 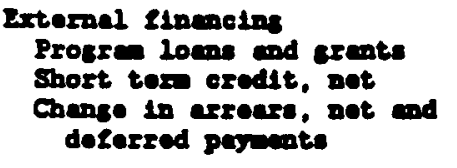 & $\frac{69.0}{28.7}$ & $\begin{array}{r}21.2 \\
44.2 \\
-17.0\end{array}$ & $\begin{array}{r}19.7 \\
0.9 \\
7.6 \\
60.3\end{array}$ & $\begin{array}{r}21.2 \\
34.8 \\
-0.9 \\
58.0\end{array}$ & $\begin{array}{r}120.8 \\
44.1 \\
-1.1 \\
-268.9\end{array}$ & $\begin{array}{r}120.0 \\
66.2 \\
-4.3 \\
1.8\end{array}$ & $\begin{array}{r}\frac{124.5}{23.5} \\
-5.7 \\
106.7\end{array}$ \\
\hline Dabt reller & 21.0 & 44.8 & -- & -- & 346.8 & 56.3 & - \\
\hline \multicolumn{8}{|l|}{ Hoopendun firm } \\
\hline $\begin{array}{l}\text { Debt relies } \\
\text { In percent of oOP } \\
\text { Debt service } \\
\text { In pereent of cop }\end{array}$ & $\begin{array}{l}(1.0) \\
9.2\end{array}$ & $\begin{array}{l}(3.1) \\
7.6\end{array}$ & $\begin{array}{l}(--) \\
7.0\end{array}$ & $\begin{array}{l}(--) \\
7.6\end{array}$ & $\begin{array}{c}(22.9) \\
0.2\end{array}$ & $\begin{array}{l}(1.9) \\
4.8\end{array}$ & $\begin{array}{l}(--) \\
6.2\end{array}$ \\
\hline
\end{tabular}

Source: Appendix II.

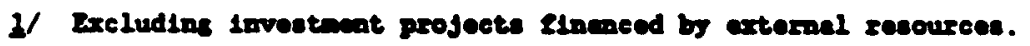

The monetization of the economy, as masured by the use of Guinean francs, renalned largely linited to the formal sector of the economy concentrated in urban areas. The ratio of broad money to nonmining GDP continued to fluctunte between 10 percent and 12 percent, a level signif1cantly below the average broad noney-to-GDP ratio of about 25 percent for sub-Saharan Africe (Table 8 and Chart 4). I Sinilarly, the ratio of currency to deposits, which can be interpreted as an indicator for the degree of confidence in the banking aysten, stayed at a substantially higher level than the average for sub-Saharan African countries, reflecting also the lack of a comerclal bank branch network in the interior of the country. At the same time, the use of foreign currency notes remained widespread, in particular in the informal trade sector.

1 Indicators based on nommining GDP (excluding value added by the large mining companies), rather than on total GDP, appear more relevant for analyzing developments of key monetary aggregates in Guinea, as mining companies operate largely as enclaves with main financial transactions taking place abroad and few linkages to the domestic economy. 
Gulaea: Iuble 8. Indicatore of Financtel Intereodiation $y$

(Ratios. in enrent)

\begin{tabular}{|c|c|c|c|}
\hline & Broad money/GDP & $\begin{array}{c}\text { Cleime on private } \\
\text { sector/COP }\end{array}$ & Currency/depostts \\
\hline Sub-Saharan Alrica & 25.2 & 14.9 & 41.1 \\
\hline Guinee $2 /$ & 10.8 & 5.0 & 103.3 \\
\hline
\end{tabular}

Sources: Internationel Pinanciel Stetistics, Econcalc Irends in Africa; staff celculation.

1 Dete for 1992, excopt Lor Cepe Vorde (1993), and Alzorie and 2embia (1991); the averege for sub-Sahere axcludes Ansole, Liberie, Mosmbique, Somalie, Seo Toab and Principe, and South Africe. 2) Uains normining COR.

In parallel with the limited use of Guinean francs, the extension of bank credit to the private sector remained subdued, representing on average about 5 percent of nonmining GDP in comparison with about 15 percent of GDP in sub-Saharan Africa. This low level of bank credit to the private sector reflects weaknesses in the financial infrastructure and the existence of a large number of nonrecoverable loans due to the lack of proper collateral and difficulties in the enforcement of financial contracts, associated with an inefficient judicial system. 1

In order to address the shortcomings of the financial system, the Central Bank of Guinea (Banque Centrale de la République de Guinée--BCRG) has introduced far-reaching monetary policy reforms since mid-1993. These reforms include the lifting of interest rate controls and the introduction of treasury bills with auction-determined yields, the adoption of a uniform system of reserve requirements, the reinforcement of bank supervision, the restructuring of two insolvent banks, the enactment of revised financial legislation, and the lowering of government participation in the capital of commercial banks.

\section{Structure of the financial system}

Accounting for more than 90 percent of financial assets, the six privately managed commercial banks that replaced the insolvent state-owned banks in 1985-86 dominate the formal financlal sector in Guinea. 2/ Their

1) At end-1994, nonperforming loans represented 17 percent of total bank credit to the private sector.

2) For details on government participation in the banking sector, see Annex IV, Table 5. 
ownership structure $18 \mathrm{mixed}$, with the Guinean Government participating in the capital of three banks. The three larger banks are linked to French commercial banks, one Islamic bank has a majority Saudi interest, and one of the smaller institutions is controlled by a group of Moroccan savings banks. Private Guinean investors hold interests in three of the commercial banks. Guinea's financial systen also includes four insurance companies, a social security institution (the Calsse Nationale de Securite Sociale--CNSS), and two small cooperative banks. Commercial banks operate essentially in Conakry, with a very limited number of branches outside the capital city. Additionally, an informal financial market has traditionally operated in Guinea and is estimated by some accounts--on the basis of activity in the gold, diamond, and informal trade sectors--to be roughly equal in size to the official system.

Following an initial period of rapid growth after the bank restructuring, both private sector credit expansion and deposit mobilization by commercial banks slowed down markedly in the beginning of the 1990s, as inadequate risk assessment in earlier lending decisions and limited internal controls led to the emergence of a sizable portfolio of nonperforming loans. Banks were forced to curtall their credit expansion, which, in turn, contributed to excess liquidity and a general reluctance to mobllize new deposits.

In reaction to the weaknesses in the commerclal banking sector, and with support from the World Bank and other donors, the Central Bank has since 1993 stepped up and restructured its regulatory efforts, concentrating banking supervision in a new department. In all comercials banks, senior management has been changed, credit-granting processes have been strengthened, and monitoring systens put in place. Several banks also established recovery units and began to make provisions against their nonperforming loans. The sizable increase in nonperforming loans during the first half of 1995 was largely due to reclassification and reflected mainly loans granted in the late 1980s. At the same time, banks were required to increase provisions against nonperforming loans (over 75 percent of bad loans were provisioned at end-September 1995). To strengthen commerclal banks, the Central Bank increased their minimum capital requirements in March 1995 from GF 500 million to GF 2 billion. Additionally, the restructuring and recapitalization of two weaker banks was completed in mid-1995. As a result, the viability of the comercial banking system has improved.

However, commercial banks in Guinea remain relatively small and rely on foreign exchange transactions and investments in foreign currency assets to generate incone. In their more traditlonal banking activities, they focus on short-term credit, which represented 85 percent of total credit at endJune 1995, with the bulk oriented toward trade financing. The concentration of bank lending in short-term credits reflects not only the structure of bank resources doninated by short-term deposits, but also the high risk associated with the financing of longer-term activities. Longer-term loans are extended only on the basis of avallability of donors' lines of credit or refinancing from BCRG. 
Kelying on substartial cionor finarcing, the two susll cucperative savings banks and a micro-finance progara operete in the interior of the country in an attempt to fill the gap left by the comercial banking systeri. These institutions have grown substantially since their inception, with both combined savings deposits and combined credit equaling about 6 percent of total deposits and total lending of commercial banks, respectively, at endDecember 1994. Although these institutions charge market-related interest rates, their interest and investment income does not fully cover operating costs, even after excluding financial costs and the salaries of donorsponsored expatriate staff. One institution, which is based on the traditlonal credit and savings cooperative model developed in Germany in the 19 th century, had grown by end -1994 to 45,000 members in 70 local branches. The second cooperative bank and the USAID-sponsored micro-finance program rely on Grameen-type social collateral. Their average loan size is about US\$150, more than 75 percent of borrowers are 111 iterate, and the average repayment rate is well above 95 percent.

\section{Recent monetary developments}

In recent years, the monetary authoritles have had only limited success in controlling the growth in money and credit aggregates, owing mainly to fiscal difficulties experienced by the Government. Despite a generally sluggish expansion in private sectcr credit, large overruns in government bank financing have often given rise to a higher-than-targeted expansion in the net domestic assets of the banking system, although net repayments were effected during 1989-90 and in 1993. I

Table 9. Gulnea: Monetery Developonte, 1988-94

(Annusi porcentase chenses: end-of-period dete)

\begin{tabular}{|c|c|c|c|c|c|c|c|}
\hline & 2988 & 1989 & 1990 & 1991 & 1992 & 1993 & 1994 \\
\hline Net foroigs. essots 11 & -15.0 & 13.9 & 37.6 & 24.4 & 15.1 & 29.1 & -12.7 \\
\hline Nict dowostic essets 1 & 33.8 & 1.9 & -10.3 & 20.4 & 6.3 & 3.9 & 9.3 \\
\hline $\begin{array}{l}\text { Nor public sector crodit } 1 / \\
\text { Private sector credit, excluding }\end{array}$ & 14.0 & -7.7 & -13.2 & 12.3 & 5.4 & -3.0 & 7.0 \\
\hline nonperformins loans & 54.0 & 22.2 & 34.1 & 14.3 & 35.0 & 27.1 & 12.2 \\
\hline Eroed money & 18.8 & 15.8 & 27.3 & 34.8 & 23.5 & 22.9 & -5.3 \\
\hline Cu=rency ourside benks & 28.6 & 24.5 & 22.1 & 40.9 & 11.4 & 25.2 & -7.1 \\
\hline
\end{tabular}

Scurce: Cantral Bank of Gsinas.

1: In pereent of broad woney at beginnins of period.

1) Government repayments to the banking system were accompanied by external debt relief or substantial accumulation of external payments arrears. 
The increases in net domestic assets have tended to be combined with better-than-targeted improvements in the net forelgn assets position of the Central Bank, achleved in large part through the accumulation of external government payments arrears and donestic purchases of gold by the Central Bank. As a result, until 1993, the growth of broad money was invariably higher than programied. Reflecting frequent changes in counterparts of broad money, broad money expansion fluctuated strongly during 1989-93, at rates ranging from 16 percent to 35 percent (Table 9 and Chart 4). Broad money declined by 3 percent during 1994, and velocity rose sharply. A major factor behind this decline in real money balances was the strong expectation of a correction of the exchange rate for the Guinean franc following the January 1994 devaluation of the CFA franc, which raised the demand for foreign exchange and led to a steeper-than-programmed decline in net foreign assets. The drop in net foreign assets was mirrored in the contraction in currency outside banks. Reflecting the increase in real interest rates to positive levels from July 1991 onward (Table 10 and Chart 4), and reforms in the financial sector, the importance of currency dininished somewhat, while the share of deposits within broad money grew to almost 50 percent at end1994, up from 42 percent at end-1991.

The Introduction of treasury b111s in June 1993 facilitated the lifting of interest rate controls. Since mid-1993, the refinancing rate has been set 3 points above the treasury bill rate, and central bank refinancing has been limited to on-lent donor lines of credit. At the same time, the controls on bank deposit and lending rates were lifted, except the minimum savings deposit rate and a maximum bank lending rate, which were set respectively 3 percentage points below and 12 percentage polnts above the treasury bill rate. With the gradual deceleration in inflation from mid1992, real rates of Interest rose to about 10 percent for savings deposits and about 25 percent for bank lending and remained relatively high despite the reduction in nominal interest rates from 1993.

\section{Conduct of monetary policy}

Monetary policy in Guinee is conducted within the framework of a small open economy with a flexible exchange rate allowed to absorb external monetary shocks. Broad money is the anchor for domestic prices, and policy aims at maintaining price stability and a sable exchange rate through appropriate domestic liquidity management. Given the state of the domestic banking system and the virtual absence of a money market, the monetary authorities had to rely during the first phase of structural adjustment on quantitative controls for the attainment of intermediate targets for broad money growth. At the operational level, however, the BCRG refrained from imposing credit ceilings on individual banks and resorted, when deemed necessary, to moral suasion. 
Table 10. Guines: Nominal and Reel Interest Rates, 1989-95

(In percent: ind-of-pertod dete)

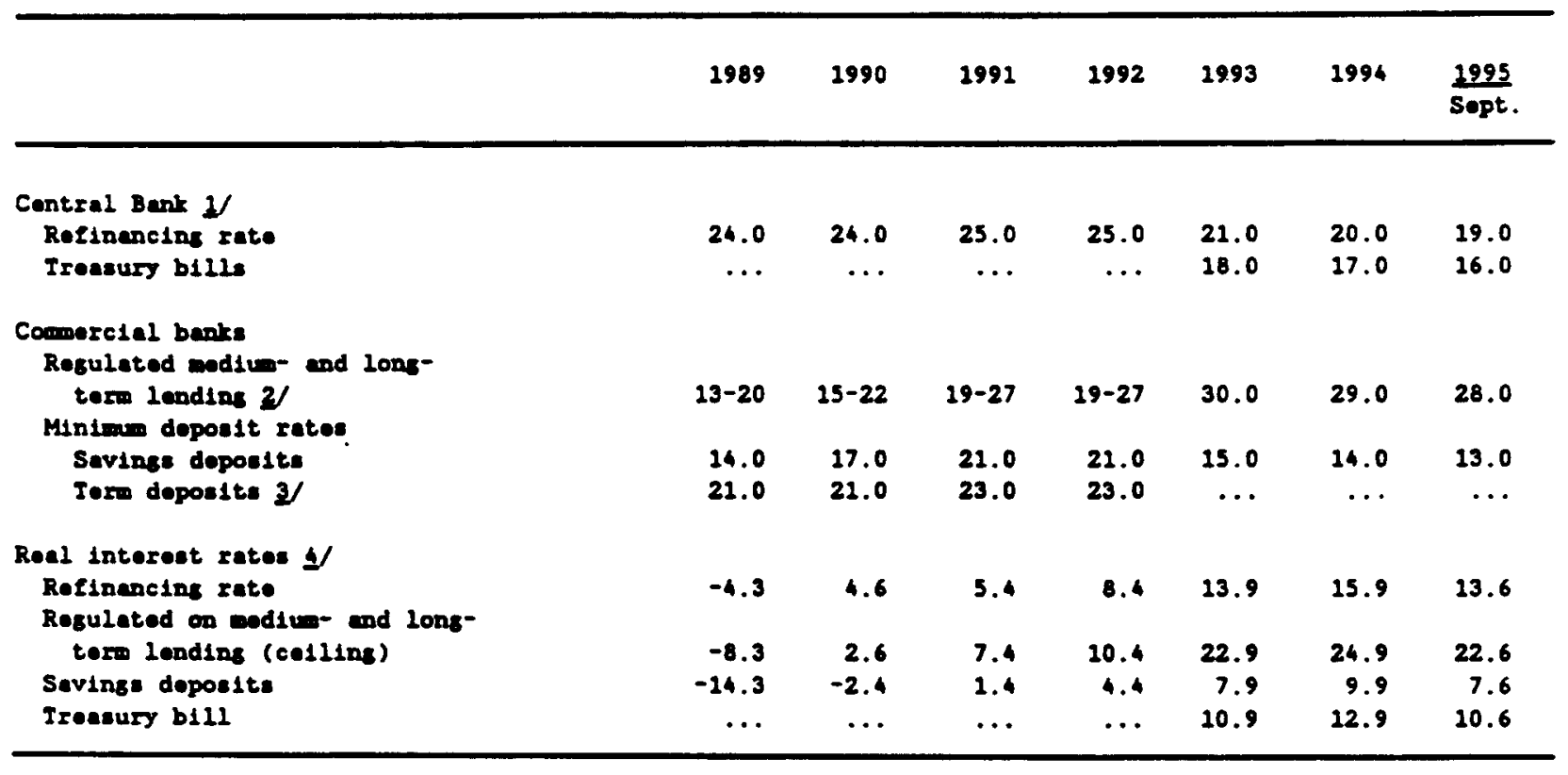

Sourea: Contral Bank of Cutbea.

1/ Effective September 15, 1993, centrel benk refinenclas was linited to on-1ent donor credite.

2f Until Jume 2993 lor leadins ellstble for preforcatial refinemeins; since then, ceilins.

3/ With a enturity of at least three conthe; subject to ainiene doposit of GP 3 aillion.

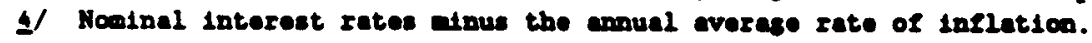

In June 1993, in the context of broader financial sector reform, the monetary authorities shifted to indirect instruments for liquidity control, while maintaining as transitional safeguard cellings at the aggregate level. Open market-type interventions, in which the Central Bank varies the net amount of treasury bills offered, have since been the principal instrument of monetary policy. Reserve requirements have been maintained mainly for prudential purposes, although their ratio has been changed three times since mid-1993.

After an Initial six-months period, during which treasury bills were sold on tap basis, the Central Bank started monthly auctions of 91-day treasury bills in December 1993. I Although these auctions are open to the nonbank public, participation has largely remained restricted to the commercial banks, which have been holding treasury bill stocks varying between 5 percent and 10 percent of broad money. By and large, the Central

1) The details are described in Instruction No. $68 / \mathrm{RCB} / 93$ of the BCRG. 
Bank was successful through 1994 in controlling the banking system's liquidity by adjusting the net issuance of treasury bills in open market-type interventions (Chart 5). This was not accompanied by sizable movements in nominal interest rates, however, which remained constant for long spells, largely owing to the lack of competition between banks. I In August 1995, the Central Bank moved to deepen the primary market by shifting to biweekly auctions and introducing 28-day treasury bills, aimed at facliltating comercial banks' liquidity management.

Reserve requirements--which were unified in May 1993 and were applied to all bank deposits--were initially set at a rate of 9 percent before being lowered to 7 percent in August 1993. After an initial perlod of leniency, in particuler with respect to the two weaker banks, the monetary authorities tightened the enforcement of reserve requirements in early 1995 and moved in August 1995 to shorter ten-day perlod during which reserve requirements have to be met, from the earlier one-month average period. On that occasion, the required reserve ratio was also increased by 1 percentage polnt, to 8 percent of total deposits; In late November 1995, the reserve ratio was raised back to 9 percent.

The recent progress in fostering treasury bill auctions and in stabllizing the financial sector should facllitate the intended full shift to indirect monetary policy based on reserve money programing. The money multiplier, which links reserve money to broad money, has remained relatively stable since June 1993, fluctuating within a band of roughly 2 standard deviations in elther direction from the average, although further financial sector reform and deepening of financial intermediation would imply a gradual increase. 2/ In 1995 the BCRG set up a macroeconomic unit to study, anong other things, the relationship between elements of the central bank balance sheet, broader monetary aggregates, and inflation, which ultimately is the policy objective. The choice of a controllable monetary aggregate as an intermediate target in the event of a shift to indirect monetary policy would depend on the findings of such empirical studies.

\section{v. External Sector Developments}

Reflecting the stagnation in the volume of mineral exports, a sharp decline in world aluminum prices, as well as weak world prices in recent years for coffee, cocos, and fish products, the external current account deficit (excluding official transfers) widened from 9.1 percent of GDP in

1. At end-September 1995, two banks accounted for 80 percent of the outstanding stock of treasury bills.

$2 /$ Assuming a normal distribution, one would expect 95 percent of observations in sample drawing to be found within 1.96 standard deviations from the mean value. 
1990 to 12.3 percent in 1992, before narrowing to an estimated 9.3 percent in 1994 (Table 11 and Chart 6). Despite inflows of official grants and concessional long-term loans equivalent on average to 10 percent of GDP a year, the overali balance of payments has been in deficit since 1986. These deficits, together with an increase in gross official reserves from a very low level at end-1986 to the equivalent of nearly three months of imports at end-1994, were financed in large part by debt relief from Paris Club and other creditors, the net accumulation of external debt payments arrears, and in part through the use of Fund resources. I Guinea's external public debt, while rising steadily in absolute terms, fell as a ratio to GDP from 87 percent at end-1988 to 75 percent at end-1990, but rose again to an estimated 83 percent by end-1994. 2/ The scheduled debt service as a ratio to export earnings was reduced sharply in 1989 , and has since remained broadly stable at 28 percent on average, though subject to year-to-year fluctuations.

Iable 12. Guinea: External Dovelopents, 1988-94

(In percent of CDP, unlese otherwise indicated)

\begin{tabular}{|c|c|c|c|c|c|c|c|}
\hline & 1988 & 1989 & 1990 & 1991 & 1992 & 1993 & $\frac{1994}{\text { Est. }}$ \\
\hline 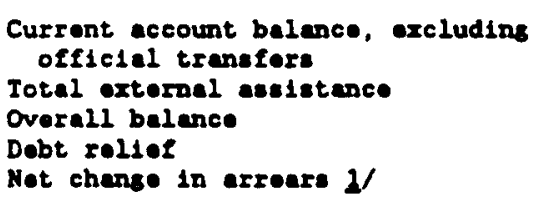 & $\begin{array}{r}-12.7 \\
11.6 \\
-5.4 \\
1.0 \\
3.3\end{array}$ & $\begin{array}{r}-8.9 \\
12.8 \\
-1.2 \\
3.2 \\
-1.1\end{array}$ & $\begin{array}{r}-9.1 \\
10.1 \\
-1.3 \\
2.1 \\
1.0\end{array}$ & $\begin{array}{r}-8.3 \\
10.6 \\
-2.3 \\
2.6 \\
0.3\end{array}$ & $\begin{array}{r}-12.3 \\
11.0 \\
-2.8 \\
12.9 \\
-20.0\end{array}$ & $\begin{array}{r}-10.7 \\
10.1 \\
-0.4 \\
1.9 \\
0.1\end{array}$ & $\begin{array}{r}-9.3 \\
7.6 \\
-4.2 \\
-- \\
3.2\end{array}$ \\
\hline $\begin{array}{l}\text { Groas officiel reasves, in } \\
\text { months of total imports }\end{array}$ & 0.9 & 1.5 & 1.9 & 2.3 & 2.5 & 3.1 & 2.9 \\
\hline $\begin{array}{l}\text { Externel public dobt } 2 / \\
\text { Debt envice ratio (1n } \\
\text { percent of exports of coods) }\end{array}$ & $\begin{array}{l}87.0 \\
37.1\end{array}$ & $\begin{array}{l}83.2 \\
26.4\end{array}$ & $\begin{array}{l}75.3 \\
26.1\end{array}$ & $\begin{array}{l}80.5 \\
30.1\end{array}$ & $\begin{array}{l}83.2 \\
28.2\end{array}$ & $\begin{array}{l}81.7 \\
21.6\end{array}$ & $\begin{array}{l}82.8 \\
33.4\end{array}$ \\
\hline
\end{tabular}

Source: Appondix II.

$1 /$ Includins deforred paysonts.

$\underline{2}$ End of pertod.

1 During 1994, there was an accumulation of debt service payments arrears on reschedulable debt, as the Paris Club meeting on Guinea, originally scheduled for the last quarter of 1994, was not held until January 25, 1995.

2) The increases in the external debt, the debt service, the overall external balance, and the accumulation of external payments arrears that occurred in 1994 reflect in part the takeover by the Government of the postal debt (US\$32.4 million), as noted in Section III. 4 above. 


\section{Developments in exports}

Despite the rapid growth of nonmineral exports, which responded positively to the improved policy environment, Guinea's external sector remains heavily dependent on mining exports, which on average accounted for about 90 percent of total export earnings during 1990-94 (Table 12). Within mineral exporta, the share of exports from small-scale mining activities (mainly gold and diamonds) has been increasing, but it accounted for only about 25 percent of mining exports in 1994. The mining sector remains largely dominated by foreign-operated bauxite and alumina producing companies, which represented about 60 percent of total exports in 1994 . The steady growth of the share of nonmining exports in total exports, from an estimated 7.5 percent in 1990 to 20.4 percent in 1994 , reflected in part the rapid growth of nonmineral exports, albelt from a low base, and primarily the fall in exports by major mining companies by 13 percentage points of GDP during 1990-94. This decline is explained by a stagnation in the volume of bauxite and alumina exports, the closure of two gold and diamond companies, as well as a sharp decline in world aluminum prices, to which Guinea's bauxite and alumina export prices are linked (Chart 7).

Teblo 12. Gulnos: Morchendise Exports, 1988-94

\begin{tabular}{|c|c|c|c|c|c|c|c|}
\hline & 1988 & 1989 & 1990 & 1991 & 1992 & 1993 & $\frac{1994}{\text { Est. }}$ \\
\hline $\begin{array}{l}\text { Exports/CDP } \\
\text { of whlch: minlas compendes }\end{array}$ & $\begin{array}{c}25.5 \\
(21.0)\end{array}$ & $\begin{array}{l}30.1 \\
(25.3)\end{array}$ & $\begin{array}{l}29.0 \\
(24.2)\end{array}$ & $\begin{array}{c}26.5 \\
(21.6)\end{array}$ & $\begin{array}{c}22.1 \\
(16.8)\end{array}$ & $\begin{array}{l}20.9 \\
(14.7)\end{array}$ & $\begin{array}{l}18.4 \\
(11.0)\end{array}$ \\
\hline $\begin{array}{l}\text { Change in export volum } \\
\text { of which: Dominins exports } \\
\text { ainins companies } \\
\text { In percent of totel: }\end{array}$ & $\begin{array}{r}3.6 \\
(74.6) \\
(0.7)\end{array}$ & $\begin{array}{r}7.8 \\
(69.2) \\
(6.4)\end{array}$ & $\begin{array}{l}1.6 \\
(31.0) \\
(-4.0)\end{array}$ & $\begin{array}{r}2.4 \\
(29.1) \\
(-0.6)\end{array}$ & $\begin{array}{l}-8.7 \\
(25.6) \\
(-13.0)\end{array}$ & $\begin{array}{l}14.3 \\
(17.1) \\
(10.5)\end{array}$ & $\begin{array}{c}-6.6 \\
(10.9) \\
(-13.5)\end{array}$ \\
\hline $\begin{array}{l}\text { Minins coupenies } \\
\text { Other alnins exports } y \\
\text { Moneinins }\end{array}$ & $\begin{array}{r}82.2 \\
12.0 \\
5.9\end{array}$ & $\begin{array}{r}84.1 \\
6.5 \\
7.4\end{array}$ & $\begin{array}{r}83.1 \\
9.5 \\
7.5\end{array}$ & $\begin{array}{r}81.5 \\
9.5 \\
9.0\end{array}$ & $\begin{array}{l}75.9 \\
12.0 \\
12.1\end{array}$ & $\begin{array}{l}70.1 \\
26.3 \\
13.6\end{array}$ & $\begin{array}{l}59.9 \\
19.8 \\
20.4\end{array}$ \\
\hline
\end{tabular}

Source: Appendix II.

1f Includins sold exports by the Central Bank of Culnea.

Although the level of its exports dropped substantially since 1990 , the Compagnie des Bauxite de Guinée (CBG) continues to play a dominant role. In 1994, CBG's exports amounted to US\$260 million, or more than 40 percent of Guinea's total exports. The high grade of bauxite mined in the Boke region (Sangarédi site) has made CBG one of the most profitable mining operations in the world, with a ratio of gross value added to output on the order of 70.75 percent. However, CBG's overall profitability has declined somewhat in recent years. In addition to falling prices during 1991-94, CBG faced technical difficulties stemming from recurrent fallures of the rallways line linking the mining site to the port and of the conveyor belts and grinding 
machines, as well as poorer quality deposits. During 1994, CBG's activities were disrupted by deteriorating conditions of the Pora River bridge at the Bidi-Koum site. These technical difficulties resulted in a stagnation in the annual bauxite output at about 11 million tons during 1990-94. Moreover, given the gradual exhaustion of the highest grade deposits at Sangared1, CBG has been forced to invest in the development of a new Iine at Bidi-Koum, with a lower aiumina content, whose exploitation started in 1992. I In 1994, about 80 percent of CBG's bauxite was produced at the Bidi-Koum site. CBG's profitability is expected to recover by 1999 , as capacity increases to 13.5 million tons annually, in accordance with the new tax agreement.

The alumina company, Friguia, also continues to be faced with low profitability related to a low production capacity and management problems, in addition to falling export prices. Friguia's production has recently plateaued at an annual output of some 640,000 tons (equivalent to a transformation of about 2.2 million tons of bauxite ore), which entails a very high cost per unit produced according to the industry standards. $2 /$ The company has launched a restructuring plan aimed at reducing its production cost; its profitability is expected to recover with the implementation of the new tax agreement, which aims at increasing aluminum production to over 1 million tons.

Following financial difficulties, the two other mixed mining companies--Soclété Aurifère de Guinée, or SAG (gold), and AREDOR (diamonds)--were forced to discontinue their activities in 1992 and 1994, respectively. These companies accounted for over 7 percent of total exports in 1992.

The Kindia bauxite company (SBK) used to export its low grade bauxite in the context of a barter trade arrangement with the former Soviet Union, which was discontinued in 1992. Exports were halved to 1 million tons in 1992. After a short recovery to 2.4 million tons in 1993, SBK's exports declined to 1 million tons (for a value of about US\$12 million) in 1994 , or one-third of its production capacity. The company is facing financial difficulties, mainly because of the reduction in demand from its single customer, a Ukrainian company. 3 / With the implementation of

1/ The bauxite ore at Sangared contained 61 percent alumina, while the Bidi-Koum ore has an alumina content of 56-58 percent.

2) Friguia processes a lower grade of bauxite, with an alumina content of 40 percent. In 1994, its production cost was estimated at US\$185 per ton of alumina, or over 150 percent the competitors' production cost.

3/ Reflecting the monopsonic structure of the market, but also the low grade of SBK's bauxite (the ore is wet, with an alumina content of only 46 percent), SBK's export price represented less than 50 percent of that received by CBG in 1994 . 
restructuring plan that was adopted in April 1995, the level of exports is expected to be raised to $2-3$ million tons: 1

Small-scale mining is estimated to have expanded significantly in recent years, for both gold and diamonds, especlally with the setting up in 1992 of private buying agencies, authorized to purchase gems in foreign exchange. In 1994 , exports were estimated at 134,600 carats, for a total value of US\$40.2 million. As regards gold, a growing share of domestic output has been purchased by the Central Bank of Guinea (BCRG) since 1990, with prices set weekly based on the London market price of gold, to which a premium is added, refleciling the differential between the official exchange rate of the Guinean franc and the parallel market rate. In 1994 BCRG exported 5 tons of gold, for a value of US\$62.5 million, or three-fourths of total gold exports.

Responding to the improved policy environment, the volume of nonmineral exports grew on average by 18 percent a year during 1990-94, albeit from a very low base; nonmineral exports amounted to US\$127.4 million, or over 20 percent of total exports in 1994. These exports include mainly coffee, fish, cotton, and fruits and vegetables. There is still room to expand nonmining exports, particularly as regards agricultural products.

\section{Developments in imports, services, and private transfers}

Imports increased markedly during 1990-92, before declining during 1993-94; in 1994, they represented 20 percent of GDP, down from $24-26$ percent during 1990-92. Developwents in imports were influenced by the mining companies' investment activity, with the increase in imports recorded during 1990-92 reflecting the rehabilitation investment program by CBG and Friguia, which was completed in 1993. The composition of total imports has changed in favor of the private sector. The share of nonmining private imports increased from 45 percent in 1990 to 58 percent in 1994, in part as a result of the privatization of the petroleum sector. The share of public sector imports (including imports related to the PIP) declined progressively to 20-21 percent during 1991-94, down from 28 percent in 1989 (Table 13).

Guinea's services and transfers continued to record sizable deficits, of which interest payments due, as well as services and transfers by mining companies, accounted for about three-fourths. Other net private transfer outflows reflected mainly higher expenditure on travel.

1) For more details, see Annex IV dealing with reforms in the public enterprise sector. 
Tab10 13. Guinea: Marchend1ee Importe, 2980-94

\begin{tabular}{|c|c|c|c|c|c|c|c|}
\hline & 1988 & 1989 & 1990 & 1991 & 1992 & 2993 & $\frac{1994}{E s t .}$ \\
\hline Import: & & & & & & & \\
\hline $\begin{array}{l}\text { In millione of U.S. dollar: } \\
\text { In parcont of CDP }\end{array}$ & $\begin{array}{r}603.6 \\
25.3\end{array}$ & $\begin{array}{r}586.9 \\
24.1\end{array}$ & $\begin{array}{r}723.2 \\
25.7\end{array}$ & $\begin{array}{r}734.9 \\
24.6\end{array}$ & $\begin{array}{r}739.9 \\
24.9\end{array}$ & $\begin{array}{r}730.9 \\
23.0\end{array}$ & $\begin{array}{r}687.0 \\
20.2\end{array}$ \\
\hline $\begin{array}{l}\text { In percent of totel: } \\
\text { Public sector } \\
\text { Mining companies } \\
\text { Other private }\end{array}$ & $\begin{array}{l}26.5 \\
25.2 \\
48.4\end{array}$ & $\begin{array}{l}27.6 \\
23.9 \\
48.4\end{array}$ & $\begin{array}{l}23.2 \\
31.8 \\
44.9\end{array}$ & $\begin{array}{l}20.9 \\
34.9 \\
44.2\end{array}$ & $\begin{array}{l}20.6 \\
31.7 \\
47.7\end{array}$ & $\begin{array}{l}20.1 \\
29.8 \\
50.1\end{array}$ & $\begin{array}{l}20.1 \\
22.2 \\
57.7\end{array}$ \\
\hline
\end{tabular}

Source: Appondix II.

\section{Capital transactions}

\section{a. Inflows of loans and grants}

As indicated above, the public investment program expanded steadily in recent years, reaching US\$346 million in 1990 , before declining to US\$275 million in 1994, with over 80 percent financed through resources provided by donors. To alleviate the pressures on the balance of payments, an increasing portion of the PIP has been financed in the form of grants, and project loans have continued to be at highly concessional interest rates with long maturities. The Government generally has refrained from contracting new loans on nonconcessional terns.

Nonproject external assistance has fluctuated markedly since 1989, reflecting mainly delays in the implementation of donor-supported programs. From a peak of US\$82 million in 1989, nonproject loans and grants fell to only US\$17 million in 1990, but recovered to US\$69 million in 1993 before declining again to US\$24 million in 1994. Most of the 1989 disbursements reflected the release of the first tranche of the second structural adjustment credit (SAC II) provided by the World Bank, which also involved several cofinanciers. Owing to a weakening in economic performance, virtually no nonproject aid disbursements took place in 1990, except for a small amount that had remained to be disbursed under the first tranche of SAC II. Ald inflows resumed in 1991 under World Bank sectoral adjustment credits--including the first tranche of a private sector promotion credit (US\$50 million), and the education sector adjustment credit (US\$20 million) with cofinancing from donors--which were disbursed during 1991-93. The second tranche of SAC II was disbursed in 1992-93. During 1994, program assistance for the education sector was received from the World Bank, the European Union (EU), and the U.S. Agency for International Development (USAID). Capital inflows by the mining companies rose markedly during 1990-92, as a counterpart to the expansion of their investment plans, 
zeash:ing an estiwated US\$83 million in 1992, before declining to US\$25 million in 1994 . F fnancing fncluted loans from the African Development Bank to the CBG, and loans from the European Investment Bank and compensatory financing under SYSMIN by the EU to FRIGUIA.

\section{b. Debt and debt service 1}

As of end-1994, Gulnea's external public debt was estimated at US\$2.8 billion, equivalent to 83 percent of GDP. Multilateral debt (including the organizations of Arab countries) amounted to US\$1,338 million, or 48 percent of the total, up from 29 percent in 1986. Despite sizable debt reductions, notably in 1989 and 1992, Guinea's external debt service burden has remained relatively heavy. Total external debt service amounted to US $\$ 257$ million in 1994, equivaleint to 41 percent of export earnings, of which public debt service represented US\$209 million, or 33 percent of export earnings. The actual debt service ratio (including cash payments for arrears reduction) declined to about 16 percent, signiflcantly less than the scheduled ratio. While the mining companies continued to discharge their external liabilities in an orderly manner, the Government limited its debt service payments to the nonreschedulable portion of its external debt.

Until mid-1992, Guinea's debt service obligations to the former Soviet Union (FSU), denominated mainly in rubies, were settled in full through the export of bauxite under the bilateral trade arrangement. The arrangement specified that 56 percent of OBK's export proceeds were to be used for debt service, while the remaining 44 percent could be used to purchase goods and services from the FSU according to certain rules. However, the original debt agreements between Guinea and the FSU did not indicate an interest rate, nor did they establish a debt service payments schedule. Following the discontinuation of the barter trade in mid-1992 and the substantial depreciation of the ruble, the servicing of the debt owed to. the FSU was suspended, and Guinea intensified its efforts to reach understandings with the Russian authorities on the veluation and the rescheduling of its outstanding bilateral debt carried over from the FSU. No understanding has been reached yet. At end-1992, Guinea's debt to the FSU, provisionally estimated at US\$463 million at the accounting exchange rate of Rub 0.557 per U.S. dollar, was reported to be in arrears.

\section{Financins}

Guinea was granted debt reschedulings successively in 1986, 1989, 1992, and january 1995. Separate agreements for the rescheduling of external debt payments arrears were also reached with various non-Paris Club bilateral creditors in 1990-94, including China, Romania, and Egypt, and Morocco. However, Guinea continued to accumulate external payments arrears on

1) For a discussion on external debt sustainability, see Annex III. 
reschedulable external obligations, particularly during 1993-94. I In January 1995, Paris Club creditors agreed on a rescheduling on concessional Naples terms, entalling a 50 percent reduction in net present value terms of the outstanding stock of pre-cutoff date debt arrears at end-1994 and eligible debt service falling due in 1995. The total debt service rescheduled by Paris Club creditors, with which Guinea has concluded bilateral rescheduling agreements, amounts to about US\$182 million. Assuming comparable treatment by other creditors, the amount of debt relief provided by the rescheduling agreement is estimated at US\$253 million. Guinea is also in the process of normalizing its relations with commercial bank creditors. Preparations for a buy-back scheme, covering outstanding debt, are at an advanced stage and are expected to be concluded by mid-1996. The cost of this operation is projected to be financed by assistance from the World Bank, under the IDA debt reduction facility, with cofinancing from Japan.

As a result of the successive rescheduling agreements, the stock of previously rescheduled debt rose to 34 percent of Guinea's external public debt at end-1994. Given the growing share of debt owed to international organizations, this has resulted in a marked reduction in the share of debt eligible for rescheduling, to 11 percent of total external debt. $2 /$

The buildup in gross official reserves, from a low level of US\$24 milIIon at end-1986 to US\$159 million at end-1994, equivalent to about three months of total imports, was attributable in large part to the Central Bank's policy of domestic gold purchases. The share of gold holdings increased from 33 percent of gross official reserves at end-1990 to over 50 percent by end-1994.

\section{Exchange rate developments}

An interbank market for forelgn exchange was introduced at end-October 1994, In an effort to move away from the managed floating system that had been operated through weekly auctions organized by the Central Bank. $3 /$ Under the new system, the exchange rate of the Guinean franc is determined

1 Efforts are under way to reach understandings with countries to which Guinea has outstanding obligations under inoperative bilateral payments agreements. During 1992-93, Guinea concluded a buy-back deal on part of its debt owed to the former Yugoslavia, for the equivalent of US\$50 million, at a discount estinated at 60 percent. The debt servicing in Guinean francs finances the construction of a hydroelectric dam at the Milo River in Upper Guinea.

2) Reschedulable obligations include: (1) pre-cutoff-date Paris Club debt not yet rescheduled; (1i) the 1986 Paris Club debt rescheduling on nonconcessional terms; (1ii) debt owed to commercial banks and suppliers; and (iv) debt not yet rescheduled owed to non-Paris Club bllateral creditors.

3) For a discussion on the functioning of the interbank market, see Annex II. 
by the supply and demand for forelgn exchange between the authorized forelgn exchange dealers. The Central Bank, a net recipient of nonproject aid flows and mining company recelpes, also participates in the interbank market, as the major supplier of foreign exchange. Under this new system, between October 1994 and September 1995, the Guinean franc depreciated marginally (2.1 percent) in terms of the U.S. dollar. The spread between the interbank and the parallel market exchange rates widened initially from around

3-4 percent at end-October to 12 percent by end-1994, but narrowed slightly to about 10 percent in September 1995. In real effective terms, the Guinean franc declined by 12 percent from end-1993 to June 1995 (Chart 8).

The introduction of the interbank market for foreign exchange was preceded by a series of reforms in the exchange system, including: (a) a further liberalization of the activities of foreign exchange bureaus in 1993 (the Central Bank eliminated the mandatory deposit of GF 5 million by foreign exchange bureau and lifted the upper limit of US\$5,000 on sales of foreign exchange by foreign exchange bureau); and (b) on July 1, 1994, the full liberalization of (1) payments and transfers for current transactions with the lifting of the remaining minor restrictions on foreign travel and income transfers; and (1i) the opening of foreign currency deposits with local commerclal banks by residents, with a view to enhancing confidence in the Guinean franc. Finally, on November 17, 1995, Guinea notified the Fund its acceptance of the obligations under Article VIII, Sections 2,3, and 4 of the Fund's Articles of Agreement.

\section{Structural Reforms}

The program launched by the authorities in December 1985 envisaged wide-ranging structural reforms that would affect the entire spectrum of economic activity in Guinea. Major structural reforms undertaken during 1985-92 include: (1) the overhauling of the banking system; (ii) the restructuring of the public enterprise sector; and (i11) the reduction of the size of employment in the public sector from over 90,000 civil servants at end-1985 to 50,400 by end-1992. W During 1993-94, the Government stepped up structural reforms in the areas of public enterprises, civil service, the mining sector, and the judicial sector.

\section{Public enterprise reform}

Reforms in the sector of public enterprises included the privatization of the management of the electricity company (ENELGUI) in July 1994, and the preparations for the privatization of the telecommunications company (SOTELCUI). SOTELCUI was offered for sale ( 49 percent of the shares) to the

1 Detalls of structural reforms carried out before 1993 are presented in SM/93/129; reforms undertaken since 1993 in the financial sector are discussed in Section IV above; reforms in the public enterprise sector are discussed in Annex IV. 
private sector in September 1994; five offers had been recelved by end-April 1995, and the selection process of the buyer 18 to be completed by December 1995 prior to its privatization by end-March 1996. In contrast, the privatization of Air Guinee, which has been offered for sale since July 1994, is running behind schedule; to accelerate the process, a new audit to determine the net value of the company was completed in September 1995 prior to its sale to the private sector by end-March 1996. Also, the restructuring of the transportation company (SOGETRAG) was initiated in April 1994 with the downsizing of its activities, including a reduction of the employment by 400 , and the closure of unprofitable lines.

\section{Administrative reform}

In the area of administrative reforms, the Government pursued its program of reducing the size of the civil service with a view to raising remuneration rates in the civil service (nominal wages have been kept unchanged since October 1991) and improving Guinea's administrative capacity to implement economic reforms. In the event, the Government was not able to reduce the number of civil servants as planned. During 1993, there were major overruns in new hirings and the granting of promotions in the civil service, which increased the number of civil servants, excluding temporary contractual employees, to more than 52,000 at end-1993. In late 1993 and 1994, the Government took measures to correct these slippages and to control total employment in the civil service. Quantitative targets were set not only on the government wage bill, but also on the size of the civil service, and strengthened procedures for hiring and promotions in the civil service have been applied since Karch 1994, requiring the joint signatures of the Minister of Planning and Finance, and the Minister of Civil Service and Administrative Reform, as well as confirmation by the Director of the Budget that budgetary credits exist.

In July 1994, new organizatiomal and staffing plans were also established for most of the ministries. Consistent with the new staffing plans, the Government redeployed about 5,000 employees who had been identified in 1992 to be without clearly defined posts, resulting in an increase in the number of paid civil servants, excluding temporary contractual employees, to 53,743 by end-1994. At end-1994, the Ministry of Civil Service and Administrative Reform conducted a countrywide census of civil servants to register retirees and elininate "ghost" civil servants from the roster of the civil service (FGA). This permitted the reduction in the number of civil servants to 52,413 at end-June 1995, despite the increase in the number of ministries from 17 to 28 in August 1994.

\section{Reforms in the mining sector}

Reforms in the mining sector entailed the restructuring of the kindia bauxite mine (OBK), the adoption in late 1994 of a reinforced strategy for the mining sector, and the renegotiation of mining concessions with CBG and FRIGUIA. OBK was effectively converted from a government agency into an autonomous public enterprise (SBK) in early 1993, with the appointment of a 
managing director and a board of directors, and the complete separation of its financial operations from those of the Central Government. This move was necessitated by the discontinuation of the barter arrangenent with the FSU in mid-1992. OBK' financial operations, which were handled independently by Gulnea's Central Bank until early 1993, were also obscured by numerous transactions unrelated to bawrite mining. From 1993 onward, SBK is in principle subject to an explicit turnover tax, at a rate of 30 percent. However, the company's financial position has continued to be poor, which is related to the low quality of 1 ts bauxite, and to financial difficulties experienced by its single buyer. The restructuring plan for SBK was launched in April 1995 and is expected to be completed by end-June 1996.

The Government's development strategy for the mining sector has been strengthened, as reflected In the new Mining Code that was revised in June 1995, with a view to encouraging foreign direct investment in the bauxite, alumina, gold, and dianond subsectors. The new strategy entails minority government equity particlpation in now ventures as a forn of royalty, and the establishment of an enabling administrative and institutional environment, entaling the adoption of simplified tax provisions; as a result of these policies, several new gold and diamond mining companies have been set up and explorations have begun. Discussions are also under way with private investors who could take over AREDOR and reopen the diamond mine it previously exploited.

The Government has taken measures to restructure bauxite mining, which still accounts for the bulk of export earnings and a large part of government recelpts. In this context, the Government has initiated a number of tax reforms that aim at raising mining production and the mining sector's tax receipts over the medium term (see Section III.2.a, on mining revenue). Finally, to clarify relations between the Government and the mining companies, the Office d'aménagement de Boké (OFAB), previously in charge of the infrastructure used by Compagnie des Bauxites de Guiné (CBG), was restructured in early 1995 and transformed into national agency (Agence nationale d'aménagement des infrastructures minieres), responsible for designing infrastructural policies for the mining sector as a whole.

\section{Judiclal reforms}

The limited efficiency of the legal and judicial system in Guinea constitutes a major obstacle to private sector development. The legal impediments to private sector activity were discussed at a round table organized by the Government and the World Bank In October 1992, with part1cipation from representatives from the legal profession, the banking sector, and the business community. To remedy the deficiencies of the legal system and protect property rights, in 1992 the Government enacted Parts I and II of the Code on Economic Activity (dealing respectively with corporate and bankruptcy laws); Part III (financial aspects of economic activity) and Part IV (industrial ownership) were enacted in July 1994 and in June 1995, respectively. In addition, with a view to facilitating private sector access to bank loans while minimizing bank losses owing to lack of proper 
collateral and enforceable guarantees, a Land Tenure Code was established in March 1992, and a simplified land registry (nainly the numbering of streets) was introduced in the center of Conakry in January 1995. The establishment of the land registry for Conakry is to be completed by end-June 1996, followed by the gradual extension of land registry to the country as a whole. Finally, to strengthen the legel institutions and ensure a uniform application of the law, a Supreme Court and a High Counc1l of Magistrates were set up in late 1992. 


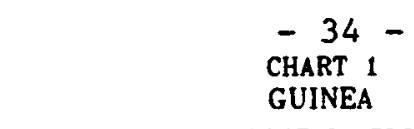

DEVELOPMENTS IN OUTPUT

(Annual percentage changes)
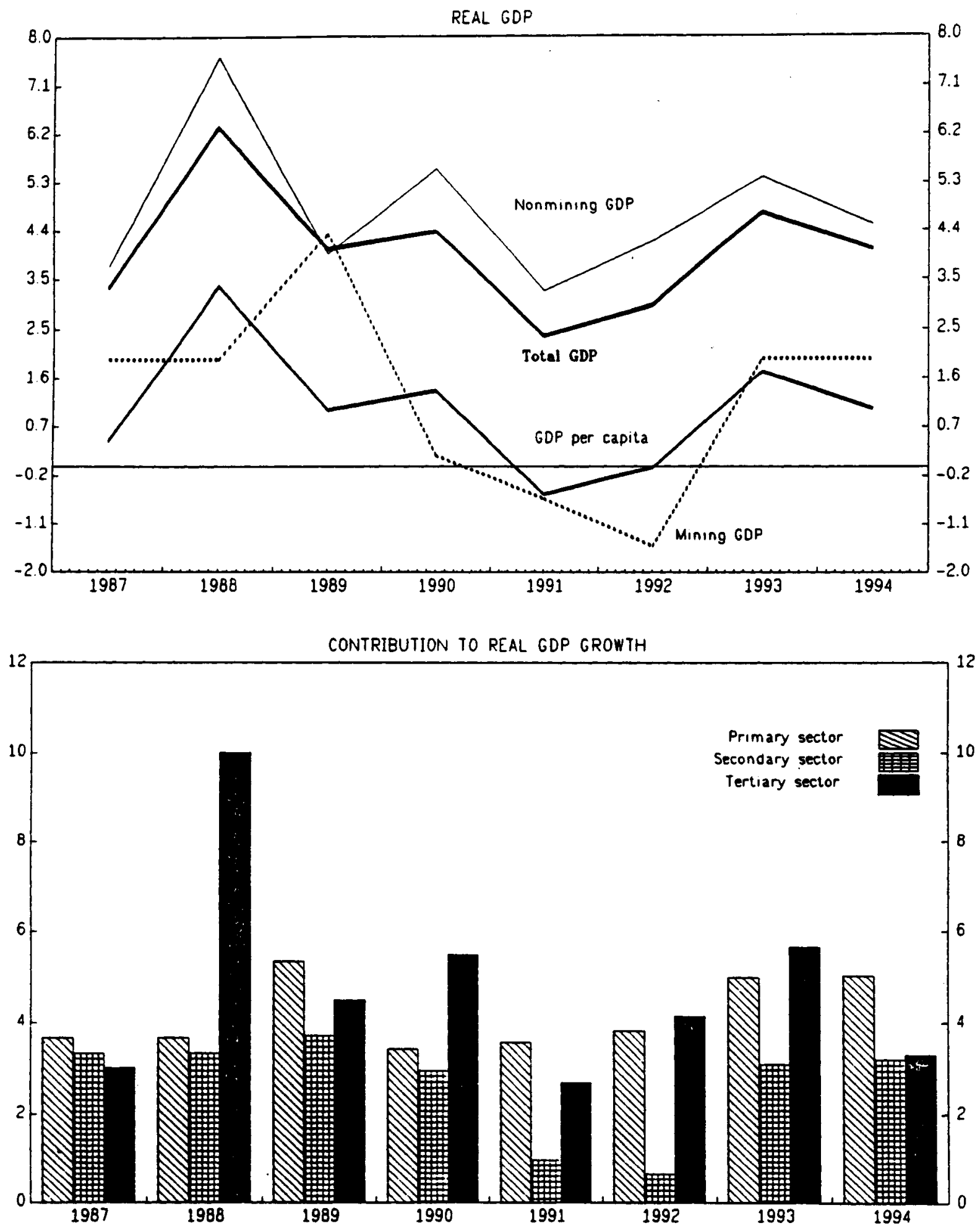

Sources: Doto provided by the Guinean outhorities; and st aff estimates. 


\section{$-35{ }^{-2}$ \\ GUINEA \\ DEVELOPMENTS IN PRICES}
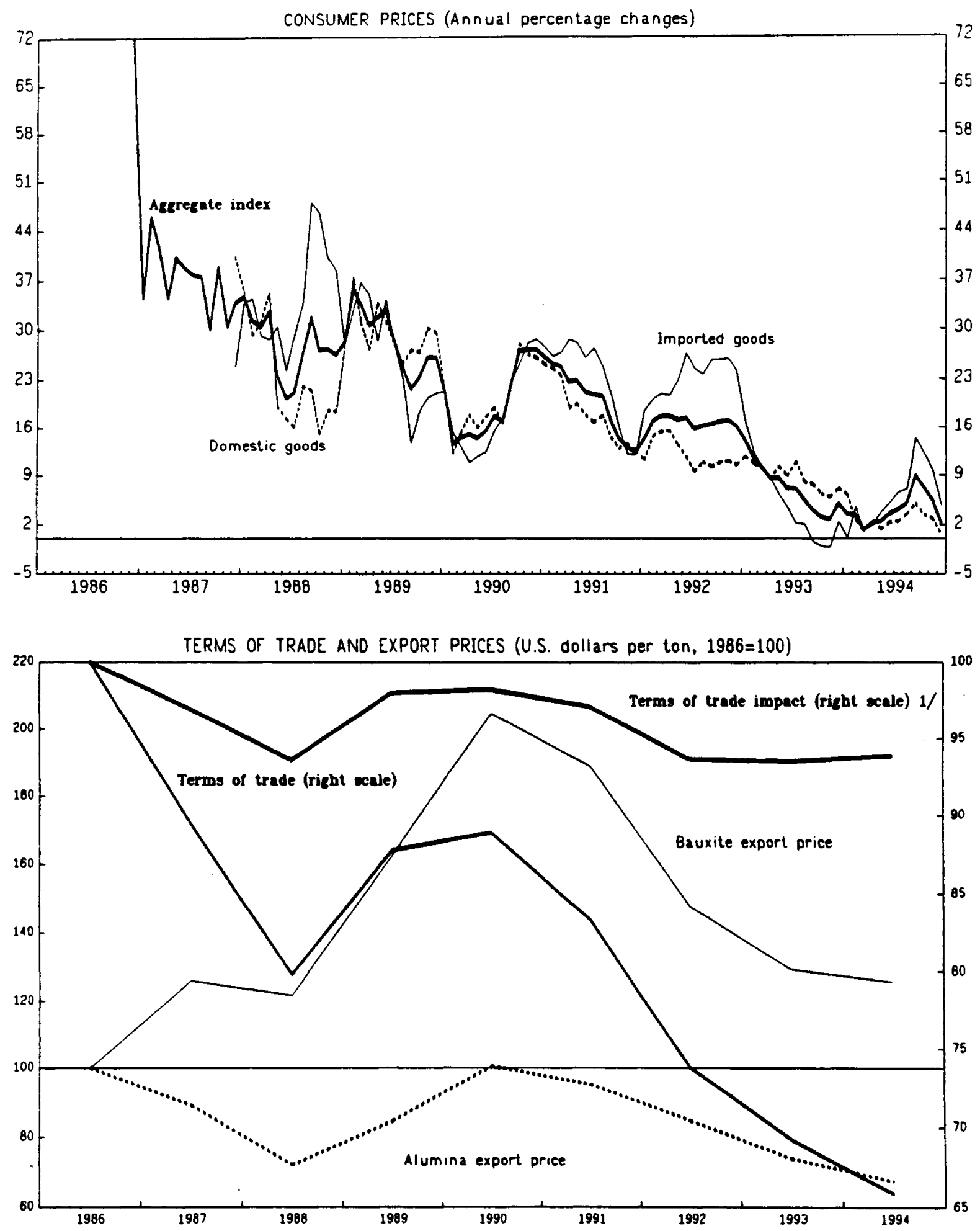

Sources: Doto provided by the Guineon authorities; and st off estimotes.

1/ Actuol real national income/Income odjusted for terms of trode chonges, in percent. 
FISCAL DEVELOPMENTS

(In percent of GDP)
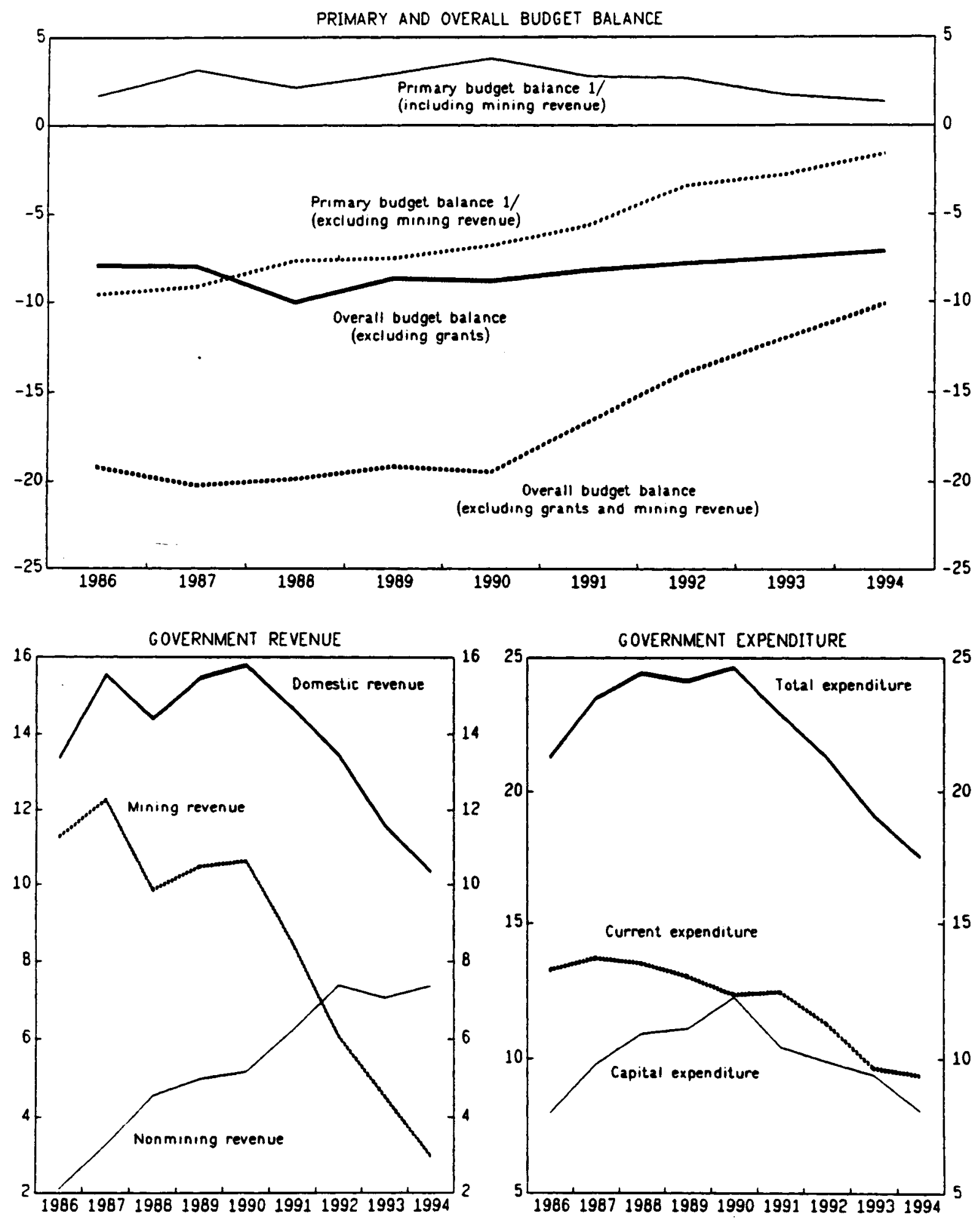

Sources: Dato provided by the Guineon outhorities; ond st aff estimotes.

1/ Revenue, minus noninterest current expenditure ond domestically financed investment. 

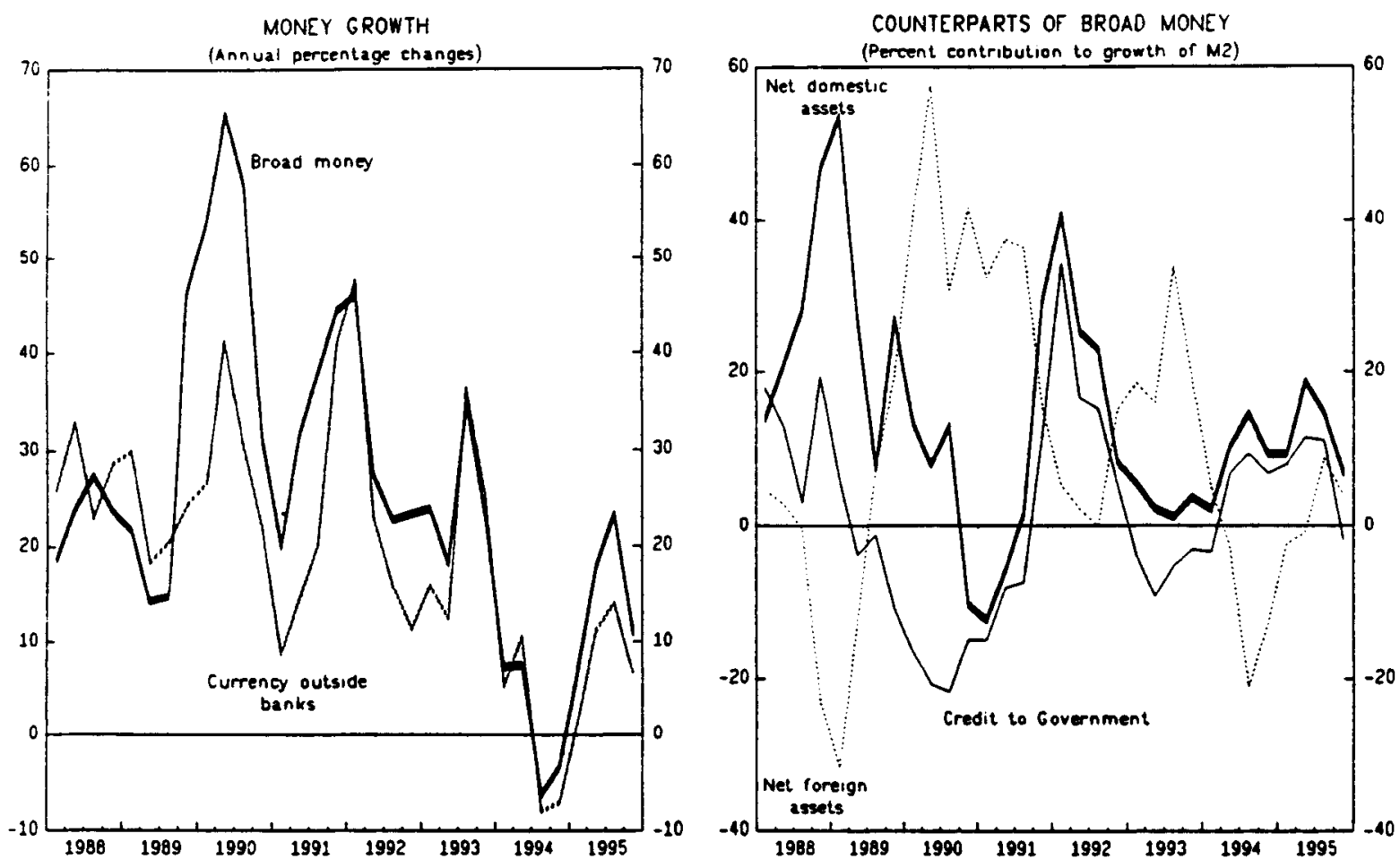

LIOUIDITY ANO CREDIT TO THE PRIVATE SECTOR

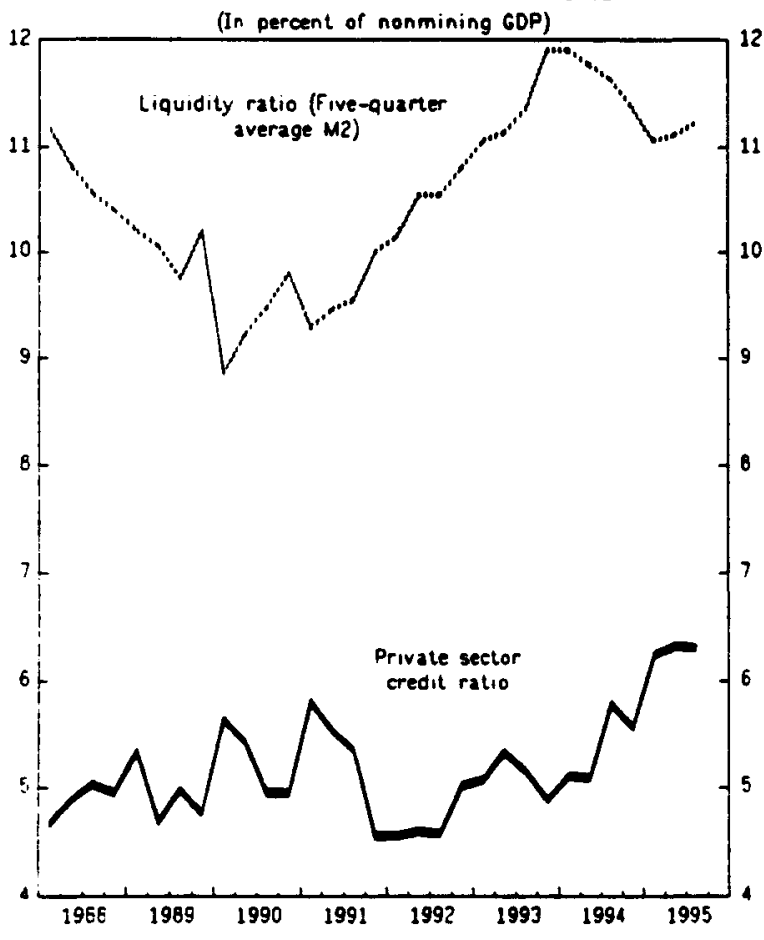

INTEREST RATES ON SAVINGS DEPOSITS

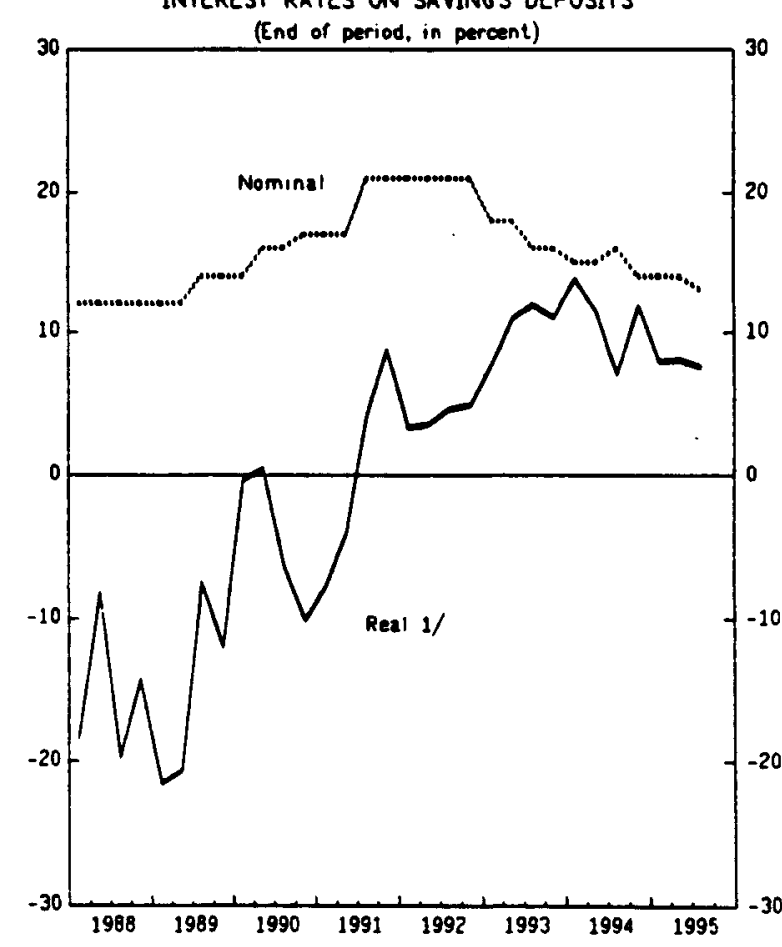

Sources: Dato provided by the Guinean outhorities: and stoff estimates and projections.

1) Nominal rate minus the 12 -month inflation rate. 


\section{KEY MONETARY VARIABLES, JUNE 1993-SEPTEMBER 1995}

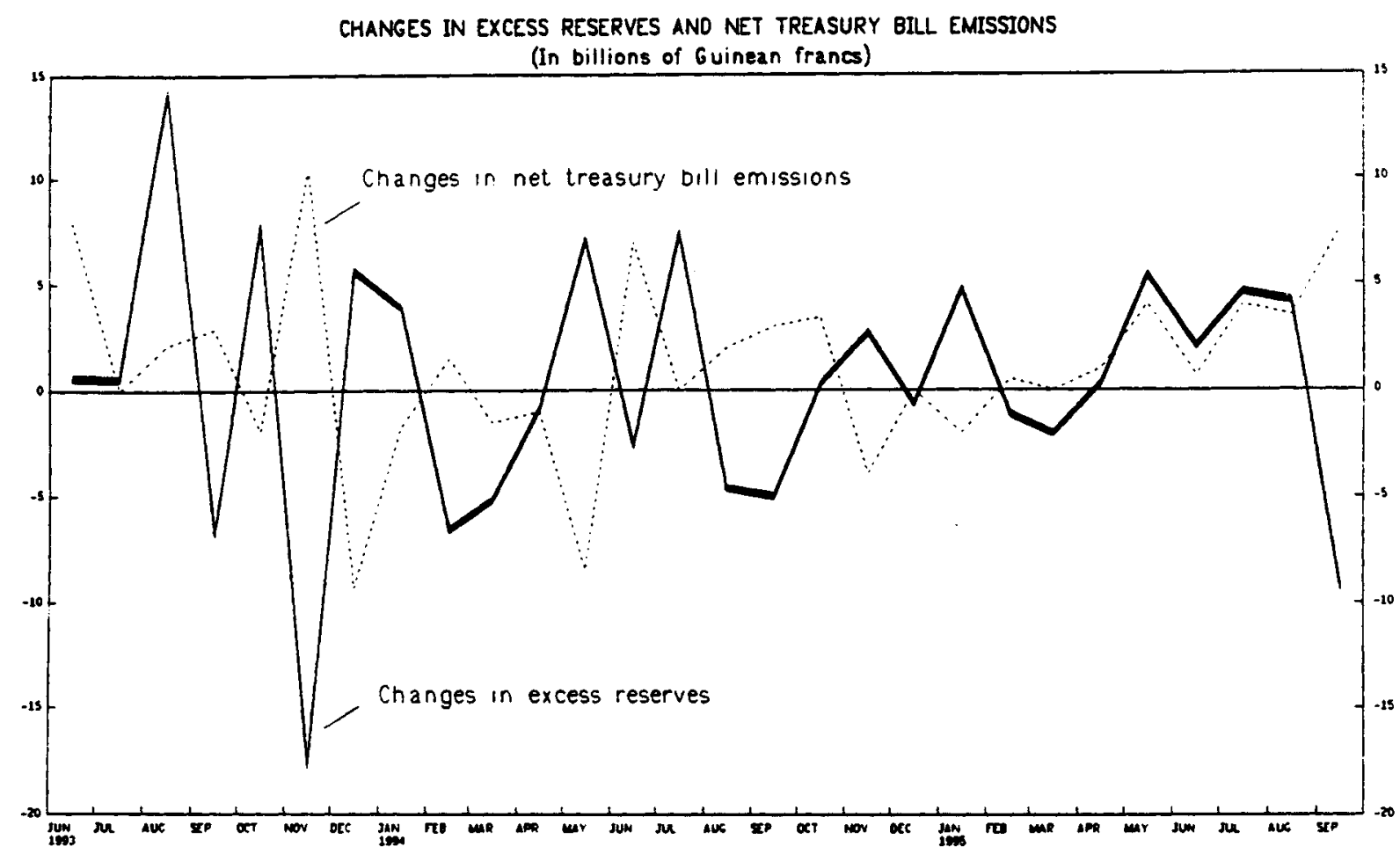

MOVEMENTS IN THE MONEY MULTIPLIER

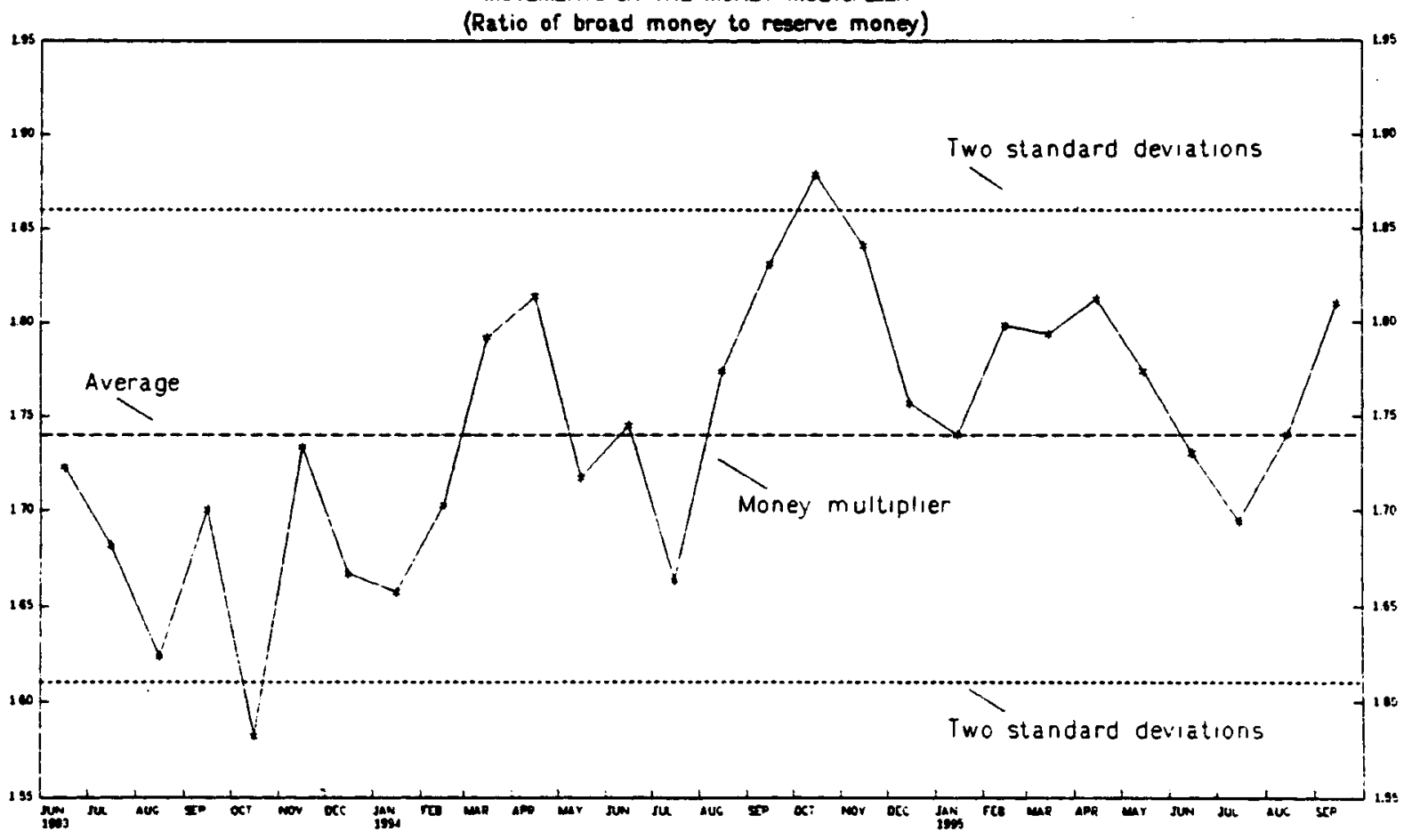

Source: Date provided by the Guineon outnorities. 


\section{EXTERNAL SECTOR DEVELOPMENTS}

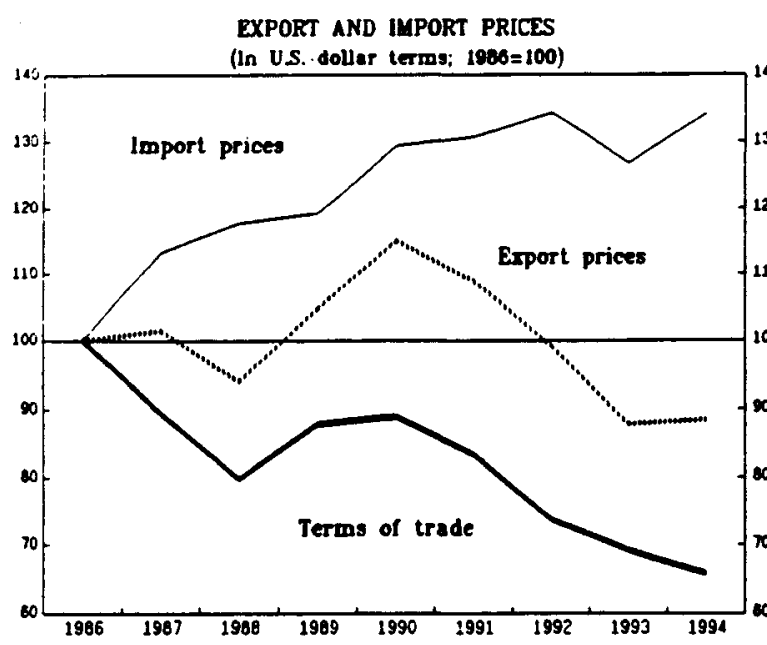

CURRENT ACCOUNT AND EXTERNAL ASSISTANCE

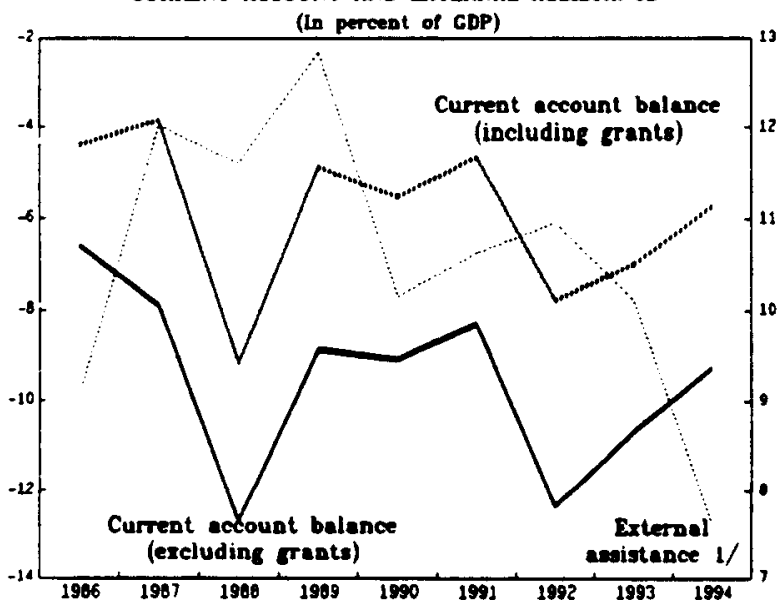

EXTERNAL PUBUC DEBT

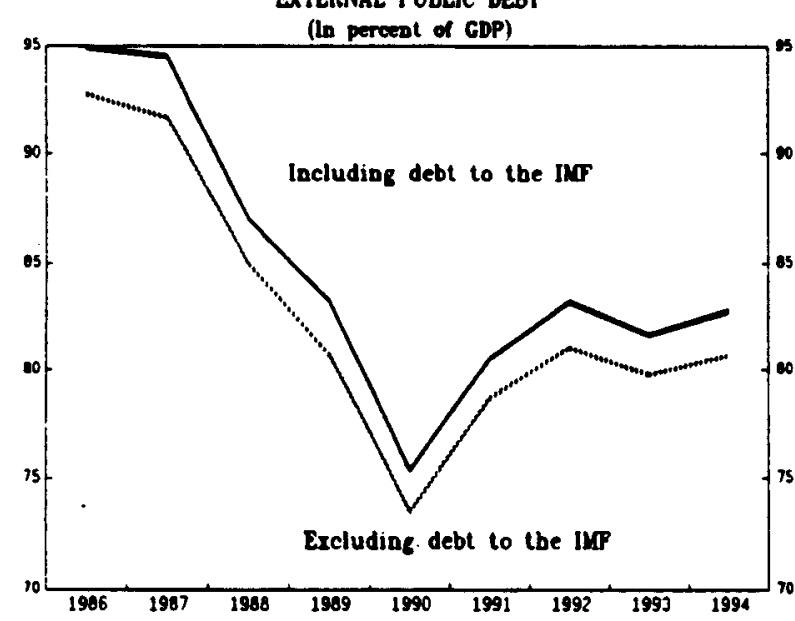

EXPORT AND IMPORT VOLUMES

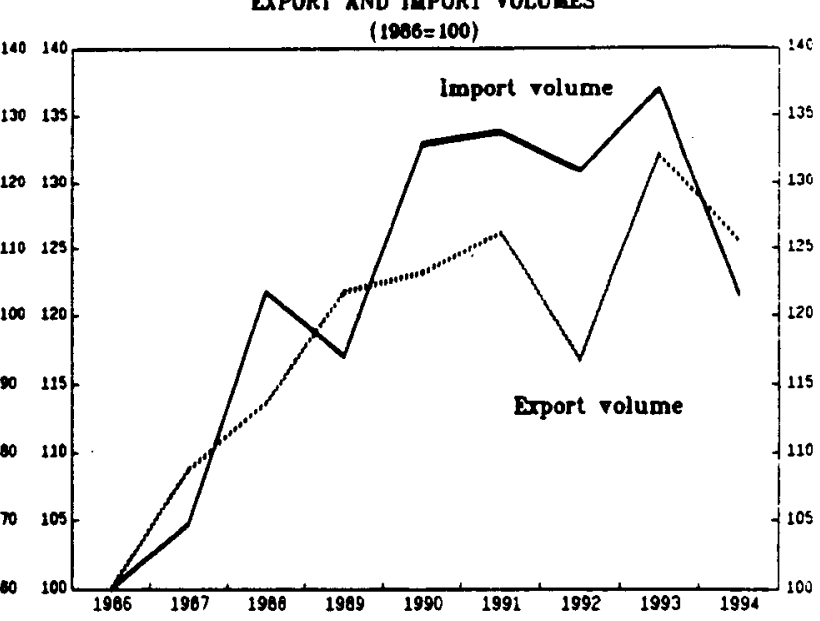

OVERALL BALANCE AND OFFICLAL RESERVES

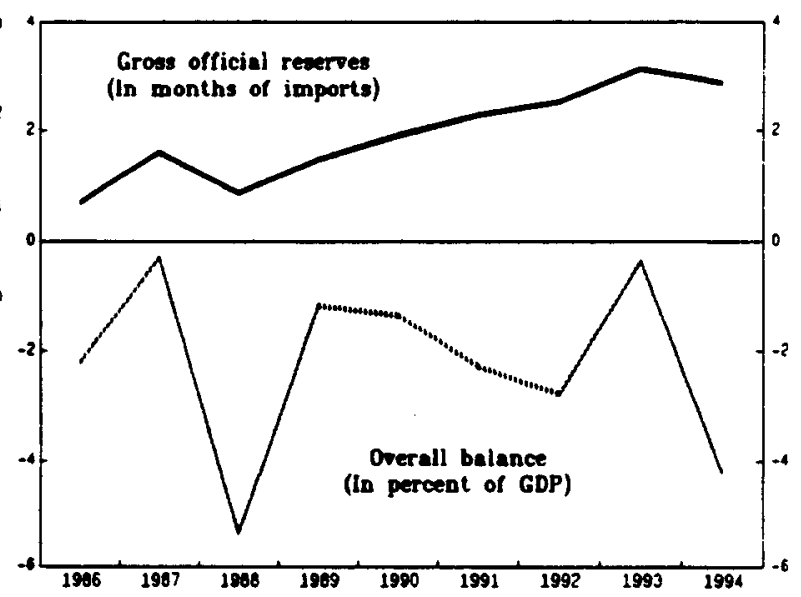

DXBT SXRVICE RATHO

(in perceel of merchandise exports)

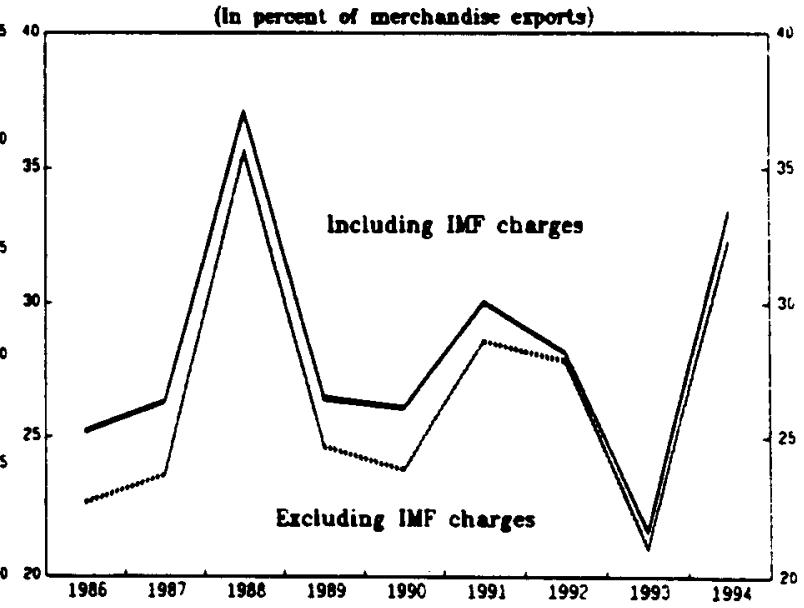

Sources: Doto provided by the Guinean authorities; and staff estimates.

1/ Inflows of official transfors and long-term concessional loons (right scalo). 
TORLD ALUMINUM PRICES AND BAUXITE AND ALUMINA PRICES

(U.S. dollars per Lon; 1986=100) 1/

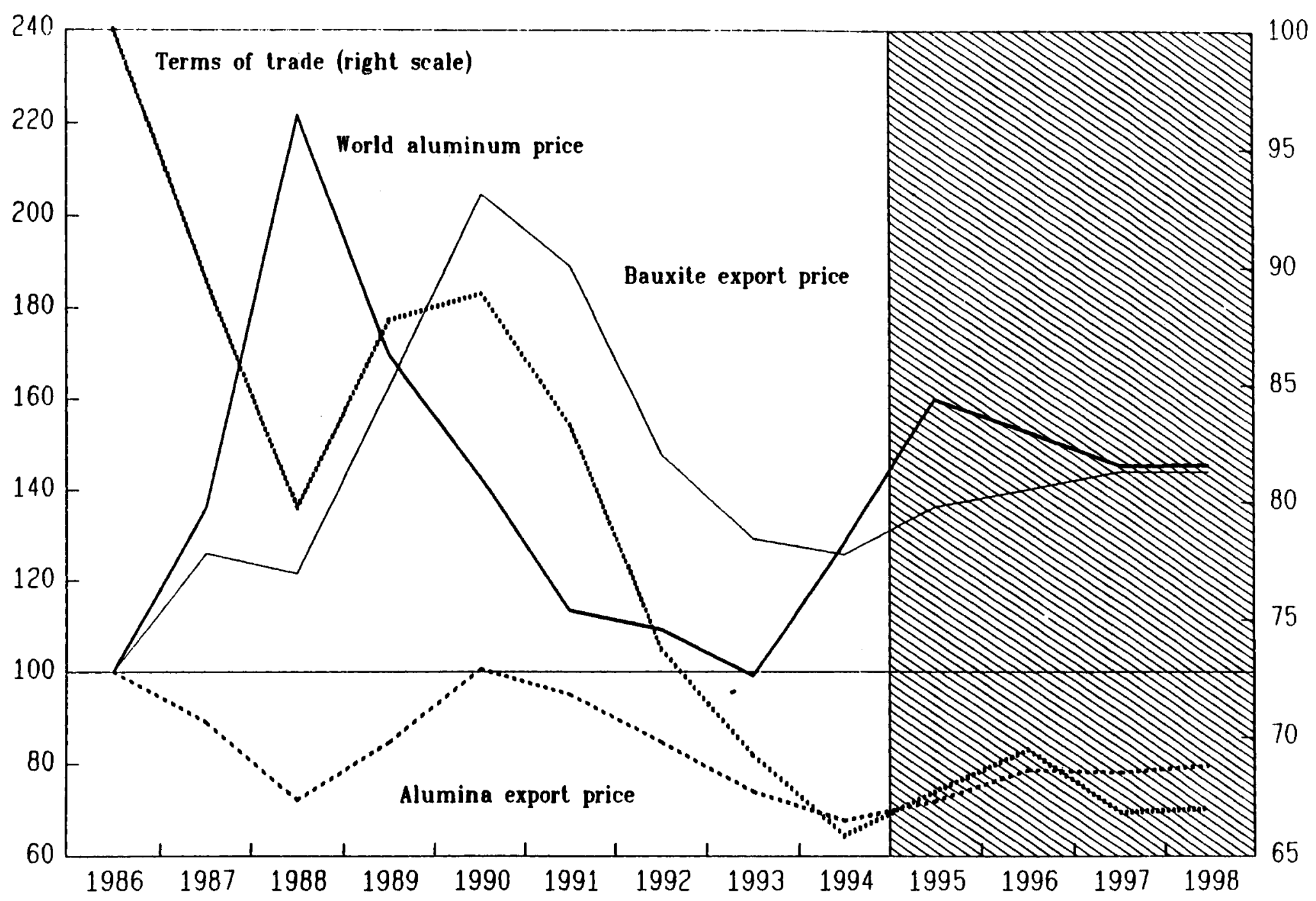

Sources: IMF, International Financiol Statistics; dato provided by the Guinean authorities; and st off estimates and projectlons.

y Projections for 1995-98. 


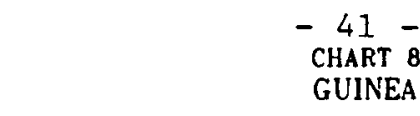

EXCHANGE RATE DEVELOPMENTS

$(1986=100)$

NOMINAL EXCHANGE RATE

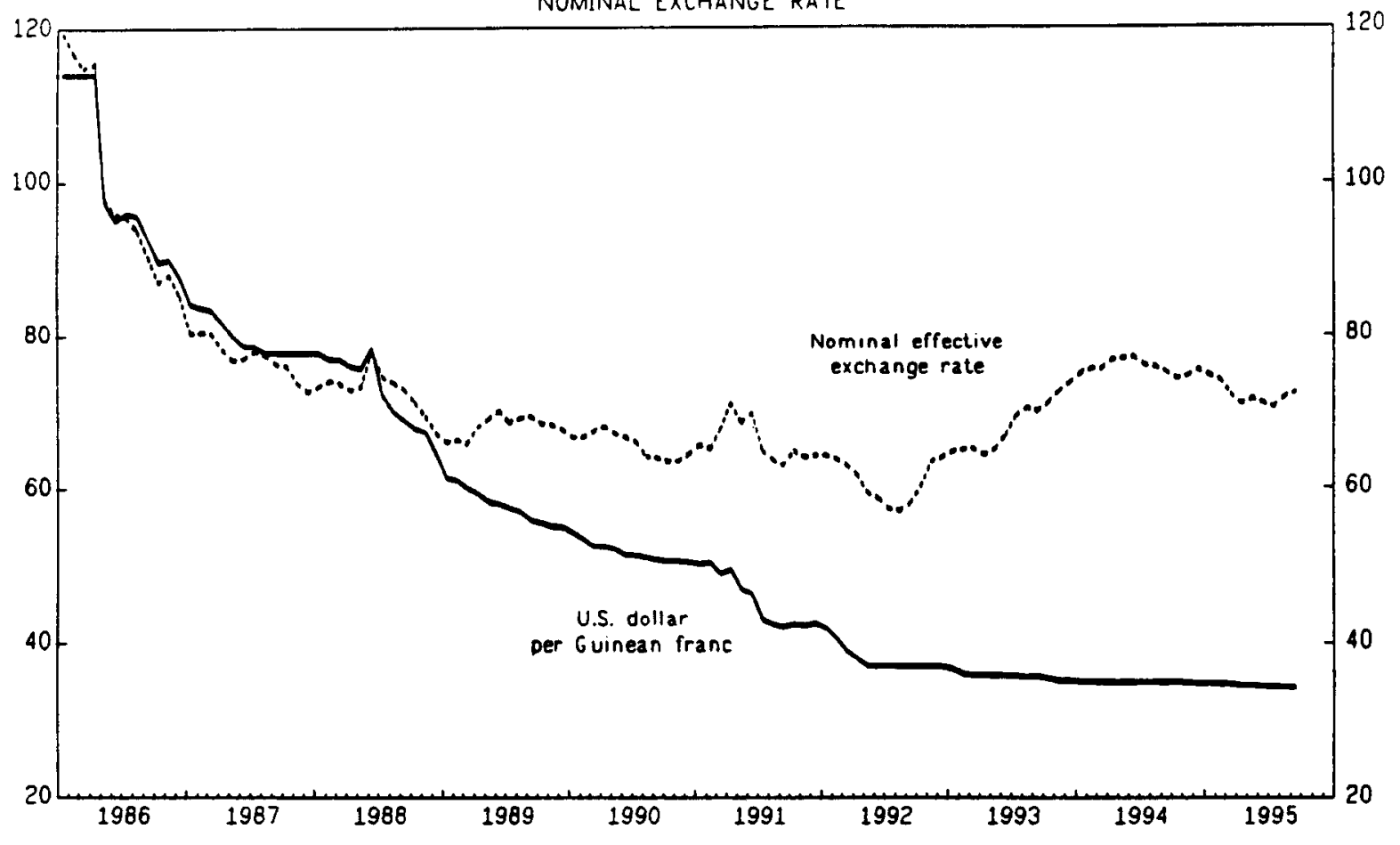

REAL EFFECTIVE EXCHANGE RATE

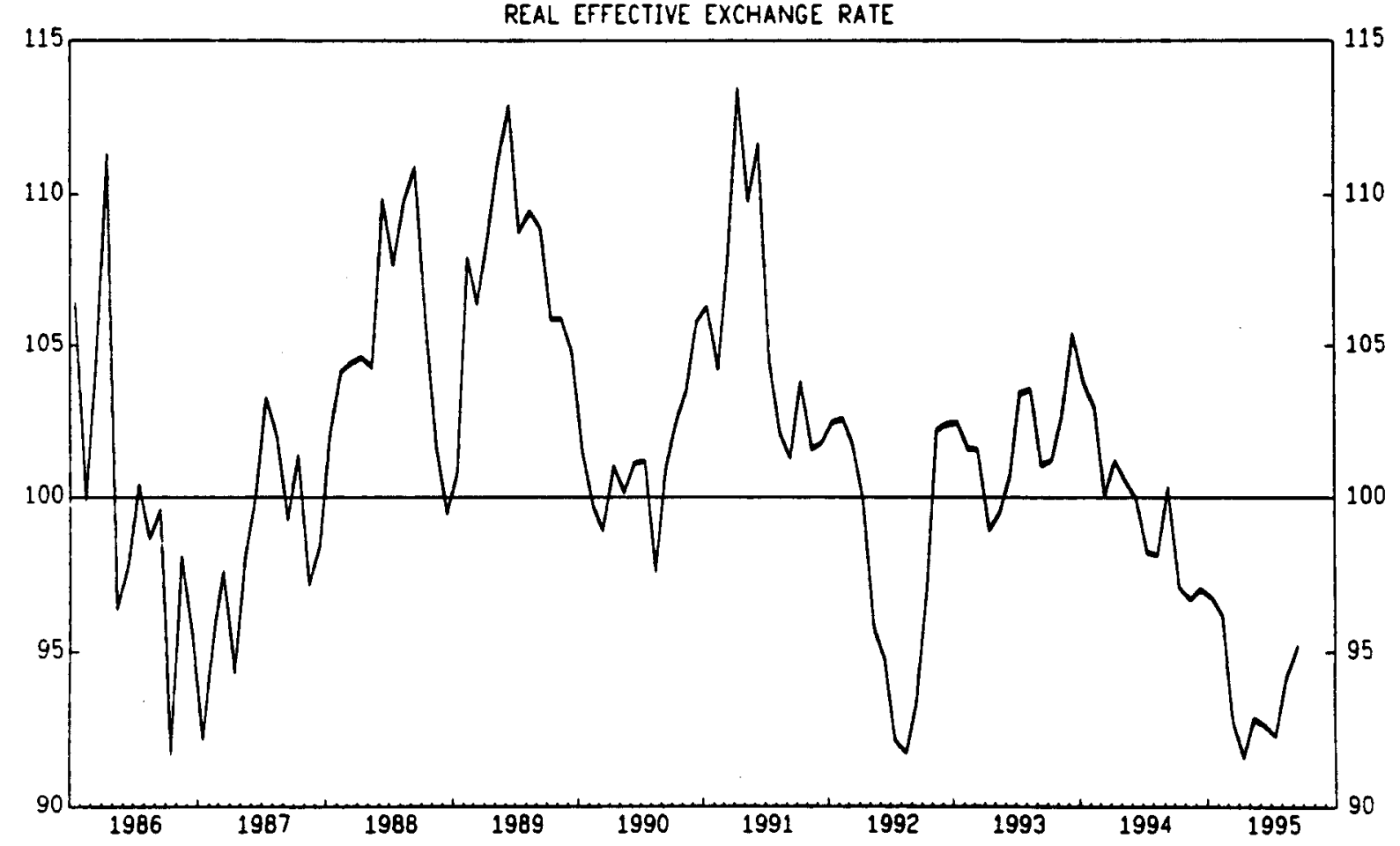

Source: IMF, Informotion Notice System. 


\section{Government Revenue Diversification and Fiscal Adjustment}

\section{Introduction}

Since independence, Guinea's budget has been highly dependent on the mining sector, which is dominated by large forelgn-operated companies engaged in bauxite and alumina mining activities. Until 1986, mining revenue accounted for over 85 percent of government budgetary revenue. While its importance has diminished somewhat in recent years, the mining sector provided over 50 percent of government revenue until 1991, reflecting mainly Guinea's narrow domestic tax base outside the mining sector, a legacy of the policies pursued under the First Republic (1958-84). In view of the decline in mining revenue, and the need to address the devastated social and economic infrastructure, the Second Republic, which took office in 1984 , increased efforts to mobilize revenue from the nonmining sector. Government revenue diversification has become the key element of Guinea's domestic adjustment in response to the decline in its terms of trade. Increased mobilization of domestic revenue was meant to contribute to the financing of government priority investments, and to the improvement of Guinea's external current account position.

Mining sector revenue has plunged in recent years, falling from a peak of 12.3 percent of GDP in 1987 to only 3.0 percent by 1994.1 In response, the Government intensified efforts to improve domestic revenue mobilization, through a set of fiscal reforms, including the broadening of the nonmining tax base, increases in petroleum taxes and import duty rates, and improvements in tax administration. As a result, nonmining domestic revenue expanded from the equivalent of 2.1 percent of GDP in 1986 to 7.4 percent in 1994 (Table 1 ), and its share in total budgetary revenue grew from 16 percent in 1986 to over 70 percent in 1994. As increases in nonmining revenue offset only part of the sizable decline in mining revenue between 1986 and 1994 , the overall fiscal deficit was reduced marginally, despite improvements in expenditure control.

A good Indication of fiscal performance is given by the evolution of the overall budget deficit, excluding mining revenue, which was reduced by 9 percentage points between 1986 and 1994. As shown in Chart A1, if nonmining revenue had remained unchanged, as a ratio to GDP, at the level of 1986, the overall budget deficit would have widened from 7.9 percent in 1986 to over 12 percent in 1994. The chart also suggests that, had mining revenue, as atio to GDP, remained at its level of 1986 , the overall budget deficit would have turned into a surplus of about 1 percent of GDP in 1994. However, despite these improvements, Guinea's nonmining government revenue performance compares unfavorably with the experience of other sub-

1 For detalls on developments in mining revenue, see Section III of the main text. For detalled information relating to this section, see Appendix II, Table 7 . 
Saharan African countries with even lower levels of per capita GDP. The efforts to raise government revenue from the nonmining sector have been seriously constrained by the persistent problems of tax evasion and fraud, notwithstanding the broad range of measures taken to strengthen tax administration.

Ieble 1. Cuines: Shares of Minins and Morminins Rovenue, 1986-94

\begin{tabular}{|c|c|c|c|c|c|c|c|c|c|}
\hline & 1986 & 1987 & 2988 & 1989 & 1990 & 2991 & 1992 & 1993 & $\frac{1994}{\text { Est. }}$ \\
\hline & & & & billtic & $10 \cos$ & $\ln f_{x}$ & men) & & \\
\hline \multirow[t]{2}{*}{$\begin{array}{l}\text { Total revenue } \\
\text { Minins } \\
\text { Nonminins }\end{array}$} & $\begin{array}{l}89.1 \\
75.1 \\
24.0\end{array}$ & $\begin{array}{r}135.9 \\
107.3 \\
28.6\end{array}$ & $\begin{array}{r}162.8 \\
112.3 \\
51.5\end{array}$ & $\begin{array}{r}222.4 \\
150.7 \\
71.7\end{array}$ & $\begin{array}{r}293.8 \\
197.6 \\
96.3\end{array}$ & $\begin{array}{l}329.9 \\
190.0 \\
140.0\end{array}$ & $\begin{array}{l}361.1 \\
162.7 \\
198.4\end{array}$ & $\begin{array}{l}351.6 \\
137.5 \\
214.1\end{array}$ & $\begin{array}{r}343.3 \\
98.5 \\
244.8\end{array}$ \\
\hline & \multicolumn{9}{|c|}{ (In peremt of totel revenue) } \\
\hline \multirow[t]{2}{*}{$\begin{array}{l}\text { Minine } \\
\text { Monminins }\end{array}$} & $\begin{array}{l}84.2 \\
15.8\end{array}$ & $\begin{array}{l}79.0 \\
21.0\end{array}$ & $\begin{array}{l}68.4 \\
31.6\end{array}$ & $\begin{array}{l}67.8 \\
32.2\end{array}$ & $\begin{array}{l}67.2 \\
32.8\end{array}$ & $\begin{array}{l}57.6 \\
42.4\end{array}$ & $\begin{array}{l}45.1 \\
54.9\end{array}$ & $\begin{array}{l}39.1 \\
60.9\end{array}$ & $\begin{array}{l}28.7 \\
71.2\end{array}$ \\
\hline & \multicolumn{9}{|c|}{ (In percent of GDP) } \\
\hline $\begin{array}{l}\text { Mintns } \\
\text { Monminins }\end{array}$ & $\begin{array}{r}11.3 \\
2.1\end{array}$ & $\begin{array}{r}12.3 \\
3.3\end{array}$ & $\begin{array}{l}9.8 \\
4.6\end{array}$ & $\begin{array}{r}10.5 \\
5.0\end{array}$ & $\begin{array}{r}10.6 \\
5.2\end{array}$ & $\begin{array}{l}8.5 \\
6.2\end{array}$ & $\begin{array}{l}6.1 \\
7.4\end{array}$ & $\begin{array}{l}4.5 \\
7.1\end{array}$ & $\begin{array}{l}3.0 \\
7.4\end{array}$ \\
\hline \multirow{2}{*}{$\begin{array}{l}\text { Budgot dofielt } 1 / \\
\text { (excludins alning } \\
\text { rovenue) }\end{array}$} & -7.9 & -8.0 & -10.0 & -8.7 & -8.8 & -8.2 & -7.8 & -7.5 & -7.2 \\
\hline & -19.2 & -20.2 & -19.9 & -19.2 & -19.5 & -16.7 & -13.9 & -12.0 & -10.1 \\
\hline
\end{tabular}

Source: Appendix $\mathbf{V}$

If On a coeniteont besis, excludins srants.

\section{b. Developments in nonminine revenue}

In view of the decline in mining revenue, and Guinea's narrow domestic tax base outside the mining sector, the efforts to mobilize revenue from the nonmining sector have relied heavily on the taxation of income and profits, the taxation of petroleum products (taxe spictale sur les produits pétroliers--TSPP), and the collection of customs duties. Improvements in taxes on income and profits resulted mainly from the identification of major taxpayers since 1989, which has led to an increase in the value of tax assessments and to better collection of arrears, as well as from gradual upward adjustments in direct and indirect tax rates. Improvements in taxes from petroleum products were the consequence of successive increases in the TSPP rates for gasoline and fuel-oll during 1991-92, as well as measures to combat fraud and tax evasion on petroleum products. The overall performance of nonmining revenue also reflects measures taken to reinforce tax administration and to reduce fraud at customs and a host of tax exemptions. Nonmining sector revenue increased fourfold between 1988 and 1992 , implying an increase of about 3 percentage points of GDP, reflecting good performance 
in the collection of taxes on income and profits, domestic production and trade, and international trade. During 1993-94, however, there was a general worsening of this performance, except in the collection of petroleum excise taxes.

\section{(1) Taxes on income and profits}

The increase in revenue from taxes on income and profits recorded during 1988-92 was due mainly to higher withholding taxes on salaries and enhanced collection rates. Their share in nonmining revenue improved considerably, from 5.8 percent in 1988 to 12.4 percent 1992 . Excluding the collection of tax arrears, personal income tax accounted for 75 percent of direct taxes in 1992, and consisted mostly of withholding on salaries in the formal sector (including the civil service), with rates ranging from 10 percent to 30 percent (Appendix I). In 1992, in particular, considerable progress was made in collecting corporate tax arrears, partly through an offset against unpaid govermment bills or current govermment payments due. Other taxes included corporate income taxes and lump-sum payroll taxes paid by employers. While the potential for corporate income tax is undoubtedly higher than what the actual collection rates would indicate, a large number of companies continue to benefit from tax exemptions under the Investment Code or under specific provisions (as in the banking sector), which were often granted for very long periods of time. The increase in revenue from corporate taxes recorded during 1994 reflects tax payment by a major commercial bank at the expiration of its concession, but also the increase in proceeds from the minimum corporate tax (impot minimum forfaitaire--IMF). 1)

Major progress was achieved in 1989 and 1990 in strengthening the direct tax administration and producing more rellable tax assessments. With the help of external technical assistance (Including assistance from the Fund's FAD), comprehensive files for major taxpayers were established in September 1990 and a large number of enterprises were audited, which resulted in a marked increase in the value of tax assessments. Although collections improved substantially, particularly during 1991-92, they continued to lag behind the increase in the value of tax assessments. The lag in tax collection not only reflected difficulties with the traditional division of responsibilities between the National Tax Directorate (DNI), which issued tax assessments, and the Treasury, which collected revenue, but it also pointed to inherent obstacles to the recovery of tax arrears. The Treasury's legal authority was reinforced in the context of the 1993 government budget, allowing the seizure of bank assets and the prosecution of delinquent taxpayers. Moreover, pending the complete transfer of the responsibility for tax collection from the Treasury to the DNI by end-1997, tax administration has been reinforced by: (1) the association of DNI's

1 In the context of the 1994 budget, the tax rate for the minimum corporate tax was raised from 1.25 percent to 3 percent, with the minimum and maximum limits raised from GF 0.5 million and GF 5.0 million to GF 2.0 and GF 20 million, respectively. 
agents with recovery activities of the Treasury through joint recovery missions since 1994 (brigades mixtes de recouvrement); and (ii) the establishment in January 1995 of a new division within the Tax Directorate responsible for the assessent and the collection of direct and indirect taxes from large enterprises (1.e., those with an annual turnover in excess of GF 150 million).

\section{(2) Taxes on domestic production and trade}

Taxes on domestic production and trade include excise taxes on petroleum products, turnover taxes on imports, and business taxes on domestic production. Revenue from these taxes increased at a rate almost twice that of GDP during 1988-94, owing mainly to improved collections in petroleum excise taxes and domestic indirect taxes, as well as the assessment processing fee (RTL) at customs.

In addition to the standard customs duties and turnover tax, petroleum products are subject to an excise tax (TSPP), set in nominal terms. $1 /$ Taxes on petroleum products increased by factor of 3.5 between 1988 and 1991 and by factor of 6.5 between 1988 and 1994. This performance reflects a system of cash payments adopted in 1990 and designed to ensure the effective collection of taxes at the time of delivery, and successive increases in the TSPP for gasoline (from GF 210 to GF 275 per 1iter in 1991 by an extra GF 150 per liter, or 55 percent, to GF 425 in February 1992), with an identical increase in the retail price (to GF 750 per liter). 2/

Measures to combat fraud and tax evasion on petroleun products (entailing the discontinuation in May 1992 of operations of a private importer supplying tax-exempt companies, principally construction companies working under PIP projects) did not materialize until the full privatization of the petroleum sector in late 1992. During 1993, collection of the TSPP continued to lag behind budget projections as a result of delays in imple. menting the new measures and the development of new channels of tax evasion, mainly with foreign ships supplying the parallel market with tax-free petroleum products within Guinea's territorlal waters. A law imposing stiff penalties on illicit sales of petroleum products was adopted in March 1994. Its strict implementation entailed the confiscation of three ships (two in March 1993 and the third in October 1993) operating in Guinea's territorial waters and the closure of network of small-scale sellers of petroleum products throughout the capital city Conakry. Consequently, petroleum tax receipts in the second quarter of 1994 were double their first-quarter level.

1 For a detalled description of the developments in Guinea's petroleum sector prior to 1993 , see SM/93/129.

2) The TSPP for fuel-oil was also increased (from GF 230 to GF 265 per liter in 1991 and to GF 415 in February 1992, while the TSPP for kerosene was kept unchanged at GF 145 per liter. Since 1994, a TSPP of GF 125 per liter has been applied to a new petroleum product (IF10, a heavy fuel-oil). 
Domestic Indirect taxes, which consist mainly of a production tax paid by local producers and the business tax levied on traders and service providers, increased from insignificant levels to about GF 9 billion in 1992 and further to GF 14 billion in 1994. This performance stemmed mainly from gradual upward adjustments of the tax rates (the tax rate on domestic production was increased in 1992 from 10 percent to 13 percent, and the tax rate on services, from 5 percent to $10-15$ percent); however, it also reflected structural reforms in the petroleum and telecommunications sectors, where the collection had previously been very weak. Collections relating to the assessment processing fee at customs (a kind of presumptive tax) also soared to GF 4.0 billion In 1992, as a result of the increase in the rate from 0.25 percent to 2.0 percent in August 1992 ; Increases in 1993-94 reflect improvements in customs administration following the computerization of customs operations (SYDONIA system).

\section{(3) Taxes on international trade}

Developments in taxes on international trade reflect customs duties which, at a standard rate of 15 percent, account for 45 percent of tax revenue collected by the customs administration in 1994. In 1994, total revenue collected by customs (excluding the TSPP) amounted to GF 112 bil. lion, or more than 45 percent of nonmining revenue. In addition to customs duties, revenue collected by customs includes the turnover tax on imports (at 13 percent), the consumption surcharge on imports of luxury items (with rates ranging from 20 percent to 60 percent), and an assessment processing fee. The major mining companies remain subject to a flat customs duty rate of 5.6 percent (except for capital good imports, which are exempted).

Since 1988, customs duties have increased steadily, on average by 34 percent per annum, to about GF 51 billion in 1994. The highest increases were recorded during 1990-91, following the increase in the standard customs duty rate from 10 percent to 15 percent in March 1990; changes made since then in the structure of customs duties and relaced taxes have been relatively minor, and affected the turnover tax on imports in mid-1992 (from 12 percent to 13 percent) and the assessment processing fee. The Government has not been able to apply these fees to imports by the mining companies, as they claim that the imposition of new taxes and fees is specifically ruled out under the existing long-term conventions with them. 1 To eliminate the existing distortions in the taxation of domestic output relative to imports, as of January 1995 the turnover tax on imports is levied on the total value of imports (inclusive of customs duty, the assessment processing fee, and other import fees).

In recent years, major efforts have been directed at strengthening customs administration and reducing tax evasion. To this end, a customs valuation office was established in 1991 and mobile squads were set up to fight smuggling. Severe penalties were introduced against customs agents

1) For a review of these conventions, see SM/93/129. 
found guilty of misconduct, and plans were drawn for the computerization of customs processing in Conakry and Kamsar, which became operational in January 1993 and April 1994, respectively. While the effective collection. rate has risen markeoly since 1989, most of the progress seems to reflect increases in the tax rates, rather than an improved performance, especially during 1990-92 (Table 2). The ratio of revenue collected by the Customs Department relative to total imports increased from 9 percent in 1989 to 17 percent in 1994. However, revenue forgone represented over 50 percent of potential revenue during 1989-93. Although there were efforts to reduce exemptions and to combat tax evasion, the implied revenue forgone due to tax exemption or evasion is still high ( 45 percent of potential revenue, or 3 percent of GDP in 1994). 1

Table 2. Guinea: Performence of the Customs Adninistration, 1989-94

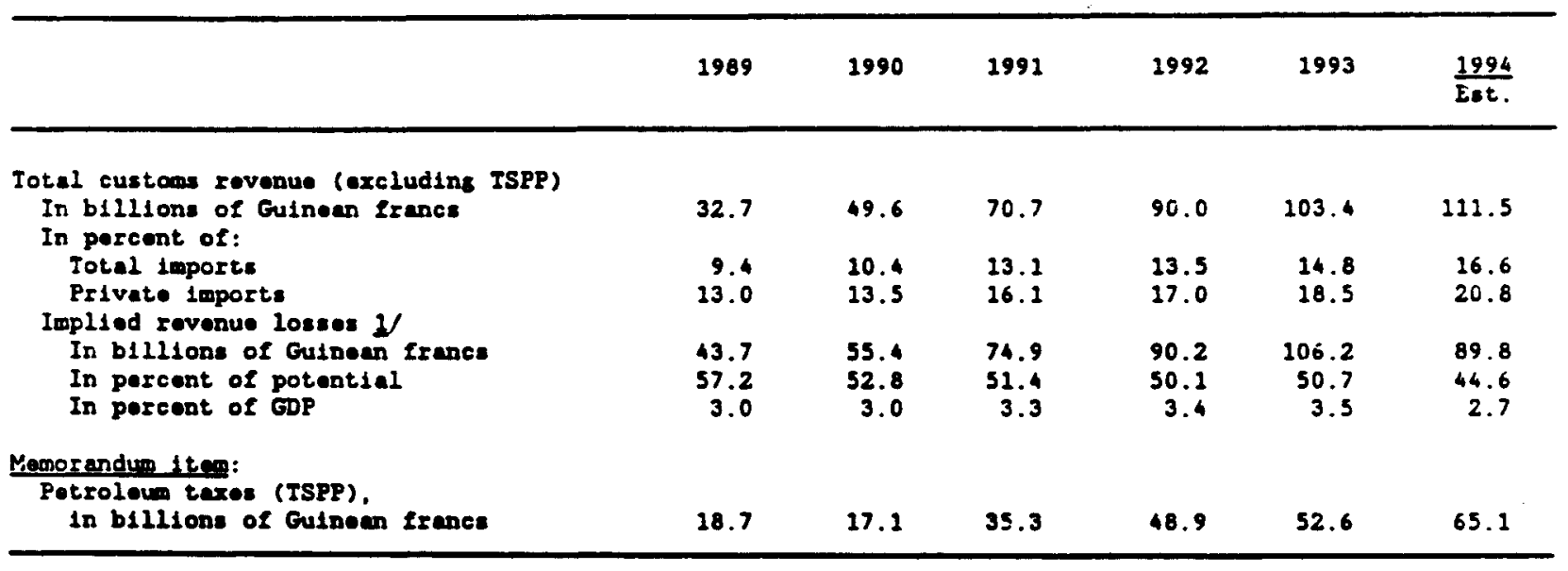

Souree: Append1x II.

Several steps were taken to overhaul exemptions as a means to fight tax evasion and fraud. A law adopted on January 28, 1990 introduced the principle of a tax-inclusive system of government expenditure (TIC system) with a view to limiting the tax evasion resulting from the granting of tax exemption contractors for public investment projects. However, for

1 For 1993-94, based on a standard overall tax rate on imports on the order of 30 percent ( 15 percent of customs duty, 13 percent turnover tax, and an assessment processing fee of 2 percent); for 1991-92, based on an orerall tax of 27 percent (15 percent of customs duty, 12 percent turnover tax, and an assessment processing fee of 0.25 percent); for 1989-90, based on an overall tax of 22 percent (10 percent of customs duty, 12 percent turnover tax, and an assessment processing fee of 0.25 percent). It should be noted, however, that in the absence of comprehensive customs statistics, this ratio constitutes a very rough estimate. Moreover, many categories of imports are naturally exempted, such as rice imports for refugees or bona fide imports exempted under the Investment Code. 
technical reasons, this provision was effectively applied to domestically financed government investments only in September 1993; the system was extended to externally financed investments in 1994.

In May 1992, the Government undertook a comprehensive inventory of all exemption arrangements. Enterprises (other than mining companies) and individuals eligible for tax exemption were given a timelimit to register with a special office set up at the Ministry of Planning and Finance, which, after screening all applications, was to issue certificates listing the exact nature and conditions of each exemption. Some 750 enterprises and individuals submitted claims for tax exemptions, of which only about 150 were deemed valid; all exemptions without a firm legal base were discontinued. Most of the tax exemption certificates were given to companies associated with public investment projects and to enterprises enjoying tax preferences granted under the Investment Code.

In late 1994, the Government conducted an independent audit of the application of the Invesiment Code, which was completed in March 1995. A number of irregular tax exemptions were identified and eliminated thereafter. The Investment Code was revised in June 1995, with a view to rationalizing the range of fiscal incentives offered to private investments in priority areas. In addition, to minimize irregularities, the 1995 budget law stipulates that only the Minister of Finance is authorized to grant tax exemptions to NGOs. All NGOs benefiting from tax exemptions were given a time-limit to register with the Ministry of Finance and about 80 tax exemptions (29 of which were foreign NGOs) were discontinued or suspended. At the same time, the Government has taken measures to ensure that import duties are paid on all imports of rice and other foodstuffs, without exception, and has strengthened the control of exempted imports by major mining companies to avold their diversion toward commercial uses. Finally, in early 1995 the Government adopted measures to combat the underinvoicing of imports (to be administered in a manner consistent with the rules of the World Trade Organization) and to ensure transparency in the assessment of import duties. $1 /$

\section{(4) Nontax revenue}

Nontax receipts include miscellaneous fees, notably administrative duties and fishing rights, and dividends from public enterprises. The increase in nontax revenue recorded since 1990 has largely been accounted for by fishing rights, which are mostly settled in the framework of an agreement with the European Union and by the strengthening of the recovery of the debt service on credits on-lent to public enterprises. Dividends from public enterprises remain small, as none of these enterprises (outside the mining sector and the banking sector since 1994) is profitable to any

1) With effect from April 1995, the value of imports and customs duties are assessed with the assistance of a private international verification agency. 
significant extent. During 1994, the collection of nontax revenue was reinforced with the transfer to the Treasury of administrative receipts collected by government departments, including rental income from public properties.

\section{c. Impediments to nonmining revenue collection}

The efforts to raise government revenue from the nonmining sector have been seriously constrained by the persistent problems of tax evasion and fraud. Tax evasion and fraud mainly takes the form of (a) illicit sales of petroleum products within and outside Guinea's territorial waters;

(b) illicit imports of petroleum products from neighboring countries;

(c) abuses of the existing system of tax exemptions on imports by contractors for government projects and by NGOs, imports of foodstuffs and petroleum products by mining companies, rice imports by the military, imports by private enterprises enjoying tax privileges under the Investment Code; (d) the low tax compliance by the formal private sector; and (e) the exclusion of most informal private sector activities from the direct and indirect tax net. Measures taken to combat tax evasion and fraud appear also to have been weakened by political considerations during the ongoing process of political liberalization.

As shown in Table 3 below, taxes on petroleum products and imports contribute the bulk (over 70 percent) of total nonmining revenue. The contribution of other domestic direct and indirect taxes remains unduly low. Given the weak tax administration, companies in the formal sector do not pay their tax obligations. Moreover, the predominantly informal nature of private sector activity outside the major mining companies, and other structural constraints, have made it very difficult for the Government to collect additional revenue. For instance, the collection of property tax obligations has been hampered by the lack of a land registry. I The table also indicates that domestic fiscal revenue (excluding revenue collected by customs) represented barely 1 percent of GDP. Finally, the level of assessments remains low, and the ratio of collections during 1994 represented only 80 percent of assessed tax obligations, reflecting inefficient tax administration.

1) A simplified land registry (mainly the numbering of streets) was introduced in the center of Conakry in January 1995. The establishment of the land registry for Conakry is to be completed by end-June 1996, followed by the gradual extension of land registry to the country as a whole. 
Iable 3. Guinoa: Domostle Texat1on of the Monminins Sector, 1989-94 If

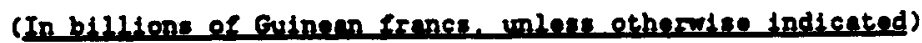

\begin{tabular}{|c|c|c|c|c|c|c|}
\hline & 1989 & 1990 & 2991 & 1992 & 2993 & $\frac{3994}{E=t .}$ \\
\hline Taxos on incene and prostte & 3.8 & 5.0 & 10.7 & 21.7 & 20.6 & 26.3 \\
\hline Taxes en compenies & 2.5 & 1.4 & 1.7 & 7.9 & 4.5 & 9.4 \\
\hline Taxes on Individual: & 1.3 & 3.6 & 9.0 & 13.7 & 16.0 & 16.8 \\
\hline Of wich: selery lacomen & $(1.2)$ & $(3.3)$ & $(7.9)$ & $(12.8)$ & $(15.0)$ & $(14.8)$ \\
\hline Payroll-releted texes & 0.5 & 0.9 & 2.3 & 5.0 & 2.3 & 2.8 \\
\hline Other dowestic tares & 4.3 & 8.2 & 8.2 & 9.6 & 20.5 & 14.7 \\
\hline of which: Indiroet texes $2 /$ & (3.1) & $(7.2)$ & $(6.0)$ & $(7.6)$ & $(9.4)$ & $(12.5)$ \\
\hline Totel doonstic flecel revenue & 8.7 & 24.0 & 21.1 & 36.2 & 33.3 & 43.7 \\
\hline In porcent of nonminins revenue & 22.1 & 14.6 & 25.1 & 18.3 & 15.6 & 17.9 \\
\hline In percent of EDP & 0.6 & 0.8 & 0.9 & 1.4 & 1.1 & 1.3 \\
\hline \multicolumn{7}{|l|}{ Menorendum ftemi: } \\
\hline Revenue collected by Custom $3 /$ & 51.4 & 66.7 & 206.0 & 138.9 & 156.0 & 176.6 \\
\hline In percent of porminins revenue & 71.7 & 69.3 & 75.7 & 70.0 & 72.9 & 72.1 \\
\hline In percent of GDP & 3.6 & 3.6 & 4.7 & 5.2 & 5.2 & 5.3 \\
\hline Asecesed domestle Elecel revenue & ... & 8.84 & 26.5 & 33.3 & 36.5 & 54.5 \\
\hline Nonmlntns revenue & 71.7 & 96.3 & 140.0 & 298.4 & 214.1 & 244.8 \\
\hline In percent of CDP & 5.0 & 5.2 & 6.2 & 7.4 & 7.1 & 7.4 \\
\hline
\end{tabular}

Source: Appendlx II.

1) Excluding revenue collectod by Cutcose.

2f Includins production tax and businees taxes.

3/ Including excise tex on potrolen products (ISPP).

\section{d. New revenue measures}

In addition to steps taken to reduce tax exemptions and to strengthen tax and customs administration as means of combatting tax evasion and fraud, the Government has inltlated far-reaching tax reforms. In the context of the 1996 government draft budget that was submitted to Parliament in October 1995 for adoption, the Government intends to overhaul the indirect tax system by broadening 1ts coverage and replacing, by April 1996 , the existing plethora of taxes with a value-added tax (VAT) at a uniform tax rate of 18 percent. The new system will allow for the deductibility of tax payments on intermediate inputs to domestic production, and would facilitate, over the medium term, a reduction in import tariffs and lower reliance on taxes on petroleum products. In addition, the Government plans to: (1) strengthen the taxation of the informal sector by applying a 3 percent tax on all imports (this tax would constitute a prepayment of direct tax liabilities); (11) overhaul the current system of excise taxes by 
adopting ad valorem taxation and by harmonizing the taxes on domestically produced and imported consumer goods; and (ii1) improve the taxation of small taxpayers by introducing a unified presumptive tax (taxe professionnelle unique, TPU) applicable to the turnover of small businesses (i.e., those with an annual turnover below GF 150 million). A large portion of TPU revenue will be allocated to local communities, which will reduce recourse to subsidies from the Central Government.

With the effective implementation of the envisaged fiscal reforms, nonmining revenue is projected to increase from 8.3 percent of GDP in 1995 to 9.8 percent in 1996. To ensure attainment of the revenue targets of the program, the Government will continue to allocate adequate means to the revenue departments, to which explicit collection objectives are being assigned on a regular basis. The design of these reforms benefitted from recommendations of several Fund technical assistance missions. In addition, to help the Guinean authorities implement these reforms, a long-term expert on tax administration from the Fund's Fiscal Affairs Department has been posted since early April 1995 as advisor to the Minister of Finance for a period of one year. 


\section{REVENUE AND FISCAL DEVELOPMENTS}

(In percent of GDP)
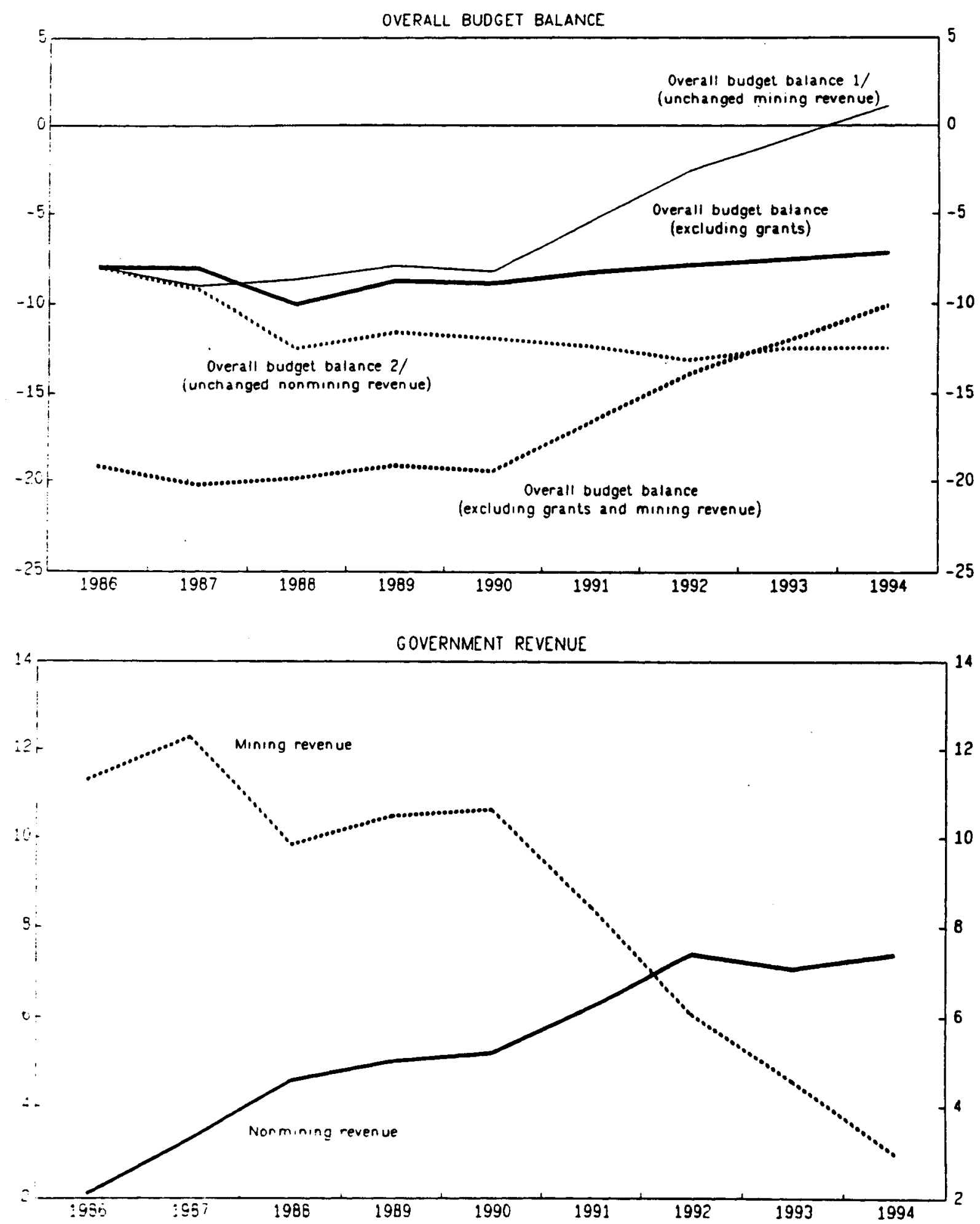

Sources. Deta provided by the Guineon outhorities; and staff estimates.

1. Some rotio of mining revenue to CDP os in 1986.

2. Some rotio of nonmining revenue to GDP os in 1986. 


\section{The Foreign Exchange Market}

\section{Exchange and trade system}

An interbank market for foreign exchange was introduced at end-October 1994, replacing the weekly auctions that had been organized by the Central Bank since 1986. The introduction of the interbank market for foreign exchange was preceded by a series of reforms in the exchange system, including (I) the eliminetion of the interest prenium of 2 percentage points carried by deposit accounts in convertible Guinean francs over deposit accounts in Guinean francs on June 3, 1993; (ii) a relaxation of the rules governing the foreign exchange bureaus, with the removal of the mandatory deposit requirement of GF 5 million and of the upper limit of US\$5,000 on their sales of foreign exchange, together with a reduction in their statistical requirements (monthly statement of purchase and sale operations, average exchange rate) on August 7, 1993; (1ii) a lowering of the fee payable to the Central Bank for the transfer of bank notes by commercial banks from 1.5 percent to 0.24 percent on August 18, 1993; (iv) a full liberalization of payments and transfers for current account transactions on July 1,1994 with the lifting of the remaining minor restrictions on foreign travel and income transfers; and $(v)$ the opening of foreign currency deposits with local commercial banks by residents.

\section{Functioning of the foreion exchange market}

The interbank market for foreign exchange began operating on November 2, 1994. I At first, because of delays in installing the required hardware, representatives from the commercial banks and the BCRG met daily to match demand and supply of foreign exchange (marche la criée). Beginning in February 1995, a computer network linking all market participants was installed in Conakry, with a view to providing a continuous flow of information to all operators. However, because of recurrent problems with the lines leased from the local telephone company, the network has functioned only sporadically so far. Efforts are under way to install new lines and improve the reliability of the system.

In practice, commercial banks post their bids for foreign exchange on the market on a daily basis, after consolidating their internal positions. Bids must be placed for the equivalent of at least US $\$ 20,000$, and are irrevocable. As a rule, bids can be unconditional (they do not specify any exchange rate - offres et demandes au mieux), or carry an exchange rate limit (offres et demandes taux limite). In addition to the Central Bank, only commercial banks are allowed to operate in the interbank market--foreign exchange bureaus can only participate through commercial

1 Rules and regulations for the interbank market were issued by the Governor of the BCRG on October 31, 1994 (Instruction No. 73/RCH/94). 
banks. 1 At end-1995, foreign exchange bureaus will be allowed to participate directly. All market transactions are subject to current exchange regulations, and require proper documentation.

\section{Recent market developments}

During the first two months of operation of the interbank market for foreign exchange, the exchange rate in the interbank market depreciated only slightly from GF 976.4 per U.S. dollar at end-October 1994 to GF 981.0 at end-December 1994. At the same time, however, the spread between the parallel market rate and the interbank market rate widened from around 3-4 percent during the third quarter of 1994 to 12 percent at year-end. Demand for foreign exchange was strong during this period, and reflected both a seasonal pickup in import demand boosted by the overall growth in the economy during 1994, and the reconstitution of commercial banks' net foreign asset position, which strengthened markedly, from US\$24 million at endOctober to US\$34 million at end-December 1994. This demand for foreign exchange could only partly be met in the interbank market through stepped-up sales by the Central Bank. 2f However, the exchange rate in the interbank market did not adjust to reflect the excess demand situation. Rather, the spread with the parallel market widened (Chart BI).

During the first half of 1995, the Central Bank sharply curtailed its sales of foreign exchange in the interbank market. 3 . At the same time, commercial bank sales of foreign exchange in the interbank market were negligible. 4/ Commercial banks, which could not obtain the desired amount of forelgn exchange from the Interbank market, had to settle import payments out of their own forelgn exchange assets. As a result, their foreign exchange position stabilized during the first quarter of 1995, and

1) This regulation was dictated by the fact that foreign exchange bureaus have operated so far on a small scale and exclusively in currency notes, whereas transactions in the interbank market are settled through transfers with correspondent banks abroad.

2) The Central Bank's sales of foreign exchange to the commercial banks rose from some US\$15 million on average in September-October 1994 to US\$18 million in November and US\$28 million in December (compared with US\$15 million and US\$18 million in November and December, respectively). Nevertheless, the official reserve position remained broadly stable during the period.

3 Sales dropped to about US\$9 million in January and February 1995, and US\$7-8 million on average during March-June. At the same time, the BCRG purchased more than 4 tons of gold, which increased pressures on the foreign exchange market.

4/ They reached US\$1.8 million only (US\$400,000 in both January and February 1995, and US\$1 million in April, while they were nil in March, May, and June). 
then dropped sharply to a record low of US\$15 nillion at end-June 1995 . The contraction of the commercial banks' net foreign exchange assets also reflected the Central Bank's lowering of limits on their external positions, effective December 6,1994 , as well as a more rigorous implementation of the mandatory reserve requirements from early 1995 onward. I/ However, there again, the exchange rate in the interbank market remained broadly stable relative to the U.S. dollar, depreclating by a cumulative 1 percent, while the spread with the parallel market narrowed to around 5 percent in April 1995, then widened again, to more than 10 percent at end-June. $2 /$

The imperfect functioning of the interbank market for foreign exchange is evidenced by the stability of the interbank exchange rate compared with the variability of the spread with the parallel market rate, as market pressures have been shifted to the parallel market. The market for foreign exchange in Guines is largely segmented.

On the supply side, the Central Bank is a net supplier in this market. 3 / The weight of the Central Bank is overwhelming; even during the first half of 1995, when the BCRG reduced its sales in the interbank market, it still supplied close to 30 percent of aggregate supply. The forelgn exchange resources of the Central Bank originate almost entirely from tax payments from the mining companies, which operate in Guinea as offshore enclaves, and from external aid disbursenents. Under current rules and regulations, exporters of bauxite and nonartisanal diamonds are generally required to pay their tax obligations in foreign currency through the Central Bank.

On the demand side, the bulk of foreign exchange outflows in the interbank market corresponds to the settlement of irrevocable letters of credit, upon the delivery of imports. In such cases, decisions were made several months earlier, and cannot be altered by the time payments become due. As a rule, the settlement of letters of credit also bears the commercial banks' guarantee that transfer of forelgn exchange will be effected out of their own resources, If needed. The room for maneuver for commercial banks is thus limited to spot transactions on nonfactor services, including travel allowances and transfers, which typically account for no more than 5-6 percent of payments in forelgn currency channeled through

1 An Instruction of the BCRG (No. $75 / \mathrm{RCH} / 94$ ) lowered the banks' maximum net foreign assets to 40 percent of their paid-in capital, down from 60 percent in February 1994.

2) Reflecting the weakening of the U.S. dollar vis-a-vis other major currencles, the Guinean franc depreciated by about 5 percent in nominal effective terms during January-May 1995.

3) Forelgn exchange transactions totaled US\$174 million during the first half of 1995, of which 71.5 percent were met internally, 27.5 percent from BCRG sales, and 1.0 percent from commercial banks in the market. 
conmercial benks. These transactions are the most likely to shift to the parallel market when restrictions are felt in the interbank market. 1

The supply of foreign exchange in the parallel market consists of the receipts from smuggling of diamonds and gold, tourlsm and other exports of services, and private transfers. On the demand side, operations involve smuggling and illegal activities on international current transactions, and capital outflows. The transaction cost is minimal, and the market is not submitied to foreign exchange regulations. As a result, the demand in the parallel market cannot be shifted to the interbank market. At the same time, the paraliel market is not willing to supply the interbank market at a lower rate.

In response to pressure on the interbank market, the unmet demand for foreign exchange is iikely to shift to the parallel market, rather than attract grester supply in the interbank market, because transactions in the parailel market present the advantage of not requiring any form of documertation. Transactions in the parallel market take place both in cash and In the form of direct transfers of balances held abroad, mainly in the form of U.S. dollars. The spread with the interbank market reflects in part the premiul that traders are willing to pay for buying forelgn exchange without any supporting documents, either for import financing (thus facilitating import underinvoicing and tax evasion) or for capital outflows.

The introduction of the interbank market was designed to improve the allocation of foreign exchange by establishing a market-determined exchange rate and widening the sources of foreign exchange. Developments since late 1994, when the interbank was introduced, suggest that only 1imited progress has been made toward this goal. As the BCRG sought to strengthen its foreign assets position, it has restricted the supply of foreign exchange in the interbank market. In turn, the commercial banks have at times rationed their customers, some of whom have presumably switched to the parallel market. No data are available on unmet demand in the interbank market, but representatives from the commercial banks as well as from the BCRG confirmed that bids sometimes remained unfulfilled.

The full-fledged development of the interbank market would require that steady sources of forelgn exchange be channeled through commercial banks, so that they become net suppliers on a regular basis. As before, however, the Central bank could continue requiring proper documentation and regulating the net foreign asset position of commercial banks. In addition, greater flexibllity should be allowed on the demand side by allowing importers to cover part of their imports by purchasing some of their foreign exchange needs at the time import letters of credit are opened. This would ensure that part of the demand for forelgn exchange becomes sensitive to changes in

If Once in eerly 1995, a commercial bank offered foreign exchange in the market at a premium over the ongoing exchange rate, but no buyer could be found. 
the market conditions. Indeed, over the nedium term, and with the strengthening of the domestic banking system, most export proceeds would flow through commercial banks and help deepen the market for foreign exchange. 


\section{EXCHANGE RATE DEVELOPMENTS, 1994-September 95}

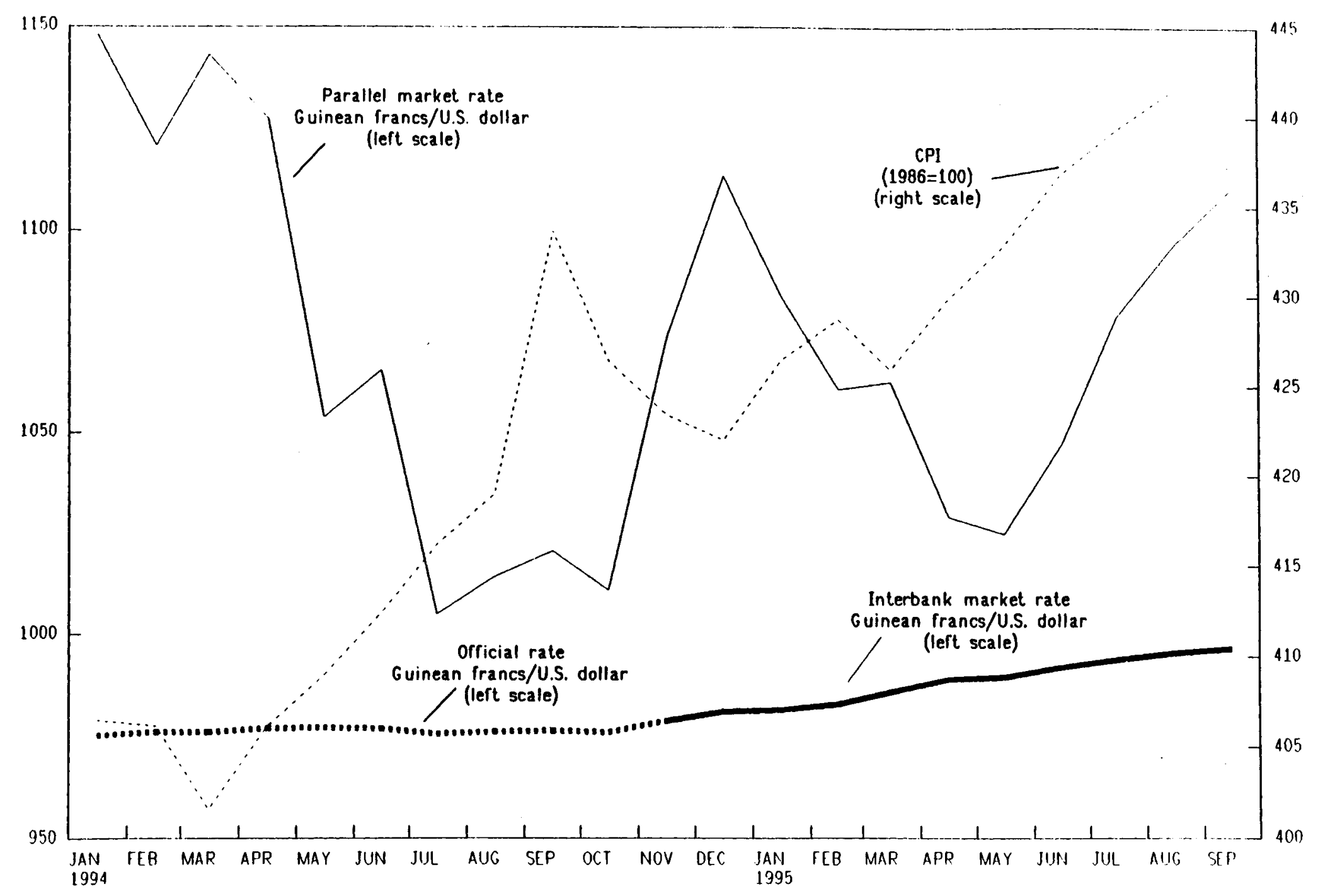

Source: IMF, Information Notice System. 


\section{External Debt Sustainability Analysis}

Guinea is a heavily indebted poor country. At end-1994, Guinea's outstanding mediun-and long-term public debt amounted to US\$2.8 billion, equivalent to 82.8 percent of GDP. I/ of this amount, 48 percent was owed to international organizations, 29 percent to Paris Club creditors, 21 percent to other bilateral creditors (including 8 percent to Russia), and the rest to commercial banks and suppliers. The IDA ranked the highest among Guinea's multilateral creditors with a 58 percent share, followed by the AfDB/AfDF group (19 percent of total debt, of which 15 percent was owed to the AfDF); 2 (he Fund accounted for 5 percent, the remainder was distributed among other reglonal development banks, investment banks, and development funds. Of the total outstanding debt, arrears amounted to US\$189 million, of which US\$132 million was rescheduled by the Paris Club creditors in January 1995, and the remaining arrears are expected to be eliminated in 1995, either through rescheduling or cash payment. 3 / Following the debt reductions and reschedulings granted to the country over the past ten years, and taking into account the large share owed to multilateral institutions, most of Gulnea's debt is presently ineligible for new rescheduling; at end-1994, the stock of reschedulable debt (pre-cutoffdate debt to bilateral creditors not previously rescheduled or rescheduled on nonconcessional terms in 1986, and commercial debt) amounted to US\$313 million ( 11 percent of total external debt outstanding). 4/

In order to assess the sustainability of Guinea's debt service capacity, the medium-term balance of payments projections have been extended to cover a 20-year period. These projections are predicated on Guinea continuing the adjustment path so as to foster the sustainable development of its economy. The principal assumptions of the baseline scenario are:

- An average real GDP yearly growth rate of 5 percent. Attainment of this objective would require the doubling of gross national savings (excluding official transfers) to about 12 percent of GDP by 2014 and an expansion in gross investment of over 2 percentage points, to about 16 percent of GDP.

1 The net present value (NPV) of Guinea's public debt stock at end-1994 is estimated at US\$1.4 billion (implying a grant element of 50 percent).

2) AfDB/AfDF, African Development Bank/Fund.

3/ US\$11 million was due to other bilateral creditors, and US\$32.4 million was related to the postal debt; the rest was due to private creditors.

4/ This excludes debt to Russia (US\$231 million) that is assumed to be rescheduled on terms at least comparable to those of the 1992 Paris Club rescheduling. 
- An average real export growth of 10 percent during 1995-2002, and 7 percent during 2003-2014. I Real imports are projected to grow by. 7 percent on average (assuming an income elasticity of 1.3).

- New financing would grow by 7 percent a year in nominal U.S. dollar terms over the entire period, with project-related inflows constituting the bulk of external financing. Grants would account for about 40 percent of total external assistance. Loans--mostly from multilateral institutions--would be contracted on highly concessional terms, at an average interest rate of 2 percent a year, a maturity of 26 years, with a 6 -year grace period, entalling a 60 percent grant element.

- A Paris Club stock-of-debt operation on Naples terms (50 percent net present value debt reduction) is assumed to be implemented in the last quarter of 1996.

On this basis, the external current account deficit (excluding official transfers) would decline by 5 percentage points, to 3.5 percent of GDP by year 2014. The debt burden would be reduced gradually over the next 20 years. The debt service ratio after debt restructuring would decline continuously, from 21 percent of exports of goods in 1995 to 14 percent by 2014. The debt/GDP ratio would fall steadily from 79 percent in 1995 to 52 percent in 2004, and to 38 percent by 2014. The share of multilateral debt service in total debt service is projected to increase significantly, from about one third currently to two third by 2014, given the long maturities of these loans. The net present value of the external debt as a ratio to exports of goods and services is expected to decline significantly over time, falling to about 170 percent by 2000, and to 130 percent by 2004 , about a half of its current level.

The burden of external public debt service on public finances would also become lighter over time. As the structural adjustment program adopted by the authorities aims at increasing government revenue (from 11.5 percent of GDP in 1995 to 21 percent of GDP by year 2014), the ratio of external debt service to budgetary revenue (excluding grants) is projected to decline considerably from 36 percent in 1995 to 20 percent in 1997-2000, and to 13 percent by 2014 .

While this analysis shows that Guinea's debt burden appears manageable over the next 20 years, it is subject to a considerable degree of uncertainty. The balance of payments outlook is sensitive to a number of risks, including weaker bauxite and alumina export prices, the stance of financial policies, the supply response of the nonmining export sector, and the terms of new external financing. The sensitivity analysis set forth in Table 2 and in Chart $\mathrm{Cl}$ shows the impact of lower bauxite and alumina export prices,

1) These relatively high growth projections are based on Guinea's vast potential, and reflect the expected impact of adjustment policies on the development of the country's agriculture and nonmining sectors. 
lower nonmining exports, and less favorable financing terms on the debt service burden. Specifically, if export prices of bauxite and alumina were 10 percent lower during the projection period, the debt service ratio would be higher by almost 1 percentage point of exports earnings during 1995-2005, and by $1 / 2$ of 1 percent during 2005-14. Similarly, if nonmining company exports were 10 percent lower, the debt service ratio would worsen by about 1 percentage point of exports. Finally, if new borrowing were to be contracted on less concessional terms ( 40 percent grant element relative to a 60 percent grant element in the baseline scenario), the debt service ratios would be 2 percentage points higher during 1995-2004, and almost 5 percentage points higher during 2005-14. The deterioration in external conditions would widen the current account deficit (in the order of 1 percentage point of GDP) and result in substantial financing gaps; this would call for a major compression of absorption, and/or additional external assistance. 
Table 1. Guinea: Key Indicators of Exrernal Indeble dness. 1995-2014 (in millions of US. dollars, unless otherwise indiceted)

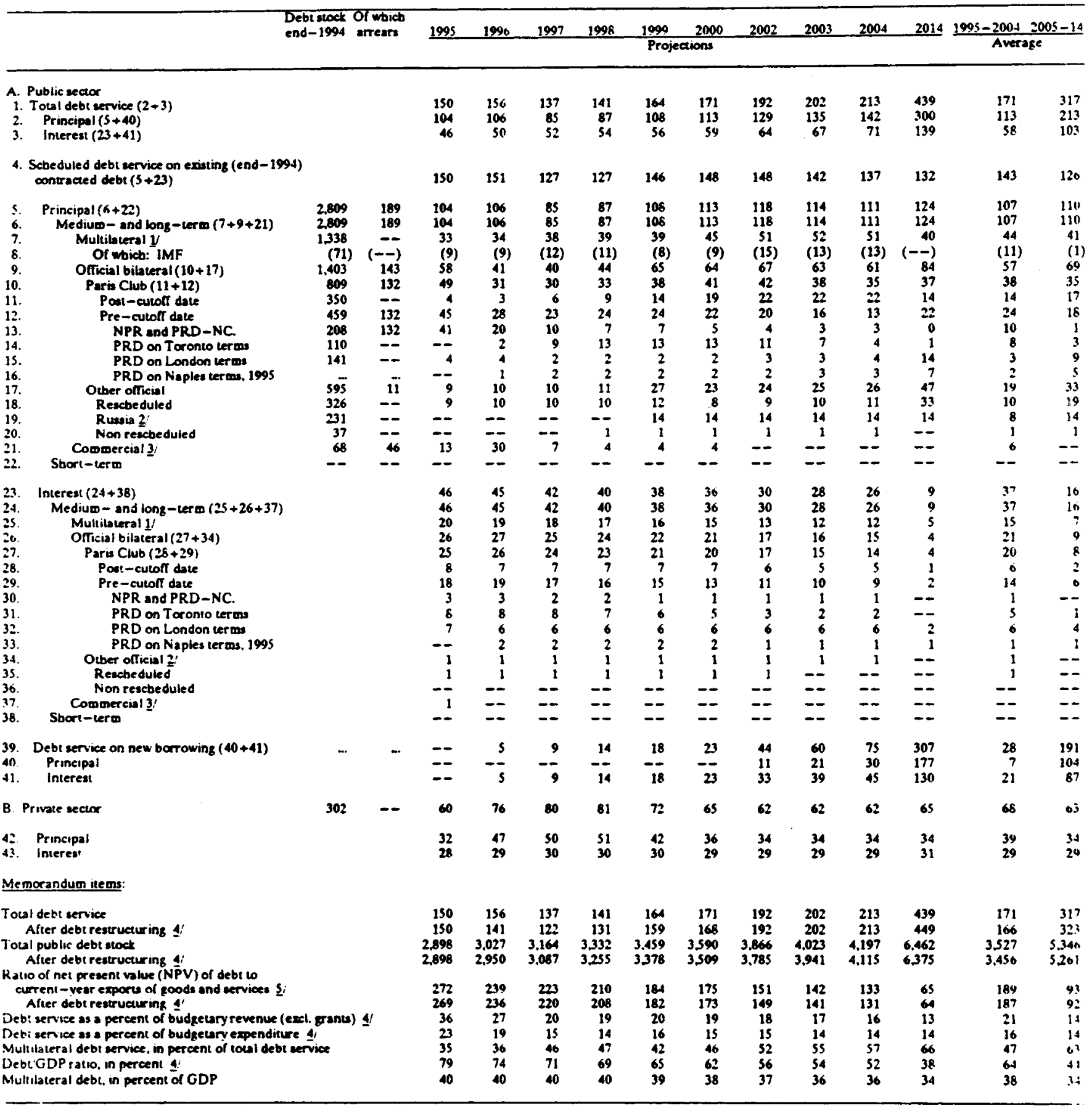

Sources: Minisury of Finance; and staff eatiwates and projections.

1 Including aganizations of Arab countries.

2 It is assumed that debt $w$ the FSU was in artears at end-1992, and tbus reschedulable on terms at least comparable wo bone of the Paris Club resche duling of November 10y2. The value in US. dollars is based on an accounting exchange rate of rub 0.557 per US. dollar.

3 Including the telecommunications debt (USS32.4 million).

4 Assuming a 30 percent NPV stock operation during the last quarter of 199; this operation is applicable wo an estimated end-September 1996 pre-cutof - date debt of IISS IS? milhon to Parta Club aredicars (NPR and PRD-NC). and coomercial credicars (NPR).

: Aesuming an average discount of 8.6 percent. 
Table 2. Guines: Analysis of the Sensitivity of the Balance of Payments to Bauxite and Alu mina Prices, Nonmining Exports, and Terms on New Borrowing, 1994-2014

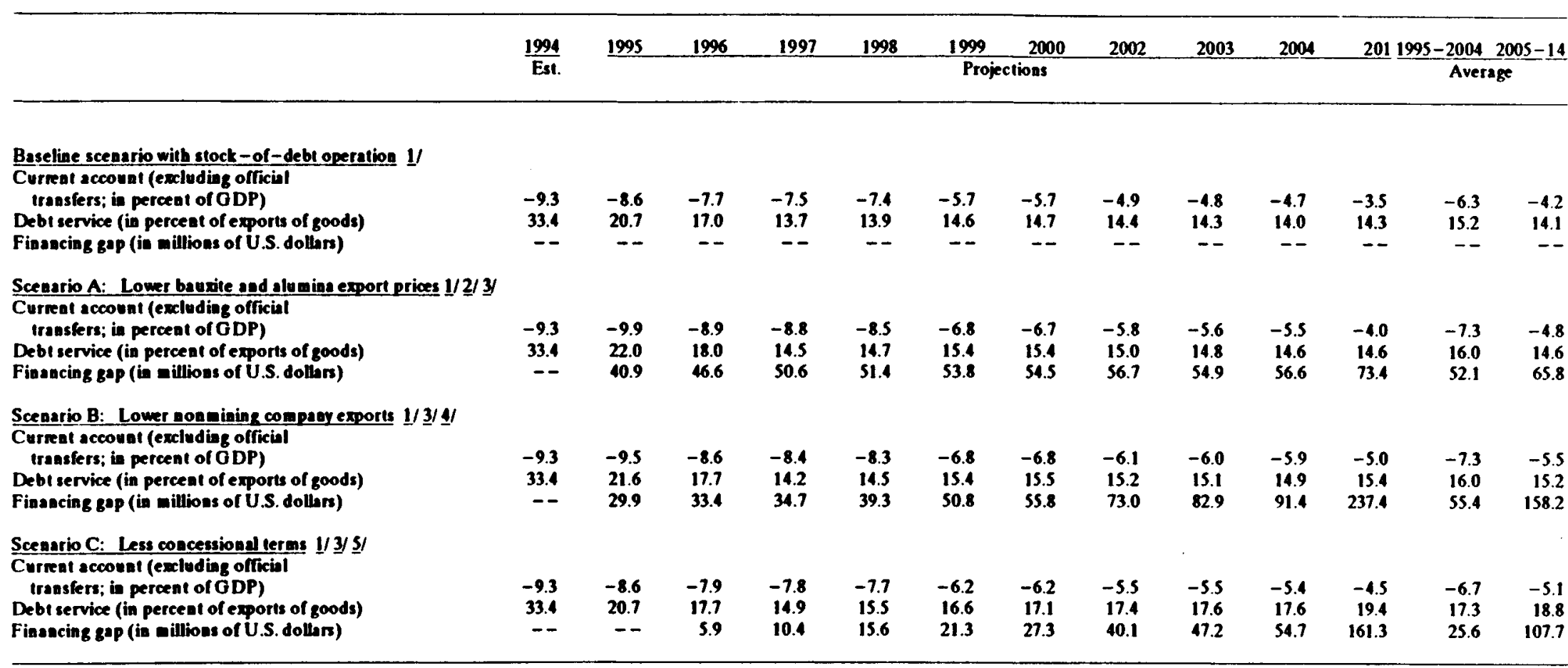

Source: Staff estinates and projections.

1/ Assuming a 50 percent NPV stock operation during the last quarter of 1996; this operation is applicable to an estimated end-Seplember 1996 pre -cutoff-date debt of USS153 million to Paris Club creditors (NPR and PRD-NC), and commercial creditorn (NPR).

2/ Bauxite and alu wina expon prices are assumed to be 10 percent lower duriag 1995-2014 than under the baseline scenario.

3/ Ceteris paribus; is particular, assuning no additional adjustment effort.

4/ Non mining company exports ane assuned to be 10 perceat lower during 1995-2014 than under the baseline scenario.

5 / Assumes less concessional terms on new borrowings consistent with a 40 percent grant ele ment (26-year maturity, 6-year grace period, and 4.5 percent interest rale) relative to

a 60 percent grantele ment assuned uader the baselise scesario (26-year maturity, 6-year grace, and 2 percent interest rate). 
SENSITIVITY OF DEBT SERVICE RATIOS TO BAUXITE AND ALUMINA PRICES, NONMINING EXPORTS AND TERMS OF NEW BORROWING, 1994-2014

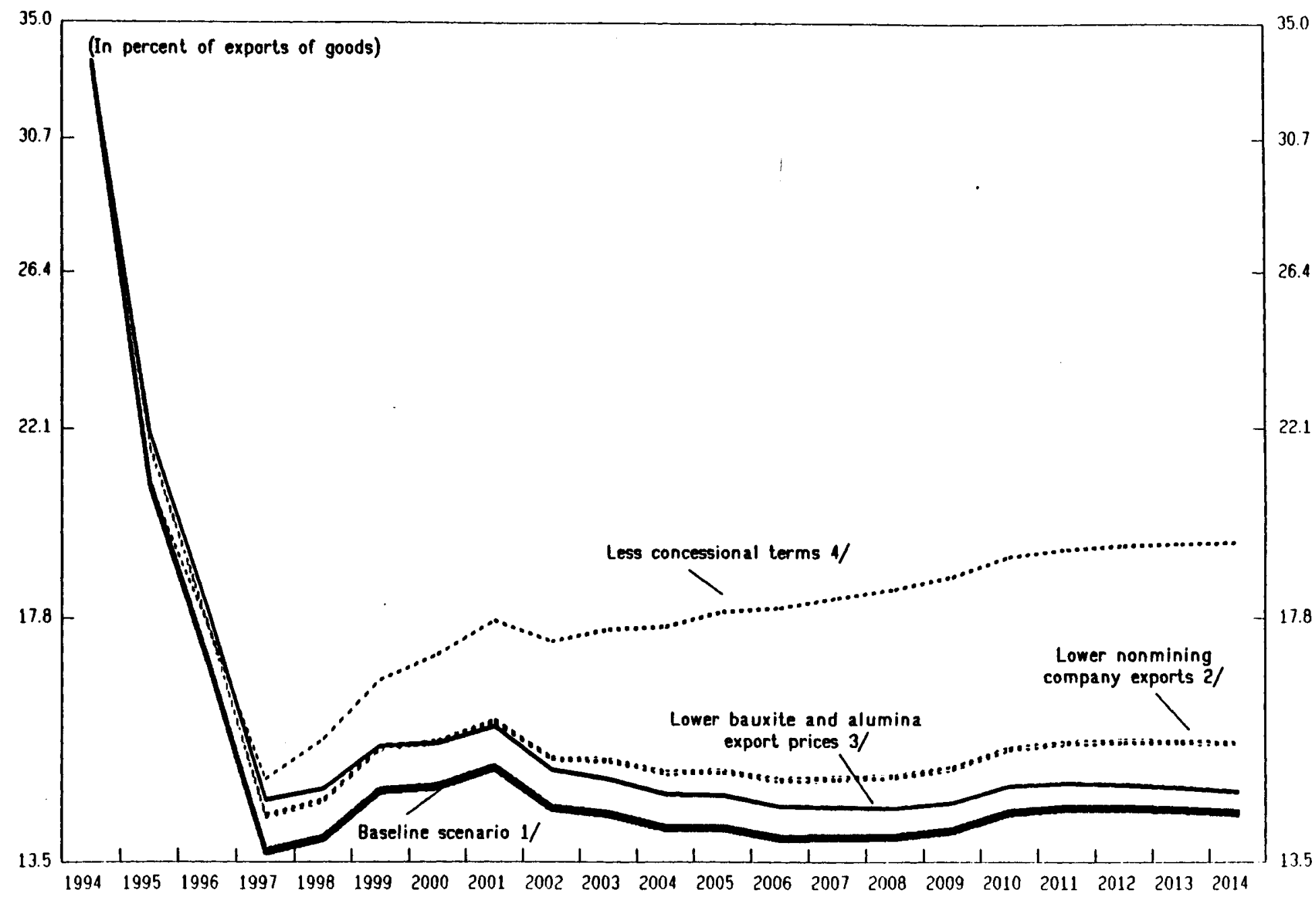

Sources: Doto provlded by the Guineon outhorities.

1/ Assumes o 50 percent NPV stock operalion.

2/ Nonmining company exports are assumed to be 10 percent lower than under the baseline scenario durlng 1995-2014.

3/ Bouxite ond alumino export prices ore ossumed to be 10 percent lower than under the baseline scenario during 1995-2014.

4) Assumes terms of new borrowing consistent with o 10 percent grant element (26-year maturity, 6-year grace period; and 4.5 percent interest rate). 


\section{The Public Enterorise Reform}

\section{Backrround}

Following independence in 1958, the Government of Guinea took over key sectors of the economy. The swift conversion to a socialist state, where public enterprises were the cornerstone of state intervention, was precipitated not only by political factors but also by the need to fill the void left by the departure of foreign advisors and businessmen when official and commercial ties were severed with France. By the early 1980s, at the end of the First Republic, Guinea had a huge and inefficient public enterprise sector, consisting of nore than 200 enterprises, which had been estabilshed under a wide variety of legal forms and were operating in all sectors (Table 1); they accounted for about 75 percent of modern sector employment, 92 percent of total domestic credit, and 38 percent of GDP. 1 Except for the enclave of mining enterprises, whose majority equities were foreign owned, the overall performance of the sector was weak and characterized by low productivity, high losses, mounting arrears, rising debt burden, 1lilquidity, and reliance on monopoly privileges. This weak performance, which was aggravated by mismanagement, lack of accountability, and government interference, led to increasing budgetary support and caused a drain on domestic bank resources.

At end-1985, in the framework of a comprehensive economic and financial program aimed at introducing a market economy in Guinea, the new Government that had taken power in Apr11 1984 launched a reform of the public enterprise sector. During the past decade, considerable progress has been made in downsizing the sector and in improving its performance. This process took place in two phases: a first wave during 1985-88, which was characterized by hasty enterprise closures and sales, and a second wave, which effectively started in 1992 and focused more on institutional reforms with World Bank assistance.

\section{The first phase. $1985-89$}

At end-1985, as part of a significant change of policy in favor of a market-oriented economy and with a view to easing the burden on public finances, the Government Initiated the first wave of liquidations, accompanied by the introduction of divestiture measures in the following months. With the support of multilateral and bilateral donors, 2/ the Government's first wave of divestitures succeeded by 1989 in siashing the size of the public enterprise sector from 234 to 35 , through the

1) Information on the public enterprise sector in Guinea is sketchy; this section is based on partial data collected from a variety of sources.

2/ World Bank, Caisse Française de Développement, and technical support from Industrial Development Center and the United Nations Industrial Development Organization. 
privatization of 33 public enterprises, and the closing down or restructuring of 166 public enterprises (Table 2); the sector's work force was trimmed by 50 percent and its share in total GDP was nearly halved (to 20 percent in 1990).

The public enterprise sector reform process was officially set in motion with the President's address to the nation on December 22, 1985 and started with the liquidation of the banking sector the next day. To this end, the Government adopted two ordinances in December 1985 that authorized the closing down and divestiture of an initial group of enterprises. 1/ In March 1986, a third ordinance was issued, creating the Financial and Economic Coordination Committee (FECC) and empowering it to implement and monitor the economic reforms introduced by the Government in cooperation with the international financial institutions. 2/ Enabling legislation for these three ordinances was passed in October 1986 and provided the foundations of the restructuring of the commercial sector and the regional enterprises. $3 /$

At the top of the institutional framework for the initial divestiture process was the office of the President of the Republic, the sole decisionmaking organ. Below it was the Council of Ministers, which carried out the policy of divestiture. The implementation and monitoring of the reform program was done by the FECC. Technical work was performed by six working groups, the National Commission on Liquidation (NCL) under the authority of the Ministry of Plan and Cooperation, and a subcomission on privatization headed by the Secretary of state for transportation. 4/ The latter was given the authority to review buy-out proposals and award bids.

1) In the absence at that time of a legislative branch, legislative power was exercised by the Presidency in the form of ordinances. Ordinance $306 /$ PRG/85 was published after December 22, 1985 to prevent resistance to the liquidation of the banks, and authorized the liquidation of 12 enterprises: Conserverles de Mamou, Usines Modernes de Conakry, IGAT, Société de Fabrication de Bougles, Briquetterle Nationale de Kobaya, Société de Montage de Véhicules Automobiles, Huilerie de Kassa, Usine céramique de Matoto, Panneaux Seredou, Complexe Sucrier de Bagna, Marais Salants, et Gari Kindia. Ordinance 318/PRG/85 authorized the divestiture of seven additional enterprises, of which five were to be privatized: SOPEC, Usine d'Oxygene et d'Acetylène, Usine de Thé de Macenta, Usine des Meubles de Sonfonia, et Usine de Quinine de Seredou.

2) Ordinance $002 /$ PRG/86 of March 1, 1986.

3/. Decree 194/PRG/86 of October 7, 1986.

4 These six working groups had responsibility for the following areas: industrial restructuring; civil service and administrative reform; nonindustrial parastatal; monetary; credit and relations with primary banks; and establishment of a foreign exchange management plan. 
Divestiture actions in the form of privatization and liquidation were conducted mainly with a view to reducing financial support from the Central Government, easing the insolvency of the domestic banking system, and increasing the role of the private sector. Privatization operations were carried out in several ways: sale of all or part of shares, management contracts, combined restructuring, or employee buyout. I However, weaknesses became evident in this first step of the transition. The reform actions were not sequenced with the other structural reforms (1.e., energy, tariff structure, judicial system) and lacked consistency with the macroeconomic framework, as they were mainly a response to a pressing financial problem. In addition, the divestiture process was impeded by: (i) the absence of an appropriate legal and institutional framework for the divestiture program; (1i) a lack of transparency; (iii) a lack of focus of the policy regarding the divestiture effort and its place within an overall strategy; and (iv) the Government's weak technical capacity. As a result, the reform soon lost its momentum. The divestiture program came to a virtual halt in 1988, but minor efforts continued in 1989.

Although the 199 public enterprises removed from the State's portfolio constitute a very large number, most of the economic and financial objectives of the reform process were not achleved because: (i) few of the privatized enterprises actually remained in operation (11 out of 33); and (ii) the remaining enterprises seem to have been highly protected by generous fiscal exemptions and to have operated in a monopoly or quasimonopoly situation, which implies that signiflcant tax revenues were forgone and that economic efficiency objectives were also sacrificed. Moreover, even if government subsidies were substantially reduced, the net cost to the budget of the divestiture program was sizable, given the need to pay severance compensation to retrenched employees and the accumulated losses taken over by the Government. 2/ Finaliy, despite the relatively low sale prices of the privatized units and the generous payment facilities given to buyers, the recovery of the proceeds was slow. $3 /$ The failure of the privatized enterprises to remain in operation despite this very protected environment was mainly due to lack of management capacity on the part of the investors and to the fact that the physical assets that were sold in the process were so outdated, badly maintained, and otherwise unsuitable that they could not be made profitable even at very low prices.

1 In some cases, enterprises were restructured before privatization, or liquidated and replaced by new enterprises.

2f There is no comprehensive assessment of the cost of the public enterprise reform to the Government. Some elements are given in the main text in the discussion of public finances, in Section III.

3) The-authorities were of the view that these incentives would attract investors wary of the unfavorable business environment that prevailed at that time. 


\section{The second phase 1990-95}

The authorities resumed the public enterprise sector reform in 1990, with World Bank assistance. This new phase included actions that were less striking than those taken during 1985-89, and instead focused more on institutional reforms. In comparison with developments during the first phase, the pace of the reform during 1990-95 was slower, reflecting mainly the reduced size of the public sector in 1990, a qualitative shift in the conduct of the process, and the improved technical preparation of the privatization. A World Bank Public Sector Technical Assistance Project (PATSEP) was approved in 1992. The conditions for the declaration of effectiveness of that loan Included, Inter alia, adopting a new Privatization Law and the enabling decrees, redefining the institutional and legal framework, including Privatization Committee, and issuing a list of public enterprises slated for reform.

\section{a. The institutional and legal reforms}

To strengthen the legal framework, during the second phase the authorities adopted a set of decisions, as shown in Table 3 . The institutional framework was modifled to include a Privatization Commission, which is responsible for helping the Ministry in charge of the State's portfolio to formulate the privatization policy, prepare privatization decisions, and monitor implementation. $\mathcal{W}$ In December 1994, the Government created a new institution within the office of the President, the Administration et Controle des Grands Projets (ACGP) which, in addition to managing large projects, is in charge of conducting and coordinating the restructuring and privatization of the public enterprise sector. 2/ The creation of this new agency has introduced ambiguities in the division of responsibility among different actors--the ACGP, the FECC, the Privatization Commission, and the supervising ministries (ministeres de tutelle).

\section{b. The restructuring actions}

Together with this new legal and institutional framework, the authorities established, in March 1992, In collaboration with the World Bank, a list of some 40 public enterprises slated for privatization. Nearly half of these enterprises had already been partially privatized under the first divestiture program; the second program aimed at selling off all of the Government's remaining shares in these units. The list also included some privatized enterprises that had been repossessed by the Government because investors had defaulted on the fulfillment of the obligations

1) The Privatization Commission is headed by a representative of the Minister in charge of the State's portfollo, two representatives of the supervisory ministry, one representative of the Professional Association of Bankers, and two representatives of the Chamber of Agriculture, Commerce and Industry of Guinea, for the purpose of transparency.

2 Decree D194/167/PRG/SGG of November 30, 1994. 
stipulated in the privatization contracts. Among the remaining units were key public utilities such as ENELGUI (electricity) and SOTELGUI (telecomnunications).

Considerable action has been taken on the enterprises included on the 1992 11st, prinarily in the form of privatization or closure (Table 4). 1 Eight enterprises have been privatized by sales of shares or of assets, by management contracts, or by employee buy-outs; for ten nore, including SOTELGU, the privatization process has been initiated; in addition, three units were restructured and transformed into government units. 2/ The reform conducted during the second wave targeted firms operating in important sectors, such as agriculture (SOGUIPAH), power (ENELGUI), water (SEEG/SONEG), petroleum (SGP), and the food industry (SOBRAGUI). 3/

The conduct of the reform process during this second period was constrained by a number of factors, however, including: (1) a weak database steming from incomplete and irregular flows of information between the public enterprises and the authorities, notably the National Directorate of Public Contracts and Portfolio; (11) the absence of property claims, thus making it difficult to establish the foundations of an equity market; (iii) an institutional framework involving a host of agencies in the public enterprise sector reform, which was detrimental to maintaining the needed confidentiality on related decisions; (iv) limited administrative capacity, as evidenced by a weak judiciel system, and the amount of uncollected proceeds from the sale of assets (GF 4.2 billion); and ( $v$ ) the erosion of confidence that resulted from the accumulation of domestic and external arrears.

\section{Present structure and stze of the public enterorise sector}

On account of the overall reform effort over the past decade, the landscape of the public enterprise sector has changed substantially. At end-July 1995, there were fewer than 60 public enterprises remaining in the State's portfollo, down from more than 200 in 1985 and 68 at

1 As public enterprises were opened to private participation, litigation became means of settling conflicting views among shareholders. Thus, some public enterprises were liquidated on court orders.

2) OFAB, the agency in charge of the infrastructure used by the mining company CBG became the national agency responsible for the design of infrastructural policies for the mining sector as whole (Agence nationale d'aménagement des infrastructures minières - ANAIM); ODDEPAG and OPPA, the artisanal fishing promotion agencies have been absorbed by the Ministry of Fisheries.

3) The former state enterprise DEG was liquidated and two new companies were created, SEEG and SONEG, entrusted with the maintenance and development of equipment, and the distribution of water, respectively. 
end-1991 (Table 5); 1 most of the divestitures took place in the tertiary sector (Table 6). Government ownership is partial in most of the remaining parastatals; the state retains total ownership in only 22 enterprises and veto power in 23 more, but the largest companies are elther under private control or private management.

The most evident results produced by the reform are a leaner public sector, a virtual elimination of the budgetary burden of public enterprises, and an emerging private sector. Competition has been introduced in various sectors (e.g., transport, comerce/distribution, food industry). The economic weight of government-controlled enterprises (neasured by the number of workers) is now highly concentrated in the three mining companies in operation (CBG, FRIGUIA, and SBK). Government participation is no longer significant in manufacturing or agro-industry; of the 17 public enterprises operating in the secondary sector, 5 are not active, 1 is in the process of privatizing management, and the Government has a minority share in 3 others. The Government no longer has a sizable presence in the trading sector, either. 2f In the financial sector, the Government holds $19,51,30$, and 60 percent of the shares in the three banks (BIAG, BICICUI, and BPMG) and the insurance company (UGAR), respectively; and these institutions are all privately managed. Avallable information indicates that operating losses are no longer characteristic of the sector; in 1993, 3 those losses amounted to about GF 5 billion. In addition, budget subsidies are small (GF 3.8 billion in 1994, or 0.1 percent of GDP) and are limited to one company (SOGETRAG); and the sector's share in total bank credit is modest ( 2 percent at end-1994).

\section{Present problems and constraints faced by the public enterprise sector}

There are a number of obstacles to effective reforms remaining in the public enterprise sector in Guinea, including institutional deficiencies, a difficult economic environment, poor management, frequent political intervention, and limited administrative capacity. The legislative and judicial framework is still new (the main privatization leglslation dates from 1993), and the institutions responsible for anaging the state portfolio and the privatization process are numerous and often do not work in harmony. The supervising ministries (ministeres de tutelle) continue to present the central agencies with faits accomplis. Price controls are sometimes imposed, hiring and especially firing decisions are sensitive, and resistance to personnel reductions is very strong.

1 In addition to the privatizetion/liquidation actions undertaken during 1985-88, the authorities created 33 enterprises, mostly during 1989-91, of which 20 were created from previously liquidated enterprises.

2/ Only three trading enterprises remain: DIVERMA and OCR, both small and wholly government-owned, and SGP the petroleum distribution company with 20 percent government ownership.

3/ The last year for which financial data are final. 
At present, the problems of the sector are concentrated in a few enterprises:

(1) SBK, a wholly government-owned mining company, has an oversized work force of about 1,700 and a substantial debt to the Government; it owes FG 1 billion to the Social Security agency, and a plan to release 400 employees in 1995 was held up for lack of budgetary resources for severance payments. The enterprise's main problens are its weak financial position, poor management, fallure to find alternative markets for its bauxite, and low reserves. SBK's financial position has worsened, reflecting deterioration in its external market position: in 1994 sales fell to 1.1 million tons at a price of $\$ 10$ a ton, compared with sales of 2.4 million tons at a price of $\$ 15$ in 1993; the cost of production is about US\$13 a ton. SBK has only about 30 million tons of ore left--enough for 7-10 years of production. A restructuring plan began to be implemented in April 1995.

(2) AREDOR is a large gold and diamond mine with 100 percent government ownership and a work force of about 1,000 . Its operations ceased in September 1994. The previous private partner (Bridge 011 of Australia) quit in 1994, turning its share over to the Government without compensation. This occurred mainly because operating this company required extremely strong security measures, which local people found unacceptable and which proved to be politically impossible to maintain. The authorities have decided to offer the company for sale, or to liquidate it if no investor can be found.

(3) Alr-Guinee, the public alrline company, had an underused staff of about 270 in 1995 , of which 200 are civil servants. It owes arrears to the Social Security agency, to private suppliers to international aviation organizations, and to other alrines. One of 1 ts main aircraft has been Inoperable since May 1994, making it difficult to maintain its domestic services. Under pressure from donors, the Government has launched its privatization. In August 1992 the Societé nationale Air-Guinée was dissolved and replaced by the Socleté Nouvelle Air-Guinée, a company opened to private capital. Tenders for private capital participation were issued without success in February 1993 and in June 1994. 1

(4) SOGUITRO is a road construction and maintenance company that was created in 1990, at the end of the World Bank-sponsored Third Road Project. It has a large stock of equipment and a permanent work force of 112 (445 workers were laid off in 1993). A decree on October 11, 1993 turned SOGUITRO's equipment over to the employees. A commission was named to determine the value of these assets and how they could be paid for. The commission has not yet produced its report, and the company is thus in a

1 In fact, however, Air Guiné's legal status is unclear. The statutes of the Societe Nouvelle Air-Guinée have never been issued, so it legally is still an EPIC. 
unclear legal situation: Its assets are still government owned, and it operates as an independent company (since 1993 it has won five contracts worth about GF 6 bililon, most of them in competitive bidding).

(5) SOGETRAG, a transport company supplying urban bus services in Conakry and interurban services, employs 225 workers, but it has been in a difficult financial position for a long time. A restructuring took place in 1993/94. I SOGETRAG no longer plays a role in suburban transport, which is cheaply and abundantly provided by taxis, minivans, and private buses, but its interurban services are profitable. The company receives operating budget subsidies (GF 3.8 billion in 1994).

The public enterprise sector st111 needs to improve its efficiency. This is to be done through the privatization or liquidation of several enterprises, $2 /$ and the timely implementation of the following recomendations prepared with assistance from the World Bank in the framework of its PATSEP project: (a) a readjustment of the policy of public enterprise reform around stronger role for the Government as a regulator on one side and as the final arbiter of sectoral policy priorities on the other side; (b) the establishment and strengthening of information channels between the public enterprises and the institution in charge of the state's portfolio to create data base in order to improve the technical aspects of the reform process; (c) a revival of the Privatization Commission; (d) the issuance of property claims to all shareholders (private and public) to lay the foundations of an equity market that would strengthen the emerging private sector; (e) the acceleration of the reform of the judicial system; and (f) the provision of social safety outlays for redundancy payments for the retrenched public sector employees.

1 Employment was cut from 946 to 539, tariffs were raised, the taxi fleet was 1 Iquidated, and the bus fleet reduced from 108 to 77 . In May 1995 only 20 buses were operational, all of which were used for suburban routes and charters.

2) The following enterprises have already been included in Guinea's current adjustment program described in the 1995-98 PFP (EBD/95/155): AlrGuinée, AREDOR, CBG, ENELGUI, OFAB, SBK, SOGETRAG, SOGUITRO, and SOTELGUI. Additional enterprises are included in the World Bank's PATSEP project. 
Table 1. Guinea: Overview of the Public Enterprise Sector

Before the Reform by Legal Statute

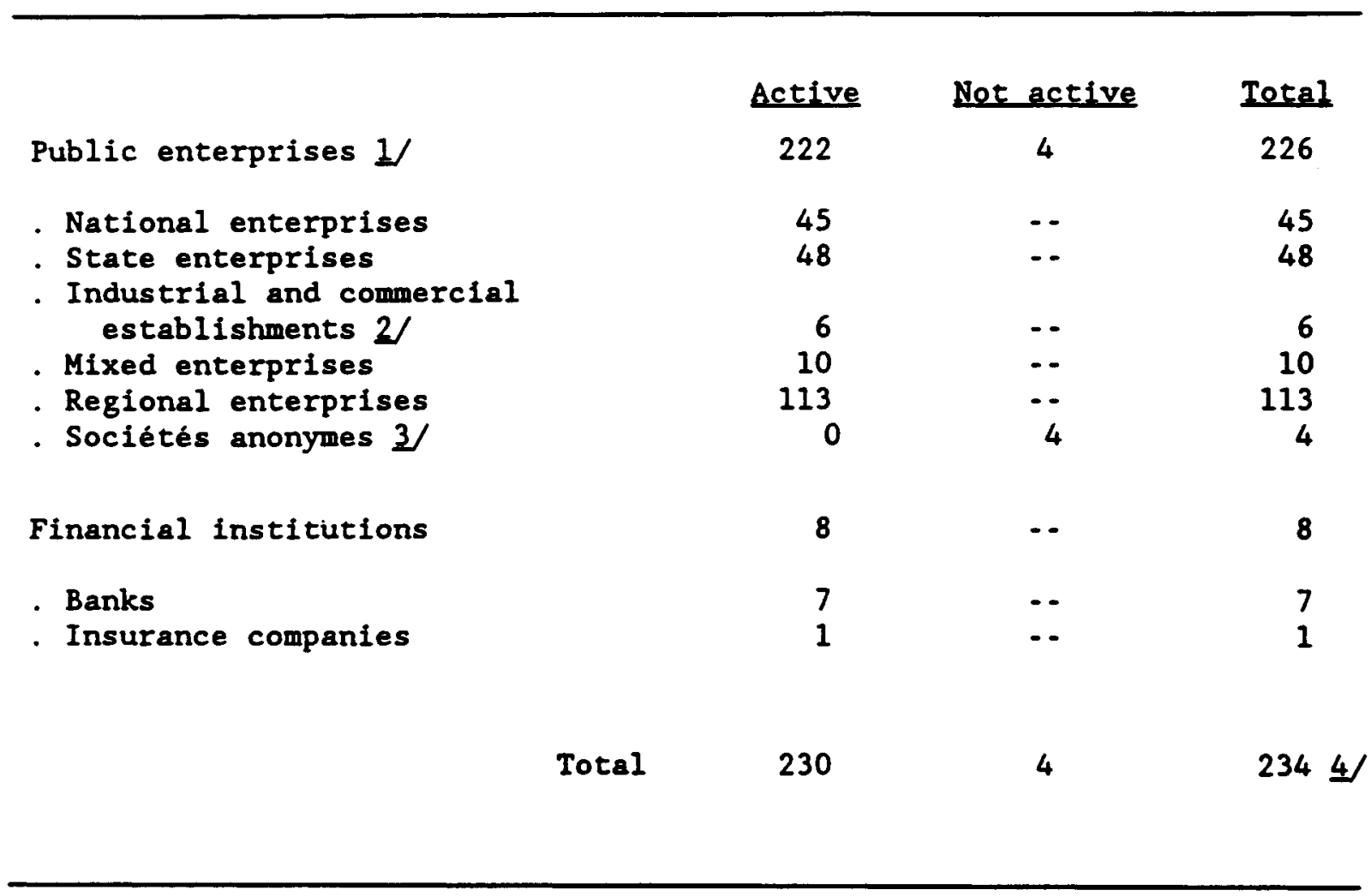

Source: Ministry of Finance.

1 Defined as legal entities that generate the major part of their revenue from the sale of goods and services, and in which the state is the major shareholder.

2) Etablissements publics a caractère industriel et commercial: fully government-owned public enterprises.

3/ Corporate enterprises with partial government ownership.

4/ Of which 14 were in the primary sector (including 9 mining companies), 46 in the secondary sector, and 174 in the tertiary sector. The latter included 34 enterprises involved in trade and 9 in transport/transit activities. 
Table 2. Guinea: Results of the Divestlture Efforts, 1985-95

1. Publle enterprise refor

- Total before reform

- Liquidation 21

- Privatieation

- In stote's portfolle without rehebllitation with rencbilitation

11. Creation of new enterprlses - subsequent to llapulation New creation
$1985.89 y$

$1990-95 \quad 1905-95$

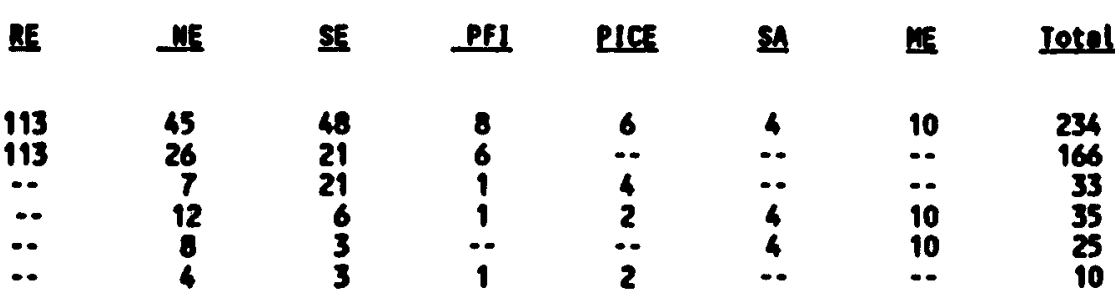

Iotal Iotel

35
6
8
23

23

33

20

Source: Ministry of Finance.

1) RE - reglonol enterprise: ME = notional entreprise; se = state entreprise; PFI - public finenciel institution; PICE = public industrial end

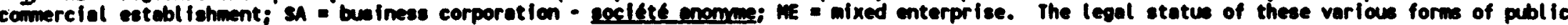
enterprlses was complicated and confusin.

$2 f$ In some ceses. I Iquidation was folliound by the ereation of new public enterprises. 
Table 3. Guinea: Legislation Adopted During 1990-95

Legislative Action

1. Decree $239 /$ PRG/SGG $/ 90$

2. Ordinance $91 / 025 /$ PRG/SGG

March 11, 1991

3. Decree $92 / 133 /$ PRG/SGG

4. Law $293 / 37$

5. Law $293 / 206$

Date enacted

May 26, 1992
November 29, 1990

Reorganized the Ministry of Finance; this included the creation of the National Directorate of Public Contracts and Portfolio, to provide technical support to the divestiture effort and to manage the state's portfolio.

Redefined the overall legal and institutional framework of the re-form; in line with this ordinance, there are now two main forms of public enterprises in Guinea--the public society (societé publique $S P$ ), In which the Government can hold the majority share, or a minority with veto power (at least 33.33 percent of the shares); and the enterprise without veto power (societé sans majorité de blocage. SSMB).

Dissolved the National Commission of Liquidation, and transferred its responsibilities to the National Directorate of Public Contracts and Portfolio within the Ministry of Finance. This decree also called for an audit of the National Commission of Liquidation's activities.

Specified the rules guiding privatization.

Enabled the application of the above.

Source: Information provided by the Guinean authorities. 


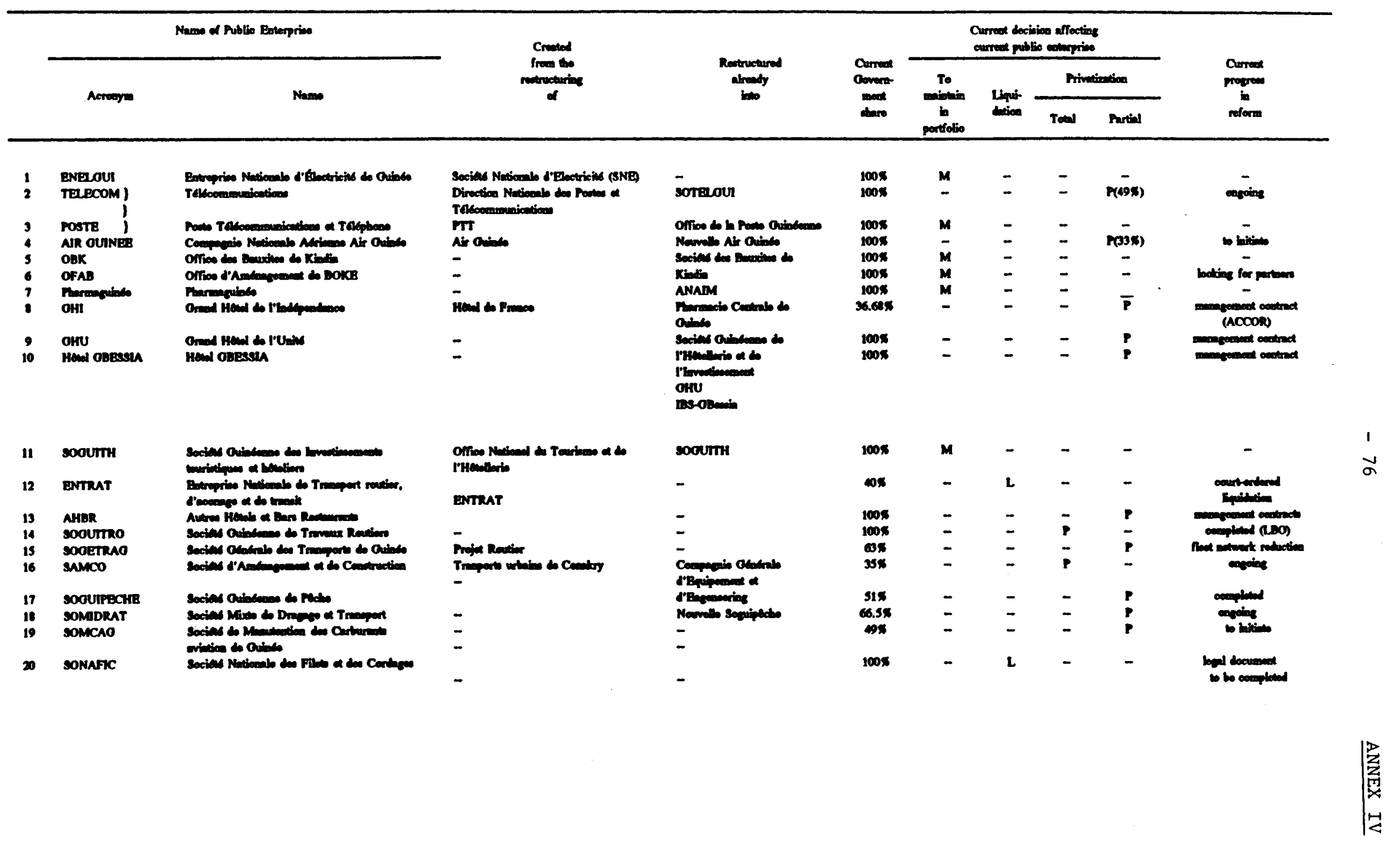


Namo of Publie Enterprien

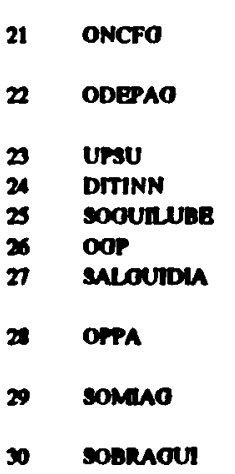

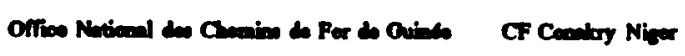

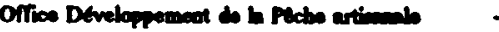
co Ovinte

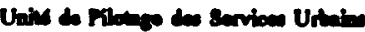

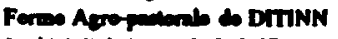

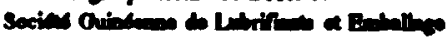

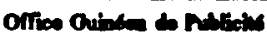

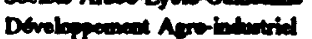

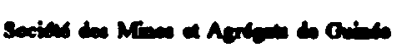

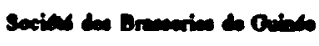

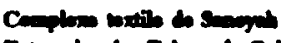

SANOYAH

ENTAO

UMa

SOCUIRAST

Donaour

sorbc

Cinnow on ov

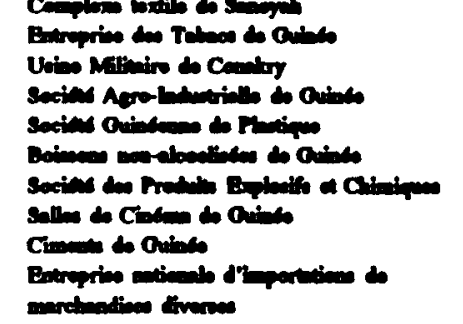$$
-
$$$$
\text { - }
$$$$
-
$$$$
\text { - }
$$

somacao

-

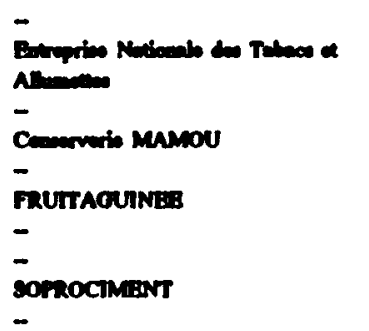

SAMOYAH S.A.

uñOO LTD.

-

somocrma

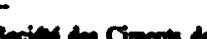

$\operatorname{soc} \cos 200$

$=$

$\begin{array}{ll}41 & \text { FRUTIRX } \\ 42 & \text { OCR } \\ 43 & \text { AORIMA } \\ 43 & \text { SOPROCHIM } \\ 4 & \text { PROSBCO } \\ 45 & \text { SOPAO } \\ 46 & \end{array}$

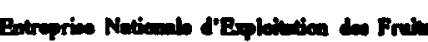
co Ouinde

OMios Chand in Rombillement

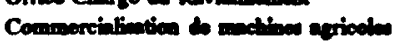

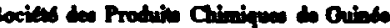

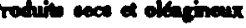

CsPBC

sopec

SIPAR-LABE

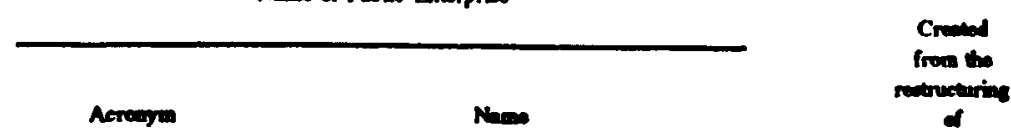

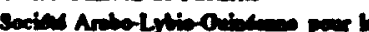

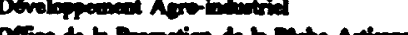

she civen

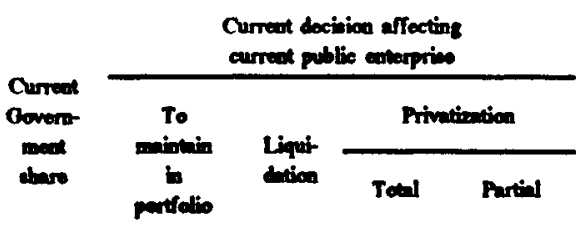

cursed

\begin{tabular}{|c|c|c|c|c|c|}
\hline $100 \pi$ & - & - & - & $\mathbf{P}$ & wo mant io Inom \\
\hline $100 \pi$ & - & - & - & - & adminierentive unit \\
\hline $100 \pi$ & - & - & - & - & 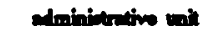 \\
\hline $100 \%$ & - & - & $\mathbf{L}$ & $=$ & 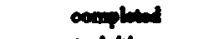 \\
\hline $50 x$ & - & - & - & $\mathbf{P}$ & 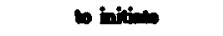 \\
\hline $100 \pi$ & $\mathbf{M}$ & - & - & - & - \\
\hline 25\% & $\mathbf{M}$ & - & - & - & - \\
\hline $100 x$ & $\mathbf{M}$ & - & - & - & i \\
\hline $10 \pi$ & - & - & - & - & 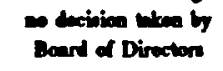 \\
\hline
\end{tabular}

-
$100 \%$
$100 \%$
$100 \%$
$33.35 \%$
$100 \%$

$100 \%$

$10 \%$ 
1. Prinary

Associetion pour le recherche et l'explol tation du disment et de l'or Comparente des bouxites de Guince

mines de fer de cuince

Societe Aurlfere de ruines

Soctete dinquacul ture de tobe

Soctete Arebo-tyblo-cuinterne pour le devel oppenent agro-Industriel

socitete des bouxl tes de Debolo/Touru

societe des bauxites de ocbola/to

sociste miniere de oimoulrave

Soclete Miniere de Dinguiroy

Soclete Guinterme de Peche

socibte des mines et deargeote de culnet

Soclete des olements de cuince

Soclete Mintere de Niende

I1. Secondary
Soclett des ciments de cuince

socilete des produits chimiques de culnte

Complexe Textilee de senoych

Complexe Textiles de senoysh

United Industriel Compeny linited

Entreprise des Tabacs en cuince

Socilte Agro-industrielle de cuince/Manou

societe dimprimerie Potrice lumpe

soclete des Braseerles de cuince

soclete culnterme de Lubrifients et d'embol lages

soclete Guinterne de Palmilere a hulle et héveas

societe mixte de dragages ot de tranoports

societe Mationale des eaux de Gulnee

soclete des plentes eromat laves de cuince

soclete des plentes aromatiques de cuinct

societe de production des Allumettes de Guince

AREDOR
CBG
MIFEREUI
SAG
SAKOBA
SALEIDIA
SBDT
SBK
SND
SOEUIPECHE
SOCUIRUSSE
SOMIAG
SOG
SII

50
49
100
15
59
25
49
100
15
51
15
10
50
50

$\operatorname{sct}$

cTs

CTs

UNico
ENrAG

FRIOUIA

SAIG/MuMOU

SIPL

SOBRAEUI

soeviluBe

SOEUIPAH

somidenat

solveG

SOCUITRO

SOPRAG

not active
octive
active
active
active
active
octive
octive
active
octive
octive
octive
not octive
not active


octive
octive
not octive
not active
not octive
octive
not octive
active
octive
octive
octive
octive
octive
active
active
not octive


Sector Total

26
Union Guinéenne d'Assurances et de Réassurances

Cenque Internotionale pour le Commerce et l'industrie de Gulnce

Banque Populaitre Maroco-Guinetenne

Compognie Mationale Aérierne

Port Autonome de Conakry

Entreprise Mationale d'importation des marchandises diverses

Entreprise Mationale d'slectriclte de Guinee

Entreprise notionale de tranaport rout ier d'aconage et de tranit

societe Guinco-Morveglenne de trensport moritime

Pharmacie Centrale de cuince

Offlice Mational das Chemine de fer de Guince

office charge de ravitaillewent

office Guincen de Publicite

Office National de Cincinatoaraphle de culnce

Office des Postes de Guinte

soclete d'exploitation des Eeux de cuince

Soclete Mavole Guinterne

societe de gestion et d'expleitation de l'aeroport de Conakry

soclete Genérale des tromeports de Guince

societe Guineerne de comstruction

Societe Guincenne des Petroles

Soclete de menutention des carburants aviation de cuince

soclette des tellecomminications de Guinte

soclete Guinterne d'hbtellerle et dinvestissement (Novotel)

socitte Guinterme des invest lseements tourlstiques et hotel fers
Acromm

Goverrment's
shere

Observation

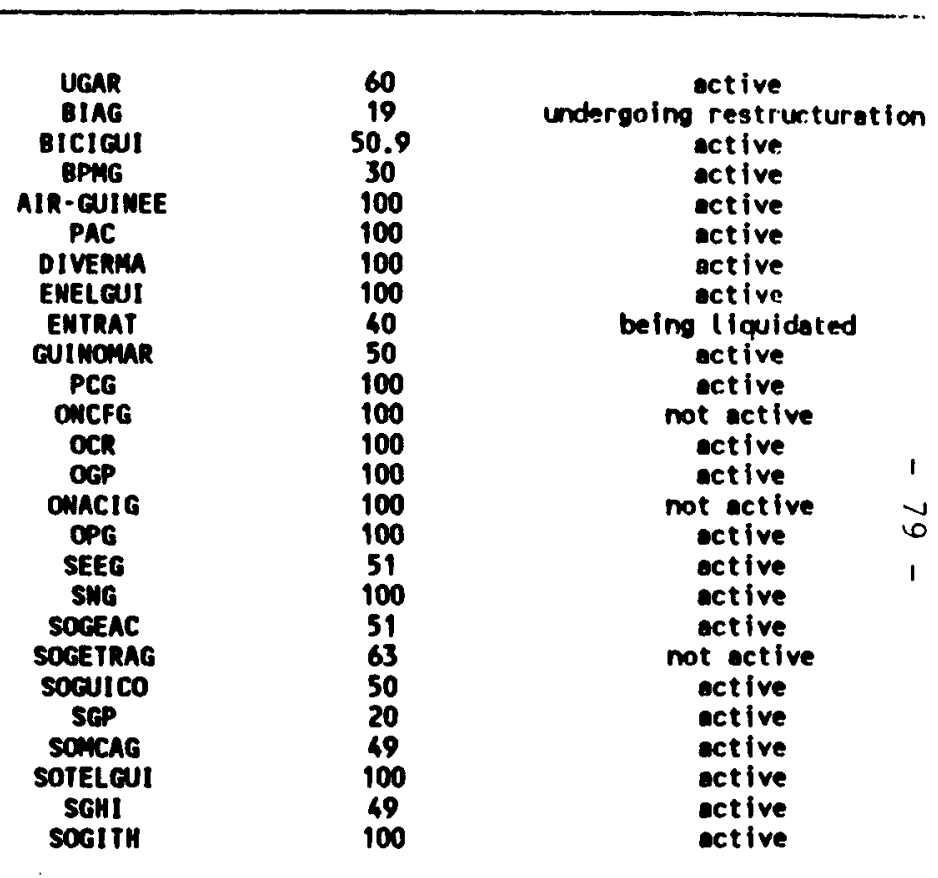

TOTAL $56 y$

of wich: mojorlty shereholders

25

Source: Ministry of Finence.

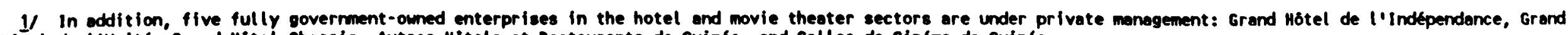
Hötel de l'Unité, Grand Hôtel Gbessia, Autres Hótels et Restaurants de Guinée, and Salles de Cinéma de Guince. 
Table 6. Guinea: Sectoral Distribution of the Divestiture Efforts By the Government, 1985-95

Sectors

Before the reform

14

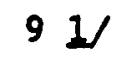

46

174

Tertiary

of which:

commerce/distribution transport/transit

bank/insurance

Total
Public Enterprises

At end-July 1995

Divestiture

\begin{tabular}{|c|c|c|c|}
\hline Primary & 14 & 13 & 1 \\
\hline of which: mining & $91 /$ & 10 & 0 \\
\hline Secondary & 46 & 17 & 29 \\
\hline Tertiary & 174 & 26 & 148 \\
\hline $\begin{array}{l}\text { of which: } \\
\text { commerce/distribution } \\
\text { transport/transit } \\
\text { bank/insurance }\end{array}$ & $\begin{array}{r}34 \\
9 \\
8\end{array}$ & $\begin{array}{l}4 \\
8 \\
4\end{array}$ & $\begin{array}{r}30 \\
1 \\
4\end{array}$ \\
\hline Total & $234 \begin{array}{l}\text { of } \\
\text { p } \\
\text { ge } \\
\text { or }\end{array}$ & 56 & 178 \\
\hline
\end{tabular}

Source: Ministry of Finance.

1) Of which four enterprises were not in operation (SDG, SMD, SMN, SOMIGA). 


\section{Iexes on income and profits}

\subsection{Texes on compentes}

\section{1 .1 Corporete tex} (Impot: sur 108 Soc16t6s - IS (enterprises oporating in Gutnee)

1.1.2 Minimim lump-sum tax (Impot minimum
corfaltelre - IMF)

\subsubsection{Withholding tax} [Rotenue a 1a sourcel

\subsection{Texes on Individuals}

1.2.1 Permonal Income tex [ Impot sur 10 revonu]
Lovied on not income Including capitel selne mede by public and private onterprison ostablishod as jolnt stock coupenies [oociltbe do capltaux] and nonoxempt corporete ont1tion.

Deflefte can be cerried over for a eaxioun of five consecutive elecal yeare.

Tax roturns wast be filed within . four wath period after the ond of the flecel yoar. Presumptive taxation provided for sall businesses.

Annuel tex lovied on turnover sonerated during the prevlous year by coupanies subject to the IS, and laport-export businosses and liberel professions with a turnovar in excess of GF 20 allition. The IMF is not recoverable.

Lump-su tax levied on the gross mount corresponding to servlces of all typos phyelcally provided or uen In Gulnes by corporations having no pereenent professionel lacility in Gulnes.

Lovied on total not Income of individuale realdine or havine their priean occupetion in Gulnee. Sowe priman occupation in Guinea. So wthholding frow the party responsibl for paymont (property Incomo; wages, selartos, and peneions; Income from financial asetes): withholdings are final if there is no other source of incoove.
Asrlcultural supply and procurement cooperatives of the Contral Governpont and Locel Authoritios. Chembers of Cosores, nonprofit essociations. excoptione provided under the Investmont code.

Taxes ostablished with deduction of the Minimum Luop-Sim Tax (1.1.2), and of the tax on vohicles (TUv--5.3.3) for public transportation or freight coupanios.

ow onterprisos (first calondar yoar of activity): specific conventions (०.8. FRIGUIA). 1/

Members of the diplomatic and consular corpe.

Withholdinge are deducted from the personal income tax.
35 percent, excopt epeclel arrangement.

Guinos Bauxite Company (CBG)total asesesent, inclusive of corporate taxes and dividonds. based on grose profits:

85 percent up to US\$100 million. 75 percent for US\$100-150 million, 65 percent for US\$150 million and 65 percent for US\$150 million and
above (1ese the ISPM, see 6.5.1).

Frisu1a: 30 percent. 1'

3 percent, rang Ing between

GF 2 million and GF 20 million.

The IMF ranges botwoen

GF 1 alllion and GF 10 willion for liberal professions.

10 percent.
Prosressive scale of income brackets:

10 percent to 35 percent for 10 porcont to 3s percent GF 20 million; uniform rate of 40 percent applied to incomes in excess of GF 20 million. 


\subsubsection{Withholding tax on wage income lRetenue a 1 . source sur traltconente ot coletros]}

1.2.J Withholding on nonwage incoene pald to nonresidents IRotonue a 10 cource sur les

rovonus non

celariaux verabe dos non rosidentel

1.2.4 Tax on Individual buelnesses I Iupot our les benbfices Industriols ot comenerciaux]

1.2.5 Tax on non comerciel proflt I Impot sur los bensfices non conourel aux]

1.2.6 Tax on Plnanclal roturns lImpot sur les revenue dee capltaux coblliorsl

1.2.7 Tax on non proloselonel capital geine IImposition dos plun-values incoblilires non proLessionnolles]

\section{Soctel ecurtity contribution}

Levied on weges, salarles, and ponstons as part of incose (under 1.2.1) of Individuals residing or havins tholr primary occupation in

Guinee. Pald wonthly or quarterly by the auployer.

Lump-eum tax lovied on the srose count corroeponding to envices of all types physically provided or usod In Guines.

Lovled on not Incose Including capitel gaine sade by Individual businesese not subject to the IS.

Levied on not Incoms of liberal profeselons and other sall businesses profoselons and other san GF 2 illlion. Presumptive taxation provlded for businesses with turnover under GF $20 \mathrm{million}$.

Withholding tax loviod on roturns on fixed torm ardinge, t-bille, and inventents in stocks and shares.

Lovied on the gein in velue ot the anle or tremefer of private lamoveble property by non profenelonal omers.
Member of the diplomatic and coneular corpa.

Does not apply to femily allowances, and soverance pay. Doses not apply to celaries pald to military personnel.

Idem as under 1.1.2

30 percont (20 percent for craftemon)

30 percent

Interest on bank dopon1ts, with eaturities in excess of three wonths. carned by domestic Investors.

Investors in esriculture, Industry. aning, and trade.

Doee not epply to companies subject to Is under 1.1.1. oxcess of GF 2 million).
Progresstre scale of income brackets:

10 percent to 30 percent for Geome between GF 30,000 and

10 percent.
1.50 porcent. 


\section{Parroll taxes}

3.1 Apprenticeship tax (Texe d'epprentissege - TAl
Annual tax payable by employers on the total amount of wages, salaries, and other benefits pald in cesh or in kind. Applicable whon tex base 1 is in excese of GF 300,000

\subsection{Lump-an payroll tax (Voramont forfaltalre sur 10a salalres - VF}

\section{Texes on property}

4.1 Tax on developed property [Contribution fonclare su les propristis baties]

\subsection{Housing tax (Taxe} d'habitetion - TH]

4.3 Tax on undeveloped proporty lContribution proporty IContribut EInancidre sur les
propribtes non blties]

4.4 Tax on melnmorte property (Taxe sur les bione de meinmorte] fandly ellowances. Payable wonthly or
Stotlar to 3.1 lese doduction of quarterly.

Annual tax loyted on housing units or industrial and commerclal

instelletions based on the rentel value stated by a lose or assossed by coopartson.

Tax peld annuelly by the occupants of a houlng unit besed on the rontel value stated in a lease or esseased by comperison.

Annuel tax levied on the market value of the undeveloped real estate.

Annuel tax lovied on resl estate properties owned in perpetulty by religlous Institutions or corporations, which cannot be sold or transforred.
Exemption: As follows:

Excoption provided under the

Investment Code or specific

conventions;

Employers heving opprenticeship progrums:

Employers subject to the contribution to finance continuing vocational

tralning:

Contrel Governont and Local

Authorit1 os.

Contral Governmont and Locel Authoritios.

Appliceble to 60 percent of the rentel velue of houses and to

so percent of the rentel value of factories. A 50 percent discount is granted to owner-occupents.

Excoptions for properties owned by the Contral Government or used for educationel, relistous, or social purposes.

GF 15,000 is subtracted from the rental velue for owner-occupants, and GF 10,000, in seneral cases. Propertices used for educational, modical, or social purposes, or by this tax.
6 percent.

3 percent.
10 percent for net income of under GF 300,000;

15 percent for net income of GF 300,000-GF 1,000,000; 20 percent for not income of more than GF 1 alllion.

\section{0 percent}

\section{1 percent}

Rel1s lous institutions: 0.20 percent of the value. Corperations and other entities: $0.5 n$ i rcont of the anount due for the pl :purty tax applicable to developed propertios. 
4.5 Inheritance and slft tax (Drolte de euccesaton ot donetion]

Lovfod on the trensefor of movable or inoveble property without veluable consideration. d'enresietremont]

\subsubsection{Corporate ect toos} (Drolts sur los ectes des socibtbs

Leviod on eapital Increanes. contributions, and lorretion.

Asesseed on the capltal or mount of

\subsection{Rocistration Leos CDrolte} the contribution.

\author{
4.6.2 Aseisment of \\ corporate shares or \\ stocke ICessione de \\ parts ou d'ections \\ de socistbs] \\ 4.6.3 Tax on tranefor of \\ movable property
(Drolte freppent 10 \\ (Drolte freppant 1 \\ noublos] \\ 4.6.4 Tax on trensefor of \\ Inuovable property \\ lDrolte frappent 10 \\ trenefort de blene \\ Irmenubles] \\ 4.6.5 Tax on capitel \\ calne ITaxe de \\ plus-values \\ Tax levied on the value of the \\ property transforred. \\ Levied on the cele or rentel of \\ covable property. \\ Levied on the eale, rental, or \\ exchange of Innoveble property. \\ Lovied on the gein in value ot the \\ sele or trenefor of limovable \\ property.
} Iunobilidreal
GF 30,000 ellowance. Conventions excopt some coupentes
(e.8. FRIGUIA). $y$

(n)

Excuptions in case of morger of epecietc companies.
Variable scale depending on the dogree of emolly relationship between the donor or the deceased and the rectplent or heir.

Comperciel enterprisos: Formation and Increase in capital by contribution: 2 porcont: Increase In capltel by copltalisation of reserves or by mereer: 5 percent; mereor: I percent;

Induatrial onterprises: up to GF 500,000,000: 0.50 percent: GP $500,000,000$ and above: 0.25 percent.

10 percent.

Sales: 10 percent;

Rentels: 2 poreent.

Sales: 10 percent;

Rentel (1imited term: 2 percent); Rental (unlimited torm: 10 porcont).

25 percent of the gein. 
Gulnea: Summary of the Iax Syatem (continued)

(As of October 31, 1995)

Tax
Sterup tax on public

contract: (Drolt de timbre

wur los marchis publice]
Tax to be peid by the holders of public contracte entered into with the Contrel Governeont or Local Authorities. Asseseed on the totel price of the contract.

5. Texes on soods and services

\subsection{Turnover texas}

\subsubsection{Production tax ITaxe 10 production!}

\section{S.1.2 Businese tax (Taxe} sur los effelres

\subsection{Spectel producte}

Fiscal surcharse [Surtaxe Elscale]

\section{Tax to be patd by locel producera} besed on sross revenue.

Levied on importers, tredors, and cervice providers, besed on eross revenue.
Specific tex on beer, alcohollc beveragen; ad valorem tex lovied on the tax-excluedve eele price of vireinia tobacco.

\subsection{Iex on the yee of soods of} propertles

5.3.1 Business and
professional
11cense tax
[Contribution dos
patentes]

Annual tax paid by Individuale and corporations ongeged in coumercial. induatriel, or ext1sanel activities. or liberal profession. Collected by locel ontitios.
Deduction of turnover tares pald on purchases or imports of rem materials or Inputs and on electricity and weter.

Exemtions: exporte, foodatuffe, and nomuprint.

Ho deductione.

Excoptions: exports, soods subject to payent of limport duty; seles of foodetuffe.

\section{Excomptions:}

Artieans heving a maximum of one coployos;

Sociel and educationel activities. 50 percent tax reduction for Industrial onterprises.
13 percent.

Lum-sum tax

steaup:

and proportional tar:

GF 1-10 million: 1 percent;

GF 10-100 million: 0.5 percent: GF 100-1,000 million: 0.25 percent

Over GF 1 blllion: 0.1 percent.

Sale for on-site consumption:

15 percent;

Other selos and services: 13 percont;

Insurance and telecommenlcations:

10 percent:

Wator and electricity

distribution: 5 percent.

Non-alcoholle beverages: GF 10 per bottle or can up to $50 \mathrm{cl}$, or per 11tre; GF 15 for quantities exceeding $50 \mathrm{cl}$.

Alcohollc bevereges: GF 20 per bottle or can up to $50 \mathrm{cl}$. : GF 30 for quantities exceeding $50 \mathrm{cl}$. or per litre.

Tobecco: 10 percent.

The tex comprises of a fixed fee, which varies (GF 60,000-5 million) depending on the activity, and proportional foe of $10-15$ percent levied on the estimated rental value of the professional premises (0.7 percent of the market values). 
5.3.2 Liconse fees [Contrlbution des (1)ences]

5.3.3 Tax on vohicles ITaxe untque sur les vonicules TUV!

\subsection{Other locel texes:}

\subsubsection{Boad tex lIapot Animur pour 10 developpeant \\ locall}

5.4.2 Tax on Elre eres

6. Toxes aseesend by the Nationel Customs Adminictration

\subsection{Impert foes and texes}

\subsubsection{Ioport dut1es [Drolts de doueno ['ontres - DDE]}

Annuel tex which must bo pald by Individuele and corporations ovllins elcohollc or formented boverages. collocted by locel ontitios.

Annuel fee levied on motor vehlclea and pleanure boets. 25 percent of the tax it elloceted to local entitioe.

Excopt lone:

Diplomatic corpa vehiclos:

Vohtcles owned by the Centrel

Government or Locel authoritiea

vohtcles owned by the arwed forces.

Amiual head tex pald by Individuale eged 14 to 60 residing In Gulnoe. Collocted by locel ontities.

Annuel tax paid by holders of tire arms. Collocted by locel ontities.
Excoupted: the poor, students, civil cervant: and the militery.

Excmpted: Mellers of I1re arwa; armo used for sport or illitery training.
Foe of GF 15,000-150,000 depending on the type of beverages sold and dependins on whether the beverages are coneuned on the premises.

Specific rate of GF 5,000 for mopede to GF 450,000 for hoevy trucks.

GF 2,000 per person.

GF 225-2,000 per weapon dopending on the callber.
6.1.2 Flecel loport dut1es IDrolt ciacel a l'ontr6o -

DFE)

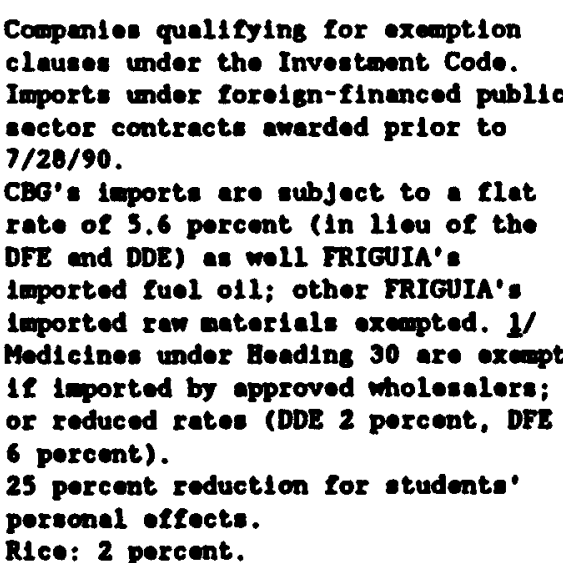

Other excouptions as for the DDE.
7 percent.

- percent.
Besed on c.1.1. value of soods.
CInternational Monetary Fund. Not for Redistribution 


\subsubsection{Consumption surcharse surcherse
[Surtexe de consommation-SC]}

\subsection{Export teen and texes}

\subsection{Other foes and texes}

\subsubsection{Tranalt foo lDrolt}

6.1.3 Turnover tax ITexe sur 10 chiffre d'affal res - TCA]

Fiecel export dutios

[Drolt fiacel do sort1e DFs! de traneit - DTI

Tax levied on the value of imports (Inclusive of DDE, DFE, RTL, and other Import toos).

Surtex on luxury itens

Taxes on exporte.

Applicable to unused merchandise subject to cuntose in International tranalt.

6.3.2 Sealing tee, Storage toe [Drolt de plombere, drolt de plombese, drolt

6.3.3 Custome roglatration tax (Texe

6.3.4 Tex on re-exporte (Taxe do róxportation rérpor proceselng toe tRodevence do tralt monent ot do [lquidation - RTL]

6.3.6 Warohoule tex ITaxe d'entreposege TE:]

Levied on projecte benefiting from the investmont codo (f,o.b. value).

epplies to the R.0.b. value of

leeves the warehouse.

Levied on all Inported soods.

All goods ontering warohouses.

Applites to the c.e.f. value of the goods at the date on which thor leave d'enregletrement on douneses - IEI

6.3.5 Assensement
Other exemptions es for the DDE.

Excons provided under the Investment Code.

Mixed mining compantes.

Excoptions for egricultural products and locally produced industrial products, including elumina.
13 percent.

12 percent for rice

Variable rates.

Beer and alcohollc beverages:

60 percent;

Vohicles: 20-30 percent.

dopending on ons lne capactity.
2 percent.

2 percent.

Amount varies depending on the nature of the parcel and length of t1me (more or less 30 days) in storage.

0.50 percent.

\section{2 porcent.}

Does not apply to cubassies, technicel aseistence under externel Innance; personal effocts of NGO': ared minlng companies.

1 percont. the warehouse. 
6. eatertele

\subsection{Iex on elinime products}

\subsubsection{Speclel tax on minlng products ITaxo epteialo eur \\ les produlte}

alnier: ot

dorivise - TSFM

6.5.2 spoctefe tax on consuriod baurite ITaxo spicle1que our In beuxit. consocubsol

\subsubsection{Speciel tax on the} turnover of SBK

6.6 In on petroloin products

Special tax on potroleum producto ITaxe eplelale wur los prodults pitrollers - TSPP)

\subsection{Other spectel texes}

Tax on exporte of di amonds, gold and other precloue metal.
Unifled tarlef for loported raw

materlele (Incluelve of DDE, DFE, IE,

RTL and other taxes). Including by

compenles under the Investenent Code.

Lovled wonthly as on edvance paywent

for eseregate taxee and dividends due

by CDO (aseessed by custome, collected

by the Contral Dank). I/

Lovled monthly on the quantity of bauxite uned by FRIeura to produce alunine. $y$

\section{Hithhold by the Ceatrel Bank at the}

tios of poyment for shipoents

Added to dutios, foos and taxos.

Excuptions provided under the Investmont Code: Mixed alning companios;

Forelgn-financed public sector contracts ewarded prior to $7 / 28 / 90$.
12.5 percent.

CBG (bauxito), Us\$8-9 per ton depending on world prices; 1

FRIGUIA (alumina): US\$O.5 por ton of beurite used to produce alumine (about us\$1.75 per ton of produced alunina). 1 (

30 pereent of SBK' turnover

(f.o.b. oxport valuo)
Fixed scalo:

GF 425 for gasolino:

GF 415 for fuel o11:

GF 145 for kerosene:

GF 125 for IF 10 ?uel ofl.
3 percent for dimond

5 percent for gold and other precious eotels.

Source: Deta provided by the Gulnean authoritles.

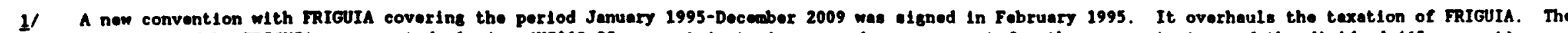

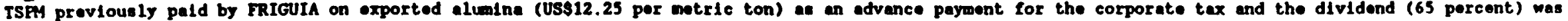

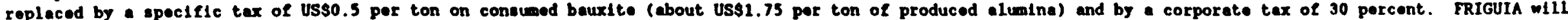

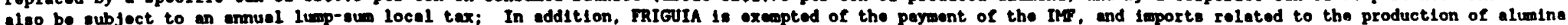
are exempted (except 1mporte of fuel-oll whlch are eubject to e slat teriff of 5.6 percent). The convention will be reviowed overy flve years. 
Table 1. Guinea: Gross Domeric Product, 1988 - 94 y

(Current martet prices)

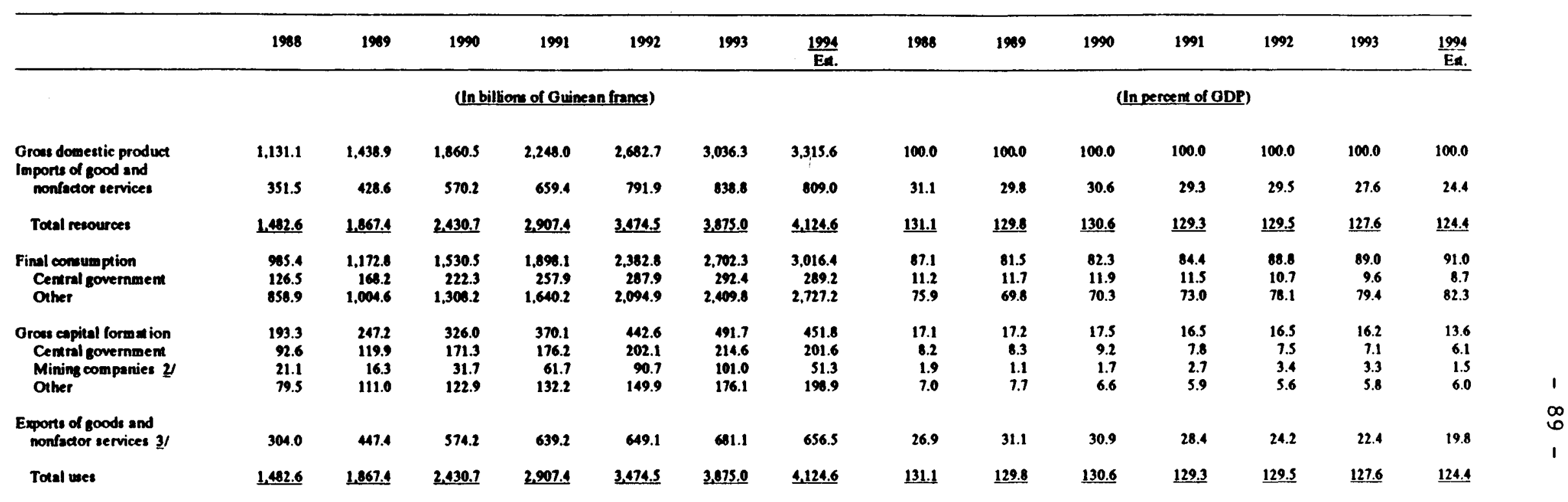

\section{Memoradum items:}

\begin{tabular}{|c|c|c|c|c|c|c|c|c|c|c|c|c|c|c|}
\hline $\begin{array}{l}\text { Oross national savings } \\
\text { Central government } \\
\text { Mining companies } \underline{\text { I }} \\
\text { Other }\end{array}$ & $\begin{array}{r}89.4 \\
15.9 \\
120.6 \\
-47.1\end{array}$ & $\begin{array}{r}177.3 \\
47.3 \\
189.1 \\
-59.0\end{array}$ & $\begin{array}{r}223.1 \\
75.0 \\
220.5 \\
-72.4\end{array}$ & $\begin{array}{r}266.0 \\
73.4 \\
254.7 \\
-62.1\end{array}$ & $\begin{array}{r}233.8 \\
109.0 \\
226.6 \\
-101.8\end{array}$ & $\begin{array}{r}279.8 \\
99.3 \\
231.2 \\
-50.7\end{array}$ & $\begin{array}{r}261.7 \\
81.8 \\
181.1 \\
-1.2\end{array}$ & $\begin{array}{r}1.9 \\
1.4 \\
10.7 \\
-4.2\end{array}$ & $\begin{array}{r}12.3 \\
3.3 \\
13.1 \\
-4.1\end{array}$ & $\begin{array}{r}12.0 \\
4.0 \\
11.9 \\
-3.9\end{array}$ & $\begin{array}{r}11.8 \\
3.3 \\
11.3 \\
-2.8\end{array}$ & $\begin{array}{r}8.7 \\
4.1 \\
8.4 \\
-3.8\end{array}$ & $\begin{array}{r}9.2 \\
3.3 \\
7.6 \\
-1.7\end{array}$ & $\begin{array}{r}7.9 \\
2.5 \\
5.5 \\
-0.0\end{array}$ \\
\hline $\begin{array}{c}\text { Domexically generated } \\
\text { isvings } 3 / 4 / \\
\text { of which: Goverment }\end{array}$ & $\begin{array}{c}49.8 \\
(-23.7)\end{array}$ & $\begin{array}{c}119.3 \\
(-10.7)\end{array}$ & $\begin{array}{c}156.5 \\
(8.4)\end{array}$ & $\begin{array}{c}183.5 \\
(-9.1)\end{array}$ & $\underset{(-13.3)}{111.5}$ & $\begin{array}{c}167.1 \\
(-13.4)\end{array}$ & $\begin{array}{c}144.3 \\
(-35.6)\end{array}$ & $\begin{array}{c}4.4 \\
(-2.1)\end{array}$ & $\begin{array}{c}8.3 \\
(-0.7)\end{array}$ & $\begin{array}{c}8.4 \\
(0.4)\end{array}$ & $\begin{array}{r}8.2 \\
(-0.4)\end{array}$ & $\begin{array}{c}4.2 \\
(-0.5)\end{array}$ & $\begin{array}{c}5.5 \\
(-0.4)\end{array}$ & $\begin{array}{r}4.4 \\
(-1.1)\end{array}$ \\
\hline
\end{tabular}

Sources: Minixry of Planning and Cooperation; and asff extimates.

1) Including Iransactions with the former Soviet Union.

21 Comprises Compagnie des Bawoites de Guinte (CBO), the Kindia bauvite mine (OBKSBK), Friguia (alumina producer), Arédor (diamond mine), and Socitte Aurifre de Guinte (gold mine - -SAG).

3/ Exports were redefined to include exports of gold by the Central Bank, previously recorded as "wonetized gold" in the capital account. The external current account deficit and gross savings were revised accordingly.

II Gross national savings, minus official grams. 
Table 2. Guinea: Gross Domestic Product, 1988-94 1/

(In constant 1989 masket prices)

\begin{tabular}{|c|c|c|c|c|c|c|c|c|c|c|c|c|c|c|}
\hline & 1988 & 1969 & 1990 & 1991 & 1992 & 1993 & $\frac{1994}{\text { Est. }}$ & 1908 & 1989 & 1990 & 1991 & 1992 & 1993 & $\frac{1994}{\text { Est. }}$ \\
\hline & \multicolumn{7}{|c|}{ (th billions of Guineen (rences) } & \multicolumn{7}{|c|}{ (In percent of ODP) } \\
\hline \multicolumn{15}{|l|}{ Sources and uses } \\
\hline $\begin{array}{l}\text { Orose domeatic product } \\
\text { lisports of good and } \\
\text { nonfector services }\end{array}$ & $\begin{array}{r}1.363 .5 \\
443.6\end{array}$ & $\begin{array}{r}1.438 .9 \\
428.6\end{array}$ & $\begin{array}{r}1.501 .3 \\
470.6\end{array}$ & $\begin{array}{r}1,537.3 \\
472.5\end{array}$ & $\begin{array}{r}1,582.9 \\
460.8\end{array}$ & $\begin{array}{r}1,657.3 \\
488.2\end{array}$ & $\begin{array}{r}1.723 .6 \\
435.2\end{array}$ & $\begin{array}{r}100.0 \\
32.1\end{array}$ & $\begin{array}{r}100.0 \\
29.8\end{array}$ & $\begin{array}{r}100.0 \\
31.3\end{array}$ & $\begin{array}{r}100.0 \\
30.7\end{array}$ & $\begin{array}{r}100.0 \\
29.1\end{array}$ & $\begin{array}{r}100.0 \\
29.5\end{array}$ & $\begin{array}{r}100.0 \\
25.1\end{array}$ \\
\hline Total resources & $1,821.3$ & $1,867,5$ & 1.971 .9 & $2,009.7$ & $2,043.7$ & $\underline{2.145 .5}$ & $\underline{2.150 .8}$ & $\underline{1321}$ & $\underline{129.8}$ & $\underline{131.3}$ & $\underline{130.7}$ & 129.1 & $\underline{129.5}$ & $\underline{125.2}$ \\
\hline $\begin{array}{l}\text { Final consumption } \\
\text { Central govemment } \\
\text { Other }\end{array}$ & $\begin{array}{r}1.163 .9 \\
145.1 \\
1,018.8\end{array}$ & $\begin{array}{r}1,172.8 \\
168.2 \\
1,004.6\end{array}$ & $\begin{array}{r}1,230.1 \\
186.5 \\
1,051.6\end{array}$ & $\begin{array}{r}1.264 .7 \\
190.5 \\
t .074 .2\end{array}$ & $\begin{array}{r}1,334.2 \\
196.9 \\
1,137.4\end{array}$ & $\begin{array}{r}1,361.5 \\
195.1 \\
1,166.5\end{array}$ & $\begin{array}{r}1,444.4 \\
190.8 \\
1,253.6\end{array}$ & $\begin{array}{l}84.1 \\
10.5 \\
73.6\end{array}$ & $\begin{array}{l}81.5 \\
11.7 \\
69.8\end{array}$ & $\begin{array}{l}82.5 \\
12.4 \\
70.1\end{array}$ & $\begin{array}{l}82.3 \\
12.4 \\
69.9\end{array}$ & $\begin{array}{l}84.3 \\
12.4 \\
71.9\end{array}$ & $\begin{array}{l}82.2 \\
11.8 \\
70.4\end{array}$ & $\begin{array}{l}83.8 \\
11.1 \\
72.7\end{array}$ \\
\hline $\begin{array}{l}\text { Orous capital formation } \\
\text { Centril govemment } \\
\text { Mining companiet } y \\
\text { Oher }\end{array}$ & $\begin{array}{r}241.2 \\
115.8 \\
26.0 \\
99.4\end{array}$ & $\begin{array}{r}247.2 \\
119.9 \\
16.3 \\
111.0\end{array}$ & $\begin{array}{r}265.9 \\
140.0 \\
25.4 \\
100.5\end{array}$ & $\begin{array}{r}2624 \\
1261 \\
41.7 \\
94.6\end{array}$ & $\begin{array}{r}259.7 \\
120.6 \\
49.6 \\
89.4\end{array}$ & $\begin{array}{r}281.1 \\
124.2 \\
55.0 \\
101.9\end{array}$ & $\begin{array}{r}243.6 \\
1120 \\
21.0 \\
1105\end{array}$ & $\begin{array}{l}17.4 \\
8.4 \\
1.9 \\
7.2\end{array}$ & $\begin{array}{r}17.2 \\
8.3 \\
1.1 \\
7.7\end{array}$ & $\begin{array}{l}17.7 \\
9.3 \\
1.7 \\
6.7\end{array}$ & $\begin{array}{r}17.1 \\
8.2 \\
2.7 \\
6.2\end{array}$ & $\begin{array}{r}16.4 \\
7.6 \\
3.1 \\
5.7\end{array}$ & $\begin{array}{r}17.0 \\
7.5 \\
3.3 \\
6.1\end{array}$ & $\begin{array}{r}14.1 \\
6.5 \\
1.2 \\
6.4\end{array}$ \\
\hline $\begin{array}{l}\text { Exponts of gooda and } \\
\text { nonfector servicet } 3 /\end{array}$ & 4222 & 447.4 & 467.9 & 4826 & 4498 & 5028 & 470.8 & 30.5 & 31.1 & 31.2 & 31.4 & 28.4 & 30.3 & 27.3 \\
\hline Total user & 1.827 .3 & $1,867.5$ & $1,971.9$ & $2,009.7$ & $\underline{2043.7}$ & $\underline{2.145 .5}$ & $2,158.8$ & $\underline{1321}$ & 129.8 & $\underline{131.3}$ & $\underline{130.7}$ & $\underline{129.1}$ & $\underline{129.5}$ & $\underline{125.2}$ \\
\hline \multicolumn{15}{|l|}{ Compocition } \\
\hline $\begin{array}{l}\text { Primary sector } \\
\text { Agriculure } \\
\text { Livestod } \\
\text { Fisheries } \\
\text { Foreaty }\end{array}$ & $\begin{array}{r}3220 \\
230.8 \\
40.6 \\
6.9 \\
43.5\end{array}$ & $\begin{array}{r}339.2 \\
241.4 \\
47.1 \\
7.1 \\
43.5\end{array}$ & $\begin{array}{r}350.7 \\
246.7 \\
49.0 \\
8.2 \\
4.9\end{array}$ & $\begin{array}{r}363.2 \\
2564 \\
51.0 \\
9.6 \\
46.3\end{array}$ & $\begin{array}{r}377.0 \\
264.8 \\
53.3 \\
11.0 \\
47.9\end{array}$ & $\begin{array}{r}395.8 \\
272.1 \\
55.7 \\
12.7 \\
49.4\end{array}$ & $\begin{array}{r}415.7 \\
2920 \\
58.2 \\
14.6 \\
51.0\end{array}$ & $\begin{array}{r}23.3 \\
16.7 \\
2.9 \\
0.5 \\
3.1\end{array}$ & $\begin{array}{r}23.6 \\
16.8 \\
3.3 \\
0.5 \\
3.0\end{array}$ & $\begin{array}{r}23.4 \\
16.6 \\
3.3 \\
0.5 \\
3.0\end{array}$ & $\begin{array}{r}23.6 \\
16.7 \\
3.3 \\
0.6 \\
3.0\end{array}$ & $\begin{array}{r}23.8 \\
16.7 \\
3.4 \\
0.7 \\
3.0\end{array}$ & $\begin{array}{r}23.9 \\
16.8 \\
3.4 \\
0.8 \\
3.0\end{array}$ & $\begin{array}{r}24.1 \\
16.9 \\
3.4 \\
0.8 \\
3.0\end{array}$ \\
\hline $\begin{array}{l}\text { Secondary ecetor } \\
\text { Mining } y \\
\text { Manufycturing } \\
\text { Water, electricity } \\
\text { Construction }\end{array}$ & $\begin{array}{r}462.2 \\
306.7 \\
62.1 \\
3.1 \\
60.4\end{array}$ & $\begin{array}{r}477.6 \\
3220 \\
64.0 \\
3.3 \\
68.4\end{array}$ & $\begin{array}{r}491.7 \\
322.6 \\
67.2 \\
3.3 \\
98.5\end{array}$ & $\begin{array}{r}4964 \\
320.7 \\
69.9 \\
3.4 \\
102 .\end{array}$ & $\begin{array}{r}499.6 \\
315.9 \\
71.8 \\
3.4 \\
108.4\end{array}$ & $\begin{array}{r}515.0 \\
322.2 \\
75.4 \\
3.6 \\
113.8\end{array}$ & $\begin{array}{r}531.4 \\
328.6 \\
79.6 \\
3.7 \\
119.5\end{array}$ & $\begin{array}{l}33.4 \\
22.3 \\
4.5 \\
0.2 \\
6.4\end{array}$ & $\begin{array}{r}33.2 \\
22.4 \\
4.4 \\
0.2 \\
6.1\end{array}$ & $\begin{array}{r}32.8 \\
21.5 \\
4.5 \\
0.2 \\
6.6\end{array}$ & $\begin{array}{r}32.3 \\
20.9 \\
4.5 \\
0.2 \\
6.7\end{array}$ & $\begin{array}{r}31.6 \\
20.0 \\
4.5 \\
0.2 \\
6.8\end{array}$ & $\begin{array}{r}31.1 \\
19.4 \\
4.6 \\
0.2 \\
6.9\end{array}$ & $\begin{array}{r}30.8 \\
19.1 \\
4.6 \\
0.2 \\
6.9\end{array}$ \\
\hline $\begin{array}{l}\text { Tertiary sector } \\
\text { Trade } \\
\text { Transpon } \\
\text { Adminiatration } \\
\text { Other }\end{array}$ & $\begin{array}{r}572.5 \\
331.9 \\
71.6 \\
91.0 \\
70.1\end{array}$ & $\begin{array}{r}393.5 \\
347.1 \\
72.2 \\
96.1 \\
78.1\end{array}$ & $\begin{array}{r}6261 \\
3669 \\
75.6 \\
101.6 \\
82.0\end{array}$ & $\begin{array}{r}643.0 \\
381.6 \\
78.4 \\
96.8 \\
86.1\end{array}$ & $\begin{array}{r}669.5 \\
399.2 \\
81.7 \\
97.8 \\
90.8\end{array}$ & $\begin{array}{r}707.4 \\
423.1 \\
85.0 \\
92.9 \\
106.4\end{array}$ & $\begin{array}{r}730.8 \\
448.5 \\
88.4 \\
91.3 \\
102.6\end{array}$ & $\begin{array}{r}41.4 \\
24.0 \\
5.2 \\
6.6 \\
5.6\end{array}$ & $\begin{array}{r}41.3 \\
24.1 \\
5.0 \\
6.7 \\
5.4\end{array}$ & $\begin{array}{r}41.7 \\
24.4 \\
5.0 \\
6.8 \\
5.5\end{array}$ & $\begin{array}{r}41.8 \\
24.8 \\
5.1 \\
6.3 \\
5.6\end{array}$ & $\begin{array}{r}42.3 \\
25.2 \\
5.2 \\
6.2 \\
5.7\end{array}$ & $\begin{array}{r}42.7 \\
25.5 \\
5.1 \\
5.6 \\
6.4\end{array}$ & $\begin{array}{r}42.4 \\
26.0 \\
5.1 \\
5.3 \\
6.0\end{array}$ \\
\hline Indirect texer & 26.8 & 28.6 & 32.8 & 34.7 & 36.8 & 39.0 & 45.7 & 1.9 & 2.0 & 2.2 & 2.3 & 2.3 & 2.4 & 2.6 \\
\hline
\end{tabular}

Sources: Ministry of Planning and Cooperation: and atafl extimates.

y Including Iranextions with the formet Soviet Union.

3/ Expors were medefined to inchude expons of gold by the Central Bank, previously rocorded a "monetized gold" in the capital account. The extemal current account deficit and gross savings were revised accordingly

I' Includes small - scale mining activities. 
Table 3. Guinea: Savings and Investment Balances, 1988-94

\begin{tabular}{|c|c|c|c|c|c|c|c|}
\hline & 1988 & 1989 & 1990 & 1991 & 1992 & 1993 & $\frac{1994}{\text { Est }}$ \\
\hline \multicolumn{8}{|l|}{ Government } \\
\hline $\begin{array}{l}\text { National savings } \underline{1} / \\
\text { lnvestment }\end{array}$ & $\begin{array}{r}-2.1 \\
8.2\end{array}$ & $\begin{array}{r}-0.7 \\
8.3\end{array}$ & $\begin{array}{l}0.4 \\
9.2\end{array}$ & $\begin{array}{r}-0.4 \\
7.8\end{array}$ & $\begin{array}{r}-0.5 \\
7.5\end{array}$ & $\begin{array}{r}-0.4 \\
7.1\end{array}$ & $\begin{array}{r}-1.1 \\
6.1\end{array}$ \\
\hline Net financial balance & -10.3 & -9.1 & -8.8 & -8.2 & -8.0 & -7.5 & -7.2 \\
\hline \multicolumn{8}{|l|}{ Private sector $2 /$} \\
\hline $\begin{array}{l}\text { Gross savings ]/ } \\
\text { Investment }\end{array}$ & $\begin{array}{l}6.5 \\
8.9\end{array}$ & $\begin{array}{l}9.0 \\
8.9\end{array}$ & $\begin{array}{l}8.0 \\
8.3\end{array}$ & $\begin{array}{l}8.6 \\
8.6\end{array}$ & $\begin{array}{l}4.7 \\
9.0\end{array}$ & $\begin{array}{l}5.9 \\
9.1\end{array}$ & $\begin{array}{l}5.4 \\
7.5\end{array}$ \\
\hline Net financial balance & -2.4 & 0.2 & -0.4 & -0.1 & -4.3 & -3.2 & -2.1 \\
\hline \multicolumn{8}{|l|}{ Mining companies } \\
\hline $\begin{array}{l}\text { Gross savings } \\
\text { Investment }\end{array}$ & $\begin{array}{r}10.7 \\
1.9\end{array}$ & $\begin{array}{r}13.1 \\
1.1\end{array}$ & $\begin{array}{r}11.9 \\
1.7\end{array}$ & $\begin{array}{r}11.3 \\
2.7\end{array}$ & $\begin{array}{l}8.4 \\
3.4\end{array}$ & $\begin{array}{l}7.6 \\
3.3\end{array}$ & $\begin{array}{l}5.5 \\
1.5\end{array}$ \\
\hline Net financial balance & 8.8 & 12.0 & 10.1 & 8.6 & 5.1 & 4.3 & 3.9 \\
\hline \multicolumn{8}{|l|}{ Rest of private sector 2/ } \\
\hline $\begin{array}{l}\text { Gross savings } \\
\text { Investment }\end{array}$ & $\begin{array}{r}-4.2 \\
7.0\end{array}$ & $\begin{array}{r}-4.1 \\
7.7\end{array}$ & $\begin{array}{r}-3.9 \\
6.6\end{array}$ & $\begin{array}{r}-2.8 \\
5.9\end{array}$ & $\begin{array}{r}-3.8 \\
5.6\end{array}$ & $\begin{array}{r}-1.7 \\
5.8\end{array}$ & $\begin{array}{r}-0.0 \\
6.0\end{array}$ \\
\hline Net financial balance & -112 & -11.8 & -10.5 & -8.6 & -9.4 & -7.5 & -6.0 \\
\hline \multicolumn{8}{|l|}{ Total economy } \\
\hline $\begin{array}{l}\text { Gross savings y } \\
\text { Investment }\end{array}$ & $\begin{array}{r}4.4 \\
17.1\end{array}$ & $\begin{array}{r}8.3 \\
17.2\end{array}$ & $\begin{array}{r}8.4 \\
17.5\end{array}$ & $\begin{array}{r}8.2 \\
16.5\end{array}$ & $\begin{array}{r}4.2 \\
16.5\end{array}$ & $\begin{array}{r}5.5 \\
16.2\end{array}$ & $\begin{array}{r}4.4 \\
13.6\end{array}$ \\
\hline $\begin{array}{l}\text { Net financial balance } \\
\text { (external current account balance) } y\end{array}$ & -12.7 & -8.9 & -9.1 & -8.3 & -12.3 & -10.7 & -9.3 \\
\hline \multicolumn{8}{|l|}{ Memorandum items: } \\
\hline Real GDP & 6.3 & 4.0 & 4.3 & 2.4 & 3.0 & 4.7 & 4.0 \\
\hline $\begin{array}{l}\text { Agriculture } \\
\text { lndustry } \\
\text { Of which: } \\
\text { Mining } \\
\text { Maoufacturing } \\
\text { Services } \\
\text { Of which: trade }\end{array}$ & $\begin{array}{l}3.7 \\
3.3 \\
\\
(2.0) \\
(\ldots) \\
10.0 \\
(\ldots)\end{array}$ & $\begin{array}{c}5.3 \\
3.7 \\
\\
(2.8) \\
(4.3) \\
4.5 \\
(5.1)\end{array}$ & $\begin{array}{c}3.4 \\
2.9 \\
\\
(0.2) \\
(5.0) \\
5.5 \\
(5.7)\end{array}$ & $\begin{array}{r}3.5 \\
1.0 \\
(-0.6) \\
(4.0) \\
2.7 \\
(4.0)\end{array}$ & $\begin{array}{r}3.8 \\
0.6 \\
(-1.5) \\
(2.8) \\
4.1 \\
(4.6)\end{array}$ & $\begin{array}{c}5.0 \\
3.1 \\
\\
(2.0) \\
(5.0) \\
5.7 \\
(6.0)\end{array}$ & $\begin{array}{c}5.0 \\
3.2 \\
\\
(2.0) \\
(5.5) \\
3.3 \\
(6.0)\end{array}$ \\
\hline Real per capita GDP & 3.3 & 1.0 & 1.4 & -0.5 & -- & 1.7 & 1.1 \\
\hline $\begin{array}{l}\text { ICOR (level) 3/ } \\
\text { Overall oconomy } \\
\text { Nonmining soctor }\end{array}$ & $\begin{array}{l}2.6 \\
2.3\end{array}$ & $\begin{array}{l}4.4 \\
3.9\end{array}$ & $\begin{array}{l}4.0 \\
3.7\end{array}$ & $\begin{array}{l}7.4 \\
6.7\end{array}$ & $\begin{array}{l}5.8 \\
4.8\end{array}$ & $\begin{array}{l}3.5 \\
2.8\end{array}$ & $\begin{array}{l}4.2 \\
3.4\end{array}$ \\
\hline
\end{tabular}

Sources: Dat provided by the Guinean autborities; and suff eatimates and projactions.

1/ Gross national eaving excluding foreign grants.

2' Including public enterprises.

3/. Incremental capital-ouput ratio. 
Table 4. Guinea: Consumer Price Index, 1988-95

(Period aver age dala)

\begin{tabular}{|c|c|c|c|c|c|c|c|c|c|c|c|c|c|}
\hline 1988 & \multirow{2}{*}{1989} & \multirow{2}{*}{1990} & \multirow{2}{*}{1991} & \multirow[t]{2}{*}{1992} & \multirow[t]{2}{*}{1993} & \multirow[t]{2}{*}{1994} & \multicolumn{4}{|c|}{1994} & \multicolumn{3}{|c|}{1995} \\
\hline & & & & & & & $\overline{\mathbf{Q 1}}$ & $\mathbf{Q 2}$ & $\mathbf{Q 3}$ & $\overline{Q 4}$ & $\overline{\mathbf{Q 1}}$ & $Q 2$ & $\overline{\mathbf{Q 3}}$ \\
\hline
\end{tabular}

(Index, 1987 =100)

\begin{tabular}{|c|c|c|c|c|c|c|c|c|c|c|c|c|c|c|}
\hline Aggregate index & 127.4 & $\underline{163.5}$ & $\underline{195.1}$ & $\underline{2335}$ & $\underline{272.2}$ & $\underline{291.6}$ & $\underline{303.5}$ & 296.1 & $\underline{2981}$ & 310.7 & 309.3 & 3125 & $\underline{315.4}$ & $\underline{327.4}$ \\
\hline Food & 133.6 & 168.6 & 198.8 & 231.1 & 267.9 & 2929 & 306.7 & 297.9 & 296.9 & 317.4 & 314.8 & 3181 & 322.0 & 346.7 \\
\hline Nonfood & 1224 & 159.2 & 1921 & 235.4 & 275.7 & 290.6 & 300.9 & 294.6 & 299.1 & 305.3 & 304.8 & 307.9 & 310.1 & 311.7 \\
\hline $\begin{array}{l}\text { Cothing } \\
\text { Health } \\
\text { Housing }\end{array}$ & $\begin{array}{l}121.7 \\
120.0 \\
108.2\end{array}$ & $\begin{array}{l}129.2 \\
148.4 \\
145.1\end{array}$ & $\begin{array}{l}150.8 \\
195.8 \\
1735\end{array}$ & $\begin{array}{l}168.0 \\
235.9 \\
195.8\end{array}$ & $\begin{array}{l}179.1 \\
258.6 \\
235.8\end{array}$ & $\begin{array}{l}196.9 \\
267.1 \\
247.6\end{array}$ & $\begin{array}{l}200.0 \\
304.6 \\
249.0\end{array}$ & $\begin{array}{l}199.4 \\
284.7 \\
248.5\end{array}$ & $\begin{array}{l}200.6 \\
297.9 \\
249.0\end{array}$ & \begin{tabular}{l|}
200.6 \\
310.8 \\
249.2
\end{tabular} & $\begin{array}{l}199.4 \\
325.1 \\
249.5\end{array}$ & $\begin{array}{l}200.4 \\
334.8 \\
249.5\end{array}$ & $\begin{array}{l}195.8 \\
333.5 \\
251.9\end{array}$ & $\begin{array}{l}195.8 \\
336.4 \\
257.5\end{array}$ \\
\hline $\begin{array}{l}\text { Electricity } \\
\text { and waler } \\
\text { Transportation } \\
\text { Leisure and culture }\end{array}$ & $\begin{array}{l}117.7 \\
140.2 \\
115.1\end{array}$ & $\begin{array}{l}135.3 \\
187.0 \\
163.3\end{array}$ & $\begin{array}{l}160.9 \\
222.9 \\
190.0\end{array}$ & $\begin{array}{l}207.6 \\
310.8 \\
217.8\end{array}$ & $\begin{array}{l}233.1 \\
393.4 \\
255.1\end{array}$ & $\begin{array}{l}233.5 \\
424.1 \\
272.6\end{array}$ & $\begin{array}{l}239.2 \\
427.2 \\
285.7\end{array}$ & $\begin{array}{l}232.5 \\
422.0 \\
278.6\end{array}$ & $\begin{array}{l}236.2 \\
422.2 \\
286.0\end{array}$ & $\begin{array}{l}241.5 \\
446.1 \\
283.9\end{array}$ & $\begin{array}{l}246.7 \\
418.4 \\
294.3\end{array}$ & $\begin{array}{l}247.2 \\
419.2 \\
313.0\end{array}$ & $\begin{array}{l}247.0 \\
420.6 \\
337.8\end{array}$ & $\begin{array}{l}246.9 \\
422.6 \\
332.7\end{array}$ \\
\hline
\end{tabular}

(Annual percentage changes)

\begin{tabular}{|c|c|c|c|c|c|c|c|c|c|c|c|c|c|c|}
\hline Aggregate index & $\underline{27.4}$ & $\underline{28.3}$ & $\underline{19.4}$ & $\underline{19.6}$ & $\underline{16.6}$ & $\underline{7.1}$ & 4.1 & $\underline{2.7}$ & $\underline{2.8}$ & $\underline{6.0}$ & 4.9 & $\underline{5.5}$ & $\underline{5.8}$ & $\underline{5.4}$ \\
\hline Food & 33.6 & 26.2 & 17.9 & 16.2 & 15.9 & 9.3 & 4.7 & 3.6 & 2.1 & 7.2 & 6.1 & 6.8 & 8.4 & 9.2 \\
\hline Nonfood & 22.4 & 30.1 & 20.6 & 22.5 & 17.1 & 5.4 & 3.6 & 2.0 & 3.3 & 5.0 & 3.9 & 4.5 & 3.7 & 2.1 \\
\hline Cothing & 21.7 & 6.1 & 16.8 & 11.4 & 6.6 & 9.9 & 1.6 & 3.5 & 1.3 & 1.0 & 0.6 & 0.5 & -2.4 & -2.4 \\
\hline Health & 20.0 & 23.7 & 32.0 & 20.5 & 9.6 & 3.3 & 14.1 & 8.9 & 13.7 & 16.8 & 16.5 & 17.6 & 12.0 & 8.2 \\
\hline Housing & 8.2 & 34.1 & 19.6 & 12.9 & 20.4 & 5.0 & 0.6 & 2.4 & 0.6 & -0.5 & -0.2 & 0.4 & 1.2 & 3.3 \\
\hline \multicolumn{15}{|l|}{ Electricity } \\
\hline and water & 17.7 & 14.9 & 18.9 & 29.0 & 12.3 & 0.2 & 2.5 & -2.3 & 2.2 & 3.9 & 6.2 & 6.3 & 4.6 & 2.2 \\
\hline Transportation & 40.2 & 33.4 & 19.2 & 39.4 & 26.6 & 7.8 & 0.7 & -2.2 & 0.3 & 5.7 & -0.8 & -0.7 & -0.4 & -5.3 \\
\hline Leisure and culture & 15.1 & 41.9 & 16.4 & 14.6 & 17.1 & 6.9 & 4.8 & 4.2 & 4.4 & 3.2 & 7.4 & 12.3 & 18.1 & 17.2 \\
\hline
\end{tabular}

Sources: Data provided by the Guinean authorities and staff estimates. 
(End-period data)

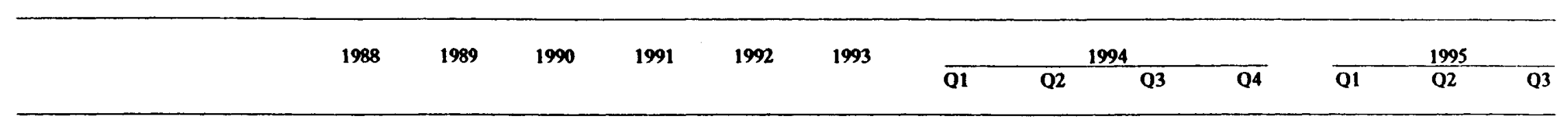

\begin{tabular}{|c|c|c|c|c|c|c|c|c|c|c|c|c|c|c|}
\hline \multirow[b]{2}{*}{ Aggregate index } & \multicolumn{14}{|c|}{ (Index, $1987=100)$} \\
\hline & $\underline{137.0}$ & $\underline{172.7}$ & $\underline{219.4}$ & $\underline{246.1}$ & $\underline{285.7}$ & $\underline{300.0}$ & $\underline{294.1}$ & $\underline{301.2}$ & $\underline{319.0}$ & $\underline{306.6}$ & $\underline{311.8}$ & $\underline{319.0}$ & $\underline{330.8}$ & \\
\hline Food & 144.8 & 170.8 & 219.1 & 238.0 & 285.8 & 308.4 & 293.4 & 303.2 & 337.7 & 307.9 & 317.5 & 329.4 & 352.9 & \\
\hline Nonfood & 130.6 & 174.2 & 219.6 & 252.8 & 285.7 & 293.1 & 294.6 & 299.6 & 303.6 & 305.6 & 307.2 & 310.4 & 312.6 & \\
\hline $\begin{array}{l}\text { Clothing } \\
\text { Health } \\
\text { Housing } \\
\text { Electricity }\end{array}$ & $\begin{array}{l}121.6 \\
134.2 \\
111.8\end{array}$ & $\begin{array}{l}143.6 \\
168.2 \\
163.6\end{array}$ & $\begin{array}{l}163.4 \\
227.4 \\
183.1\end{array}$ & $\begin{array}{l}176.4 \\
242.4 \\
217.4\end{array}$ & $\begin{array}{l}193.9 \\
259.9 \\
240.6\end{array}$ & $\begin{array}{l}198.6 \\
280.0 \\
249.3\end{array}$ & $\begin{array}{l}200.6 \\
282.0 \\
248.4\end{array}$ & $\begin{array}{l}199.9 \\
306.0 \\
248.4\end{array}$ & $\begin{array}{l}199.4 \\
314.2 \\
249.8\end{array}$ & $\begin{array}{l}200.9 \\
326.3 \\
249.8\end{array}$ & $\begin{array}{l}196.5 \\
336.3 \\
248.2\end{array}$ & $\begin{array}{l}194.6 \\
335.5 \\
253.7\end{array}$ & $\begin{array}{l}196.0 \\
338.9 \\
258.4\end{array}$ & \\
\hline $\begin{array}{l}\text { and wate } \\
\text { Transportation } \\
\text { Leisure and culture }\end{array}$ & $\begin{array}{l}119.1 \\
145.9 \\
126.5\end{array}$ & $\begin{array}{l}133.1 \\
195.9 \\
177.7\end{array}$ & $\begin{array}{l}195.5 \\
274.8 \\
206.7\end{array}$ & $\begin{array}{l}221.0 \\
328.3 \\
237.2\end{array}$ & $\begin{array}{l}234.7 \\
419.6 \\
265.7\end{array}$ & $\begin{array}{l}233.0 \\
421.9 \\
275.1\end{array}$ & $\begin{array}{l}232.5 \\
422.2 \\
279.6\end{array}$ & $\begin{array}{l}237.4 \\
422.2 \\
283.2\end{array}$ & $\begin{array}{l}243.6 \\
436.4 \\
285.3\end{array}$ & $\begin{array}{l}247.8 \\
418.0 \\
299.3\end{array}$ & $\begin{array}{l}246.9 \\
419.6 \\
312.9\end{array}$ & $\begin{array}{l}247.1 \\
422.6 \\
330.9\end{array}$ & $\begin{array}{l}246.7 \\
422.6 \\
334.0\end{array}$ & $\begin{array}{l}1 \\
\omega\end{array}$ \\
\hline
\end{tabular}

\begin{tabular}{|c|c|c|c|c|c|c|c|c|c|c|c|c|c|}
\hline Aggregate index & $\underline{26.3}$ & $\underline{26.0}$ & $\underline{27.1}$ & $\underline{12.2}$ & $\underline{16.1}$ & $\underline{5.0}$ & $\underline{1.2}$ & $\underline{3.6}$ & $\underline{8.9}$ & $\underline{2.2}$ & $\underline{6.0}$ & 5.9 & $\underline{3.7}$ \\
\hline Food & 30.3 & 17.9 & 28.3 & 8.6 & 20.1 & 7.9 & 1.1 & 3.7 & 14.9 & -0.2 & 8.2 & 8.6 & 4.5 \\
\hline Nonfood & 22.9 & 33.3 & 26.0 & 15.1 & 13.0 & 2.6 & 1.3 & 3.5 & 4.0 & 4.3 & 4.3 & 3.6 & 3.0 \\
\hline $\begin{array}{l}\text { Clothing } \\
\text { Health }\end{array}$ & $\begin{array}{r}5.4 \\
24.2 \\
4.4\end{array}$ & $\begin{array}{l}18.1 \\
25.3 \\
46.4\end{array}$ & $\begin{array}{l}13.8 \\
35.2 \\
11.9\end{array}$ & $\begin{array}{r}8.0 \\
6.6 \\
18.7\end{array}$ & $\begin{array}{r}9.9 \\
7.2 \\
10.7\end{array}$ & $\begin{array}{l}2.5 \\
7.7 \\
3.6\end{array}$ & $\begin{array}{l}2.6 \\
7.3 \\
1.3\end{array}$ & $\begin{array}{r}0.4 \\
17.2 \\
-0.4\end{array}$ & $\begin{array}{r}0.3 \\
15.8 \\
-0.2\end{array}$ & $\begin{array}{r}1.2 \\
16.5 \\
0.2\end{array}$ & $\begin{array}{r}-2.0 \\
19.3 \\
-0.1\end{array}$ & $\begin{array}{r}-2.6 \\
9.7 \\
2.1\end{array}$ & $\begin{array}{r}-1.7 \\
7.9 \\
3.5\end{array}$ \\
\hline $\begin{array}{l}\text { Housing } \\
\text { Electricity }\end{array}$ & 4.4 & 46.4 & 11.9 & 18.7 & 10.7 & 3.6 & 1.3 & -0.4 & & & -0.1 & 2.1 & 3.0 \\
\hline $\begin{array}{l}\text { and wate } \\
\text { Transportation }\end{array}$ & $\begin{array}{l}12.9 \\
37.7 \\
20.7\end{array}$ & $\begin{array}{l}11.7 \\
34.3 \\
40.5\end{array}$ & $\begin{array}{l}46.9 \\
40.3 \\
16.3\end{array}$ & $\begin{array}{l}13.0 \\
19.5 \\
14.7\end{array}$ & $\begin{array}{r}6.2 \\
27.8 \\
12.0\end{array}$ & $\begin{array}{r}-0.8 \\
0.5 \\
3.6\end{array}$ & $\begin{array}{r}-1.6 \\
-3.3 \\
4.2\end{array}$ & $\begin{array}{l}3.1 \\
0.0 \\
4.7\end{array}$ & $\begin{array}{l}4.9 \\
3.4 \\
4.1\end{array}$ & $\begin{array}{r}6.4 \\
-0.9 \\
8.8\end{array}$ & $\begin{array}{r}6.2 \\
-0.6 \\
11.9\end{array}$ & $\begin{array}{r}4.1 \\
0.1 \\
16.8\end{array}$ & $\begin{array}{r}1.3 \\
-3.2 \\
17.0\end{array}$ \\
\hline
\end{tabular}

Sources: Data provided by the Guinean authorities; and staff estimates. 
Table 6. Guinea: Financial Operations of the Central Government 1988-95 11

\begin{tabular}{|c|c|c|c|c|c|c|c|c|}
\hline & 1988 & 1989 & 1990 & 1991 & 1992 & 1993 & $\frac{1994}{E_{s t .}}$ & $\frac{1995}{\begin{array}{c}\text { Revised } \\
\text { budget }\end{array}}$ \\
\hline & \multicolumn{8}{|c|}{ (In billions of Guinean francs) } \\
\hline Revenue and grants & $\underline{199.6}$ & $\underline{274.9}$ & $\underline{362.1}$ & 412.5 & 478.4 & $\underline{464.3}$ & 460.8 & $\underline{564.9}$ \\
\hline Revenue & 162.8 & 222.4 & 293.8 & 329.9 & 361.1 & 351.6 & 343.3 & 418.0 \\
\hline Mining sector revenue & 111.3 & 150.7 & 197.6 & 190.0 & 162.7 & 137.5 & 98.5 & 116.8 \\
\hline Nonmining sector revenue & 51.5 & 71.7 & 96.3 & 140.0 & 198.4 & 214.1 & 244.8 & 301.2 \\
\hline Direct taxes & 3.0 & 5.0 & 6.3 & 13.9 & 24.6 & 24.3 & 30.1 & 40.6 \\
\hline Other domestic taxes & 23.4 & $\mathbf{3 8 . 0}$ & 41.7 & 68.4 & 101.3 & 114.5 & 136.5 & 171.1 \\
\hline International trade & 11.1 & 14.2 & 25.7 & 38.2 & 46.3 & 51.2 & 53.8 & 61.5 \\
\hline Nontax revenue & 14.0 & 14.5 & 22.6 & 19.5 & 26.2 & 24.0 & 24.4 & 28.0 \\
\hline Grants & 36.8 & 52.5 & 68.3 & 62.5 & 117.3 & 112.7 & 117.5 & 146.9 \\
\hline Expenditure and net lending & $\underline{276.3}$ & $\underline{347.5}$ & $\underline{458.5}$ & $\underline{\mathbf{s 1 5 . 2}}$ & $\underline{571.5}$ & $\underline{579.6}$ & $\underline{580.5}$ & 637.0 \\
\hline Current expenditure & 252.9 & 187.7 & 230.0 & 280.3 & 303.0 & 293.5 & 311.7 & 323.3 \\
\hline Wages and salaries & 45.5 & 60.7 & 78.5 & 102.9 & 132.1 & 140.3 & 145.5 & 154.9 \\
\hline Other goods and services & 50.1 & 67.5 & 86.7 & 96.2 & 89.4 & 80.6 & 76.5 & 72.7 \\
\hline Subridies and transfert & 21.5 & 24.4 & 17.2 & 28.0 & 32.6 & 31.1 & 37.3 & 47.8 \\
\hline Interest due on external debt & 35.8 & 35.0 & 47.6 & 53.2 & 48.9 & 40.3 & 49.7 & 44.3 \\
\hline In:erest on domestie debt & & & & & & 1.2 & 2.7 & 3.6 \\
\hline Public investment program & 123.5 & 159.8 & 228.4 & 234.9 & 265.7 & 286.1 & 268.8 & 313.7 \\
\hline Externally financed & 102.4 & 132.3 & 187.4 & 195.0 & 234.0 & 240.5 & 230.0 & 262.7 \\
\hline Domestically financed & 21.1 & 27.5 & 41.0 & 39.9 & 31.7 & 45.6 & 38.8 & 51.0 \\
\hline Net lending & $\ldots$ & $\ldots$ & $\cdots$ & $\cdots$ & 2.8 & -- & -- & -- \\
\hline \multicolumn{9}{|l|}{ Balance, commitment basis } \\
\hline $\begin{array}{l}\text { Including grants } \\
\text { Excluding grants }\end{array}$ & $\begin{array}{r}-76.7 \\
-113.5\end{array}$ & $\begin{array}{r}-72.6 \\
-125.1\end{array}$ & $\begin{array}{r}-96.3 \\
-164.6\end{array}$ & $\begin{array}{l}-102.7 \\
-185.3\end{array}$ & $\begin{array}{r}-93.1 \\
-210.4\end{array}$ & $\begin{array}{l}-115.3 \\
-228.0\end{array}$ & $\begin{array}{l}-119.8 \\
-237.2\end{array}$ & $\begin{array}{r}-72.1 \\
-219.0\end{array}$ \\
\hline Change in payments arrears & 7.3 & -1.6 & $\underline{37.7}$ & 12.1 & -97.4 & $\underline{0.3}$ & 19.2 & -63.7 \\
\hline Domestic $2 /$ & 1.0 & 4.9 & 8.2 & -0.4 & -20.0 & $-\frac{-4.2}{4.2}$ & 7.9 & $\overline{-47.4}$ \\
\hline External & 6.4 & -6.4 & 29.5 & 12.6 & -77.4 & 4.5 & 11.3 & -16.3 \\
\hline Balance, cash basis & -69.4 & $=74.2$ & -58.6 & -90.6 & -190.5 & -115.0 & -100.6 & -135.8 \\
\hline Financing & 69.4 & $\underline{24.2}$ & $\underline{58.6}$ & $\underline{90.6}$ & 190.5 & 115.0 & 100.6 & 135.8 \\
\hline Net external financing & 58.5 & 83.7 & 75.7 & 74.5 & 199.2 & 149.7 & 86.3 & 139.7 \\
\hline Drawings & $\mathbf{9 4 . 3}$ & 124.1 & 120.0 & 147.3 & 160.7 & 194.0 & 136.0 & 161.6 \\
\hline Projed financing & 72.1 & 86.8 & 117.4 & 122.4 & 134.0 & 143.9 & 128.5 & 143.7 \\
\hline Other & 22.2 & 37.2 & 2.5 & 24.9 & 26.8 & 50.1 & 7.5 & 17.9 \\
\hline Amortization due & -68.7 & -73.7 & -82.6 & -117.3 & -115.7 & -93.6 & -139.5 & -94.3 \\
\hline Short-term debl, net & $\ldots$ & & 7.6 & -0.9 & -1.1 & -4.3 & -5.7 & -- \\
\hline Arrears (reduction -) & 21.9 & -11.4 & 30.8 & 45.4 & -219.4 & 70.9 & 95.4 & -178.2 \\
\hline Debt relief & 11.0 & 4.8 & -- & -- & 346.8 & 56.3 & $\ldots$ & 250.6 \\
\hline Deferted payments & $\ldots$ & $\ldots$ & -- & $\ldots$ & 28.0 & -73.6 & $\ldots$ & - \\
\hline Net domestic financing & 10.9 & -9.6 & -17.1 & 16.1 & -8.7 & -34.7 & 14.3 & -3.9 \\
\hline Banking system & 12.3 & -8.0 & -16.2 & 16.8 & 12.0 & -7.6 & 21.4 & -5.4 \\
\hline Nonbank financing & -1.4 & -1.5 & -0.9 & -0.8 & -20.2 & -15.6 & 5.8 & 12.6 \\
\hline Of which: privatization proceeds & $(--)$ & $(--)$ & $(--)$ & $(--)$ & (0.9) & (1.0) & (0.7) & (2.5) \\
\hline Amortization of do mestic debt & -- & -- & -- & -- & -0.5 & -11.5 & -12.9 & -11.0 \\
\hline Of which: debl conversion & $(--)$ & $(--)$ & $(--)$ & $(--)$ & $(-0.5)$ & $(-3.6)$ & $(-3.8)$ & $(-5.6)$ \\
\hline Memorandum items: & \multicolumn{8}{|c|}{ (In percent of GDP) } \\
\hline Revenue and grants & 17.6 & 19.1 & 19.5 & 18.3 & 17.8 & 15.3 & 13.9 & 15.5 \\
\hline Expenditure & 24.4 & 24.2 & 24.6 & 22.9 & 21.3 & 19.1 & 17.5 & 17.5 \\
\hline \multicolumn{9}{|l|}{ Balance, commitment basis } \\
\hline Including grants & -6.8 & -5.0 & -5.2 & -4.6 & -3.5 & -3.8 & -3.6 & -2.0 \\
\hline Excluding grants & -10.0 & -8.7 & -8.8 & -8.2 & -7.8 & -7.5 & -7.2 & -6.0 \\
\hline Balance, cash basis & -6.1 & -5.2 & -3.2 & -4.0 & -7.1 & -3.8 & -3.0 & -3.7 \\
\hline \multicolumn{9}{|l|}{ Primary balance $3 /$} \\
\hline Including mining revenue & 2.2 & 2.9 & 3.8 & 2.8 & 2.7 & 1.8 & 1.4 & 2.5 \\
\hline Excluding mining revenue & -7.7 & -7.5 & -6.8 & -5.6 & -3.4 & -2.8 & -1.6 & -0.7 \\
\hline
\end{tabular}

Sources: Ministry of Finance: and stafl eatimates.

1/ Including transactions with the former Soviet Union.

$2 /$ Comprises the change in outstanding domestic artears and the change in the float between expenditure commitments and cash payments for the current fiseal year.

3/ Domestic revenue minus noninterest current spending and domestically finaneed investment. 
Table 7. Guinea: Central Government Revenue, 1988-94

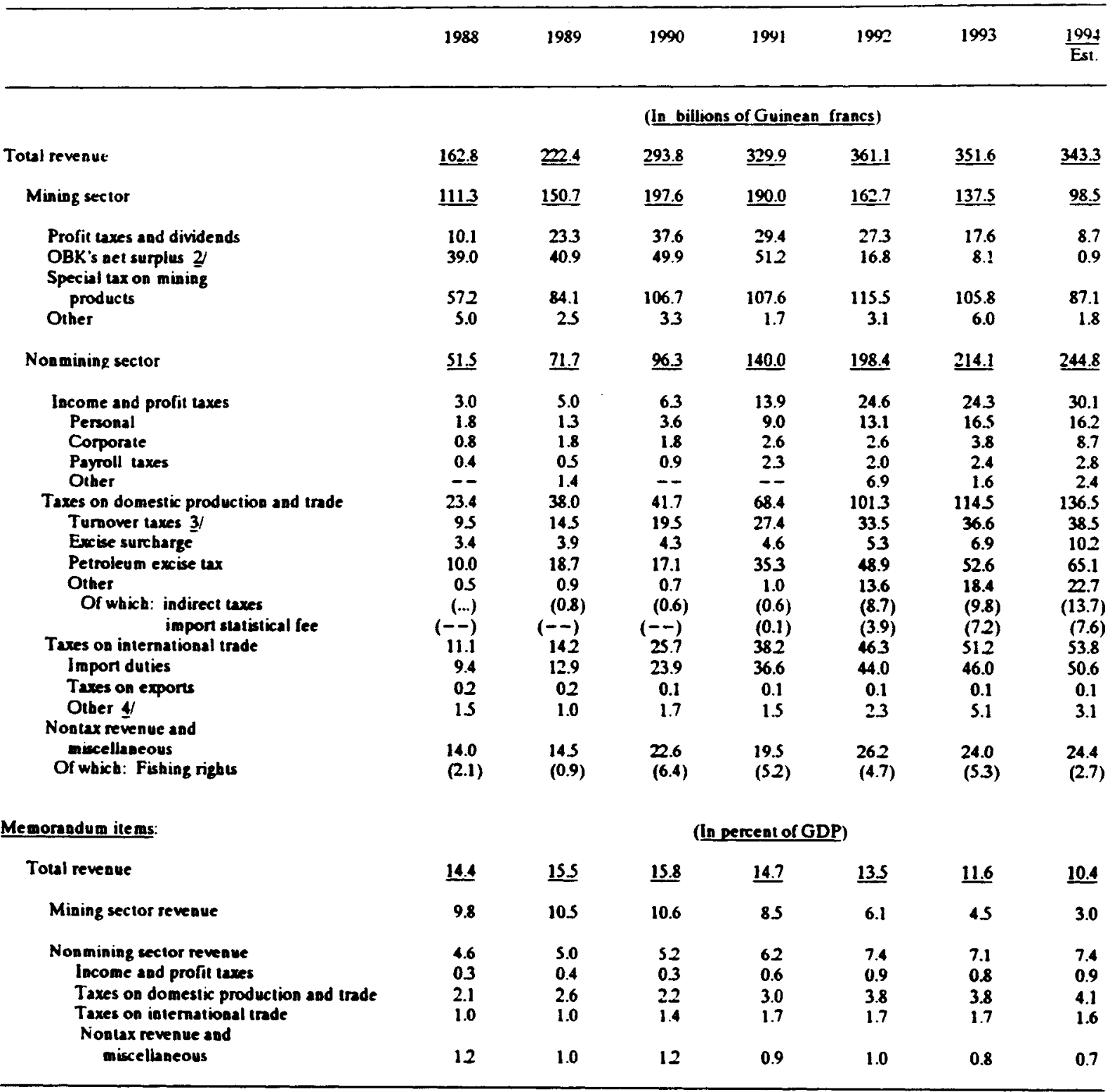

Sources: Ministry of Finance; and staff estimates.

1/ locludiag transactions with the former Soviet Union.

2) Net surplus of the Kindi Bauxite Orrice until 1992, and turnover taxes on the Kindi Bauxte Conpany siace 1993.

3/ Includiag lumover taxes on imports.

4 Including recovery of arrears. 
Table 8. Guinea: Central Government Expenditure, 1988-94 y/

\begin{tabular}{|c|c|c|c|c|c|c|c|}
\hline & 1988 & 1989 & 1990 & 1991 & 1992 & 1993 & $\frac{1994}{\text { Est. }}$ \\
\hline & \multicolumn{7}{|c|}{ (In billions of Guinean franes) } \\
\hline Total expenditure & $\underline{276.3}$ & $\underline{347.5}$ & $\underline{458.5}$ & $\underline{515.2}$ & $\underline{568.3}$ & $\underline{\mathbf{5 7 0 . 0}}$ & $\underline{580.5}$ \\
\hline Current expenditure & $\underline{152.9}$ & $\underline{187.6}$ & $\underline{230.0}$ & $\underline{280.3}$ & $\underline{302.7}$ & $\underline{293.4}$ & $\underline{311.7}$ \\
\hline Wages and salaries & 45.5 & 60.7 & 78.5 & 102.9 & 132.1 & 140.3 & 145.5 \\
\hline Base salaries & 44.6 & 57.2 & 74.7 & 98.8 & 127.6 & 134.2 & 139.2 \\
\hline Other renumeration & 0.9 & 3.5 & 3.8 & 4.1 & 4.5 & 6.1 & 6.3 \\
\hline Other goods and services $\underline{y}$ & 50.1 & 67.5 & 86.7 & 96.2 & 89.4 & 80.6 & 76.5 \\
\hline OBK-financed expenditure & 12.8 & 11.7 & 20.0 & 24.4 & 12.1 & 1.0 & - \\
\hline Other & 37.3 & 55.8 & 66.7 & 71.8 & 77.3 & 79.6 & 76.5 \\
\hline Subsidies and transfers & 21.5 & 24.4 & 17.2 & 28.0 & 32.6 & 31.1 & 37.3 \\
\hline $\begin{array}{l}\text { Public entities } \\
\text { Subsidies to enterprises }\end{array}$ & 2.2 & 2.1 & 3.0 & 4.6 & 0.8 & 0.9 & 0.6 \\
\hline and guarantees & 11.3 & 4.4 & 3.9 & 7.2 & 5.0 & 3.6 & 3.8 \\
\hline Social and cultural funds $2 /$ & 0.6 & 1.7 & 2.3 & 2.8 & 3.2 & 3.9 & 9.7 \\
\hline Other transfers & 7.4 & 16.2 & $\mathbf{8 . 0}$ & 13.4 & 23.6 & 22.7 & 23.2 \\
\hline Interest payments & 35.8 & 35.0 & 47.6 & 53.2 & 48.6 & 41.5 & 52.4 \\
\hline Of which: external debt & (35.8) & (35.0) & (47.6) & (53.2) & (48.9) & (40.3) & (49.7) \\
\hline Public investment program & $\underline{123.5}$ & $\underline{159.8}$ & $\underline{228.4}$ & $\underline{234.9}$ & $\underline{265.7}$ & $\underline{286.1}$ & $\underline{268.8}$ \\
\hline Domestically financed & 21.1 & 27.5 & 41.0 & 39.9 & 31.7 & 45.6 & 38.8 \\
\hline Foreign financed & 102.4 & 132.3 & 187.4 & 195.0 & 234.0 & 240.5 & 230.0 \\
\hline Loans & 72.1 & 86.8 & 117.4 & 122.4 & 134.0 & 143.9 & 128.5 \\
\hline Grants & 30.3 & 45.5 & 70.0 & 72.6 & 100.0 & 96.6 & 101.5 \\
\hline Net lending & ... & ... & ... & ... & 2.8 & -- & -- \\
\hline \multicolumn{8}{|l|}{ Memorandum items: } \\
\hline \multirow[t]{2}{*}{ Defense expenditure } & .. & ... & ... & 54.1 & 50.2 & 42.0 & 44.8 \\
\hline & \multicolumn{7}{|c|}{ (In percent of GDP) } \\
\hline Total expenditure & $\underline{24.4}$ & $\underline{24.2}$ & $\underline{24.6}$ & $\underline{22.9}$ & $\underline{21.2}$ & $\underline{18.8}$ & $\underline{17.5}$ \\
\hline Current expenditure & 13.5 & 13.0 & 12.4 & 12.5 & 11.3 & 9.7 & 9.4 \\
\hline Wages and salaries & 4.0 & 4.2 & 4.2 & 4.6 & 4.9 & 4.6 & 4.4 \\
\hline Other goods and services 2 & 4.4 & 4.7 & 4.7 & 4.3 & 3.3 & 2.7 & 2.3 \\
\hline Subsidies and iransfers 2 & 1.9 & 1.7 & 0.9 & 1.2 & 1.2 & 1.0 & 1.1 \\
\hline Interest payments & 3.2 & 2.4 & 2.6 & 2.4 & 1.8 & 1.4 & 1.6 \\
\hline Capital expenditure & 10.9 & 11.1 & 12.3 & 10.4 & 9.9 & 9.4 & 8.1 \\
\hline Domestically financed & 1.9 & 1.9 & 2.2 & 1.8 & 1.2 & 1.5 & 1.2 \\
\hline Foreign financed & 9.1 & 9.2 & 10.1 & 8.7 & 8.7 & 7.9 & 6.9 \\
\hline Net lending & -- & -- & -- & -- & 0.1 & -- & -- \\
\hline
\end{tabular}

Sources: Ministry of Finance; and staff estimates.

1/ Including transactions with the former Soviet Union.

21 With effect from 1994, certain outlays relating to hospitals and uniersities were reclassified from "other goods and services" to "subsidies and transfers". 
Table 9. Guinea: Monetary Survey, 1990-95 $1 /$

\begin{tabular}{|c|c|c|c|c|c|c|c|c|c|c|c|}
\hline & \multirow[t]{2}{*}{1990} & \multirow[t]{2}{*}{1991} & \multirow[t]{2}{*}{1992} & \multirow[t]{2}{*}{1993} & \multicolumn{4}{|c|}{1994} & \multicolumn{3}{|c|}{1995} \\
\hline & & & & & $\overline{\text { Mar. }}$ & June & Sep. & Dee. & $\overline{\text { Mar. }}$ & June & $\overline{\text { Sep. }}$ \\
\hline & \multicolumn{11}{|c|}{ (In billion of Guinean francs; end of period) } \\
\hline Net foreign assets & 58.9 & 81.1 & 112.5 & 161.3 & 129.4 & 129.4 & 106.8 & 121.4 & 122.7 & 127.1 & 134.7 \\
\hline Central bank & 4.3 & 57.0 & 74.2 & 123.7 & 94.0 & 98.0 & 83.6 & 88.1 & 89.6 & 112.3 & 115.0 \\
\hline Deposit money benks & 14.7 & 24.1 & 38.3 & 37.6 & 35.3 & 31.5 & 23.2 & 33.2 & $\mathbf{3 3 . 0}$ & 14.8 & 19.7 \\
\hline Net domestic assets & 95.1 & 126.6 & 143.9 & 153.8 & 161.4 & 156.1 & 171.4 & 183.2 & 188.6 & 209.5 & 208.4 \\
\hline Domestic credit & 95.1 & 122.4 & 158.1 & 161.4 & 168.6 & 163.9 & 202.7 & 212.3 & 234.2 & 244.3 & 264.5 \\
\hline Public seetor & 23.5 & 42.4 & 53.6 & 45.9 & 45.1 & 37.7 & 56.2 & 67.9 & 68.2 & 71.8 & 87.9 \\
\hline Government (net) & 23.1 & 39.9 & 51.1 & 43.4 & 42.0 & 35.5 & 53.8 & 64.8 & 65.2 & 68.5 & 84.8 \\
\hline State enterprises (grost) & 0.4 & 2.5 & 2.4 & 2.5 & 3.2 & 2.3 & 2.4 & 3.1 & 3.0 & 3.3 & 3.1 \\
\hline Private sector $2 /$ & 71.6 & 80.0 & 104.5 & 115.5 & 123.5 & 126.2 & 146.5 & 144.4 & 166.0 & 172.4 & 176.6 \\
\hline Healthy credit & 63.0 & 62.0 & 83.6 & 106.3 & 114.4 & 112.6 & 124.2 & 119.4 & 128.2 & 130.9 & 137.1 \\
\hline Nonperforming & 8.6 & 18.0 & 20.9 & 9.2 & 9.1 & 13.6 & 22.3 & 25.0 & 37.8 & 41.6 & 39.5 \\
\hline Other items (net) & -0.0 & 4.2 & -14.2 & -7.6 & -7.2 & -7.9 & -31.3 & -29.1 & -45.7 & -34.8 & -56.1 \\
\hline Central Bank & 14.0 & 18.4 & 12.6 & 15.5 & 14.3 & 13.2 & 4.4 & 7.9 & 11.1 & 10.7 & 4.3 \\
\hline Deposit money banks & -10.2 & -9.0 & -20.2 & -19.8 & -19.7 & -20.9 & -30.3 & -32.0 & -47.7 & -48.2 & -55.3 \\
\hline Other (net) & -3.8 & -5.2 & -6.5 & -3.3 & -1.8 & -0.2 & -5.4 & -5.0 & -9.1 & 2.7 & -5.0 \\
\hline Broad money & 154.0 & 207.7 & 256.4 & 315.1 & 290.8 & 285.5 & 278.1 & 304.5 & 311.2 & 336.6 & 343.1 \\
\hline Money and quasi - woney & 144.4 & 194.2 & 238.7 & 283.5 & 261.6 & 261.9 & 255.6 & 276.1 & 280.5 & 308.4 & 307.0 \\
\hline Currency & 8.7 & 119.4 & 133.0 & 166.6 & 150.5 & 147.7 & 138.1 & 154.8 & 153.0 & 164.2 & 157.5 \\
\hline Demand depocits & 42.3 & 66.1 & 84.7 & 93.7 & 85.8 & 86.8 & 87.4 & 97.6 & 98.2 & 108.5 & 115.4 \\
\hline Term deposins & 17.4 & 8.7 & 21.0 & 23.2 & 25.3 & 27.5 & 30.1 & 23.7 & 29.3 & 35.7 & 34.1 \\
\hline Foreign currency deposits & 9.7 & 13.5 & 17.6 & 31.6 & 29.1 & 23.6 & 22.5 & 28.5 & 30.7 & 28.2 & 36.1 \\
\hline Memotandum items: & \multicolumn{11}{|c|}{ (Annual percentase changes, unleas otherwise indicated) } \\
\hline Net foreign assets & & & & & & & & & & & \\
\hline In percent of broad money & 37.6 & 14.4 & 15.1 & 19.0 & 5.0 & -2.8 & -21.0 & -12.7 & -2.3 & -0.8 & 10.0 \\
\hline Net domeatic ausets & & & & & & & & & & & \\
\hline In percent of broad money & -10.4 & 20.5 & 8.3 & 3.9 & 2.2 & 10.3 & 14.7 & 9.3 & 9.4 & 18.7 & 13.3 \\
\hline Domestic credit & & & & & & & & & & & \\
\hline $\begin{array}{l}\text { In percent of broad money } \\
\text { Public sector }\end{array}$ & 2.1 & 17.7 & 17.2 & 1.3 & 2.3 & 9.7 & 18.7 & 16.2 & 22.6 & 28.1 & 22.2 \\
\hline In percent of broad money & -13.2 & 12.3 & 5.4 & -3.0 & -3.0 & 6.8 & 9.0 & 7.0 & 7.9 & 11.9 & 11.4 \\
\hline $\begin{array}{l}\text { Privale sector } 21 \\
\text { Of which healthy credit }\end{array}$ & $\begin{array}{l}34.8 \\
(34.0)\end{array}$ & $\begin{array}{c}11.7 \\
(-1.7)\end{array}$ & $\begin{array}{r}30.6 \\
(35.0)\end{array}$ & $\begin{array}{c}10.5 \\
(27.1)\end{array}$ & $\begin{array}{l}13.2 \\
(27.8)\end{array}$ & $\begin{array}{l}6.6 \\
(16.2)\end{array}$ & $\begin{aligned} 24.4 \\
(29.7)\end{aligned}$ & $\begin{array}{l}25.0 \\
(12.3)\end{array}$ & $\begin{array}{r}34.4 \\
(12.1)\end{array}$ & $\begin{array}{c}36.7 \\
(16.2)\end{array}$ & $\begin{array}{l}20.5 \\
(10.4)\end{array}$ \\
\hline Broad money & 27.2 & 34.8 & 23.4 & 22.9 & 7.2 & 7.5 & -6.3 & -3.3 & 7.0 & 17.9 & 23.4 \\
\hline Average stock of broad money & 24.6 & 24.2 & 28.0 & 24.6 & 20.9 & 17.4 & 11.9 & 4.9 & 2.2 & 4.3 & 7.3 \\
\hline Currengy outside banks & 22.1 & 40.9 & 11.4 & 25.2 & 5.2 & 10.5 & -8.0 & -7.1 & 1.6 & 11.2 & 14.0 \\
\hline Reserve money & 26.7 & 43.6 & 13.6 & 20.8 & 2.0 & 6.1 & -13.0 & -8.3 & 7.0 & 18.9 & 24.5 \\
\hline \multirow{4}{*}{$\begin{array}{l}\text { Velocity of circulation } 3 / \\
\text { End-period } \\
\text { Five-quarter average }\end{array}$} & & & & & & & & & & & \\
\hline & 12.1 & 10.8 & 10.5 & 9.6 & $\ldots$ & $\ldots$ & $\ldots$ & 10.9 & ... & $\ldots$ & $\ldots$ \\
\hline & 13.1 & 12.8 & 11.9 & 10.8 & $\cdots$ & $\cdots$ & $\cdots$ & 11.2 & $\ldots$ & $\ldots$ & $\ldots$ \\
\hline & \multicolumn{11}{|c|}{ (Ratios, in percens) } \\
\hline Broad money/GDP 3 / & 8.3 & 9.2 & 9.6 & 10.4 & -. & $\ldots$ & $\ldots$ & 9.2 & $\ldots$ & $\ldots$ & ... \\
\hline Private sector credivGDP & 3.9 & 3.6 & 3.9 & 3.8 & $\ldots$ & $\ldots$ & -.. & 4.4 & $\ldots$ & $\ldots$ & $\ldots$ \\
\hline Currency outside banks/GDP & 4.6 & 5.3 & 5.0 & 5.5 & $\ldots$ & $\ldots$ & $\ldots$ & 4.7 & $\ldots$ & $\ldots$ & $\ldots$ \\
\hline Currency/deporits & 122.1 & 135.2 & 107.9 & 112.2 & 107.4 & 107.1 & 98.6 & 103.3 & 96.7 & 95.2 & 84.8 \\
\hline
\end{tabular}

Sources: Data provided by the Guinean authorities; and stafl estimates.

1/ Including transactions with the former Soviet Union.

2/ Data on private sector credit have been revised to take into account provisioned nonperforming loans, which were previously recorded within other items net. The stock of private sector eredit was reduced by GF 10 billion at end - 1991 for debt write- ofts. The restructuring of commercial banks in 1993 entriled debt write - offs amounting wo about GF 11 billion in October 1993. with a correction in other items net (red uetion of nonperforming loans).

3/ The GDP figures are based on revised national aceounts data since 1986, which entailed a substantial decline in nominal GDP. thus making ratios to GDP not direetly comparable to dau reported in earliet fund documents. 
Table 10. Guinea: Summary Accounts of the Central Bank, 1990-95 1 '

\begin{tabular}{|c|c|c|c|c|c|c|c|c|c|c|c|}
\hline & \multirow[t]{2}{*}{1990} & \multirow[t]{2}{*}{1991} & \multirow[t]{2}{*}{1992} & \multirow[t]{2}{*}{1993} & \multicolumn{4}{|c|}{1994} & \multicolumn{3}{|c|}{1995} \\
\hline & & & & & Mar. & June & Sep. & Dec. & Mar. & June & Sep. \\
\hline & \multicolumn{11}{|c|}{ (In billions of Guinean franes: end of period) } \\
\hline Net foreign assels & 44.3 & 57.0 & 74.2 & 123.7 & 94.0 & 98.0 & 83.6 & 88.1 & 89.6 & 112.3 & 115.0 \\
\hline $\begin{array}{l}\text { Gold } \\
\text { IMF. net }\end{array}$ & $\begin{array}{r}52.3 \\
-34.9\end{array}$ & $\begin{array}{r}48.0 \\
-44.1\end{array}$ & $\begin{array}{r}67.4 \\
-58.8\end{array}$ & $\begin{array}{r}59.8 \\
-59.1\end{array}$ & $\begin{array}{r}71.3 \\
-58.6\end{array}$ & $\begin{array}{r}67.8 \\
-60.1\end{array}$ & $\begin{array}{r}76.6 \\
-57.2\end{array}$ & $\begin{array}{r}77.9 \\
-69.1\end{array}$ & $\begin{array}{r}92.7 \\
-70.2\end{array}$ & $\begin{array}{r}103.4 \\
-84.3\end{array}$ & $\begin{array}{r}123.6 \\
-77.4\end{array}$ \\
\hline $\begin{array}{l}\text { SDR holdings (at eurrent } \\
\text { exchange rates) } \\
\text { Poreign exchange holdings } \\
\text { Vnesheconombank. Moscow } \\
\text { Short - term liabilities }\end{array}$ & $\begin{array}{r}0.2 \\
26.1 \\
8.1 \\
-7.6\end{array}$ & $\begin{array}{r}10.8 \\
52.5 \\
0.0 \\
-10.3\end{array}$ & $\begin{array}{r}10.1 \\
65.4 \\
3.6 \\
-13.6\end{array}$ & $\begin{array}{r}11.4 \\
114.4 \\
1.7 \\
-4.4\end{array}$ & $\begin{array}{r}9.9 \\
77.4 \\
1.7 \\
-7.7\end{array}$ & $\begin{array}{r}9.8 \\
83.1 \\
1.7 \\
-4.3\end{array}$ & $\begin{array}{r}5.8 \\
64.0 \\
1.7 \\
-7.4\end{array}$ & $\begin{array}{r}5.4 \\
77.8 \\
1.8 \\
-5.6\end{array}$ & $\begin{array}{r}1.1 \\
73.8 \\
1.8 \\
-9.5\end{array}$ & $\begin{array}{r}1.1 \\
94.6 \\
1.7 \\
-4.2\end{array}$ & $\begin{array}{r}0.5 \\
70.8 \\
1.8 \\
-4.3\end{array}$ \\
\hline Net domestic assets & 53.1 & 85.0 & 4.5 & 65.3 & 68.2 & 65.6 & 68.3 & 85.2 & 84.1 & 82.3 & 74.1 \\
\hline \multirow{6}{*}{$\begin{array}{l}\text { Net domestic credit } \\
\text { Public sector (net) } \\
\text { Government } \\
\text { Of which: OBK 2y } \\
\text { Public enterprises (net) } \\
\text { Private sector } \\
\text { Refinancing (net) }\end{array}$} & $\begin{array}{l}39.1 \\
23.3\end{array}$ & $\begin{array}{l}66.6 \\
51.0\end{array}$ & $\begin{array}{l}71.9 \\
61.6\end{array}$ & $\begin{array}{l}51.9 \\
43.6\end{array}$ & $\begin{array}{l}55.4 \\
46.5\end{array}$ & $\begin{array}{l}53.8 \\
45.4\end{array}$ & $\begin{array}{l}66.9 \\
58.1\end{array}$ & $\begin{array}{l}79.5 \\
70.8\end{array}$ & $\begin{array}{l}74.6 \\
65.7\end{array}$ & $\begin{array}{l}73.2 \\
64.9\end{array}$ & $\begin{array}{l}72.5 \\
64.6\end{array}$ \\
\hline & 33.4 & 53.4 & 65.1 & 46.1 & 46.0 & 45.2 & 57.3 & 68.7 & 65.6 & 62.3 & 62.3 \\
\hline & $(-9.1)$ & $(0.9)$ & $(5.0)$ & (13.4) & (13.4) & (13.4) & (13.4) & (13.4) & (13.4) & (13.4) & (13.4) \\
\hline & -10.1 & -2.4 & -3.5 & -2.5 & 0.5 & 0.2 & 0.8 & 2.1 & 0.1 & 2.6 & 2.2 \\
\hline & 0.0 & 0.2 & 0.4 & 0.0 & 0.3 & 0.4 & 0.2 & 0.1 & 0.6 & 0.4 & 0.3 \\
\hline & 15.8 & 15.4 & 9.9 & 8.2 & 8.6 & 8.0 & 8.6 & 8.6 & 8.3 & 7.8 & 7.7 \\
\hline \multirow{8}{*}{$\begin{array}{l}\text { Other assets and liabilities } \\
\text { Revalustion accounts } \\
\text { Adjustment IMF accounts } \\
\text { Capital and reserves } \\
\text { SDR allocations } \\
\text { Demand deporits in GF } \\
\text { Foreign eurrency deposits } \\
\text { Other (net) }\end{array}$} & 14.0 & 18.4 & 12.6 & 13.4 & 12.9 & 11.9 & 1.4 & 5.7 & 9.5 & 9.1 & 1.5 \\
\hline & 20.4 & 29.9 & 20.8 & 24.4 & 24.4 & 23.2 & 22.4 & 21.6 & 20.3 & 20.4 & 19.4 \\
\hline & 4.9 & 16.3 & 26.2 & 24.7 & 23.5 & 24.8 & 23.4 & 23.3 & 24.6 & 22.0 & 20.5 \\
\hline & -7.3 & -11.3 & -11.3 & -152 & -15.2 & -15.2 & -20.8 & -19.4 & -25.6 & -25.6 & -24.3 \\
\hline & -5.8 & -5.8 & -5.8 & -5.8 & -5.8 & -5.8 & -5.8 & -5.8 & -5.8 & -5.8 & -5.8 \\
\hline & -1.3 & -2.3 & -2.2 & -2.1 & -1.4 & -1.3 & -1.5 & -2.2 & -1.5 & -1.6 & -2.7 \\
\hline & -0.2 & -2.0 & -0.0 & -0.0 & -0.0 & -0.0 & -1.4 & -0.0 & -0.1 & -0.1 & -0.1 \\
\hline & 3.3 & -6.4 & -15.2 & -12.6 & -12.6 & -13.8 & -14.9 & -11.7 & -2.5 & -0.3 & -5.5 \\
\hline Reserve money & 95.9 & 137.7 & 156.4 & 189.0 & 162.3 & 163.6 & 151.9 & 173.3 & 173.7 & 194.6 & 189.1 \\
\hline \multirow{4}{*}{$\begin{array}{l}\text { Currency outside bonks } \\
\text { Deposit bank reserves } \\
\text { Deposits at the BCRG } \\
\text { Currency holdings }\end{array}$} & 84.7 & 119.4 & 133.0 & 166.6 & 150.5 & 147.7 & 138.1 & 154.8 & 153.0 & 164.2 & 157.5 \\
\hline & 11.2 & 18.3 & 23.4 & 22.4 & 11.7 & 16.0 & 13.8 & 18.6 & 20.7 & 30.4 & 31.6 \\
\hline & 9.8 & 262 & 17.4 & 16.2 & 8.0 & 11.7 & 9.5 & 12.5 & 14.8 & 23.7 & 26.0 \\
\hline & 1.4 & 2.1 & 6.0 & 6.2 & 3.7 & 4.3 & 4.3 & 6.0 & 5.9 & 6.7 & 5.6 \\
\hline \multicolumn{5}{|l|}{ Memorandum ltems } & \multicolumn{3}{|c|}{ (In percent) } & & & & \\
\hline \multirow{3}{*}{$\begin{array}{l}\text { Reserve money, annual percentage } \\
\text { change } \\
\text { Broad money/Reserve money } \\
\text { Currency outside banka/Reserve } \\
\text { money }\end{array}$} & & & & & & & & & & & 24.5 \\
\hline & 149.9 & 150.8 & 163.9 & 166.7 & 179.2 & 174.5 & $\begin{array}{r}-13.0 \\
183.1\end{array}$ & 175.7 & 179.2 & 173.0 & $\begin{array}{r}281.3 \\
181.4\end{array}$ \\
\hline & 88.3 & 86.7 & 85.0 & 88.2 & 92.8 & 90.2 & 90.9 & 89.3 & 88.1 & 84.4 & 83.3 \\
\hline
\end{tabular}

Sources: Data provided by the Guinean suthorities; and staff eximates.

1/ Including transactions with the former Soviet Union.

2/ Kindi Baurite Office, which was a government department until end - 1992. 
Table 11. Guinea: Summary Accounts of Deposit Money Banks, 1990-95 $1 /$

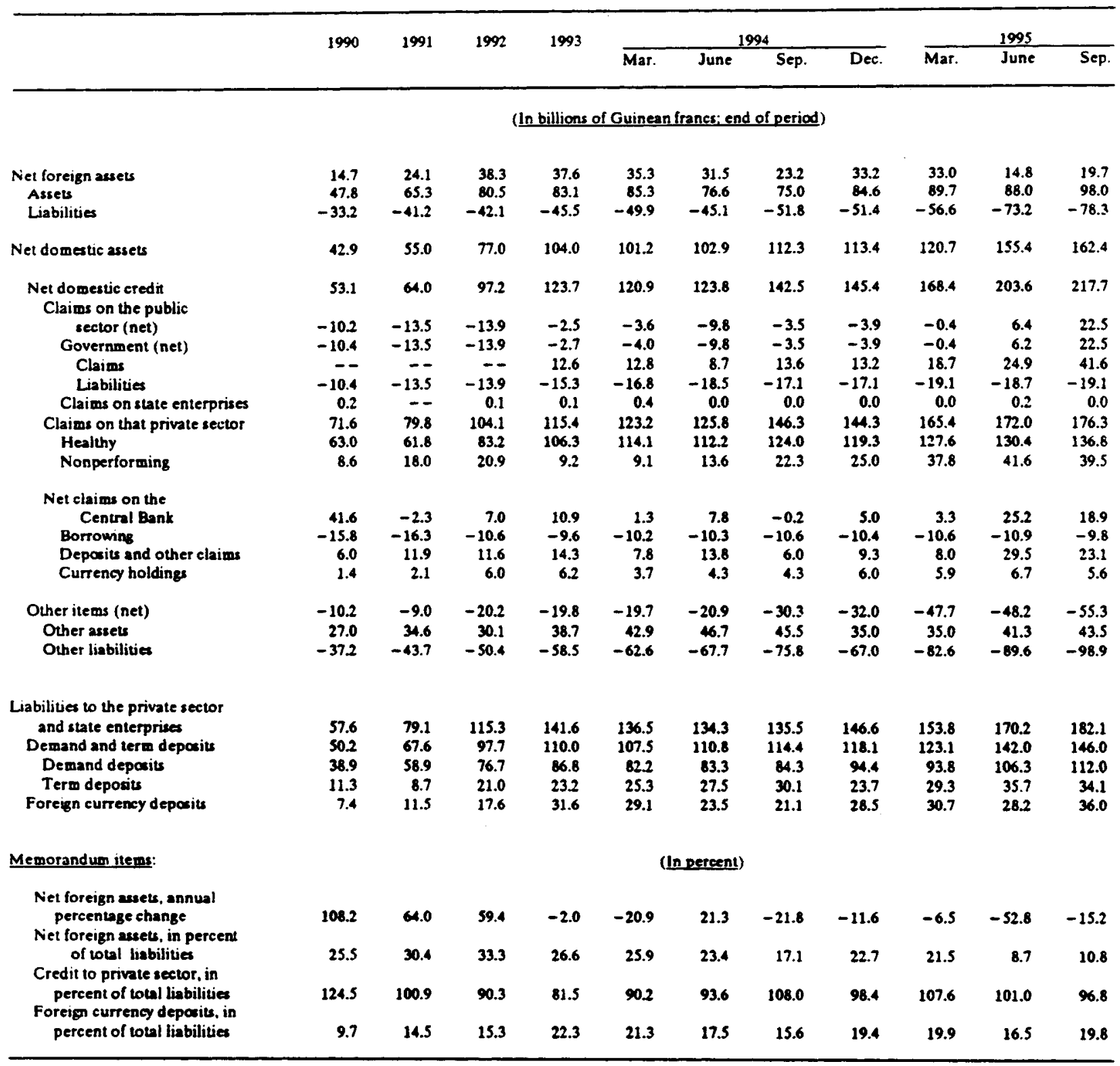

Sowces: Data provided by the Guinean authorities: and staff estimates.

1/ Including transactions with the former Soviet Union. 
(Le percent per annuge)

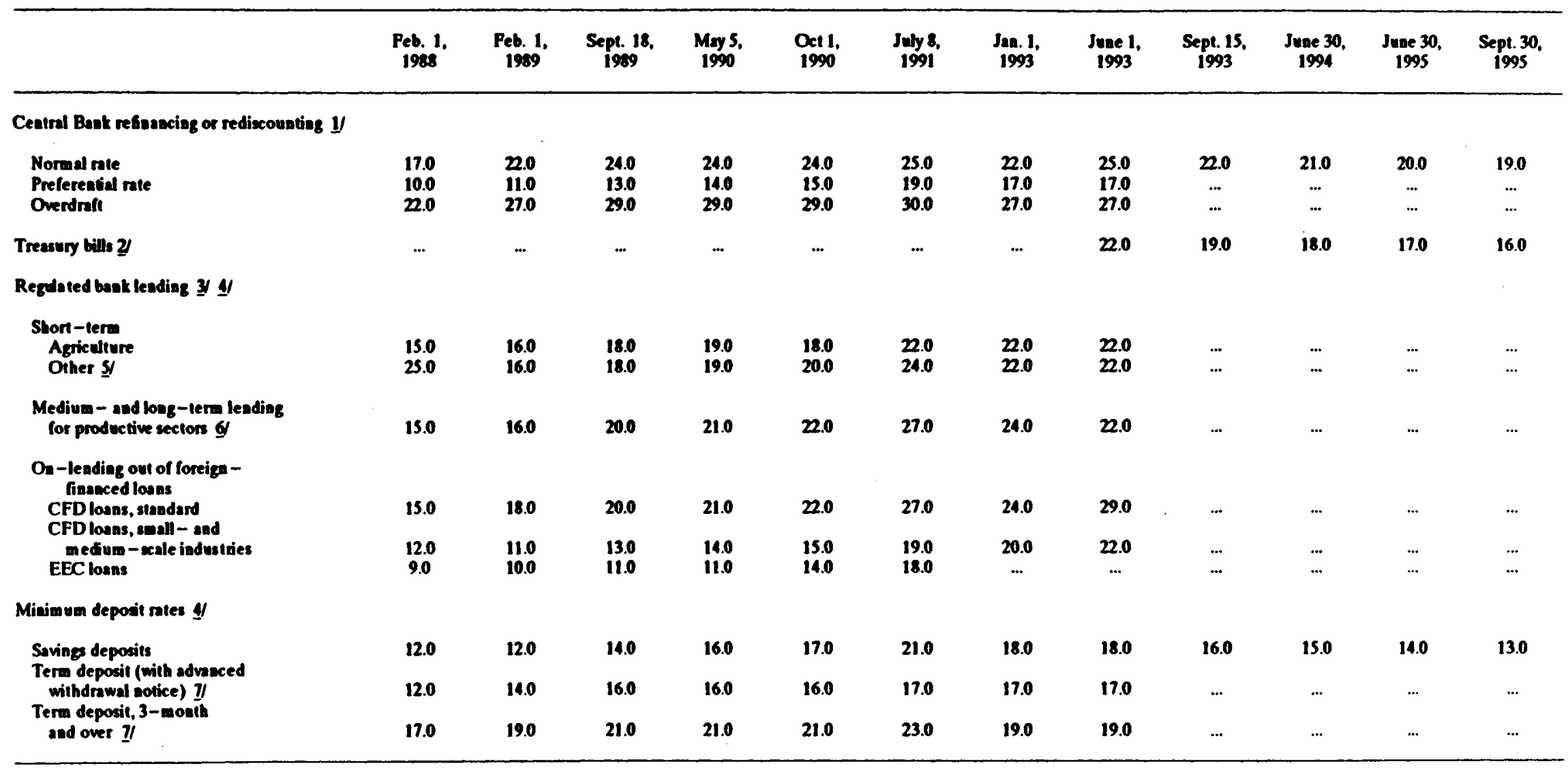

Source: Data provided by the Central Bant of Ouises.

1) Since June 1993, central baak refinancing bas beea discontiaued, acept for a limited number of onlent donor lines of credit. Siace thea, the Central Bank rediscounts only treasury bills at a rate set at 3 perentage poists above the previling treasury bill rate.

21 Introduced in June 1993, and issued at woathly auctions sioce December 1993.

Interest mete ceiling on lending eligible for preferential refinascing undl June 1993.

1) Since June 1993, the controls on bank deposit and lending rates have been lifted. The banks are free to determiae their rates subject a merim um limit of 12 percentage points - Sice Jeasury bill rate forlending rates and a minim um limit for the savipgs deposit rale, set at 3 percentage points below the treasury bill rate.

S) Mainly for aports. Rales on non-refianceable short-term loans were deregulated with effect from February 1, 1989.

Small- and medium - scale industries, and agriculture.

I) Subject 10 a minim um deposil of GF 3 million. 
Table 13. Guinea: Balance of Payments, 1988-94 $1 /$

(In millions of U.S. dollars, unless otherwise indicated)

\begin{tabular}{|c|c|c|c|c|c|c|c|}
\hline & 1988 & 1989 & 1990 & 1991 & 1992 & 1993 & $\frac{1994}{E s L}$ \\
\hline Trade balance & $\underline{5.5}$ & $\underline{144.2}$ & $\underline{93.5}$ & $\underline{55.3}$ & -83.1 & -65.8 & $=61.1$ \\
\hline $\begin{array}{l}\text { Exports (f.ob.) } 2 / \\
\text { Mining exports } \\
\text { Other }\end{array}$ & $\begin{array}{r}609.1 \\
573.7 \\
35.4\end{array}$ & $\begin{array}{r}731.1 \\
677.1 \\
54.1\end{array}$ & $\begin{array}{r}816.7 \\
756.2 \\
60.6\end{array}$ & $\begin{array}{r}790.2 \\
719.3 \\
70.8\end{array}$ & $\begin{array}{r}656.8 \\
577.4 \\
79.4\end{array}$ & $\begin{array}{r}665.0 \\
574.7 \\
90.4\end{array}$ & $\begin{array}{l}625.9 \\
498.5 \\
127.4\end{array}$ \\
\hline $\begin{array}{l}\text { Imports (ci.f.) } 3 \text { / } \\
\text { Public rector } \\
\text { Mining companies } \\
\text { Other private }\end{array}$ & $\begin{array}{l}-603.6 \\
-159.8 \\
-151.8 \\
-292.0\end{array}$ & $\begin{array}{l}-586.9 \\
-162.1 \\
-140.5 \\
-284.3\end{array}$ & $\begin{array}{l}-723.2 \\
-168.0 \\
-230.3 \\
-324.9\end{array}$ & $\begin{array}{l}-734.9 \\
-153.8 \\
-256.4 \\
-324.8\end{array}$ & $\begin{array}{l}-739.9 \\
-152.6 \\
-234.2 \\
-353.1\end{array}$ & $\begin{array}{l}-730.9 \\
-146.6 \\
-217.9 \\
-366.4\end{array}$ & $\begin{array}{l}-687.0 \\
-138.2 \\
-152.6 \\
-396.2\end{array}$ \\
\hline $\begin{array}{l}\text { Services, net } \\
\text { Of which: intereat due } \\
\text { Private transfers } \\
\text { Official transfers }\end{array}$ & $\begin{array}{r}-283.2 \\
(-106.8) \\
-24.9 \\
83.5\end{array}$ & $\begin{array}{c}-317.5 \\
(-99.4) \\
-42.9 \\
98.0\end{array}$ & $\begin{array}{c}-299.7 \\
(-100.9) \\
-50.6 \\
100.9\end{array}$ & $\begin{array}{l}-260.6 \\
(-92.1) \\
-42.2 \\
109.5\end{array}$ & $\begin{array}{c}-220.6 \\
(-69.3) \\
-63.5 \\
135.6\end{array}$ & $\begin{array}{c}-219.4 \\
(-65.9) \\
-54.3 \\
117.9\end{array}$ & $\begin{array}{r}-212.9 \\
(-73.6) \\
-40.9 \\
120.2\end{array}$ \\
\hline $\begin{array}{l}\text { Curreat account balance } \\
\text { lncluding official transfers } \\
\text { Excluding ofricial transfers }\end{array}$ & $\begin{array}{r}-219.0 \\
-30.5 \\
\end{array}$ & $\begin{array}{r}-118.2 \\
-216.2 \\
\end{array}$ & $\begin{array}{l}-155.8 \\
-256.7 \\
\end{array}$ & $\begin{array}{l}-138.1 \\
-247.5 \\
\end{array}$ & $\begin{array}{r}-231.5 \\
-367.1 \\
\end{array}$ & $\begin{array}{l}-221.7 \\
-339.6 \\
\end{array}$ & $\begin{array}{l}-194.6 \\
-314.9 \\
\end{array}$ \\
\hline $\begin{array}{l}\text { Capital movements } \\
\text { Public, medium- and long -term, net } \\
\text { Project-related loans } \\
\text { Program loans } \\
\text { Amortization due- } \\
\text { Public, sbort term } \\
\text { Mining companies } \\
\text { Private direct inveatment } \\
\text { Otber private capital } \\
\text { Errors add omianions }\end{array}$ & $\begin{array}{r}\frac{76.4}{51.9} \\
(146.4) \\
(46.9) \\
(-141.4) \\
--\overline{18.0} \\
6.5 \\
-\overline{15.1}\end{array}$ & $\begin{array}{r}\frac{119.4}{93.0} \\
(153.5) \\
(60.7) \\
(-121.1) \\
\overline{16.4} \\
10.0 \\
-\overline{-} \\
-29.3\end{array}$ & $\begin{array}{r}\frac{113.1}{61.0} \\
(181.2) \\
(3.8) \\
(-124.1) \\
11.3 \\
29.9 \\
10.9 \\
-5.0\end{array}$ & $\begin{array}{r}\frac{106.0}{52.0} \\
(175.1) \\
(32.4) \\
(-155.4) \\
-1.2 \\
43.8 \\
11.4 \\
--\overline{-} \\
-35.6\end{array}$ & $\begin{array}{r}\frac{156.5}{61.8} \\
(160.2) \\
(30.4) \\
(-128.8) \\
-1.2 \\
83.4 \\
12.6 \\
-7.5 \\
-7.5\end{array}$ & $\begin{array}{r}\frac{189.1}{105.1} \\
(150.5) \\
(52.5) \\
(-97.9) \\
-4.5 \\
62.7 \\
15.8 \\
10.0 \\
21.1\end{array}$ & $\begin{array}{r}\frac{50.9}{-7.7} \\
(131.6) \\
(7.7) \\
(-146.9) \\
-4.5 \\
24.6 \\
25.9 \\
12.6 \\
--\end{array}$ \\
\hline Overall balance & -127.6 & -28.0 & -37.7 & -67.6 & -8.5 & -11.4 & -143.7 \\
\hline $\begin{array}{l}\text { Financing items } \\
\text { Official reserves, net } \\
\text { Of which: IMF credit, wet } \\
\text { Changes in arrears, net } \\
\text { Debt relief } \\
\text { Deferred payments }\end{array}$ & $\begin{array}{c}127.6 \\
26.9 \\
(-5.4) \\
77.5 \\
23.2 \\
--\end{array}$ & $\begin{array}{r}28.0 \\
-21.7 \\
(13.7) \\
-26.1 \\
75.8 \\
--\end{array}$ & $\begin{array}{r}37.7 \\
-50.7 \\
(-14.2) \\
27.9 \\
60.5 \\
--\end{array}$ & $\begin{array}{c}67.6 \\
-18.2 \\
(3.2) \\
9.3 \\
76.5 \\
--\end{array}$ & $\begin{array}{r}82.5 \\
-3.3 \\
(11.0) \\
-329.6 \\
384.4 \\
31.0\end{array}$ & $\begin{array}{r}11.4 \\
-49.3 \\
(-3.2) \\
79.3 \\
58.9 \\
-77.5\end{array}$ & $\begin{array}{r}143.7 \\
34.4 \\
(6.6) \\
109.3 \\
-- \\
--\end{array}$ \\
\hline \multicolumn{8}{|l|}{ Memorandum items: } \\
\hline $\begin{array}{l}\text { Current account balance/GDP } \\
\text { Including official transfers } \\
\text { Excluding official transfers }\end{array}$ & $\begin{array}{r}-92 \\
-12.7\end{array}$ & $\begin{array}{l}-4.9 \\
-8.9\end{array}$ & $\begin{array}{l}-5.5 \\
-9.1\end{array}$ & $\begin{array}{l}-4.6 \\
-8.3\end{array}$ & $\begin{array}{r}-7.8 \\
-12.3\end{array}$ & $\begin{array}{r}-7.0 \\
-10.7\end{array}$ & $\begin{array}{l}-5.7 \\
-9.3\end{array}$ \\
\hline $\begin{array}{l}\text { Net reserves, excluding IMF } \\
\text { Gross official reserves } \\
\text { Foreign exchange } \\
\text { Gold } \\
\text { Short-term linbilities }\end{array}$ & $\begin{array}{r}32.7 \\
43.1 \\
12.0 \\
31.2 \\
-10.4\end{array}$ & $\begin{array}{r}68.1 \\
2.6 \\
27.5 \\
45.1 \\
-4.5\end{array}$ & $\begin{array}{r}104.6 \\
115.7 \\
38.7 \\
77.0 \\
-11.1\end{array}$ & $\begin{array}{r}125.9 \\
138.7 \\
78.9 \\
59.8 \\
-12.8\end{array}$ & $\begin{array}{r}140.2 \\
154.9 \\
81.8 \\
73.1 \\
-14.7\end{array}$ & $\begin{array}{r}186.3 \\
190.8 \\
129.3 \\
61.5 \\
-4.5\end{array}$ & $\begin{array}{r}158.5 \\
164.2 \\
84.8 \\
79.4 \\
-5.7\end{array}$ \\
\hline $\begin{array}{l}\text { Grose reserves, in months of } \\
\text { noumining imports } \\
\text { total imports }\end{array}$ & $\begin{array}{l}1.1 \\
0.9\end{array}$ & $\begin{array}{l}2.0 \\
1.5\end{array}$ & $\begin{array}{l}2.8 \\
1.9\end{array}$ & $\begin{array}{l}3.5 \\
2.3\end{array}$ & $\begin{array}{l}3.7 \\
2.5\end{array}$ & $\begin{array}{l}4.5 \\
3.1\end{array}$ & $\begin{array}{l}3.7 \\
2.9\end{array}$ \\
\hline
\end{tabular}

Sources: Data provided by the Guinean authorities; and staff eatimates.

1/ Including traneactions with the former Soviet Uaion.

$2 /$ Exports bave been redefined wo include exparts of gold by the Central Bank, previously reconded as "monetized gold" in the capital account. The current sccount deficit bas been revised sccordingly.

3 Within lotal imports, the reclavification of petroleum imports was shifted from public to private imports. with effect from the estimated outturn for 1992 oaward. 
Table 14. Guinea: Composition of Expors, 1988-94 $1 /$

(ln millions of U.S. dollars, unless otherwize indicated)

\begin{tabular}{|c|c|c|c|c|c|c|c|}
\hline & 1988 & 1989 & 1990 & 1991 & 1992 & 1993 & $\frac{1994}{\text { Est. }}$ \\
\hline $\begin{array}{l}\text { Total exports, f.o.b. } \\
\text { Mining compenies } 2 / \\
\text { Other }\end{array}$ & $\begin{array}{l}\frac{609.1}{500.7} \\
108.5\end{array}$ & $\begin{array}{l}\frac{731.1}{615.1} \\
116.1\end{array}$ & $\begin{array}{l}\frac{816.7}{678.6} \\
138.2\end{array}$ & $\begin{array}{l}\frac{790.2}{644.3} \\
145.8\end{array}$ & $\begin{array}{l}\frac{656.8}{498.6} \\
158.2\end{array}$ & $\begin{array}{l}\frac{665.0}{466.4} \\
198.6\end{array}$ & $\begin{array}{l}\frac{625.9}{374.9} \\
251.0\end{array}$ \\
\hline $\begin{array}{l}\text { Baurite } \\
\text { CBGG } \\
\text { Volume (million tons) } \\
\text { Price (USS per ton) } \\
\text { SBK } \\
\text { Volume (million tons) } \\
\text { Price (USS per ton) }\end{array}$ & $\begin{array}{l}358.9 \\
277.8 \\
(11.1) \\
(25.0) \\
81.1 \\
(32) \\
(25.5)\end{array}$ & $\begin{array}{l}415.1 \\
330.9 \\
(11.3) \\
(29.3) \\
84.2 \\
(3.2) \\
(26.6)\end{array}$ & $\begin{array}{l}447.4 \\
367.0 \\
(10.6) \\
(34.8) \\
80.4 \\
(3.0) \\
(27.0)\end{array}$ & $\begin{array}{l}434.7 \\
358.6 \\
(10.9) \\
(32.9) \\
76.0 \\
(2.8) \\
(26.9)\end{array}$ & $\begin{array}{l}343.3 \\
316.8 \\
(10.8) \\
(29.3) \\
26.5 \\
(1.1) \\
(24.8)\end{array}$ & $\begin{array}{l}323.7 \\
288.6 \\
(11.3) \\
(25.6) \\
35.1 \\
(2.4) \\
(14.5)\end{array}$ & $\begin{array}{l}271.5 \\
259.6 \\
(11.1) \\
(23.4) \\
11.8 \\
(1.1) \\
(11.0)\end{array}$ \\
\hline $\begin{array}{l}\text { Alumina (Friguia) } \\
\text { Volume (thousand tons) } \\
\text { Price (USS per ton) }\end{array}$ & $\begin{array}{r}92.7 \\
(592.7) \\
(156.4)\end{array}$ & $\begin{array}{l}130.5 \\
(623.7) \\
(209.2)\end{array}$ & $\begin{array}{l}166.3 \\
(631.8) \\
(2632)\end{array}$ & $\begin{array}{l}153.6 \\
(631.8) \\
(243.0)\end{array}$ & $\begin{array}{l}106.6 \\
(561.3) \\
(189.9)\end{array}$ & $\begin{array}{l}108.9 \\
(655.5) \\
(166.1)\end{array}$ & $\begin{array}{l}103.4 \\
(640.0) \\
(161.6)\end{array}$ \\
\hline $\begin{array}{l}\text { Diamonds } \\
\text { Aredor } \\
\text { Volume (thousand carats) } \\
\text { Price (USS per carat) } \\
\text { Other }\end{array}$ & $\begin{array}{c}76.7 \\
45.6 \\
(117.1) \\
(389.0) \\
31.1\end{array}$ & $\begin{array}{c}83.7 \\
56.2 \\
(163.0) \\
(344.6) \\
27.6\end{array}$ & $\begin{array}{c}70.0 \\
45.3 \\
(146.9) \\
(309.0) \\
24.7\end{array}$ & $\begin{array}{c}66.7 \\
40.7 \\
(125.3) \\
(325.0) \\
26.0\end{array}$ & $\begin{array}{c}67.0 \\
31.5 \\
(85.0) \\
(370.4) \\
35.6\end{array}$ & $\begin{array}{c}70.0 \\
33.9 \\
(91.8) \\
(3692) \\
36.2\end{array}$ & $\begin{array}{c}40.2 \\
\overline{-} \\
(372.9) \\
40.2\end{array}$ \\
\hline $\begin{array}{l}\text { Gold } \\
\text { SAG } \\
\text { Volume (tons) } \\
\text { Price (USS per ounce) } \\
\text { Other } \\
\text { Central Bank of Guinea } 3 \text { / } \\
\text { Volume (tons) }\end{array}$ & $\begin{array}{c}45.4 \\
3.5 \\
(0.3) \\
(371.3) \\
30.1 \\
11.9 \\
(1.3)\end{array}$ & $\begin{array}{c}47.7 \\
13.3 \\
(1.1) \\
(361.1) \\
26.1 \\
8.3 \\
(1.5)\end{array}$ & $\begin{array}{c}72.5 \\
19.6 \\
(1.7) \\
(355.3) \\
25.6 \\
27.3 \\
(3.0)\end{array}$ & $\begin{array}{c}64.4 \\
15.4 \\
(1.5) \\
(326.1) \\
13.6 \\
35.4 \\
(3.6)\end{array}$ & $\begin{array}{r}60.5 \\
172 \\
(1.6) \\
(345.0) \\
7.8 \\
35.5 \\
(3.7)\end{array}$ & $\begin{array}{c}72.1 \\
\overline{-} \\
-\overline{-} \\
(360.0) \\
142 \\
57.9 \\
(5.0)\end{array}$ & $\begin{array}{r}83.5 \\
-- \\
\overline{-} \\
(380.0) \\
21.0 \\
62.5 \\
(5.0)\end{array}$ \\
\hline $\begin{array}{l}\text { Coffee } \\
\text { Volume (thourend tons) } \\
\text { Price (USS per ton) }\end{array}$ & $\begin{array}{r}15.7 \\
(7.5) \\
(2,0968)\end{array}$ & $\begin{array}{r}23.1 \\
(11.0) \\
(2,0968)\end{array}$ & $\begin{array}{r}22.0 \\
(13.2) \\
(1.665 .1)\end{array}$ & $\begin{array}{r}23.4 \\
(152) \\
(1.544 .0)\end{array}$ & $\begin{array}{r}25.8 \\
(17.5) \\
(1,474.0)\end{array}$ & $\begin{array}{r}36.6 \\
(20.6) \\
(1,775.5)\end{array}$ & $\begin{array}{r}56.7 \\
(24.2) \\
(2.3427)\end{array}$ \\
\hline $\begin{array}{l}\text { Fish } \\
\text { Volume (thourand tons) } \\
\text { Price (USS per ton) }\end{array}$ & $\begin{array}{r}3.5 \\
(5.0) \\
(690.0)\end{array}$ & $\begin{array}{c}11.3 \\
(15.0) \\
(750.0)\end{array}$ & $\begin{array}{c}13.6 \\
(18.0) \\
(7555)\end{array}$ & $\begin{array}{c}17.4 \\
(20.7) \\
(839.9)\end{array}$ & $\begin{array}{c}19.1 \\
(22.0) \\
(867.0)\end{array}$ & $\begin{array}{c}16.6 \\
(25.3) \\
(656.5)\end{array}$ & $\begin{array}{c}19.7 \\
(29.1) \\
(678.1)\end{array}$ \\
\hline Otber exports 4 & 162 & 19.7 & 25.0 & 30.0 & 34.5 & 372 & 51.0 \\
\hline \multicolumn{8}{|l|}{ Memorandum items: } \\
\hline $\begin{array}{l}\text { Expors, } 1989 \text { prices } \\
\text { Percentage change }\end{array}$ & $\begin{array}{c}678.5 \\
(3.6)\end{array}$ & $\begin{array}{c}731.1 \\
(7.8)\end{array}$ & $\begin{array}{r}742.6 \\
(1.6)\end{array}$ & $\begin{array}{c}760.1 \\
(2.4)\end{array}$ & $\begin{array}{l}693.9 \\
(-8.7)\end{array}$ & $\begin{array}{l}7932 \\
(14.3)\end{array}$ & $\begin{array}{c}741.0 \\
(-6.6)\end{array}$ \\
\hline $\begin{array}{l}\text { Export prices, 1989= } 100 \\
\text { Percentage change }\end{array}$ & $\begin{array}{c}89.8 \\
(-7.4)\end{array}$ & $\begin{array}{l}100.0 \\
(11.4)\end{array}$ & $\begin{array}{l}110.0 \\
(10.0)\end{array}$ & $\begin{array}{l}104.0 \\
(-5.5)\end{array}$ & $\begin{array}{c}94.7 \\
(-9.0)\end{array}$ & $\begin{array}{c}83.8 \\
(-11.4)\end{array}$ & $\begin{array}{l}84.5 \\
(0.8)\end{array}$ \\
\hline $\begin{array}{l}\text { Exports/GDP } \\
\text { Mining companies } \\
\text { Other }\end{array}$ & $\begin{array}{r}25.5 \\
21.0 \\
4.5\end{array}$ & $\begin{array}{r}30.1 \\
25.3 \\
4.8\end{array}$ & $\begin{array}{r}29.0 \\
24.1 \\
4.9\end{array}$ & $\begin{array}{r}26.5 \\
21.6 \\
4.9\end{array}$ & $\begin{array}{r}22.1 \\
16.8 \\
5.3\end{array}$ & $\begin{array}{r}20.9 \\
14.7 \\
6.3\end{array}$ & $\begin{array}{r}18.4 \\
11.0 \\
7.4\end{array}$ \\
\hline
\end{tabular}

Sources: Dala provided by the Guinean authoritiex; and staff eatimates.

1/ Including transactions with the former Soviet Union.

2/ Comprise the Compagaie des Bavites de Guince (CBG), Societte des Baurites de Kindia (SBK--Iormerty OBK), Friguia (alumina producer), Artor (diamond mine), and Socicte Auriftere de Guines (roid mine--SAG).

3/ Gold exports by the Central Bant of Guinea were previously recorded as "monetized gold" in the capital sccount.

4 Conprising mainly lood products. 
Table 15. Guinea: Composition of Imports, 1988-94 1/

(In millions of U.S. dollars, uniess othenwise indicated)

\begin{tabular}{|c|c|c|c|c|c|c|c|}
\hline & 1988 & 1989 & 1990 & 1991 & 1992 & 1993 & $\frac{1994}{\text { Est. }}$ \\
\hline Total imports, c.i.f. & $\underline{603.6}$ & $\underline{586.9}$ & $\underline{723.2}$ & $\underline{734.9}$ & $\underline{739.9}$ & $\underline{730.9}$ & $\underline{687.0}$ \\
\hline $\begin{array}{l}\text { Public sector } \\
\text { Food aid } \\
\text { Public investment program } \\
\text { Central Government and } \\
\text { public enterprises }\end{array}$ & $\begin{array}{r}159.8 \\
10.0 \\
89.1 \\
60.8\end{array}$ & $\begin{array}{r}162.1 \\
10.0 \\
94.3 \\
57.8\end{array}$ & $\begin{array}{r}168.0 \\
8.0 \\
112.9\end{array}$ & \begin{tabular}{r|}
153.8 \\
3.8 \\
105.5
\end{tabular} & $\begin{array}{r}152.6 \\
4.2 \\
111.5\end{array}$ & $\begin{array}{r}146.6 \\
5.6 \\
119.0 \\
22.0\end{array}$ & $\begin{array}{r}138.2 \\
5.4 \\
109.9 \\
22.9\end{array}$ \\
\hline Mining companies & 151.8 & 140.5 & 230.3 & 256.4 & 234.2 & 217.9 & 152.6 \\
\hline $\begin{array}{l}\text { Otber private sector } 2 / \\
\text { Of which: oil products }\end{array}$ & $\begin{array}{l}292.0 \\
(21.5)\end{array}$ & $\begin{array}{l}284.3 \\
(20.5)\end{array}$ & $\begin{array}{l}324.9 \\
(25.7)\end{array}$ & $\begin{array}{l}324.8 \\
(28.4)\end{array}$ & $\begin{array}{l}353.1 \\
(32.6)\end{array}$ & $\begin{array}{l}366.4 \\
(31.7)\end{array}$ & $\begin{array}{l}396.2 \\
(32.9)\end{array}$ \\
\hline \multicolumn{8}{|l|}{ Memorandum items: } \\
\hline $\begin{array}{l}\text { Imports, } 1989 \text { prices } \\
\text { Percentage change }\end{array}$ & $\begin{array}{l}611.1 \\
(16.2)\end{array}$ & $\begin{array}{l}586.9 \\
(-4.0)\end{array}$ & $\begin{array}{l}666.0 \\
(13.5)\end{array}$ & $\begin{array}{r}670.9 \\
(0.7)\end{array}$ & $\begin{array}{l}656.4 \\
(-2.2)\end{array}$ & $\begin{array}{r}687.3 \\
(4.7)\end{array}$ & $\begin{array}{c}610.0 \\
(-11.3)\end{array}$ \\
\hline $\begin{array}{l}\text { Imports, } 1989=100 \\
\text { Percentage change }\end{array}$ & $\begin{array}{l}98.8 \\
(3.8)\end{array}$ & $\begin{array}{l}100.0 \\
(1.2)\end{array}$ & $\begin{array}{c}108.6 \\
(8.6)\end{array}$ & $\begin{array}{r}109.5 \\
(0.9)\end{array}$ & $\begin{array}{r}112.7 \\
(2.9)\end{array}$ & $\begin{array}{l}106.3 \\
(-5.7)\end{array}$ & $\begin{array}{r}112.6 \\
(5.9)\end{array}$ \\
\hline $\begin{array}{l}\text { Imports/GDP } \\
\text { Mining companies } \\
\text { Other }\end{array}$ & $\begin{array}{r}25.3 \\
6.4 \\
18.9\end{array}$ & $\begin{array}{r}24.1 \\
5.8 \\
18.4\end{array}$ & $\begin{array}{r}25.7 \\
8.2 \\
17.5\end{array}$ & $\begin{array}{r}24.6 \\
8.6 \\
16.0\end{array}$ & $\begin{array}{r}24.9 \\
7.9 \\
17.0\end{array}$ & $\begin{array}{r}23.0 \\
6.9 \\
16.1\end{array}$ & $\begin{array}{r}20.2 \\
4.5 \\
15.7\end{array}$ \\
\hline $\begin{array}{l}\text { Terms of trade, } 1989=100 \\
\text { Percentage change }\end{array}$ & $\begin{array}{r}90.9 \\
-10.8\end{array}$ & $\begin{array}{r}100.0 \\
10.0\end{array}$ & $\begin{array}{r}101.3 \\
1.3\end{array}$ & $\begin{array}{r}94.9 \\
-6.3\end{array}$ & $\begin{array}{r}84.0 \\
-11.5\end{array}$ & $\begin{array}{r}78.8 \\
-6.1\end{array}$ & $\begin{array}{r}75.0 \\
-4.9\end{array}$ \\
\hline
\end{tabular}

Sources: Data provided by the Guinean authorities; and staff eatimates.

1/ Including transactions with the former Soviet Union.

2/ Also includes some public enterprise imports. 
Table 16. Guinea: Balance of Payments of the Mining Companies, 1988-94 1/

(In millions of U.S. dollars)

\begin{tabular}{|c|c|c|c|c|c|c|c|}
\hline & 1988 & 1989 & 1990 & 1991 & 1992 & 1993 & $\frac{1994}{\text { Est. }}$ \\
\hline $\begin{array}{l}\text { Trade balance } \\
\text { Exports, f.o.b. } \\
\text { Bauxite } \\
\text { Alumina } \\
\text { Gold and dia monds } \\
\text { Imports }\end{array}$ & $\begin{array}{r}348.9 \\
500.7 \\
358.9 \\
92.7 \\
49.0 \\
151.8\end{array}$ & $\begin{array}{r}474.6 \\
615.1 \\
415.1 \\
130.5 \\
69.4 \\
140.5\end{array}$ & $\begin{array}{r}448.3 \\
678.6 \\
447.4 \\
166.3 \\
64.9 \\
230.3\end{array}$ & $\begin{array}{r}388.0 \\
644.3 \\
434.7 \\
153.6 \\
56.1 \\
256.4\end{array}$ & $\begin{array}{r}264.4 \\
498.6 \\
343.3 \\
106.6 \\
48.7 \\
234.2\end{array}$ & $\begin{array}{r}248.5 \\
466.4 \\
323.7 \\
108.9 \\
33.9 \\
217.9\end{array}$ & $\begin{array}{r}222.3 \\
374.9 \\
271.5 \\
103.4 \\
-- \\
152.6\end{array}$ \\
\hline $\begin{array}{l}\text { Services and private } \\
\text { transfers, net } \\
\text { Of which: interest }\end{array}$ & $\begin{array}{l}139.3 \\
(27.7)\end{array}$ & $\begin{array}{l}182.6 \\
(36.0)\end{array}$ & $\begin{array}{l}162.3 \\
(26.1)\end{array}$ & $\begin{array}{l}132.0 \\
(18.9)\end{array}$ & $\begin{array}{l}113.7 \\
(14.2)\end{array}$ & $\begin{array}{l}112.3 \\
(23.2)\end{array}$ & $\begin{array}{c}89.4 \\
(17.3)\end{array}$ \\
\hline Current account & 209.6 & 292.0 & 286.0 & 256.0 & 150.7 & 136.2 & 132.9 \\
\hline $\begin{array}{l}\text { Capilal movements, net } \\
\text { Inflows } \\
\text { Amortization payments }\end{array}$ & $\begin{array}{r}18.0 \\
532 \\
-352\end{array}$ & $\begin{array}{r}16.4 \\
332 \\
-16.8\end{array}$ & $\begin{array}{r}29.9 \\
53.4 \\
-23.5\end{array}$ & $\begin{array}{r}43.8 \\
49.6 \\
-5.8\end{array}$ & $\begin{array}{r}83.4 \\
93.2 \\
-9.8\end{array}$ & $\begin{array}{r}62.7 \\
84.6 \\
-21.9\end{array}$ & $\begin{array}{r}24.6 \\
55.7 \\
-31.1\end{array}$ \\
\hline Overall balance & 227.6 & $\underline{308.4}$ & 315.9 & $\underline{299.8}$ & 234.0 & 198.9 & $\underline{157.5}$ \\
\hline \multicolumn{8}{|l|}{ Memorandum ilems: } \\
\hline $\begin{array}{l}\text { Curreat accounUGDP } \\
\text { Overall balance/GDP }\end{array}$ & $\begin{array}{l}8.8 \\
9.5\end{array}$ & $\begin{array}{l}12.0 \\
12.7\end{array}$ & $\begin{array}{l}10.1 \\
11.2\end{array}$ & $\begin{array}{r}8.6 \\
10.1\end{array}$ & $\begin{array}{l}5.1 \\
7.9\end{array}$ & $\begin{array}{l}4.3 \\
6.3\end{array}$ & $\begin{array}{l}3.9 \\
4.6\end{array}$ \\
\hline
\end{tabular}

Sources: Data provided by the Guinean authorities; and staff estimates.

1/ Comprise the Compagaie des Bauxiles de Guinée (CBG), Sociélté des Bauxites de Kindia (SBK--tormerly OBK), Friguia (alumina producer), Art́dor (diamond mine), and Société Aurifière de Guinée (gold mine--SAG). 
Table 17. Guinea: Direction of Trade--Exports, 1988-94 $y$

\begin{tabular}{|c|c|c|c|c|c|c|c|}
\hline & 1988 & 1989 & 1990 & 1991 & 1992 & 1993 & 1994 \\
\hline Industrial countries & $\underline{87.9}$ & $\underline{85.6}$ & $\underline{84.0}$ & $\underline{84.6}$ & $\underline{82.1}$ & $\underline{82.3}$ & $\underline{80.9}$ \\
\hline United States & 26.5 & 24.9 & 20.5 & 22.8 & 19.3 & 19.3 & 15.1 \\
\hline Belgium-Luxembourg & 9.3 & 9.4 & 10.7 & 11.6 & 152 & 24.4 & 26.7 \\
\hline Ireland & 11.0 & 9.3 & 112 & 11.5 & 12.1 & 9.9 & 10.0 \\
\hline Spain & 9.9 & 8.8 & 8.7 & 142 & 10.9 & 10.2 & 9.6 \\
\hline Fradce & 8.1 & 9.9 & 9.7 & 6.8 & 7.9 & 5.8 & 4.6 \\
\hline Italy & 6.8 & 6.3 & 5.0 & 4.8 & 5.8 & 3.3 & 3.5 \\
\hline Germany $2 /$ & 7.6 & 8.5 & 6.4 & 4.5 & 5.3 & 5.4 & 5.8 \\
\hline Norway & 1.8 & 1.5 & 4.0 & 3.5 & 3.4 & 1.2 & 1.1 \\
\hline Canada & 2.6 & 2.8 & 1.8 & 2.0 & 1.4 & 0.9 & 2.1 \\
\hline United Kingdom & 2.6 & 2.7 & 3.0 & 1.4 & 0.1 & 0.1 & 0.3 \\
\hline Austria & 0.4 & 0.4 & 0.4 & 0.4 & 0.5 & 0.6 & 0.4 \\
\hline Netheriands & 0.5 & 0.3 & 0.3 & 02 & 0.1 & 0.3 & 0.5 \\
\hline Japas & 02 & 0.5 & 1.1 & 0.2 & 0.1 & 0.6 & 12 \\
\hline Other industrial countries & 0.8 & 0.3 & 1.4 & 0.9 & 0.3 & 0.3 & 0.2 \\
\hline Developing countries & $\underline{12.1}$ & 14.4 & $\underline{16.0}$ & 15.4 & 17.9 & $\underline{17.7}$ & $\underline{19.1}$ \\
\hline Cameroon & 4.8 & 5.9 & 7.5 & 4.4 & 5.0 & 4.2 & 4.1 \\
\hline Brazil & -- & 0.3 & 0.6 & 4.3 & 5.1 & 4.8 & 5.4 \\
\hline Mali & 22 & 2.0 & 2.1 & 22 & 2.8 & -- & - \\
\hline Yugoalavia & 2.4 & 4.4 & 22 & 1.3 & 1.6 & $\ldots$ & $\ldots$ \\
\hline Cote d'lvoire & - & 0.4 & 0.5 & 0.9 & 1.1 & 102 & 1.3 \\
\hline India & 0.1 & 0.9 & 1.0 & 0.6 & 0.7 & 1.1 & 0.7 \\
\hline China, People's Republic & 0.1 & 0.1 & -- & 0.0 & 0.0 & 3.0 & 1.7 \\
\hline Hong Kong & -- & 0.0 & 0.0 & 0.1 & 0.4 & 0.6 & 0.8 \\
\hline Taiwan, Province of China & 0.1 & 02 & 02 & 0.3 & 0.6 & 0.5 & 0.2 \\
\hline Romania & 22 & 0.1 & - & 0.5 & 0.1 & 0.1 & 0.7 \\
\hline Other developing countries & 0.2 & 0.2 & 1.8 & 0.7 & 0.4 & 2.2 & 42 \\
\hline \multicolumn{8}{|l|}{ Memorandum items: } \\
\hline \multirow{3}{*}{$\begin{array}{l}\text { Total DOTS exports } \\
\text { Is millions of U.S. dollars } \\
\text { is perceat of Guinea's } \\
\text { wotal exports }\end{array}$} & & & & & & & \\
\hline & 477.3 & 5872 & 626.9 & 666.4 & $\$ 90.0$ & 698.8 & 716.6 \\
\hline & 78.4 & 80.3 & 76.8 & 84.3 & 89.8 & 105.1 & 114.5 \\
\hline
\end{tabular}

Source: IMF, Direction of Tnde Stutistia (DOTS).

1/ Data compiled on the basis of reporting by Guinea's trading partaen; excludes noureporting countries (nowbly the former Soviet Union). 
Table 18. Guinea: Direction of Trade--Imports, 1988-94 $1 /$

\begin{tabular}{|c|c|c|c|c|c|c|c|}
\hline & 1988 & 1989 & 1990 & 1991 & 1992 & 1993 & 1994 \\
\hline Industrial countries & $\underline{86.4}$ & $\underline{772}$ & $\underline{76.1}$ & $\underline{72.9}$ & $\underline{66.9}$ & $\underline{56.3}$ & $\underline{60.6}$ \\
\hline $\begin{array}{l}\text { France } \\
\text { United States } \\
\text { Belgium-Lurembourg } \\
\text { Netherlands } \\
\text { Italy } \\
\text { Germany } 2 / \\
\text { Japan } \\
\text { Spain } \\
\text { United Kingdom } \\
\text { Switzerland } \\
\text { Greece } \\
\text { Sweden } \\
\text { Denmark } \\
\text { Canada } \\
\text { Ireland } \\
\text { Austria } \\
\text { Otber industrial countries }\end{array}$ & $\begin{array}{r}35.7 \\
8.8 \\
9.0 \\
4.8 \\
6.3 \\
5.5 \\
2.6 \\
3.8 \\
4.6 \\
0.8 \\
0.1 \\
0.8 \\
0.2 \\
1.8 \\
0.4 \\
0.5 \\
0.7\end{array}$ & $\begin{array}{r}30.3 \\
9.0 \\
7.9 \\
3.4 \\
7.3 \\
6.1 \\
1.8 \\
2.0 \\
5.1 \\
0.4 \\
1.1 \\
0.3 \\
0.2 \\
0.9 \\
0.1 \\
0.1 \\
1.1\end{array}$ & $\begin{array}{r}30.5 \\
7.9 \\
7.4 \\
3.7 \\
4.0 \\
5.3 \\
3.5 \\
4.3 \\
3.7 \\
0.8 \\
0.9 \\
0.4 \\
0.2 \\
1.1 \\
0.1 \\
0.3 \\
1.9\end{array}$ & $\begin{array}{r}24.9 \\
14.0 \\
5.8 \\
4.9 \\
4.1 \\
5.6 \\
3.7 \\
4.3 \\
2.2 \\
0.6 \\
0.8 \\
0.3 \\
0.2 \\
0.3 \\
0.2 \\
0.3 \\
0.6\end{array}$ & $\begin{array}{r}28.7 \\
8.6 \\
6.0 \\
4.6 \\
4.4 \\
3.8 \\
3.3 \\
2.5 \\
2.0 \\
0.9 \\
0.8 \\
0.3 \\
0.3 \\
0.2 \\
0.1 \\
0.3 \\
0.3\end{array}$ & $\begin{array}{r}19.4 \\
8.2 \\
6.1 \\
4.3 \\
4.5 \\
2.6 \\
2.8 \\
3.8 \\
2.3 \\
0.3 \\
0.3 \\
0.2 \\
0.2 \\
0.3 \\
0.2 \\
0.3 \\
0.4\end{array}$ & $\begin{array}{r}19.5 \\
7.1 \\
6.9 \\
3.8 \\
3.3 \\
4.0 \\
3.4 \\
3.5 \\
4.9 \\
1.0 \\
0.2 \\
0.2 \\
0.2 \\
0.3 \\
0.2 \\
1.5 \\
0.6\end{array}$ \\
\hline Developing countries & $\underline{13.6}$ & $\underline{22.8}$ & $\underline{23.9}$ & $\underline{\underline{27.1}}$ & $\underline{33.1}$ & $\underline{43.7}$ & $\underline{39.4}$ \\
\hline $\begin{array}{l}\text { Cóte d'Ivoire } \\
\text { Hong Kong } \\
\text { China } \\
\text { Brazil } \\
\text { Taiwan, Province of China } \\
\text { Singapore } \\
\text { Morocco } \\
\text { Pakistan } \\
\text { Korea } \\
\text { Senegal } \\
\text { Cameroon } \\
\text { Nigeria } \\
\text { Romania } \\
\text { Other developing countries }\end{array}$ & $\begin{array}{l}-- \\
2.2 \\
1.6 \\
1.6 \\
1.5 \\
1.1 \\
-- \\
0.8 \\
1.6 \\
0.3 \\
0.6 \\
0.2 \\
2.0\end{array}$ & $\begin{array}{r}7.4 \\
1.6 \\
1.5 \\
2.9 \\
0.9 \\
1.0 \\
1.0 \\
0.4 \\
1.6 \\
0.3 \\
0.3 \\
-5 \\
5.0\end{array}$ & $\begin{array}{r}10.6 \\
3.8 \\
1.8 \\
1.6 \\
1.0 \\
1.1 \\
0.3 \\
0.3 \\
1.5 \\
0.3 \\
1.2 \\
-- \\
0.5\end{array}$ & $\begin{array}{r}12.0 \\
5.7 \\
2.1 \\
0.9 \\
1.3 \\
1.0 \\
0.7 \\
0.6 \\
1.4 \\
0.1 \\
\ldots \\
1.4\end{array}$ & $\begin{array}{r}11.8 \\
8.2 \\
4.4 \\
1.8 \\
1.3 \\
1.0 \\
1.0 \\
1.0 \\
0.4 \\
0.2 \\
0.1 \\
2.2 \\
0.1 \\
0.6\end{array}$ & $\begin{array}{r}13.6 \\
6.8 \\
4.4 \\
2.0 \\
1.0 \\
4.1 \\
0.9 \\
0.3 \\
-- \\
2.5 \\
0.1 \\
2.3 \\
0.0 \\
5.6\end{array}$ & $\begin{array}{r}16.0 \\
6.3 \\
3.8 \\
2.4 \\
1.0 \\
1.0 \\
0.3 \\
-5 \\
2.9 \\
0.1 \\
2.5 \\
0.1 \\
3.1\end{array}$ \\
\hline \multicolumn{8}{|l|}{ Memorendum ilems: } \\
\hline $\begin{array}{l}\text { Total DOTS imports } \\
\text { In millions of U.S. dollans } \\
\text { In percent of Guinea's } \\
\text { total imports }\end{array}$ & $\begin{array}{r}432.9 \\
71.7\end{array}$ & $\begin{array}{r}490.1 \\
83.5\end{array}$ & $\begin{array}{r}594.3 \\
822\end{array}$ & $\begin{array}{r}694.6 \\
945\end{array}$ & $\begin{array}{c}775.4 \\
1048\end{array}$ & $\begin{array}{l}775.4 \\
106.1\end{array}$ & $\begin{array}{l}775.4 \\
112.9\end{array}$ \\
\hline
\end{tabular}

Source: IMF. Direction of Trnde Sutistica (DOTS).

1/ Data compiled on the basis of reporting by Guines's trading partners; excludes noareporting countries (notably the former Soviet Union).

2f Through mid-1990, covers the area of the former Federal Republic of Germany only. 
Table 19. Guinea: External Public Debt, 1988-94

\begin{tabular}{|c|c|c|c|c|c|c|c|}
\hline & 1988 & 1989 & 1990 & 1991 & 1992 & 1993 & $\frac{1994}{\text { Est. }}$ \\
\hline & \multicolumn{7}{|c|}{ (In millions of U.S. dollars, end of period) } \\
\hline \multicolumn{8}{|l|}{$\begin{array}{l}\text { Total medium - and long - term } \\
\text { debt outstanding }\end{array}$} \\
\hline $\begin{array}{l}\text { Medium - and long-term debt, } \\
\text { excluding IMF }\end{array}$ & $\underline{2,026.2}$ & $\underline{1,9632}$ & $\underline{2,0720}$ & $\underline{2,345.6}$ & $\underline{2,411.0}$ & 2.533 .1 & $\underline{2,7383}$ \\
\hline Multilateral institutions & 470.4 & 562.9 & 583.9 & 744.8 & 779.2 & 1110.9 & 1207.4 \\
\hline Paris Club & 704.8 & 5572 & 633.6 & 754.9 & 781.0 & 751.2 & 809.0 \\
\hline Rescheduled in 1986 & 256.8 & 253.6 & 246.7 & 269.1 & 145.4 & 205.7 & 208.2 \\
\hline Rescheduled in 1989 & -- & 62.4 & 116.9 & 104.8 & 104.8 & 106.3 & 110.1 \\
\hline Rescheduled in 1992 & -- & -- & -- & - & 154.1 & 138.8 & 140.8 \\
\hline Other & 448.0 & 241.2 & 270.0 & 381.1 & 376.7 & 300.4 & 349.8 \\
\hline Other bilateral creditors & 278.3 & 277.8 & 275.6 & 262.3 & 262.1 & 336.3 & 363.1 \\
\hline Organizations of Arab countries & 43.2 & 58.6 & 52.6 & 66.9 & 642 & 54.7 & 59.8 \\
\hline Commercial banks & 35.5 & 30.2 & 26.7 & 21.0 & 21.0 & 16.4 & 15.2 \\
\hline Suppliers' credits & 51.7 & 442 & 34.4 & 43.7 & 40.5 & 32.1 & 20.1 \\
\hline Former Soviet Union $1 / 2 /$ & 442.3 & 432.2 & 4652 & 452.0 & 463.0 & 231.5 & 231.5 \\
\hline Outstanding IMF credit & 48.6 & $\underline{61.3}$ & $\underline{51.5}$ & $\underline{54.9}$ & $\underline{63.7}$ & $\underline{60.4}$ & $\underline{71.0}$ \\
\hline General resources & $\overline{28.3}$ & $\overline{22.2}$ & $\overline{10.1}$ & 1.1 & -- & $\overline{--}$ & $=$ \\
\hline SAF/ESAF loans & 15.6 & 38.0 & 412 & 53.8 & 63.7 & 60.4 & 71.0 \\
\hline Trust Fund & 4.7 & 1.1 & 0.1 & -- & -- & -- & - \\
\hline Memorandum items: & \multicolumn{7}{|c|}{ (In percent of GDP) } \\
\hline $\begin{array}{l}\text { Total debt } \\
\text { Medium - and long - term debt }\end{array}$ & 87.0 & 832 & 75.3 & 80.5 & 83.2 & 81.7 & 82.8 \\
\hline excluding IMF & 85.0 & 80.7 & 73.5 & 78.7 & 81.1 & 79.8 & 80.7 \\
\hline IMF credit & 2.0 & 2.5 & 1.8 & 18 & 2.1 & 1.9 & 2.1 \\
\hline
\end{tabular}

Sources: Data provided by the Guinean authorities; and staft estimates.

$1 /$ Based on an accounting exchange rate of rub 0.557 per U.S. dollar.

2/ It is assumed that debt to the FSU was in arrears at end-1992, and thus reschedulable on terms at least comparable to those of the Paris Cub rescheduling of November 1992 
Table 20. Guinea: External Debt Service, 1988-94 1/

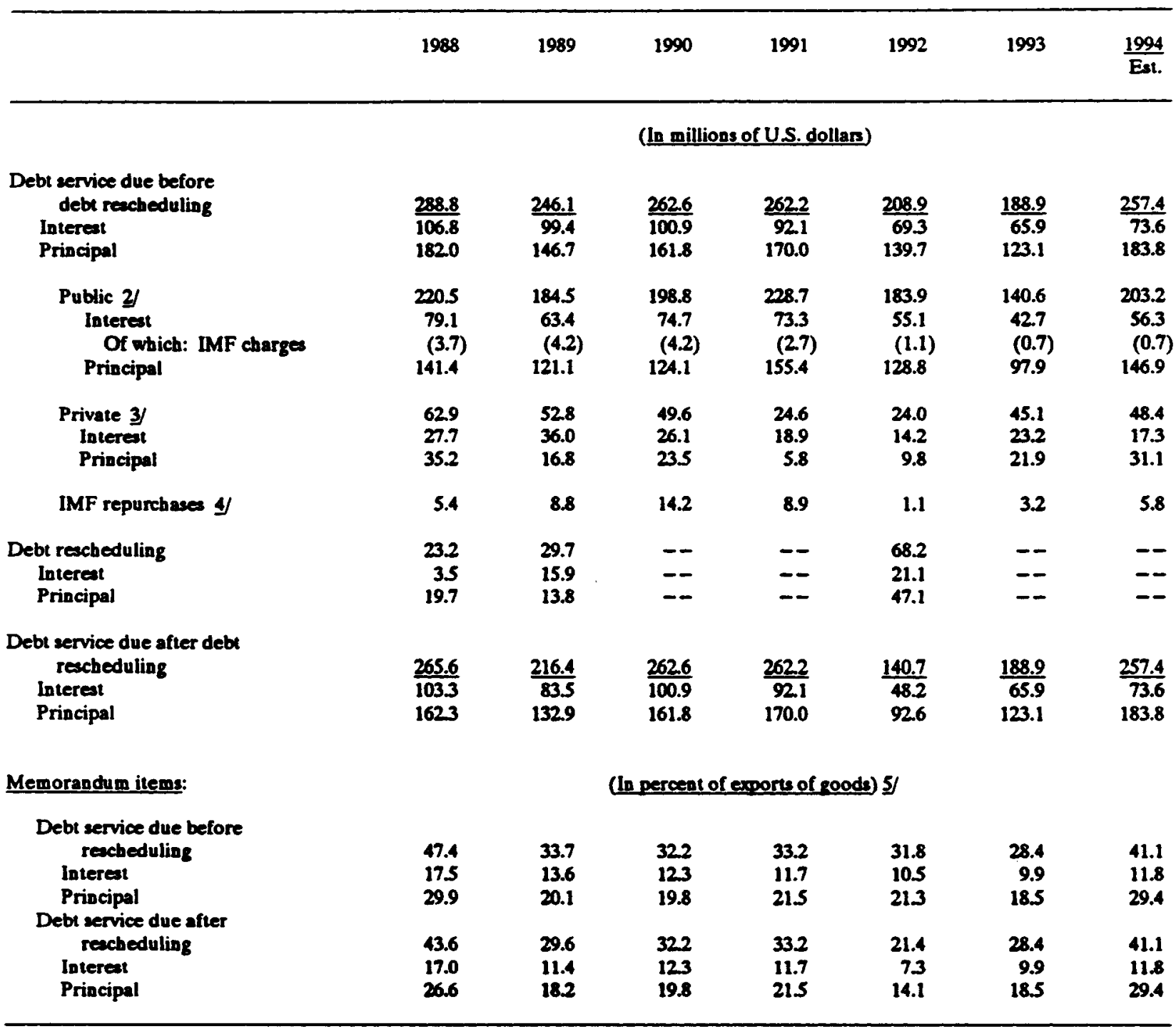

Soures: Data provided by the Guinean authorities; and atsf eatimates.

1/ Including transactions with the former Soviet Uoion.

2/ Government and public enterprive.

3/ Mainly mining companies.

4) Including IMF Truat Fusd.

5/ Export earnings include gold exports by the Central Bank of Guivea. 
Table 21. Guinea: Debt Service Limbilities on Medium - and Long -Term External Public Deb1, 1988-98

(In millions of U.S. dollhrs)

\begin{tabular}{|c|c|c|c|c|c|c|c|c|c|c|c|}
\hline & 1988 & 1989 & 1990 & 1991 & 1992 & 1993 & 1994 & \multicolumn{4}{|c|}{ Scheduled debt service } \\
\hline $\begin{array}{l}\text { Total debt service due } \\
\text { (excluding IMP) }\end{array}$ & 216.8 & 180.3 & 194.6 & 226.0 & 182.8 & 139.9 & 202.5 & 139.9 & 145.2 & 123.2 & 128.2 \\
\hline 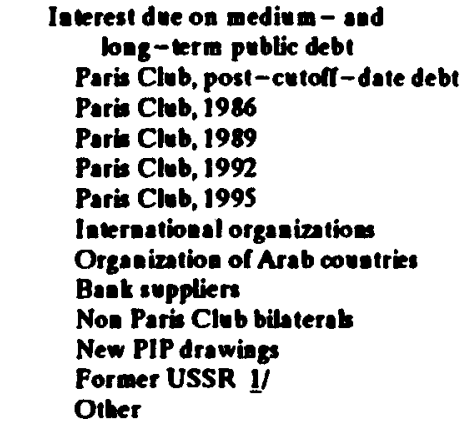 & $\begin{array}{r}75.4 \\
13.8 \\
31.5 \\
--- \\
-- \\
\ldots .9 \\
9.9 \\
1.7 \\
6.3 \\
2.2 \\
-\overline{10.0} \\
--\end{array}$ & $\begin{array}{r}59.2 \\
7.8 \\
18.8 \\
4.1 \\
-- \\
1.7 \\
10.7 \\
1.0 \\
3.1 \\
2.3 \\
9.6 \\
1.8\end{array}$ & $\begin{array}{r}70.6 \\
5.9 \\
23.7 \\
13.7 \\
-\ldots \\
11.2 \\
1.2 \\
3.2 \\
1.9 \\
-9.7 \\
9.7 \\
0.1\end{array}$ & $\begin{array}{r}70.6 \\
9.0 \\
20.3 \\
12.0 \\
-- \\
\ldots \\
12.6 \\
1.1 \\
1.7 \\
1.2 \\
12.1 \\
0.6\end{array}$ & $\begin{array}{r}54.0 \\
7.9 \\
16.2 \\
8.1 \\
-- \\
\ldots \\
14.6 \\
1.5 \\
1.3 \\
0.9 \\
3.0 \\
0.6\end{array}$ & $\begin{array}{r}42.0 \\
5.7 \\
11.5 \\
7.2 \\
4.0 \\
\ldots . . \\
10.6 \\
0.8 \\
1.2 \\
0.6 \\
- \\
0.3\end{array}$ & $\begin{array}{r}55.6 \\
6.4 \\
8.1 \\
9.1 \\
8.7 \\
13.2 \\
15 \\
1.1 \\
1.8 \\
0.4 \\
4.3 \\
0.5 \\
\end{array}$ & $\begin{array}{r}44.8 \\
7.6 \\
3.3 \\
7.7 \\
6.6 \\
-\overline{17.1} \\
1.1 \\
0.6 \\
0.1 \\
-- \\
0.8\end{array}$ & $\begin{array}{r}48.6 \\
7.0 \\
2.6 \\
7.7 \\
6.2 \\
2.3 \\
15.8 \\
1.0 \\
0.2 \\
0.1 \\
4.7 \\
0.9\end{array}$ & $\begin{array}{r}49.9 \\
6.9 \\
1.8 \\
7.5 \\
6.0 \\
1.7 \\
15.0 \\
0.9 \\
1.2 \\
8.3 \\
1.4\end{array}$ & $\begin{array}{r}52.2 \\
6.8 \\
1.5 \\
6.8 \\
6.0 \\
1.7 \\
14.4 \\
0.8 \\
-\overline{0.1} \\
12.5 \\
-1.7\end{array}$ \\
\hline 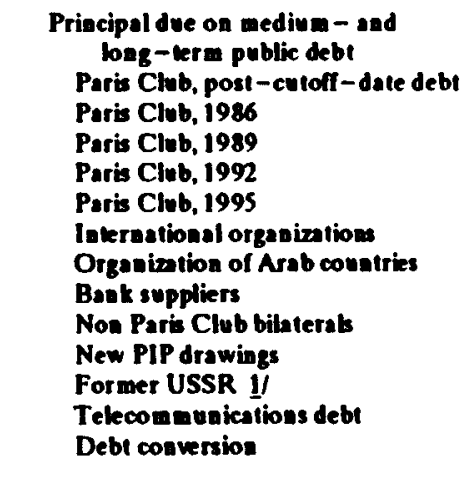 & $\begin{array}{r}141.4 \\
26.6 \\
5.3 \\
-- \\
-- \\
20.8 \\
9.3 \\
33.4 \\
18.3 \\
-\overline{27.7} \\
-- \\
--\end{array}$ & $\begin{array}{r}121.1 \\
13.0 \\
3.0 \\
2.1 \\
-- \\
19 . \\
19.4 \\
41.5 \\
11.1 \\
21.1 \\
-.- \\
46.9 \\
-.- \\
--\end{array}$ & $\begin{array}{r}124.1 \\
13.8 \\
20.6 \\
1.7 \\
-- \\
2.2 \\
2.2 \\
4.9 \\
14.8 \\
15.9 \\
-\overline{30.2} \\
-- \\
--\end{array}$ & $\begin{array}{r}155.4 \\
13.9 \\
42.8 \\
2.3 \\
-- \\
24.5 \\
3.7 \\
14.3 \\
17.3 \\
-- \\
36.7 \\
-- \\
--\end{array}$ & $\begin{array}{r}128.8 \\
11.1 \\
58.9 \\
-- \\
-- \\
26.9 \\
4.5 \\
15.6 \\
4.6 \\
-\overline{6.8} \\
\overline{0.6}\end{array}$ & $\begin{array}{r}97.9 \\
2.5 \\
57.3 \\
\overline{2.7} \\
11.0 \\
3.8 \\
7.0 \\
7.0 \\
-- \\
-- \\
\overline{3.8}\end{array}$ & $\begin{array}{r}146.9 \\
3.2 \\
56.4 \\
4.3 \\
\ldots . \\
20.0 \\
5.5 \\
15.4 \\
5.9 \\
-- \\
-- \\
32.4 \\
3.9\end{array}$ & $\begin{array}{r}95.1 \\
1.4 \\
40.7 \\
-\overline{3.9} \\
--\overline{1} \\
19.3 \\
5.0 \\
13.0 \\
8.8 \\
-- \\
-- \\
-- \\
--\end{array}$ & $\begin{array}{r}96.7 \\
3.2 \\
20.3 \\
2.1 \\
4.0 \\
1.5 \\
19.9 \\
5.0 \\
14.2 \\
10.2 \\
-- \\
-- \\
16.2 \\
--\end{array}$ & $\begin{array}{r}73.3 \\
6.5 \\
10.2 \\
8.6 \\
2.1 \\
2.3 \\
21.3 \\
5.5 \\
2.6 \\
10.3 \\
-- \\
-- \\
4.1 \\
--\end{array}$ & $\begin{array}{r}76.0 \\
8.8 \\
6.9 \\
13.0 \\
1.5 \\
2.3 \\
22.2 \\
5.9 \\
-- \\
11.3 \\
-- \\
-- \\
4.1 \\
--\end{array}$ \\
\hline Memorandum items: & & & & & & & & & & & \\
\hline $\begin{array}{l}\text { Oross accumulatios of debl } \\
\text { service paymeats arrean } \\
\text { Incerest } \\
\text { Principal }\end{array}$ & $\begin{array}{l}96.5 \\
29.0 \\
67.6\end{array}$ & $\begin{array}{r}38.6 \\
8.0 \\
30.6\end{array}$ & $\begin{array}{r}109.5 \\
50.7 \\
58.8\end{array}$ & $\begin{array}{r}112.9 \\
29.2 \\
83.8\end{array}$ & $\begin{array}{l}=- \\
=-\end{array}$ & $\begin{array}{r}68.8 \\
4.7 \\
64.1\end{array}$ & $\begin{array}{r}117.8 \\
14.3 \\
103.5\end{array}$ & $\begin{array}{l}-- \\
--\end{array}$ & $\begin{array}{l}-- \\
-- \\
--\end{array}$ & $\begin{array}{l}-- \\
-- \\
--\end{array}$ & $\begin{array}{l}-- \\
=-\end{array}$ \\
\hline
\end{tabular}

Sources: Data provided by the Guinesa authorities; and staff estimates.

1/ Estimates. Until mid-1992, Guines's debt service payments to the former Soviet Union (FSU) were settled in tind, through a compensation mechanism with bauxite exports; Guinea's bilateral trade arsangement with the FSU was discontiaued in mid -1992. 
Table 22. Guinea: Nominal Erchange Rates and Effective Exchange Rate lndices, 1988-95

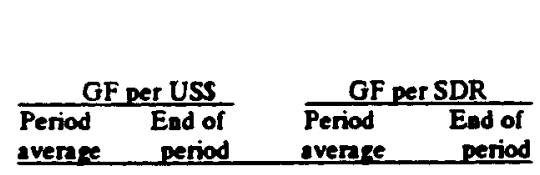

(In Guinean francs per curreacy unit)

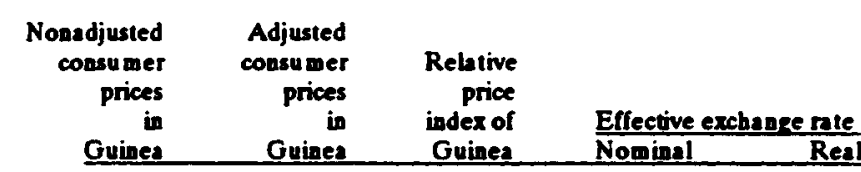

(Period averare indices, $1990=100)$

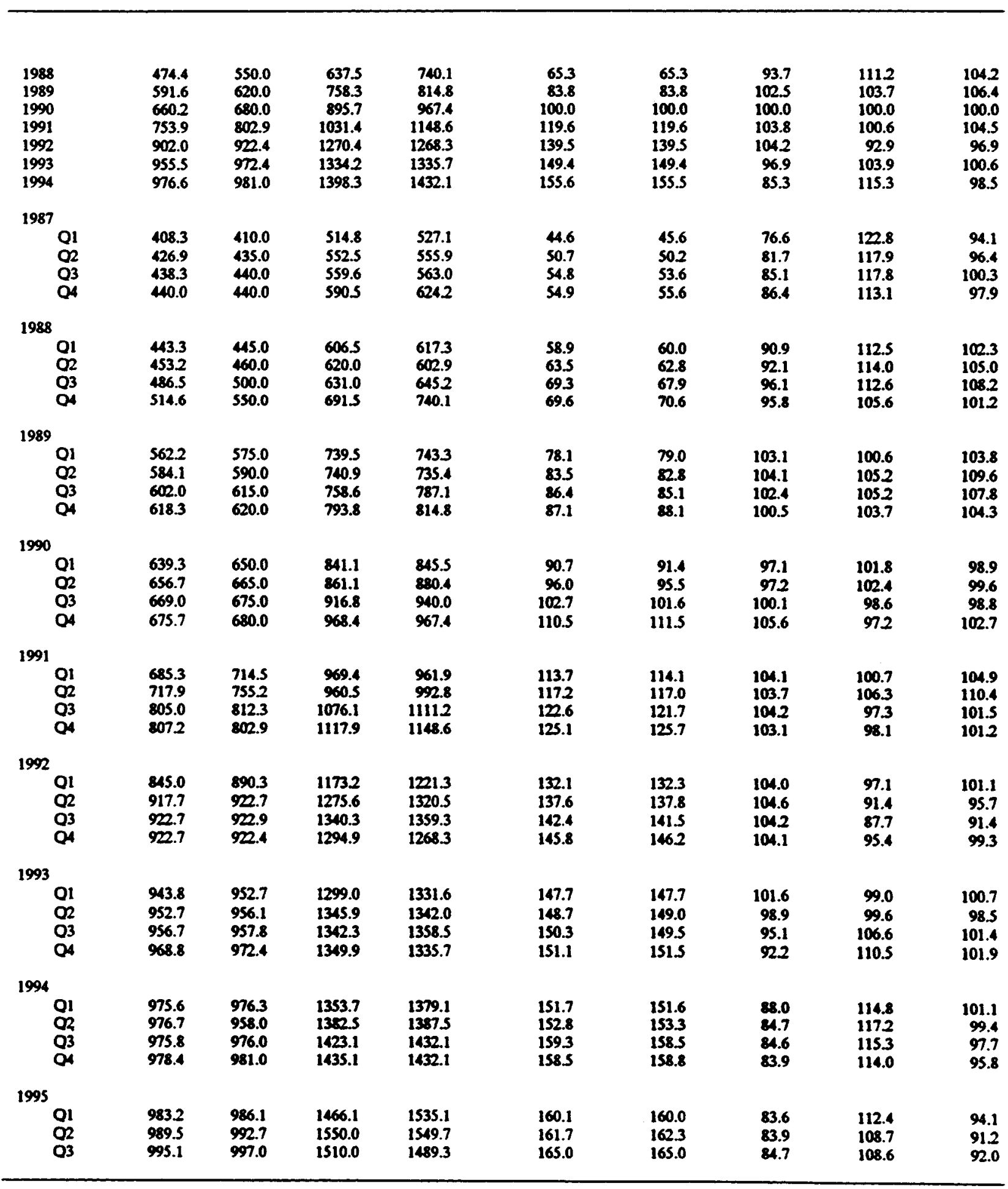

Sources: Data provided by the Guinesn authorities; IMF, lnternational Financial Statisties and Information Notice System; and suff estimates. 